\title{
Conforto Térmico e a Prática do Projeto de Edificações: recomendações para Ribeirão Preto
}

Dissertação apresentada à Escola de Engenharia de São Carlos da Universidade de São Paulo como parte dos requisitos para obtenção do título de mestre em Arquitetura e Urbanismo.

Área de Concentração: Arquitetura, Urbanismo e Tecnologia.

Orientadora: Profa. Assoc. Rosana Maria Caram

São Carlos, SP. 


\section{FOLHA DE JULGAMENTO}

Candidata: Arquiteta e Urbanista LUCIANA PAGNANO RIBEIRO

Dissertação defendida e julgada em 13/11/2008 perante a Comissão Julgadora:

Prof ${ }^{\text {. }}$ Associada ROSANA MARIA CARAM (Orientadora)

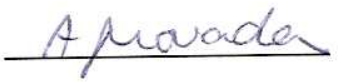

(Escola de Engenharia de São Carlos/USP)

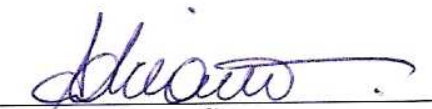

Prof. Dr. JOÃO ADRIANO ROSSIGNOLO

APRONADA
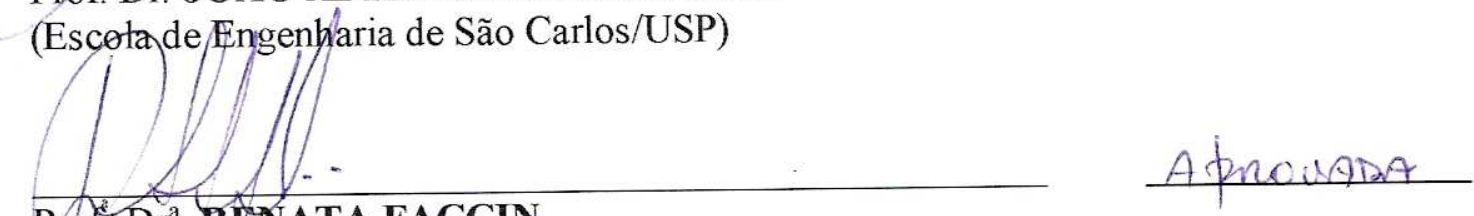

PrO $\mathrm{Dr}^{\mathrm{a}}$ RENATA FACCIN

(UNAR - Centro Universitário Edmundo Ulson)

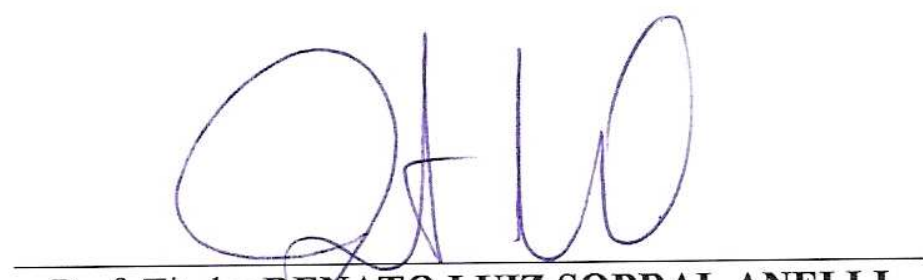

Prof. Titular REXATO LUIZ SOBRAL ANELLI

Coordenador do Programa de Pós-Graduação em Arquitetura e Urbanismo

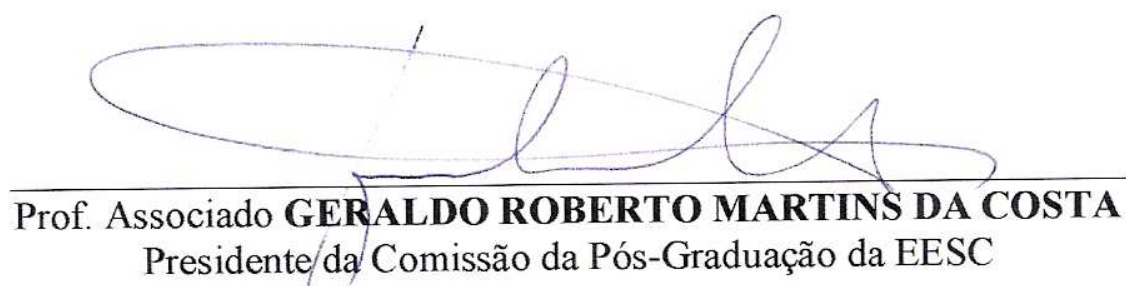


Ao meu amor Achiles, por toda sua paciência, compreensão, apoio e companheirismo especial. Ao nosso filho Pedro, presente $24 \mathrm{hs}$, participando 'intrauterinamente' do desenvolvimento desta dissertação. 



\section{AGRADECIMENTOS}

À Profa Rosana Caram, pela orientação, incentivo e confiança durante a pesquisa.

Ao Prof. Francisco Vecchia, pela contribuição na pesquisa e pela sua disposição para conversas e esclarecimentos.

À Prof ${ }^{a}$ Renata Facin e ao Prof. João Adriano Rossignolo, pelas contribuições dadas no exame de qualificação.

Ao Renato Zorzenon e Gustavo Caminitti, pela disponibilização dos dados da estação meteorológica da UNAERP - Universidade de Ribeirão Preto.

À Denise do IAC - Instituto Agronômico -, pela disponibilização dos dados da estação meteorológica deste instituto na Estação Experimental em Ribeirão Preto.

À minha mãe Marta, pelo apoio financeiro durante a pesquisa.

Ao meu irmão Lucas, pelo auxílio na revisão de texto. 



\section{RESUMO}

RIBEIRO, L.P. (2008) Conforto Térmico e a Prática do Projeto de Edificações: recomendações para Ribeirão Preto. Dissertação (Mestrado) - Escola de Engenharia de São Carlos, Universidade de São Paulo, São Carlos, 2008.

Em virtude do rigoroso clima quente da cidade de Ribeirão Preto, a questão do conforto térmico assume destacada relevância no projeto de edificações. Porém, como em outros locais, os significativos avanços nas pesquisas em conforto térmico no ambiente construído não têm se refletido na prática do projeto de edificações na cidade. Assim, o objetivo deste trabalho é gerar um conjunto de recomendações de projeto para edificações em Ribeirão Preto, sob a ótica do conforto térmico. São recomendações gerais e de fácil aplicação, voltadas às primeiras fases do processo de projeto, e que buscam uma maior aproximação dos profissionais projetistas com os conceitos de conforto térmico no ambiente construído. Para a elaboração deste conjunto de recomendações, utilizou-se como parâmetro um método e uma norma existentes, além de uma detalhada análise dos componentes e particularidades climáticas locais.

Palavras-chave: conforto térmico; Ribeirão Preto; recomendações de projeto; edificações. 


\section{ABSTRACT}

RIBEIRO, L.P. (2008) Thermal Comfort and the Practice of Building Design: recommendations for Ribeirao Preto. Dissertação (Mestrado) - Escola de Engenharia de São Carlos, Universidade de São Paulo, São Carlos, 2008.

Towards the high temperatures the city of Ribeirão Preto presents, the thermal comfort became a very important issue in the building design. However, as at other locations, the significant progress of research in thermal comfort in the internal environment does not have been reflected in the practicing professional in the city. The objective of this work is to deliver some recommendations for design building in Ribeirão Preto, under the thermal comfort concept. These are general recommendations and easy to be used, focused at the first project phases, reaching the professionals with the concepts of thermal comfort in the internal environment. For these recommendations, were used as a method a parameter and a standard and a detailed analysis of existing components and features local climate.

Keywords: thermal comfort; Ribeirão Preto; recommendations; design building. 


\section{SUMARIO}

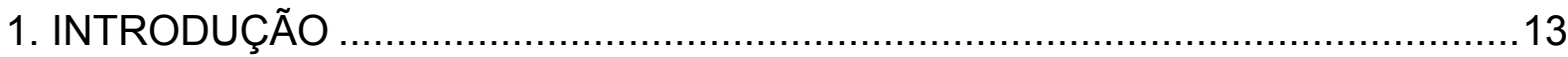

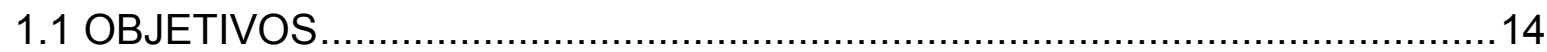

2. CLIMA: CONCEITOS E CLASSIFICAÇÕES ………......................................15

3. INFLUÊNCIA DO CLIMA EM EDIFICAÇÕES …...............................................21

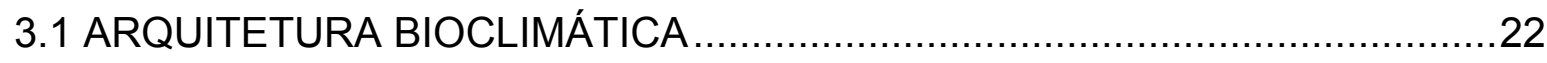

3.2 CONFORTO TÉRMICO E AMBIENTE CONSTRUÍDO …..............................25

3.3 CONDICIONAMENTO TÉRMICO NATURAL E CONSUMO ENERGÉTICO EM

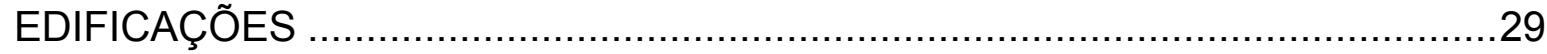

3.4 CONFORTO TÉRMICO EM EDIFICAÇÕES NO BRASIL ……......................32

3.4.1 Hospital Rede Sarah de Fortaleza - CE ............................................... 34

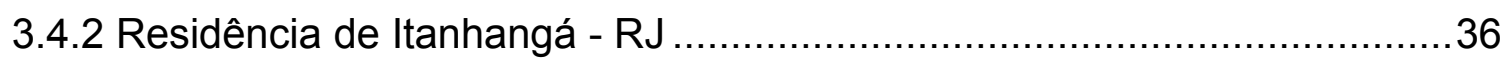

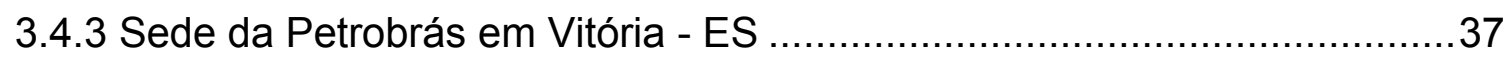

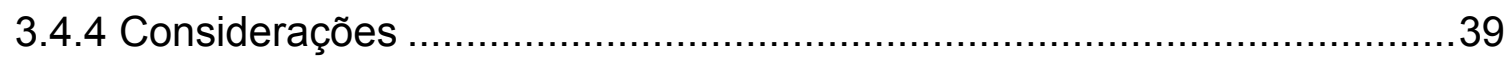

4. A PRÁTICA DO PROJETO ARQUITETÔNICO ……........................................

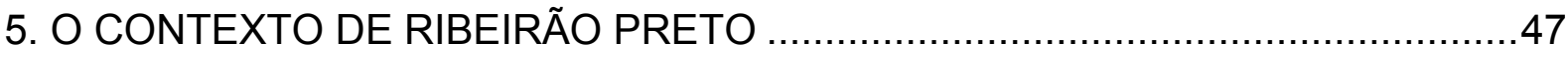

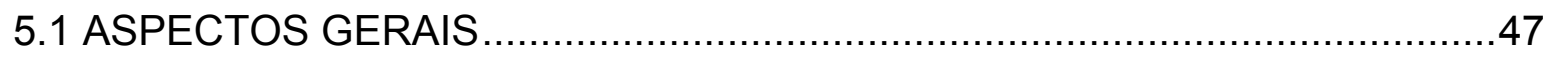

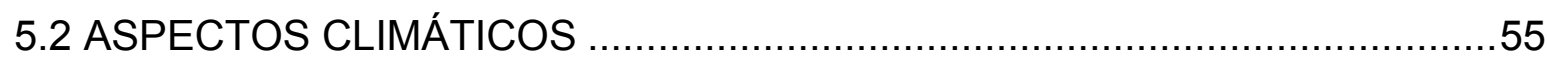

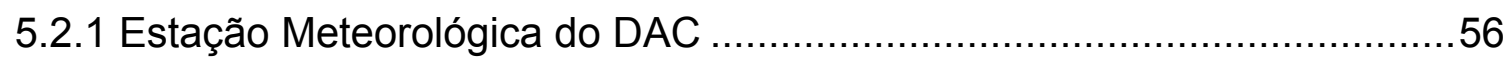

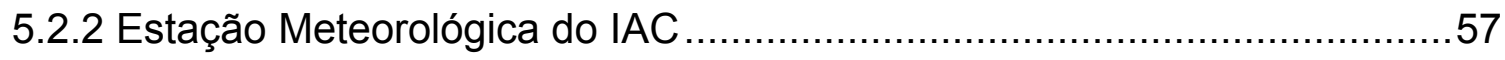

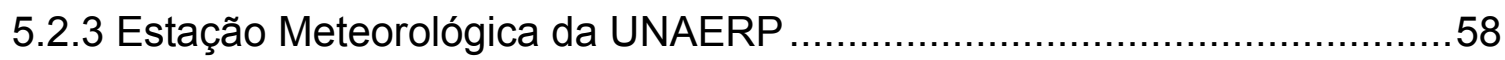

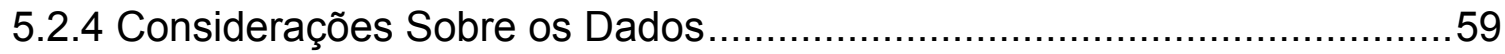

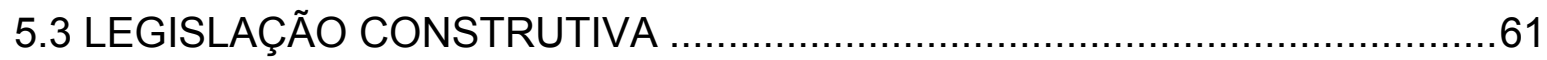

5.4 EDIFICAÇÕES E CONFORTO TÉRMICO NA CIDADE ................................64

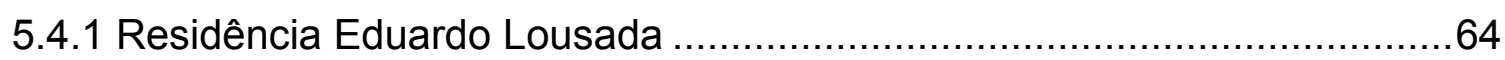

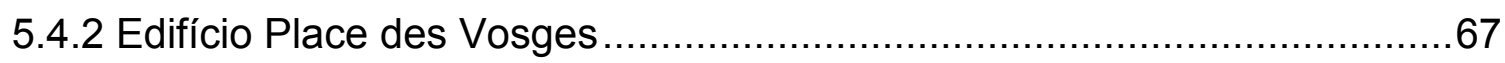

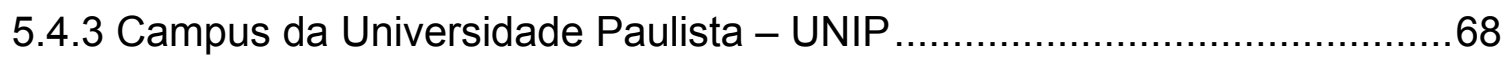

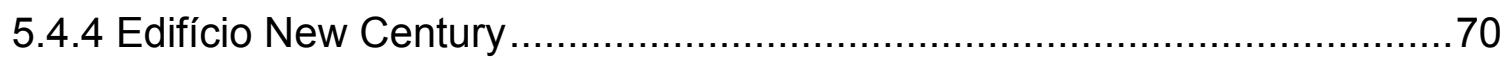

5.4.5 Sede Casa Cor Interior 2006 ...................................................... 71 
5.4.6 Residência Royal Park ………...........................................................

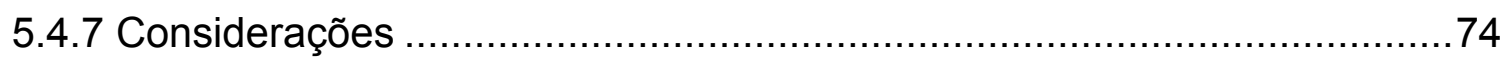

5.5 MATERIAIS E SISTEMAS CONSTRUTIVOS ........................................... 75

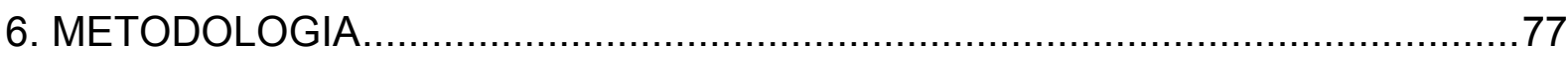

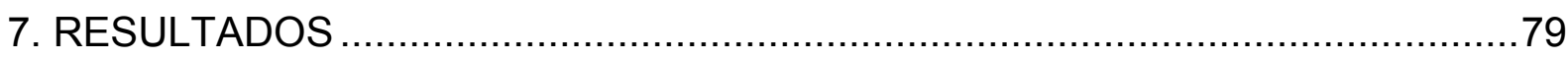

7.1 PARTICULARIDADES DO CLIMA EM RIBEIRÃO PRETO …......................79

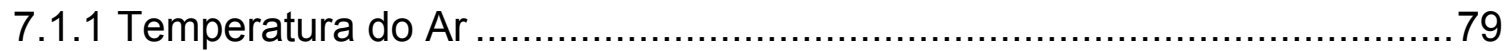

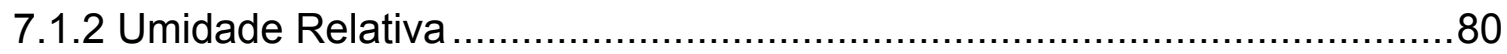

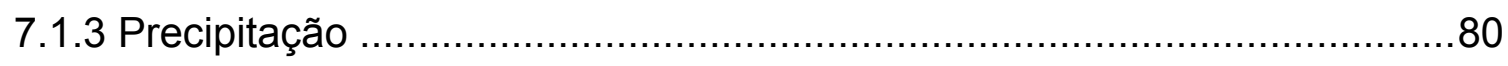

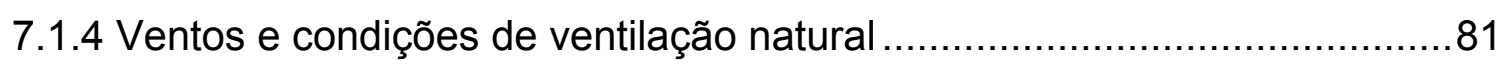

7.2 ANÁLISE DA INCIDÊNCIA DE RADIAÇÃO SOLAR ….............................. 81

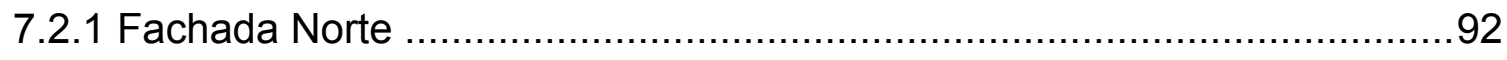

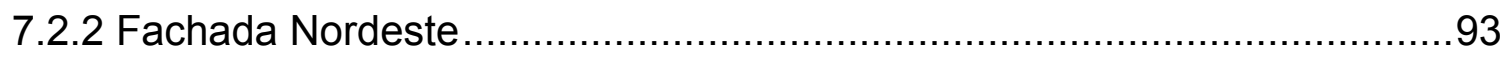

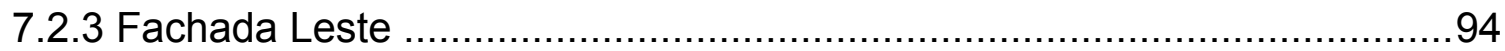

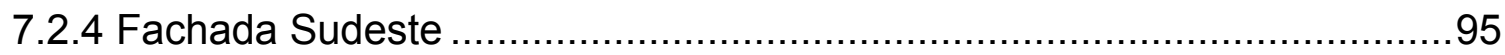

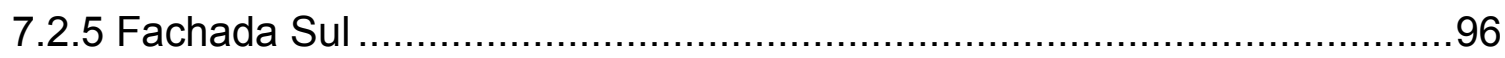

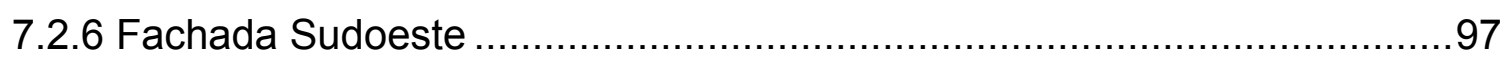

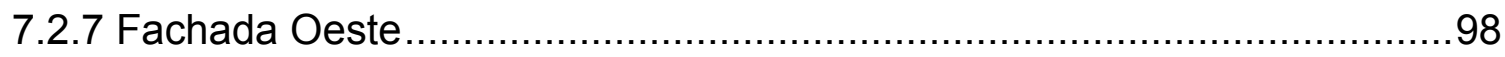

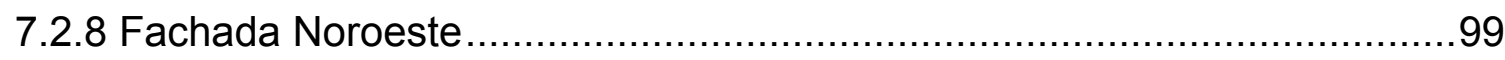

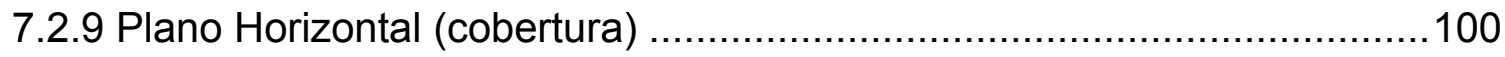

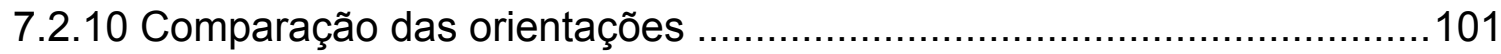

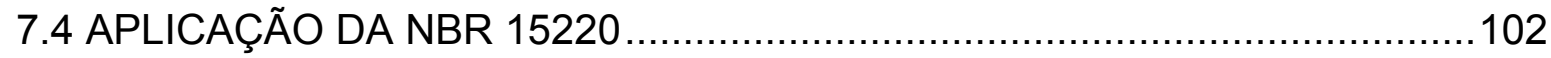

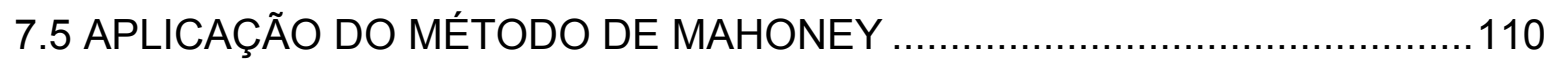

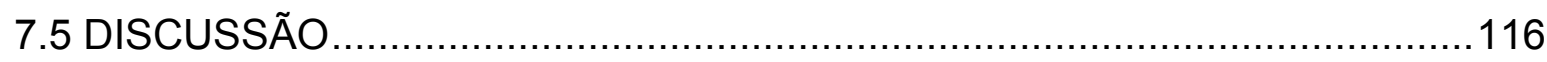

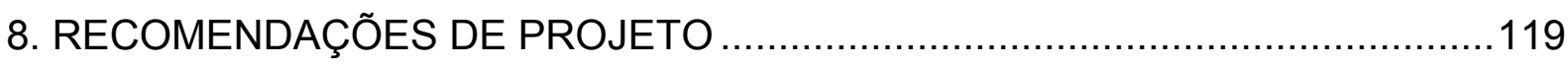

8.1 IMPLANTAÇÃO, DISTRIBUIÇÃO E FORMA DO EDIFÍCIO.........................119

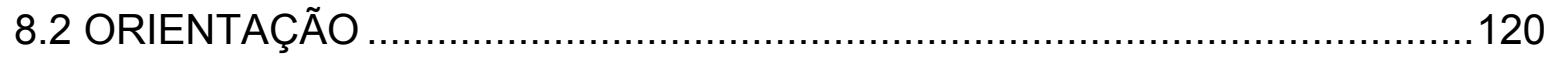

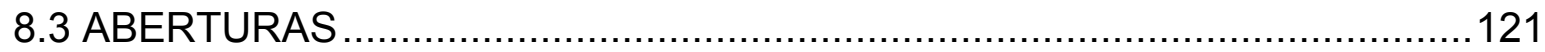

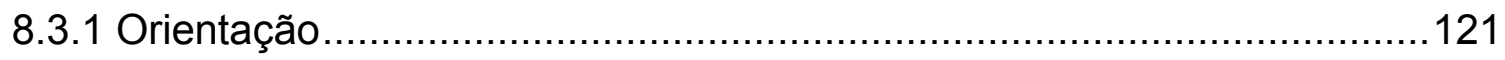

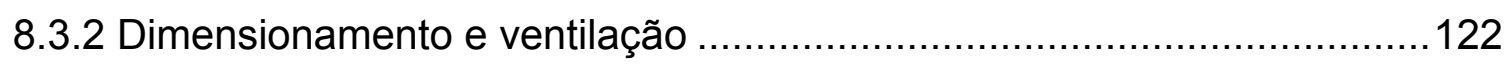

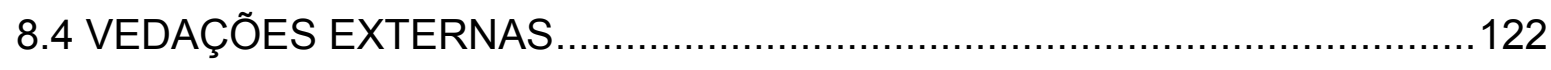

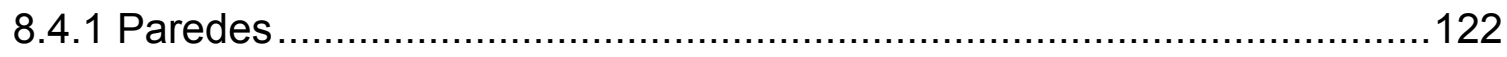

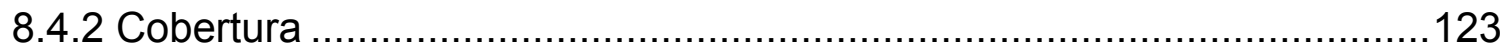


8.4.3 Superfícies envidraçadas e transparentes ………............................125

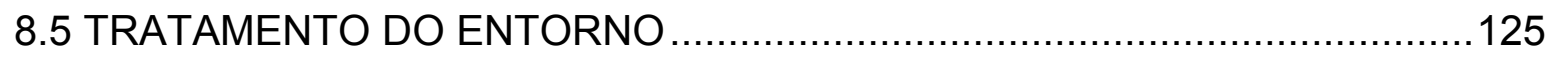

8.6 ESTRATÉGIAS DE CONDICIONAMENTO TÉRMICO PASSIVO .................126

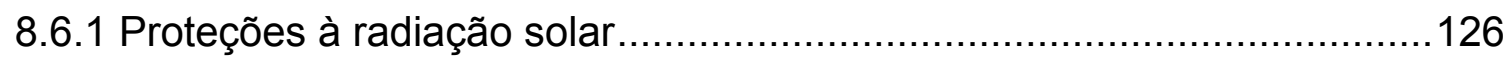

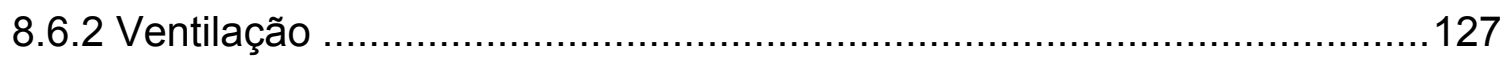

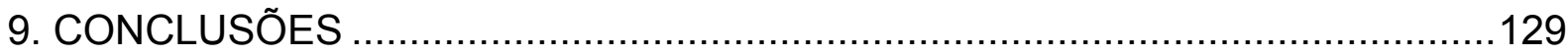

9.1 SUGESTÕES PARA PESQUISAS FUTURAS …...................................130

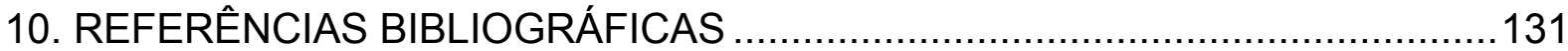

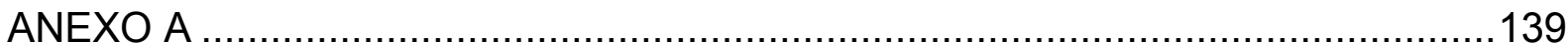

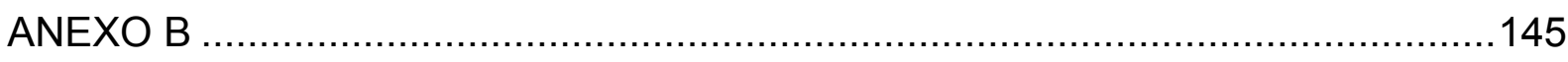

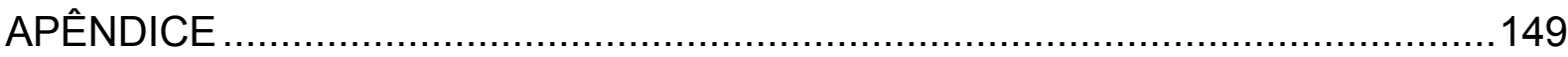





\section{INTRODUÇÃO}

A cidade de Ribeirão Preto apresenta clima quente, com temperaturas elevadas durante praticamente todo o ano. A acelerada expansão urbana pela qual a cidade vem passando nas últimas décadas tem resultado na diminuição das áreas verdes e no aumento expressivo de áreas impermeáveis, pavimentadas e edificadas, contribuindo para o aumento da temperatura do ar no micro clima urbano. Este fator é mais um agravante no desconforto térmico causado pelo excesso de calor no interior das edificações na cidade.

Em virtude do seu clima quente, a questão do conforto térmico assume importância significativa nas edificações, uma vez que estas devem proteger os ocupantes das condições rigorosas de temperatura do clima local. Assim, a preocupação com o conforto térmico deve ter relevância significativa na elaboração de projetos de edificações na cidade. Porém, percebe-se que em geral as edificações não respondem às necessidades de conforto térmico, fato resultante da desconexão dos projetos com a realidade climática da cidade.

Em vista disto, este trabalho insere-se na atual discussão sobre pesquisa científica e prática de projeto no que diz respeito ao conforto térmico em edificações. Tem seu foco na tentativa de se estabelecer uma aproximação entre os projetistas e o conhecimento produzido no ambiente de pesquisa, no sentido de incorporar aos projetos conceitos favoráveis ao conforto térmico para as edificações da cidade. Para tanto, a partir da utilização de ferramentas já existentes e de uma análise detalhada dos componentes do clima local, cria um conjunto de recomendações de projeto específicas para a cidade Ribeirão Preto. Tais recomendações são de fácil compreensão e utilização pelos projetistas, e visam a aplicação de estratégias favoráveis ao conforto térmico de maneira simplificada e objetiva. Este conjunto de recomendações resulta num manual prático ilustrado que pode configurar-se como uma importante ferramenta de projeto para os profissionais de projeto da cidade. 
Mesmo apresentando clima quente, com temperaturas elevadas durante quase todo o ano, Ribeirão Preto carece de estudos e pesquisas sobre o clima local e o conforto térmico do ambiente construído. Além disto, uma série de fatores e limitações estabelece um distanciamento entre a prática do projeto arquitetônico e os conceitos de condicionamento térmico passivo em edificações. É neste contexto que este trabalho se justifica, pois propõe uma maneira de minimizar este distanciamento através de uma ferramenta voltada para a prática profissional, mas baseada em informações científicas.

\subsection{OBJETIVOS}

Este trabalho tem como objetivo principal gerar um conjunto de recomendações de projeto para edificações na cidade de Ribeirão Preto, sob a ótica do conforto térmico no ambiente construído.

Tais recomendações devem ser gerais, de fácil aplicação e voltadas para as primeiras fases do processo de projeto, sendo específicas para a cidade de Ribeirão Preto. Visando buscar uma aproximação dos profissionais com as informações do ambiente de pesquisa, pretende-se que o conjunto de recomendações dê subsídios à criação de um manual prático de projeto. Este manual deve ter uma linguagem clara e ilustrada e após sua conclusão será disponibilizado por meios eletrônicos e/ou impressos, buscando sua efetiva utilização por parte dos profissionais da cidade. 


\section{CLIMA: CONCEITOS E CLASSIFICAÇÕES}

Definimos clima como o ambiente atmosférico constituído pela série dos estados atmosféricos que ocorre num lugar em sua sucessão habitual. A noção de clima se refere primeiramente a um lugar, a uma estação. Critério comum justificado pela observação científica. O conjunto das variações atmosféricas que registram nossos sentidos difere de um lugar a outro com grande rapidez: em cada lugar mostra uma individualidade original, às vezes irredutível à individualidade mais próxima (SORRE, 1955).

Desde os primórdios o clima de uma localidade exerce influencia direta sobre as atividades humanas ali estabelecidas. Segundo Critchfield (1960), "a saúde humana, a energia e o conforto são mais afetados pelo clima do que por qualquer outro elemento do meio ambiente". As condições de temperatura, de dispersão (ventos e poluição) e de umidade do ar exercem destacada influência sobre a manifestação de muitas doenças, epidemias e endemias humanas.

Assim, para estudar o conforto térmico humano é imprescindível que previamente se faça um estudo climático. Devem ser avaliadas as particularidades do clima local, sua dinâmica e seus elementos climáticos, para então, constatar quais os fatores que exercem influências negativas e positivas no conforto térmico humano.

Costuma-se descrever o clima de um lugar citando as médias aritméticas de temperatura, pluviosidade, etc., que são registradas em um determinado lugar. Porém, usar modelos matemáticos pode ser insuficiente para se estudar um fenômeno variável como o clima. Sabe-se que duas áreas podem ter as mesmas médias numéricas para os elementos climáticos e apresentarem características climáticas diferentes. Portanto é importante compreender como se dá a dinâmica 
atmosférica dessa área: as variações diárias anuais da temperatura, da umidade, da pressão atmosférica e o porquê dessas oscilações.

Ainda de acordo com Sorre (1955), o clima é a sucessão habitual dos tipos de tempo num determinado local da superfície terrestre, e o tempo é conjunto de valores que num dado momento e num certo lugar, caracterizam o estado atmosférico. Os elementos mais importantes para a explicação da mudança no comportamento do estado atmosférico são as massas de ar. Estas constituem volumes da atmosfera que têm algumas propriedades em comum em virtude da área em que se localizam. Existem massas de ar polares, equatoriais, tropicais, oceânicas, continentais, entre outras, que se movem continuamente. O encontro de duas massas de ar com diferentes temperaturas recebe o nome de "frente".

O ar atmosférico está sempre em movimento, na forma de massa de ar ou de vento. Dependendo da estação do ano, as massas avançam para o território brasileiro ou dele recuam. Se uma massa de ar possui características particulares de temperatura e umidade, torna-se responsável pelo tempo de uma área. Seus avanços ou recuos é que vão determinar o clima, pois a dinâmica das massas de ar influencia diretamente nos elementos do clima, como temperatura, umidade, pluviosidade, regime de ventos e pressão.

Numa mesma região, onde atuam determinadas massas de ar, podemos ter duas localidades próximas, nas quais os elementos do clima têm comportamentos distintos. Isto ocorre devido às características fisiográficas de cada local, como latitude, altitude, relevo e proximidades a grandes massas de água. Estas características atuam como fatores de modificação das condições iniciais do clima, e têm influência sobre os dados de temperatura, umidade, pressão, precipitação e regime de ventos.

Não há sequer duas regiões que apresentem características climáticas iguais, mas por questão de simplificação, surgiram algumas classificações, que agrupam regiões com características climáticas semelhantes. No Brasil, as classificações climáticas mais adotadas são a de Arthur Strahler e a de Wilhem Köppen. Apesar de 
generalizadas, tais classificações são importantes para um primeiro contato com as características climáticas de determinado local.

A classificação de Strahler (ANEXO A) baseia-se nas áreas da superfície terrestre, controladas ou dominadas pelas massas de ar. De acordo com ela, predominam no Brasil cinco grandes climas: tropical, tropical semi-árido, litorâneo úmido, equatorial úmido e subtropical úmido. De acordo a figura 2.3, Ribeirão Preto possui clima tropical, quente e semi-úmido, com verão chuvoso e inverno seco (área em amarelo).

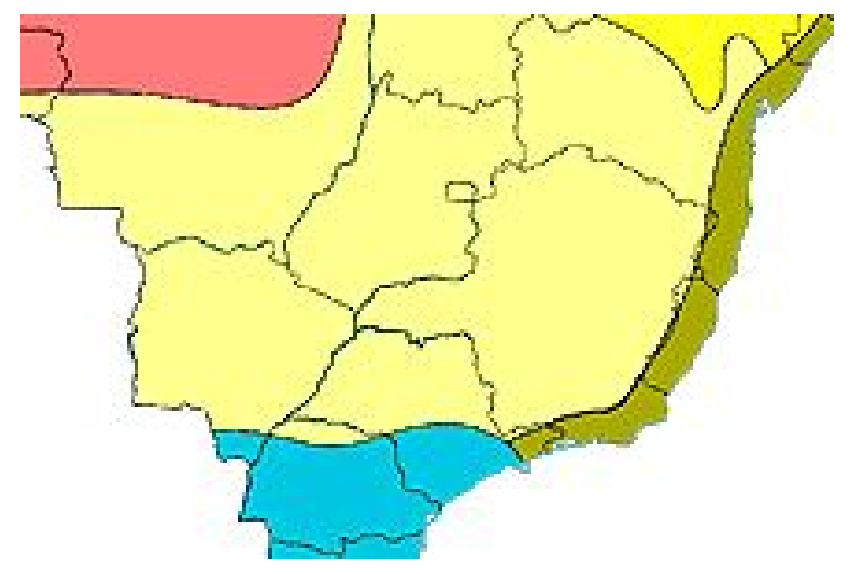

Figura 2. 1 Detalhe do Mapa Climático de Strahler para o Brasil com a localização da cidade de Ribeirão Preto (ANEXO A).

A classificação de Köppen (ANEXO A) baseia-se fundamentalmente nos valores de temperatura, precipitação e na distribuição destes entre as estações do ano, não levando em consideração a dinâmica das massas de ar. Observando a figura 2.4, a cidade de Ribeirão Preto encontra-se na área de clima tipo Cfa (em amarelo), ou seja, mesotérmico úmido com verões quentes. Porém de acordo com a tabela desta classificação (ANEXO A) seria mais correto apontar o clima tipo Cwa (em verde escuro), ou seja, mesotérmico sub-úmido com inverno seco e verão quente. 


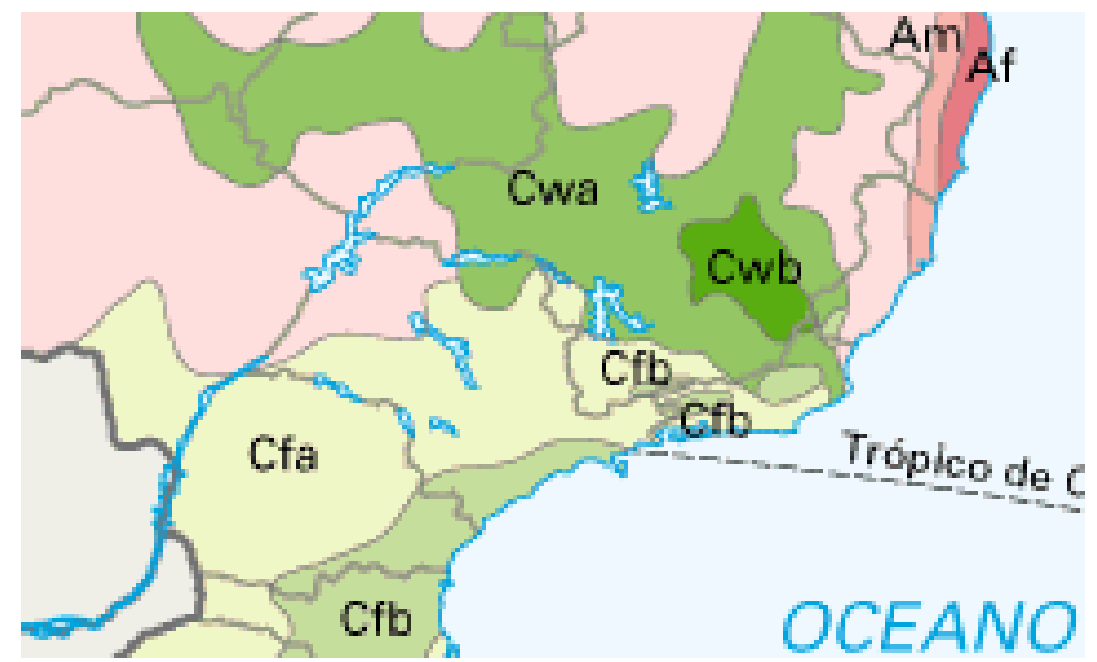

Figura 2. 2 Detalhe do Mapa Climático de Köppen para o Brasil com a localização da cidade de Ribeirão Preto (ANEXO A).

Temos ainda uma classificação do Instituto Brasileiro de Geografia e Estatística (IBGE), para o território brasileiro (ANEXO A). De acordo com o mapa abaixo, Ribeirão possui clima sub-quente úmido (área verde).

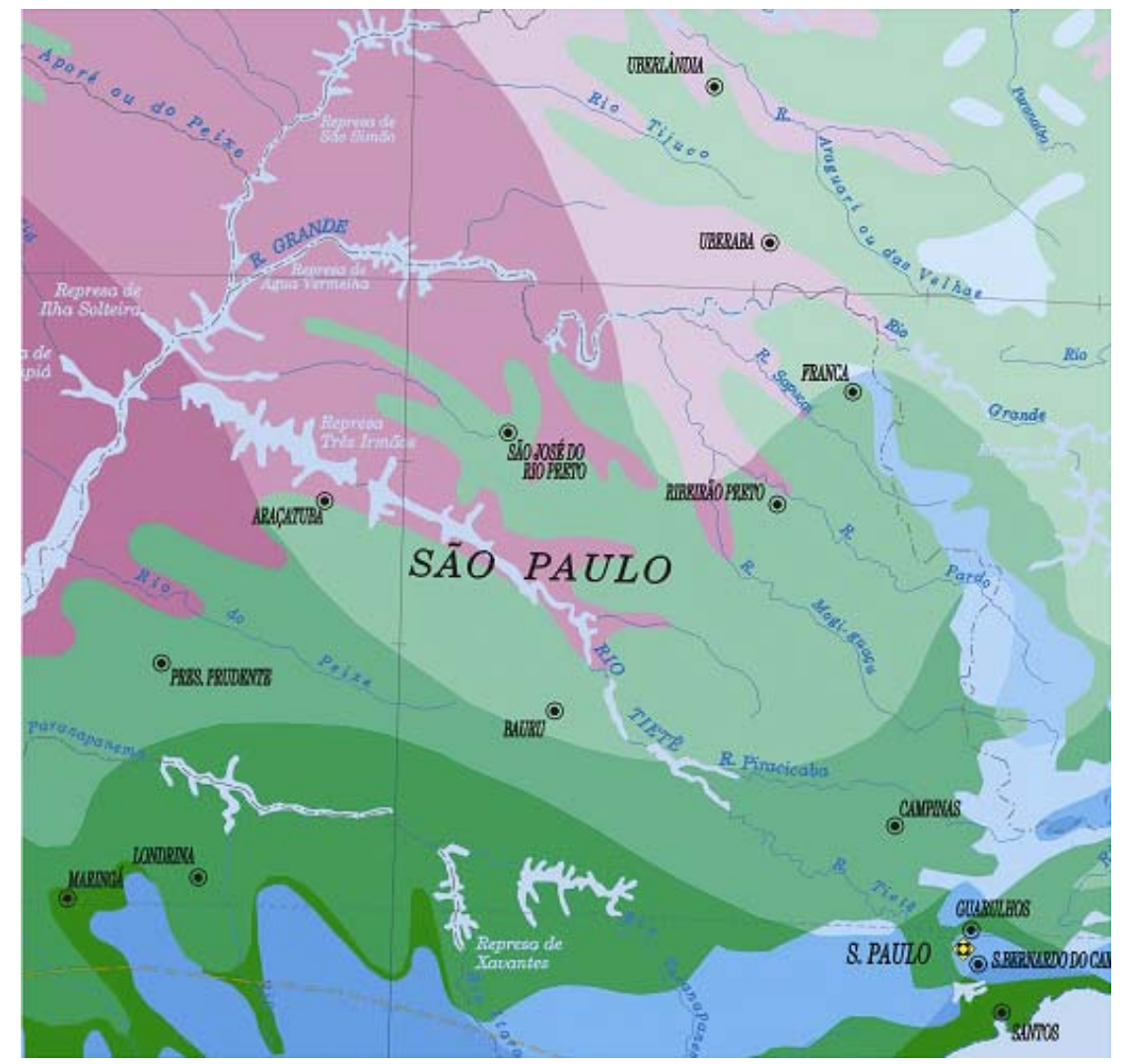

Figura 2. 3 Detalhe do mapa climático do IBGE com a localização da cidade de Ribeirão Preto (ANEXO A). 
Porém, se levarmos em consideração os dados de temperatura e pluviosidade na tabela desta classificação (ANEXO A), seu clima seria definido como quente semiúmido (área rosa claro).

Nos mapas das três classificações apresentadas pode-se ver que a localização do município de Ribeirão Preto situa-se em áreas de transição entre dois ou mais tipos climáticos, o que resultou em divergências tanto dentro de uma mesma classificação quanto entre as três apresentadas. De maneira geral as três classificações apontam três características em comum para o clima da cidade: clima quente, semi-úmido, inverno seco e varão chuvoso. Para melhor caracterizar o clima local, o capítulo 5 deste trabalho apresenta uma análise mais aprofundada, com base nos dados de seus elementos climáticos e na observação de suas características e particularidades. 



\section{INFLUÊNCIA DO CLIMA EM EDIFICAÇÕES}

Desde as primeiras civilizações as edificações tinham o papel principal de proteger das intempéries, configurando como uma segunda vestimenta do indivíduo. O clima sempre foi o principal fator determinante na elaboração das construções e devido à ausência de mecanismos de condicionamento artificial, técnicas e materiais naturais eram amplamente utilizados como atenuantes do clima nas habitações. Assim, para as diversas zonas climáticas do planeta, encontramos respostas arquitetônicas muito distintas. Muitas vezes estas respostas vão de encontro a uma arquitetura vernacular, onde materiais e técnicas construtivas peculiares do local são utilizados de modo a propiciar melhor conforto térmico nas edificações.

Ao longo do tempo os conceitos vernaculares de proteção climática foram se perdendo gradualmente. A revolução industrial contribuiu para a mecanização de métodos e materiais construtivos no desenvolvimento das cidades. Assim como em outros países, as identidades construtivas típicas de cada região do Brasil foram dando lugar aos conceitos da arquitetura moderna e importação do estilo internacional.

O aspecto formal monopoliza a atenção de uma grande quantidade de profissionais. Assistimos a um enorme intercambio de estilos soluções e expressões entre afastadas regiões do mundo sem que se realize um estudo a fundo das necessárias adaptações ao novo meio. Os críticos contribuem muitas vezes a esta desorientação quando julgam somente os valores estéticos dos edifícios (RIVERO, 1985).

Outro fator que contribuiu para o progressivo abandono das questões climáticas na arquitetura foi a disponibilização de equipamentos condicionadores térmicos. A possibilidade de utilização de tais equipamentos trouxe aos projetistas a falsa idéia de que preocupações como clima não eram mais relevantes, uma vez que poderiam 
climatizar o edifício artificialmente. Este conceito foi amplamente difundido pelo mundo, e em locais com clima quente, o aparelho condicionador de ar passou a ser a principal, ou muitas vezes a única solução para o condicionamento térmico dos ambientes.

Porém, a utilização de aparelhos condicionadores em larga escala e sem critérios logo se mostrou inadequada e prejudicial à fisiologia do homem. De acordo com Rivero (1985), a utilização de equipamentos de ar condicionado absorve o calor que ingressa no ambiente, resfriando a temperatura interna do ar. Mas mesmo com a sua utilização, as temperaturas superficiais dos elementos de vedação permanecem inalteradas e irradiando calor para os ocupantes. Estes portanto, continuam a receber calor por radiação das superfícies mais quentes ao mesmo tempo em que perdem calor por convecção para o ar mais frio, o que acelera sua atividade metabólica causando desgaste físico. Além disto, a utilização de equipamentos condicionadores de ar aumenta significativamente o consumo de energia das edificações, confrontando com o cenário atual de escassez de recursos energéticos.

O papel da ciência na arquitetura vem se tornando cada vez mais pálido, a construtividade e o desempenho apresentam-se muitas vezes irrelevantes em detrimento de questões que pouco tem a ver com o propósito da edificação. A arquitetura tem se tornado semelhante à indústria da moda, onde critérios puramente estéticos sobrepujam razões científicas (SZOKOLAY, 1994).

\subsection{ARQUITETURA BIOCLIMÁTICA}

Em 1960, os irmãos Olgyay, pioneiros na aplicação da bioclimatologia na arquitetura, criaram a expressão 'projeto bioclimático'. O objetivo era buscar satisfazer às exigências de conforto através de técnicas e materiais disponíveis, de acordo com as características climáticas locais. Este conceito ganhou maior força na década de 70 , quando ocorreram as primeiras crises energéticas. A partir daí constata-se maior 
preocupação com a conservação de energia e com os impactos ambientais provocados pela construção civil. (NEVES, 2006)

Uma buena arquitectura 'bioclimatica' es aquella que permite que el edifício se beneficie de ambientes interiores próximos al confort para um margen de variacion de lãs condiciones exteriores bastante amplio, sin el recurso al condicionamiento de aire artificial. Cuando los mecanismos se revelan necessários, la arquitectura bioclimática permite gastar uma cantidad reducida y hacer economias. (IZARD; GUYOT, 1983)

Para Olgyay (1998), o projeto bioclimático pode ser definido como o que utiliza as condições favoráveis do clima com o objetivo de satisfazer as exigências de conforto térmico do homem. A seguir, um esquema adaptado de Puppo e Puppo (1972), representa um organograma para o projeto bioclimático:

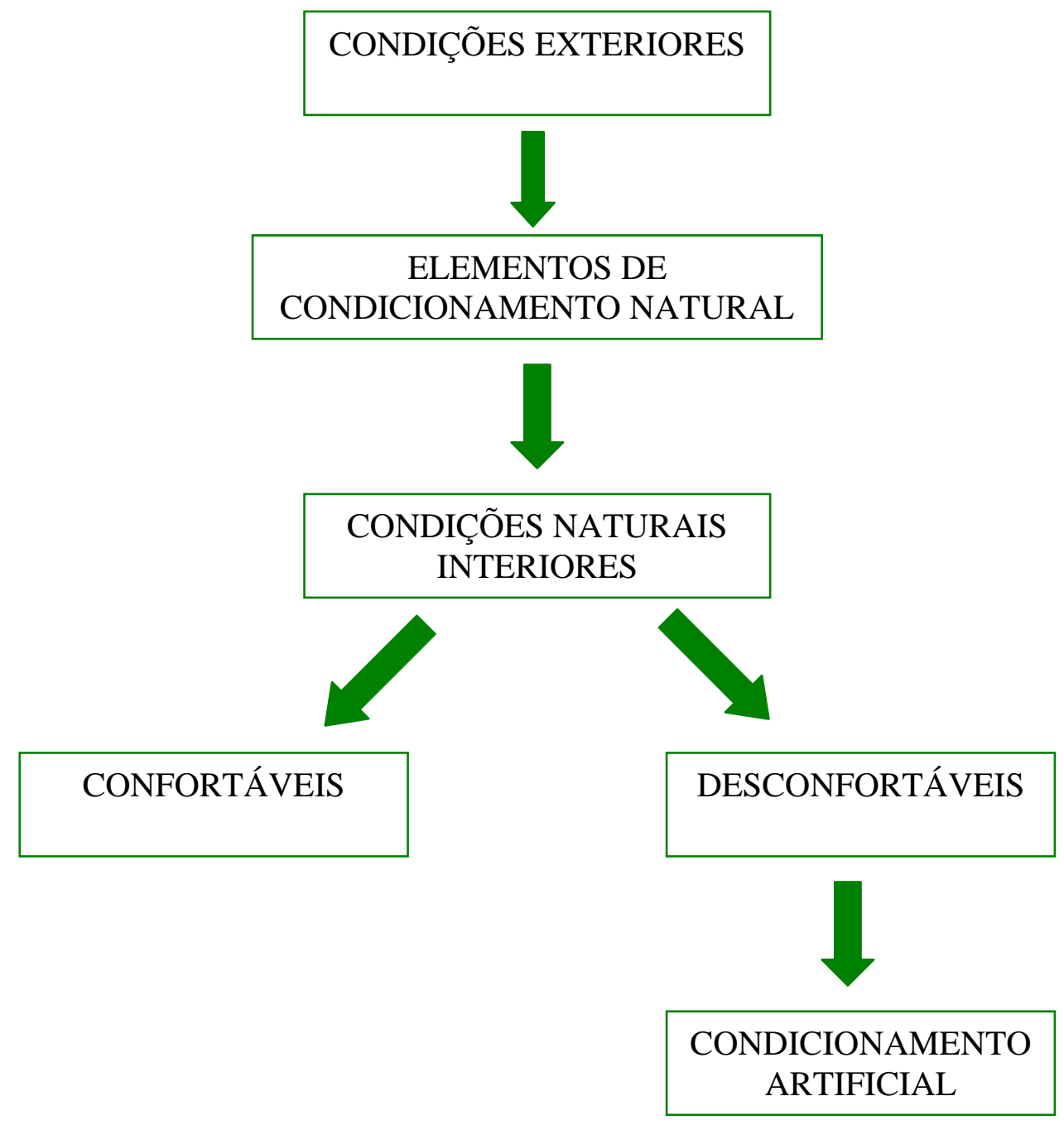


Os projetistas têm possibilidade de intervir sobre as variáveis do meio para melhorar qualidade térmica dos espaços. A forma e orientação dos volumes, a utilização de dispositivos de controle de radiação, a seleção adequada de materiais e procedimentos e a previsão de ventilação adequada, influenciam diretamente no ganho térmico que a edificação terá e conseqüentemente nas trocas de calor entre esta e o indivíduo que a ocupa (RIVERO, 1985). A correta utilização dos princípios bioclimáticos pode prover conforto aos ocupantes sem que, necessariamente, se faça uso de mecanismos artificiais. Em se tratando de clima quente, pode-se destacar duas principias estratégias de condicionamento natural que podem prover maior conforto às edificações: proteção à radiação solar e ventilação natural.

A ventilação natural é uma importante estratégia para a retirada de calor do interior dos ambientes. Aliada a certas condições de umidade, contribui para a sensação de conforto do indivíduo como indica o índice de temperatura efetiva corrigida (KOENIGSBERGER et al, 1973).

The simplest strategy for improving temperature, under still air conditions, seems to be warm is by daytime ventilation [...] this is particularly the case when the humidity is high and so higher air speed increases the rate of sweat evaporation from the skin, thus minimizing the discomfort from the wet skin. (GIVONI, 1994)

A sensação de diminuição da temperatura ocorre quando o movimento de ar facilita as trocas de calor entre o indivíduo e o meio, pela evapotranspiração. Porém o uso dos índices de temperatura efetiva para estabelecer situações de conforto é limitado, pois não considera a radiação dos elementos de vedação ao indivíduo e depende de condições de umidade favoráveis. No ambiente construído, o fluxo de ar pode configurar uma ventilação cruzada ou por efeito chaminé. A ventilação cruzada ocorre por ação dos ventos e da pressão que este exerce na edificação, através de aberturas de entrada e saída dispostas nas fachadas com pressão positiva e negativa respectivamente. Já o efeito chaminé ocorre pela diferença de temperatura que origina um fluxo ascendente, onde as aberturas possuem diferença considerável de altura, sendo a de entrada mais baixa e a de saída mais alta. 
Mas a eficiência da ventilação natural no conforto térmico dos ambientes possui algumas limitações em relação à sua aplicação em projetos. O dimensionamento e posicionamento entre as aberturas de entrada e saída assim como os volumes de trocas de ar, englobam cálculos complexos e conceitos de dinâmica dos fluidos. De regime variável, qualquer alteração na velocidade ou direção do vento afeta a incidência e o volume de trocas de ar no interior. Elementos externos interferem no comportamento dos ventos, podendo alterar as condições de ventilação externas e consequentemente, sua penetração nos ambientes internos. A ventilação nos ambientes internos também depende da operação e manuseio dos caixilhos pelos usuários.

A radiação solar é a principal responsável pelo desconforto térmico em edificações em locais de clima quente. As proteções solares são muito favoráveis uma vez que proteger a edificação da radiação contribui para minimizar o aquecimento das vedações e dos ambientes internos, melhorando suas condições térmicas. Além disto, a eficiência desta estratégia não está sujeita as alterações de tempo e elementos externos à edificação. Conhecendo a trajetória solar local, o projeto de proteções solares baseia-se em cálculos geométricos relativamente simples.

\subsection{CONFORTO TÉRMICO E AMBIENTE CONSTRUÍDO}

"O conforto térmico é um estado mental que reflete a satisfação com o ambiente térmico que envolve as pessoas." (ASHRAE, 1999).

A sensação humana de conforto térmico é bastante subjetiva e depende do efeito conjugado de inúmeros fatores. Dentre eles os principais estão em fatores ambientais, como temperatura de bulbo seco (TBS), temperatura média radiante (TRM), umidade relativa do ar (UR) e velocidade do ar, e fatores do individuo, como a taxa metabólica ou atividade, o grau de isolamento da vestimenta e a aclimatação (RORIZ, 2001). 
O homem realiza trocas de calor com o meio, através da condução, convecção, radiação e evapotranspiração pelo suor (RIVERO, 1985). A quantidade de calor intercambiada por cada um dos tipos de troca de calor irá depender de algumas variáveis. A vestimenta funciona como uma resistência térmica entre o indivíduo e o ambiente. O tipo e intensidade de atividade realizada alteram a quantidade de calor gerada pelo corpo. A temperatura superficial dos elementos que compõem a envolvente determinará o sentido do fluxo de calor entre o corpo e estas superfícies. A presença de radiação solar direta, temperatura, umidade e velocidade do ar influenciarão nas perdas de calor por convecção e evaporação. Alem disso, há outras variáveis que determinarão o grau de conforto, que dependem de cada indivíduo: a idade, o sexo e o grau de aclimatação.

O conforto térmico é caracterizado pela sensação de bem-estar do homem, ocasionada por um ambiente em função da atuação conjunta das variáveis mencionadas. Assim, há uma faixa efetiva de ocorrência de tais elementos, para a qual o homem mantém-se em conforto térmico, ou seja, não está estressado nem por calor nem por frio. É a chamada "zona de conforto térmico". Nestas condições, ou seja, nesta faixa, o esforço termorregulatório do homem é mínimo e o desempenho em qualquer atividade é otimizado. Ao longo de muitos anos, diversos pesquisadores têm procurado alternativas no sentido de predizer o nível de conforto térmico, objetivando expressar num único valor: o efeito conjunto das variáveis do ambiente térmico sobre o homem. Assim, por meio dos índices do ambiente térmico, pode-se expressar a sensação térmica experimentada pelo homem, submetido a um determinado ambiente. (SEELIG; ZEPKA; FOSTER, 2002).

A aplicação destes índices permite que se estabeleçam zonas de conforto térmico delimitadas graficamente sobre nomogramas ou diagramas, que indicam condições ótimas e limites de conforto através de valores combinados das variáveis de temperatura e umidade.

A partir de estudos detalhados e quantitativos dos mecanismos de trocas de calor e das variáveis vários autores, entre eles Givoni (1992), propõem as chamadas cartas bioclimáticas. Estas são elaboradas a partir das zonas de conforto térmico e proporcionam de maneira integrada informações sobre comportamento climático do 
entorno e previsão de estratégias para a correção deste comportamento quando fora da zona de conforto. A carta bioclimática de Givoni relaciona valores de Temperatura de Bulbo Seco, Umidade Relativa e Umidade Absoluta, delimitando áreas para adoção de estratégias construtivas.

Segundo Roriz (1987), que compara nove métodos de zonas de conforto, há uma grande diversidade entre elas e alguns chegam a ser pouco adequados para aplicação em projetos. Bogo et al (1994), analisaram as aplicações de diversas cartas bioclimáticas, sobre seus aspectos conceituais e práticos, concluindo que a carta bioclimática de Givoni adaptada para países em desenvolvimento era a mais adequada para estudos no Brasil. Roriz, Ghisi e Lamberts (1999), propõem uma adaptação da carta bioclimática original de Givoni para um zoneamento climático para arquitetura no Brasil, que foi utilizado na elaboração da norma NBR 15220 da Associação Brasileira de Normas Técnicas (ABNT).

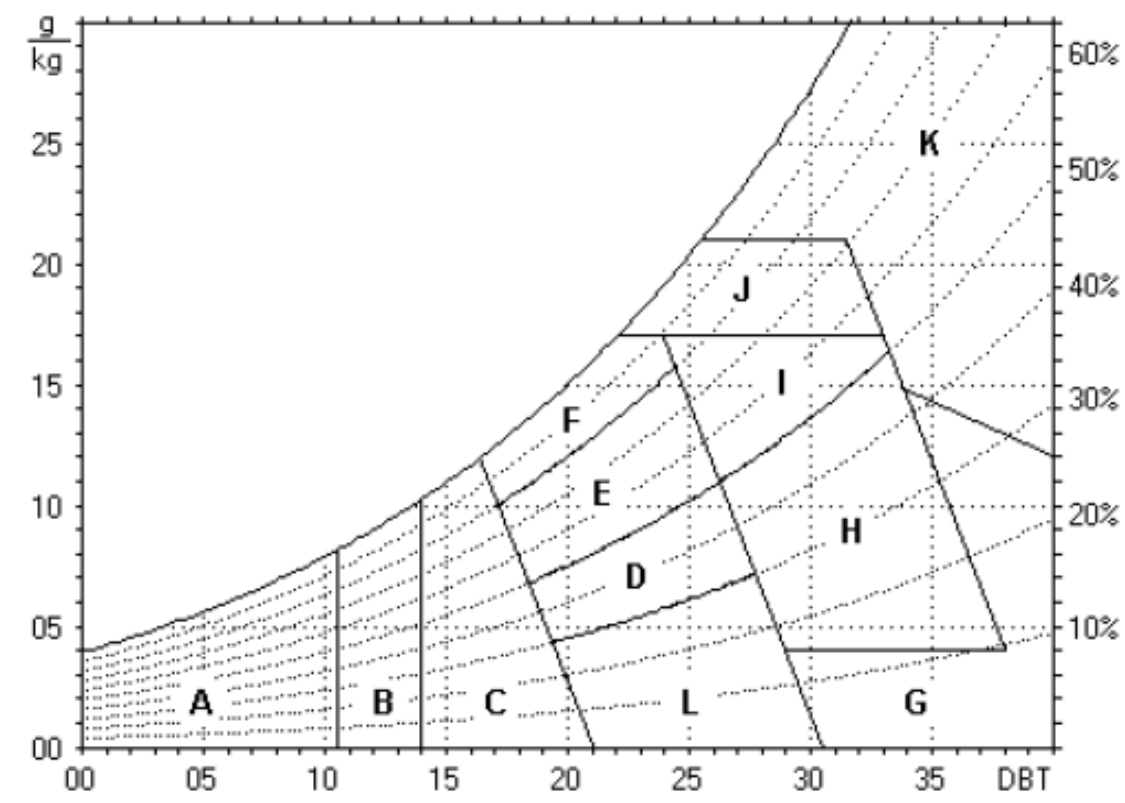

Figura 3. 1 Carta Bioclimática Adaptada ao Brasil - (RORIZ; GHISI; LAMBERTS,1999).

De acordo com a carta bioclimática adaptada de Givoni (figura 3.1) as estratégias de condicionamento passivo para edificações propostas são:
A - Sistema artificial de aquecimento
B - Aquecimento solar da edificação 
C - Massa térmica para aquecimento

D - Conforto térmico (baixa umidade)

E - Conforto térmico

F - Desumidificação (renovação do ar)

$\mathrm{G}+\mathrm{H}$ - Resfriamento evaporativo

$\mathrm{H}+\mathrm{I}$ - Massa térmica de refrigeração

I+J - Ventilação

$K$ - Sistema artificial de refrigeração

$\mathrm{L}$ - Umidificação do ar

A norma NBR 15220 - Desempenho Térmico de Edificações, foi elaborada com o objetivo de melhorar o desempenho térmico das edificações no Brasil através de melhor adequação climática. É dividida em cinco partes, sendo que a terceira parte apresenta recomendações e diretrizes construtivas quanto ao desempenho térmico de habitações unifamiliares de interesse social aplicáveis na fase de projeto.

Através de um zoneamento climático brasileiro e adaptação da carta bioclimática adaptada de Givoni, divide o país em oito zonas climáticas com características relativamente homogêneas, levando em conta a posição geográfica, médias mensais das temperaturas máximas, médias mensais das temperaturas mínimas e médias mensais das umidades relativas. A abrangência nacional do zoneamento climático pode levar a recomendações generalizadas, que atendam a uma determinada cidade e não a outra, ainda que pertençam à mesma zona. Mesmo assim, as recomendações da NBR 15220 são de grande importância para o país e representam um significativo passo na incorporação das questões de conforto térmico nos projetos de edificações.

Outra ferramenta bastante conhecida e considerada adequada para utilização no Brasil é o Método de Mahoney (ANEXO B), que a partir de sua classificação climática, tece recomendações de projeto para edificações visando o conforto térmico. Desenvolvido por Carl Mahoney em 1969 e posteriormente inserido em "Manual of Tropical Housing" (KOENIGSBERGER, 1974), vem sendo utilizado há mais de três décadas em muitos países e contextos climáticos. De acordo com RORIZ (2001), a simplicidade, principal virtude deste método, é ao mesmo tempo fator de algumas limitações: 
- adota apenas três intervalos de temperatura externa com diferença de $5^{\circ} \mathrm{C}$, o que para a diversidade climática brasileira pode ser excessivamente amplo.

- trabalha com médias de temperaturas, que podem não refletir a realidade climática local.

- $\quad$ a velocidade do ar não é considerada nos limites definidos por Mahoney.

Apesar de algumas limitações, o método possui vantagens didáticas ideais para uma ferramenta de projeto (EVANS, 1999):

- clareza na conjunção dos dados, análise do conforto e indicação de estratégias bioclimáticas

- facilidade e agilidade no preenchimento das tabelas

- os dados de entrada são simplificados e estão geralmente disponíveis em muitos centros urbanos pelas estações climatológicas

- produz recomendações referentes a componentes e métodos construtivos

Sabe-se que tanto a NBR 15220 quanto o método de Mahoney são ferramentas abrangentes e, portanto, podem gerar recomendações muito generalizadas. Segundo Konia (1981), a maioria das recomendações de projeto para climas tropicais tem seu foco nos cimas quente e úmido e/ou quente e seco. Por isso devese analisar o rigor e a representatividade de cada estação do ano, assim como as particularidades climáticas locais, para se estabelecer critérios de prioridade e adotar decisões corretas, que solucionem as questões de maior relevância para o local em questão (KONYA, 1981).

\subsection{CONDICIONAMENTO TÉRMICO NATURAL E CONSUMO ENERGÉTICO EM EDIFICAÇÕES}

Nas últimas décadas, a escassez de recursos energéticos trouxe à tona a questão da racionalização de energia. Muitos estudos têm mostrado a eficiência da aplicação das estratégias de condicionamento térmico passivo na redução do consumo energético nas edificações. Assim, além dos benefícios ao conforto humano, a 
utilização destas estratégias no projeto de edificações torna-se relevante diante do atual cenário energético mundial.

Desde 1985, com a criação do Programa Nacional de Conservação de Energia Elétrica (PROCEL), o Brasil vem tomando várias medidas em prol da eficiência energética em geral. Em 2001 ocorre a implementação da Lei de Eficiência Energética (no 10.295, de 17 de outubro de 2001), que dispõe sobre a Política Nacional de Conservação e Uso Racional de Energia. Mas somente em 2003, um programa específico para edificações foi lançado: o PROCEL Edifica, através do Plano de Ação para Eficiência Energética em Edificações. Este plano estabelece seis vertentes: arquitetura bioclimática, indicadores referenciais para edificações, certificação de materiais e equipamentos, regulamentação e legislação, remoção de barreiras à conservação de energia e educação. De acordo com o Ministério das Minas e Energia (MME), entre todas as ações que envolvem os planos de eficiência energética, a adequação arquitetônica seria uma das de menor investimento, podendo gerar economias de energia na ordem de $20 \%$ ao país (MME, 2007).

A partir daí o Grupo Técnico para Eficientização de Energia nas Edificações do País (GT-MME), começa a trabalhar no desenvolvimento da Regulamentação para Etiquetagem Voluntária do Nível de Eficiência Energética de Edifícios Comerciais, de Serviços e Públicos. Aplica-se, numa primeira instância, à edifícios comerciais e públicos com área útil mínima de $500 \mathrm{~m}^{2}$ ou tensão de abastecimento igual ou superior a 2,3kV. Incluem-se edificações condicionadas artificialmente ou naturalmente ventiladas. Em setembro de 2006 foi aprovada uma versão experimental do texto desta regulamentação (LAMBERTS et al, 2007).

Atualmente o MME, vem também promovendo o aprimoramento desta regulamentação através de consulta pública, que permite a participação e contribuição de interessados, como entidades representativas, pesquisadores, entidades governamentais e a sociedade em geral (MME, 2007).

De acordo com o MME, o Brasil não é um dos maiores consumidores de energia no mundo, mas seu consumo de energia elétrica vem aumentando significativamente nos últimos anos (figuras 3.2, 3.3 e 3.4). Mesmo com as medidas de conservação, 
em alguns anos o consumo de energia elétrica no Brasil tem chegado a $95 \%$ da sua capacidade. Segundo o último Balanço Energético Nacional (BEN), os setores residencial, comercial e público foram responsáveis por 22\%, 14,2\% e 8,5\% respectivamente, do consumo de energia elétrica total do país em 2006 (MME, 2007).
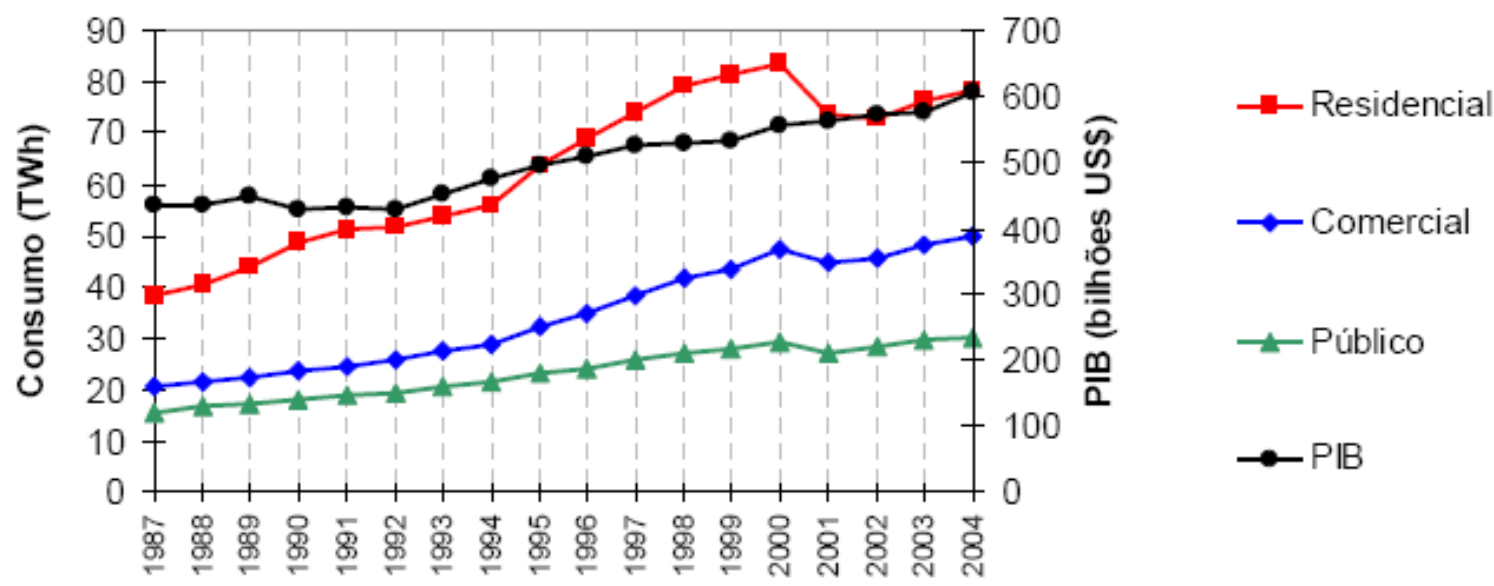

Ano

Figura 3. 2 Consumo de energia por setor relativo ao PIB no Brasil (LAMBERTS et al, 2007).

No Brasil, considerando os setores comercial e público, o sistema de ar condicionado é responsável por cerca de $20 \%$ do consumo total de energia das edificações (GELLER, 1990). No setor residencial, uma pesquisa denominada Pesquisa de Posses e Hábitos de Uso de Aparelhos Elétricos - SINPHA, vem sendo atualizada, e indica que o uso final de ar condicionado representa $20 \%$ do total de energia consumida. Em sua primeira versão, no ano de 1998, esta porcentagem era de apenas 8\% (LAMBERTS et al, 2007).

Ambos os estudos apresentam médias nacionais, que podem não representar a realidade de determinados locais. Em cidades com temperaturas mais amenas podem ter um consumo abaixo da média, enquanto que cidades com temperaturas mais elevadas podem ter um consumo acima da média nacional na utilização de aparelhos condicionadores de ar. Um exemplo disto é o caso de Salvador, onde dados mostraram que o consumo poderia chegar a $70 \%$ para o condicionamento de ar em edifícios de escritórios (MASCARENHAS; NERY; D’ALCANTARA, 1988). Não 
foram encontrados estudos sobre consumo de condicionadores de ar para o município de Ribeirão Preto. Como na cidade são registradas altas temperaturas durante a maioria dos meses do ano a autora acredita que, assim como no caso de Salvador, o consumo relativo ao condicionamento de ar em suas edificações possa ser maior que a média nacional de $20 \%$.

A problemática do consumo energético tem aumentado a preocupação com a questão do condicionamento térmico natural, contribuindo com a incorporação de conceitos bioclimáticos nas edificações. Porém, basear a aplicação destes conceitos apenas na questão do consumo energético é um apelo muito limitado. O condicionamento térmico natural deve ser advindo principalmente das questões humanas conforto e bem estar do indivíduo que ocupa a edificação, sendo a questão do consumo conseqüência disto.

\subsection{CONFORTO TÉRMICO EM EDIFICAÇÕES NO BRASIL}

No Brasil, a arquitetura atenta a princípios bioclimáticos, ganhou maior força na década de 60, com a migração de arquitetos pelo território nacional. Um dos expoentes desta produção é o arquiteto Severiano Porto, que atuou na Amazônia durante 36 anos. Projetando nesta região, com clima quente e úmido, previa proteções à radiação solar e às chuvas e a utilização da ventilação natural em suas obras como sistemas passivos de condicionamento térmico (NEVES, 2006). Um belo exemplar é o Centro de Proteção Ambiental de Balbina (figura 3.3). 


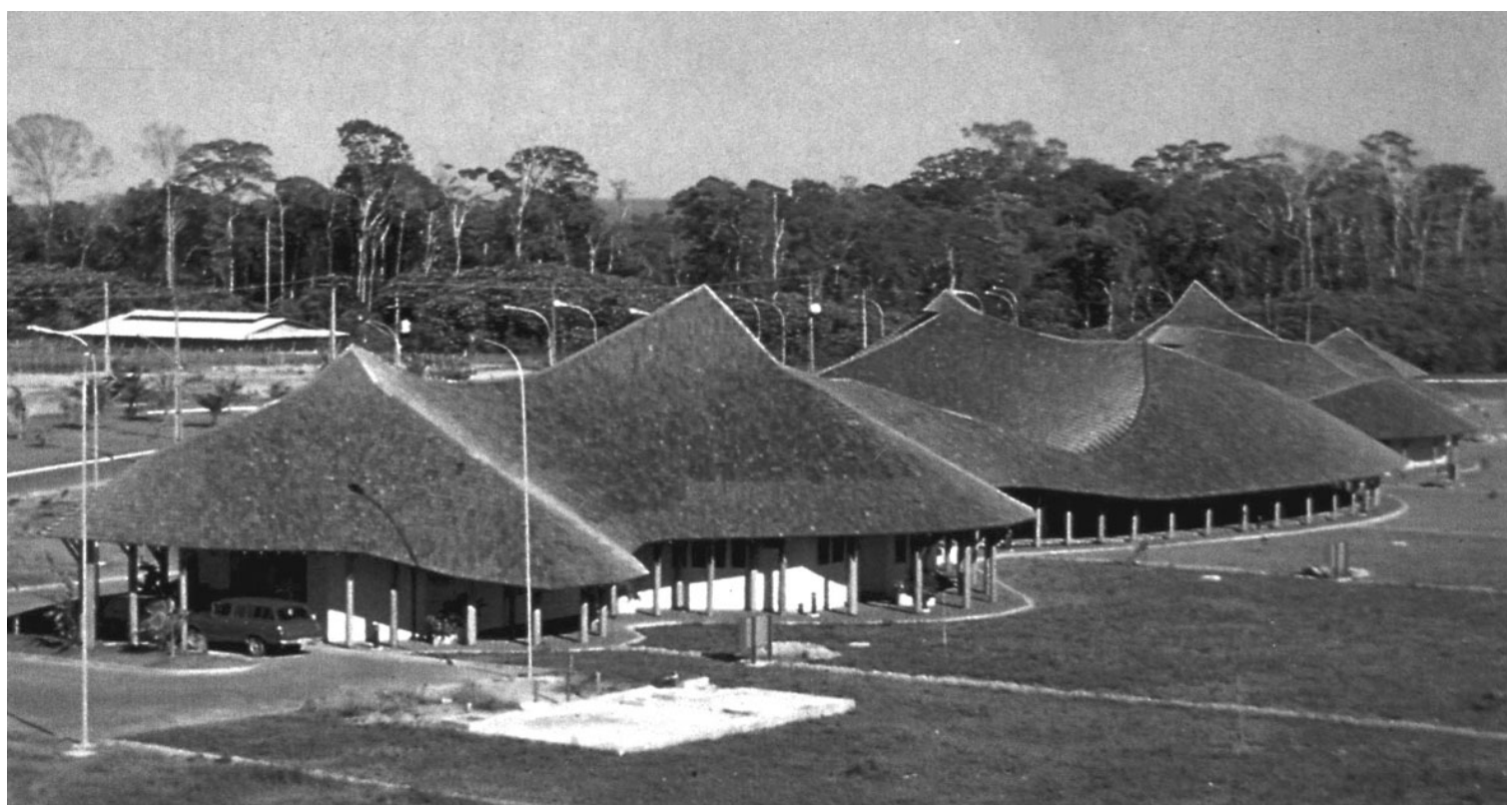

Figura 3. 3 Centro de Proteção Ambiental de Balbina (NEVES, 2006).

A cobertura, com longos beirais para proteção à radiação, é feita em estrutura de madeira e palha de buriti, material de baixa inércia térmica. A ventilação natural se dá pelo efeito chaminé, através do pé direito elevado da cobertura e de suas aberturas no topo, que permitem a ascensão e saída do ar quente, resultando em temperaturas mais amenas na zona de ocupação (NEVES, 2006).

Embora muitas vezes a bioclimatologia e o condicionamento térmico natural sejam associados a uma arquitetura com identidade vernacular, cabe ressaltar que estes conceitos não possuem compromisso com conceitos vernaculares. Atualmente o constante desenvolvimento de novos materiais e tecnologias construtivas vem contribuindo para a questão do conforto térmico, ampliando o horizonte de possibilidades na aplicação de materiais e técnicas de condicionamento térmico passivo nas edificações.

No sentido de uma breve análise qualitativa da questão do conforto térmico na arquitetura contemporânea brasileira, foram selecionados aleatoriamente alguns projetos em locais com clima quente e que apresentassem alguma abordagem em relação ao condicionamento térmico natural. 


\subsubsection{Hospital Rede Sarah de Fortaleza - CE}

O arquiteto João Filgueiras Lima, o Lelé, é internacionalmente conhecido, não só pela utilização de sistemas de concreto pré-moldado, como pelas preocupações climáticas e com o conforto ambiental, que fazem parte de sua filosofia e postura projetual. Lelé acredita numa forte relação entre o pré-fabricado de concreto e o desenvolvimento das galerias de ventilação e sheds utilizados em seus projetos (MONTERO, 2006). No projeto do hospital Sarah de Fortaleza (figura 3.4), o programa foi setorizado em "ambientes flexíveis" - que permitem a utilização de condicionamento natural - "e ambientes não flexíveis" - que exigem controle permanente das condições de temperatura e umidade, como o caso dos centros cirúrgicos. Os ambientes com condicionamento artificial estão localizados na parte posterior, permitindo melhor localização dos ambientes flexíveis, que se aproveitam da incidência dos ventos dominantes.

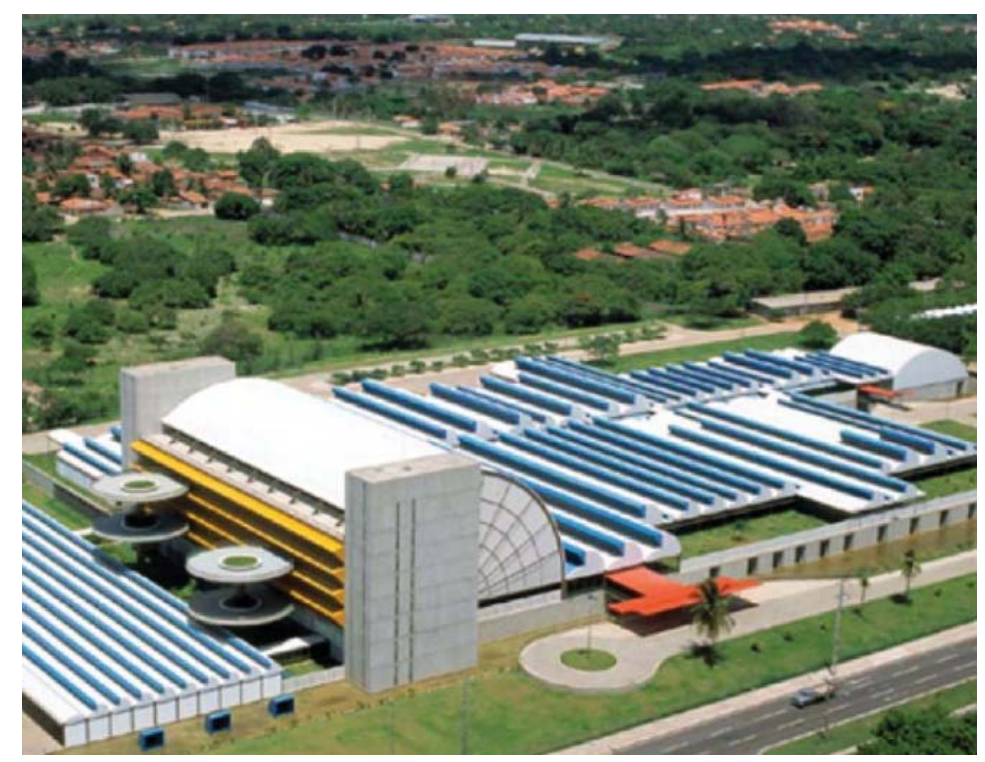

Figura 3. 4 vista aérea do Hospital Sarah Fortaleza (MONTERO, 2006).

Para atender aos princípios da ventilação natural, foram desenvolvidos dois sistemas, que podem operar simultaneamente: o de convecção e o de ventilação cruzada. No modo por convecção, o ar frio é injetado através das galerias de ventilação subterrâneas com nebulisadores de água externos, e extraído pelos 
sheds com as aberturas a favor dos ventos dominantes, dando o efeito de sucção (figura 3.5).

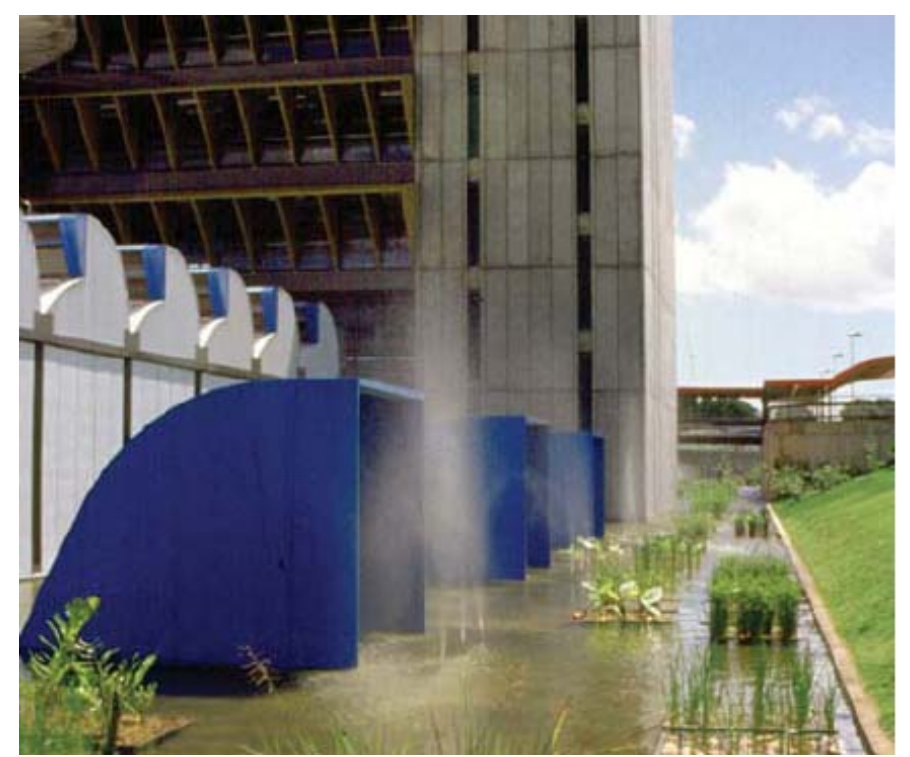

Figura 3. 5 entradas de ar das galerias de ventilação subterrâneas (MONTERO, 2006).

Uma grande cobertura em arco abrange a área do ginásio de atividades, varandas das enfermarias e jardim interno (figura 3.6). Esta foi projetada com brises móveis para que a proteção à radiação direta acompanhasse a trajetória solara e ainda permitisse a ventilação natural.

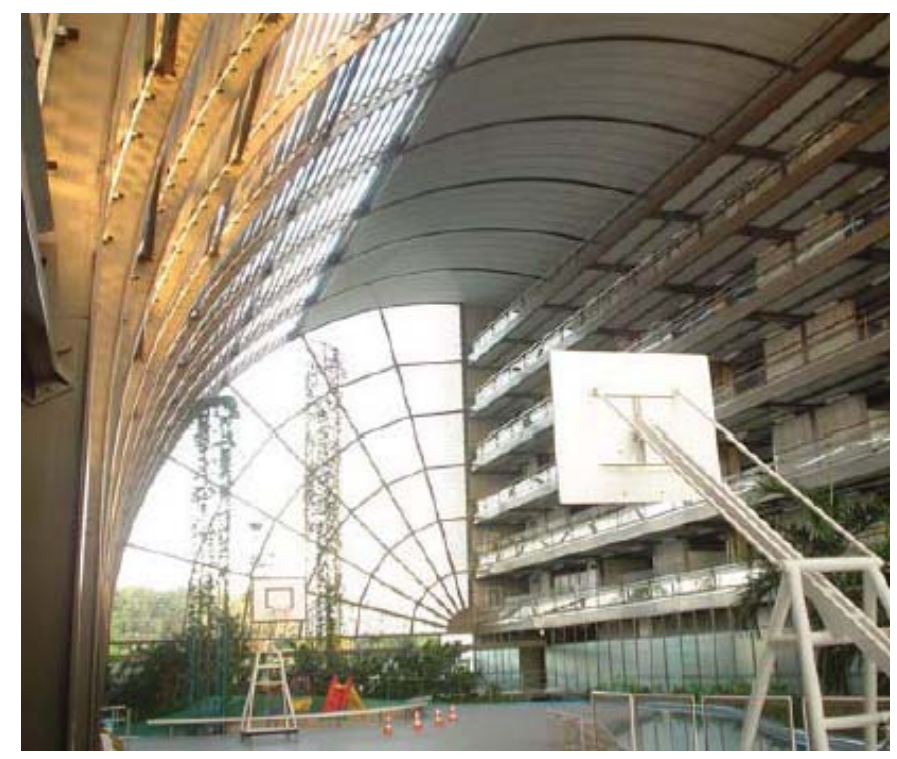

Figura 3. 6 vista interna do Hospital Sarah Fortaleza (MONTERO, 2006). 


\subsubsection{Residência de Itanhangá - RJ}

O arquiteto carioca Cláudio Bernardes ficou conhecido por seus mais de mil projetos executados ao longo de sua carreira e por sua intuitiva preferência por materiais naturais como madeira, palha, bambu, entre outros. Na casa de Itanhangá (figura 3.7), um dos últimos projetos antes de sua morte, "Cláudio desejava explorar novos caminhos e se afastar do rótulo de arquiteto da madeira" (Revista AU, 2004).

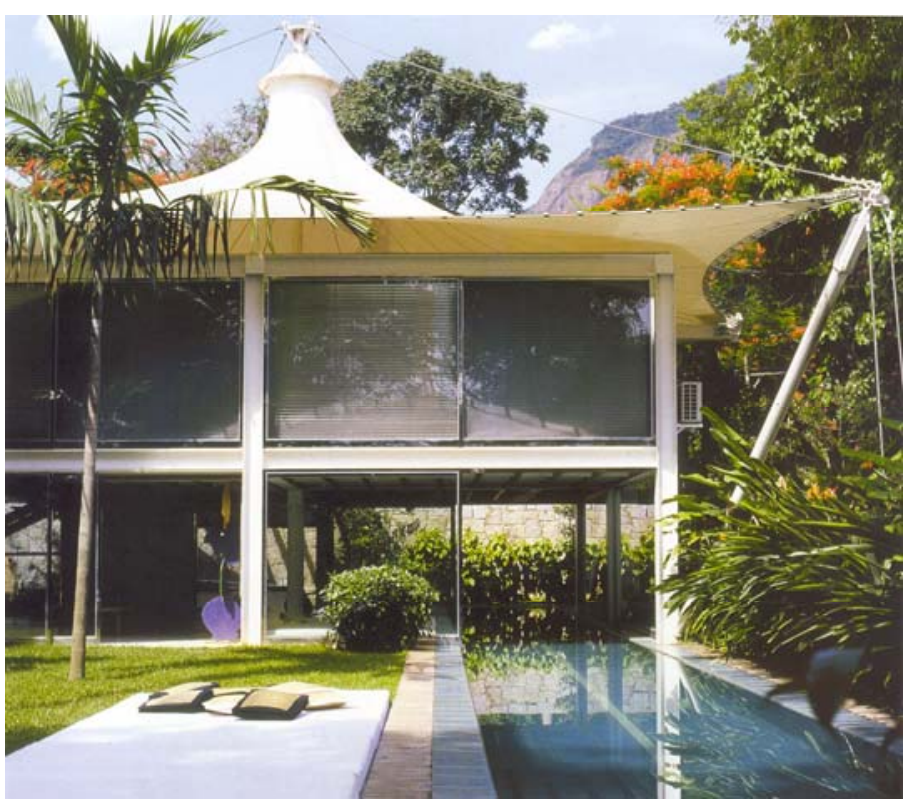

Figura 3. 7 Vista Residência Itanhangá (Revista AU, 2004).

A reportagem citada não faz menção à questão do conforto térmico, porém a autora identifica neste projeto uma interessante solução de cobertura e sombreamento favorável ao condicionamento térmico natural. Uma enorme tenda em lona tensionada cobre toda a edificação. Suspensa sobre o volume em estrutura metálica com fechamento em vidro e forro em madeira, protege-o da incidência da radiação solar direta pelo sombreamento e pela baixa absorção de calor devido à sua cor branca. Funciona também como cobertura de ático ventilado, pois o ar circula livremente sob a cobertura em lona, retirando o ar quente e minimizando a absorção de calor pelo forro (figura 3.8). 


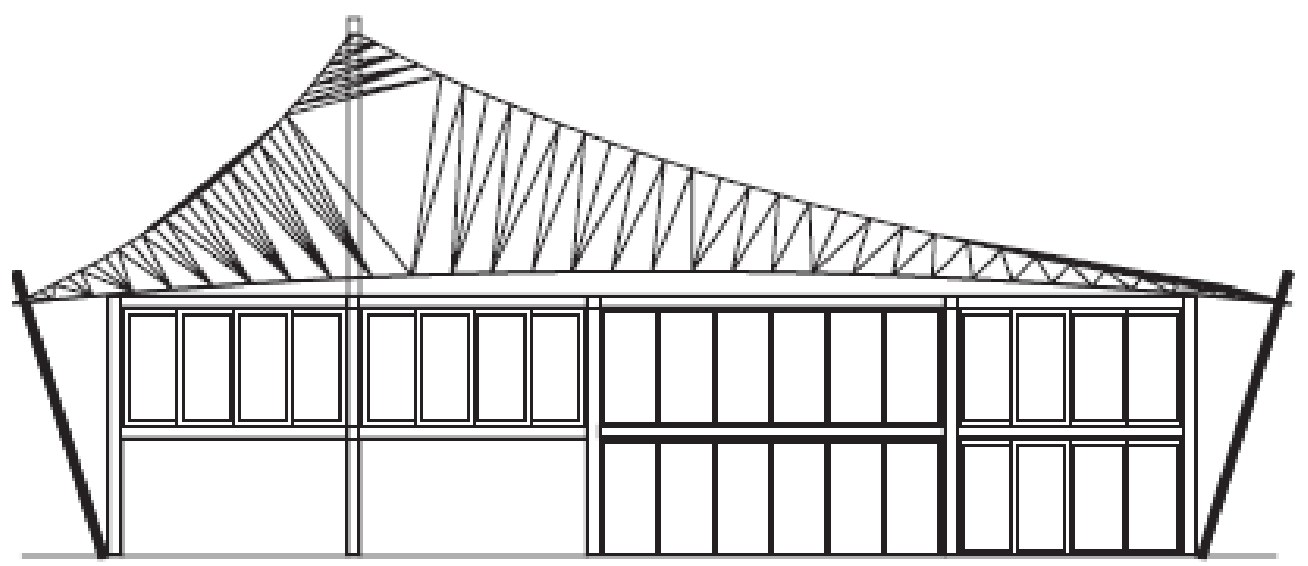

Figura 3. 8 Corte Residência Itanhangá (Revista AU, 2004).

\subsubsection{Sede da Petrobrás em Vitória - ES}

O projeto desenvolvido pelo arquiteto Sidônio Porto para a sede administrativa da Petrobrás em Vitória (figura 3.9), expressa a preocupação da empresa com a adoção de conceitos construtivos que resultem em eficiência energética. A empresa vem procurando aplicar em suas novas unidades uma orientação em defesa da prática de uma arquitetura bioclimática.

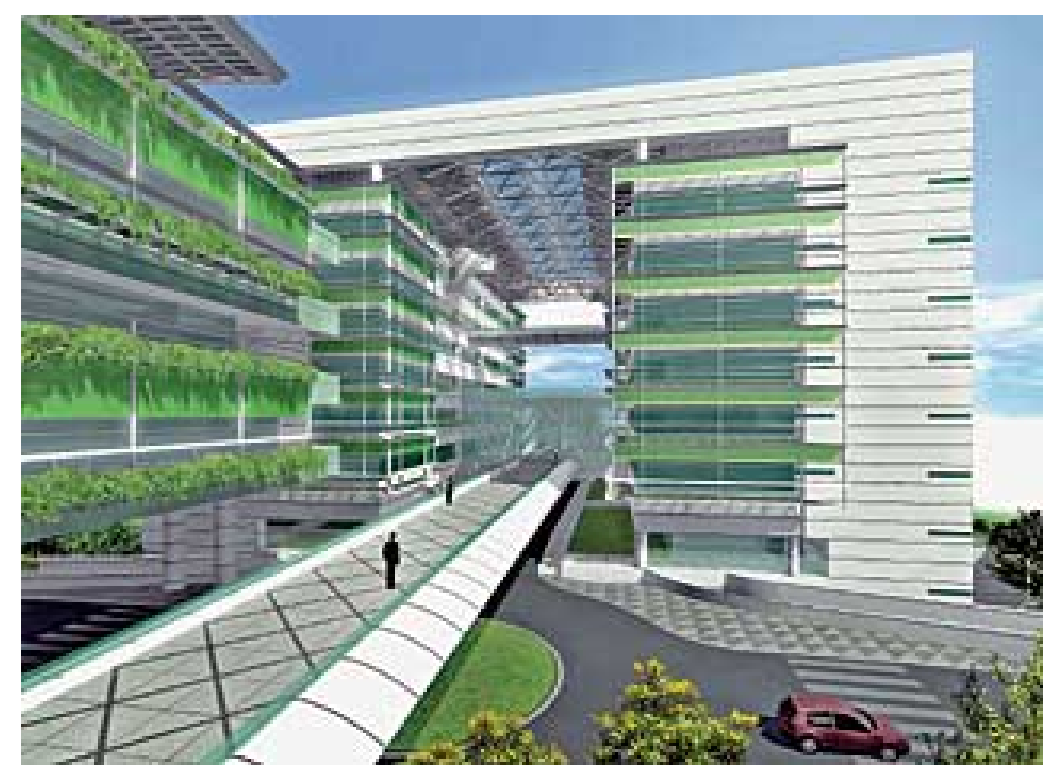

Figura 3. 9 Vista Sede da Petrobrás em Vitória (Revista FINESTRA, 2007). 
Para os estudos sobre conforto térmico foi contratada uma empresa de consultoria específica em conforto, o que permitiu que essa questão fosse avaliada ainda na fase de desenvolvimento do projeto.

Quanto ao entorno, procurou-se preservar as árvores mais antigas e de maior diâmetro, criando uma espécie de cinturão verde em torno dos edifícios, colaborando com o sombreamento. Os ambientes de maior permanência e com maior número de pessoas trabalhando foram dispostos ao longo das fachadas menos ensolaradas. As fachadas terão também brises fixos e móveis como proteção contra a radiação solar direta e melhor aproveitamento da luz natural (figura 3.10).

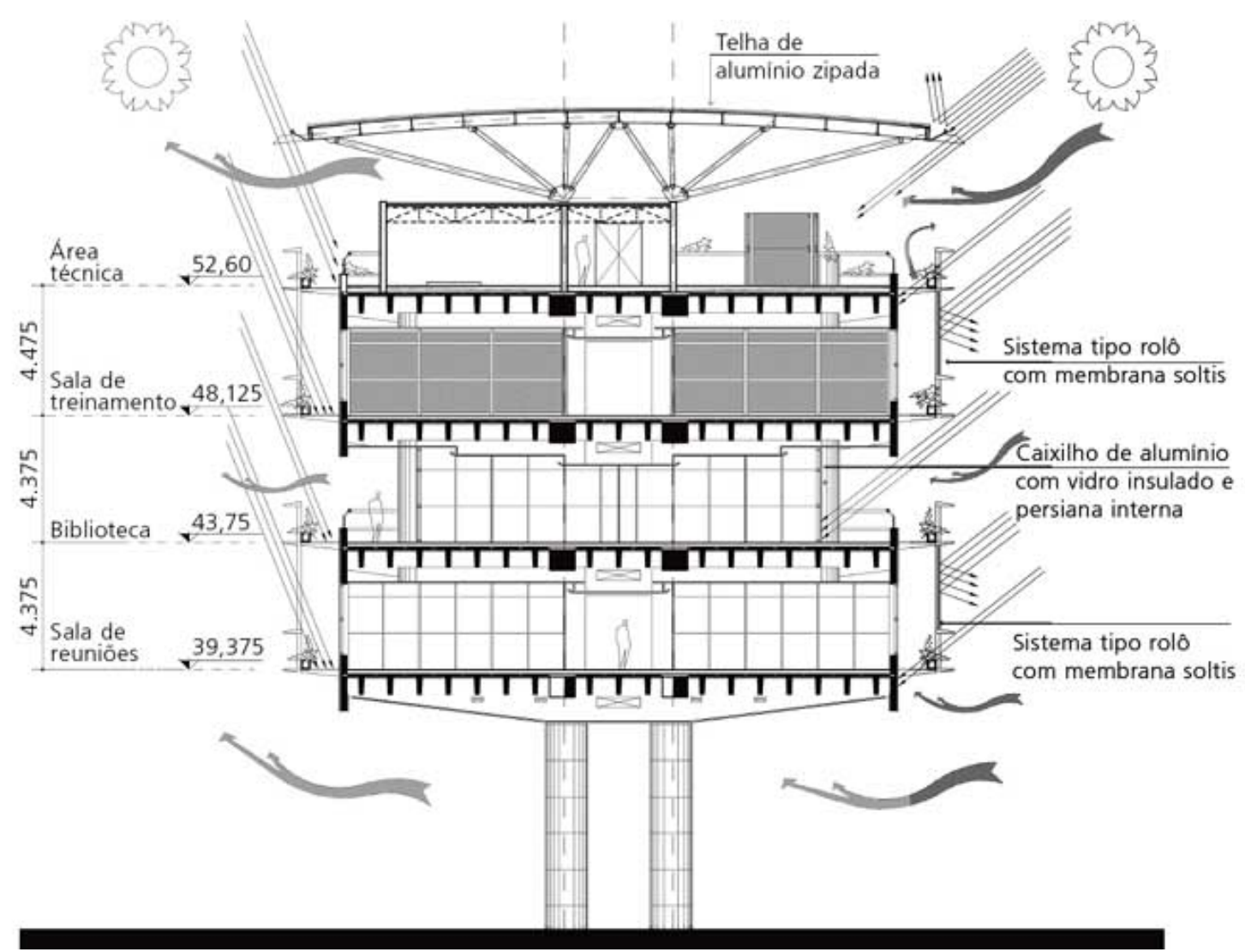

Figura 3. 2 Corte com sistema de proteção solar (Revista FINESTRA, 2007).

Além dos brises, um sistema com uma espécie de cortina de tela mecanizada irá reforçar o sombreamento em períodos mais críticos. Colocadas na parte externa do vidro, podem absorver e reter até $91 \%$ do calor contido na irradiação solar. Essa proteção corre dentro de trilhos, com acionamento manual ou motorizado, 
programado no computador, o que permite orientar os movimentos de abertura e fechamento conforme as condições de sombreamento e insolação de cada uma das fachadas. O espaço existente entre a tela e os vidros permitirá a circulação de ar (Revista FINESTRA, 2007).

\subsubsection{Considerações}

De acordo com os projetos analisados, pode-se constatar um aprimoramento das técnicas de condicionamento passivo ao longo dos últimos anos no Brasil. A constante evolução qualitativa e quantitativa das pesquisas em conforto térmico vem se refletindo, ainda que timidamente, na produção arquitetônica de inúmeros profissionais. Ainda assim não se pode dizer que esta produção seja significativa, pois ainda que os profissionais tenham a preocupação com o conforto térmico, esta muitas vezes acaba sofrendo limitações de projeto e por fim, cedendo espaço a outros conceitos dentro do processo. Esta questão terá maior abordagem através de algumas pesquisas apresentadas a seguir, no capítulo 4. 



\section{A PRÁTICA DO PROJETO ARQUITETÔNICO}

A estruturação conceitual do projeto e as decisões tomadas a fim de atender o programa de necessidades do projeto arquitetônico estão sob a responsabilidade dos profissionais envolvidos com a construção civil, principalmente do arquiteto.

Es tarea del architecto la utilización máxima de todos los medios naturales para producir uma vivienda lo más sana y agradable posible, al miesmo tiempo deberá buscar el ahorro em los costes, reduciendo al mínimo la necesidad de ayudas mecánicas para el control climático (OLGYAY, 1998).

O processo do projeto arquitetônico não é um processo linear e seu desenvolvimento se diferencia de um profissional ao outro. Porém, um fator comum aos profissionais é trabalhar com condicionantes básicos que são consideradas na definição do partido arquitetônico. A preocupação como o conforto térmico deve fazer parte destas condicionantes.

Durante a pesquisa, foram encontrados poucos trabalhos científicos que procuram avaliar a prática do projeto arquitetônico frente aos aspectos do conforto térmico.

Um estudo realizado por Cartana e Pereira (2007), baseou-se no envio de questionários a profissionais, estudantes de graduação e pós-graduação e professores em Florianópolis. As questões abordaram os métodos utilizados para a tomada de decisões nos projetos, a integração dos conceitos de bioclimatologia e as informações obtidas sobre os elementos climáticos. A porcentagem de resposta dos arquitetos autônomos foi de apenas 15\%. De acordo com as respostas obtidas, temos que a maioria dos profissionais entrevistados:

- desenvolvem os projetos levando em consideração os seguintes métodos: consulta à legislação, uso da intuição e experiência profissional, elaboração de croquis e perspectiva; 
- a visita ao terreno figura como a principal forma de levantamento dos elementos climáticos

- a produção arquitetônica está diretamente relacionada ao conjunto de leis de cada localidade, como o plano diretor e o código de obras.

- o custo da construção é fator limitante na adoção de estratégias bioclimáticas

Outro estudo semelhante realizado por Morishita e Schimid (2007), constata algumas falhas em relação à atuação dos profissionais de arquitetura no mercado da construção civil relacionadas ao conforto térmico. O estudo baseou-se no envio de questionários com questões pertinentes à ventilação natural, para mais de 2000 profissionais atuantes no estado do Paraná. O índice de respostas foi de apenas $14 \%$, que em primeira instância, demonstra uma falta de interesse por parte dos profissionais em contribuir com os estudos. Na análise e conclusão das respostas foi confirmada a hipótese de que os arquitetos fazem mau uso da ventilação natural, por falta de conhecimento do assunto. O estudo ainda conclui que:

- a maioria dos arquitetos considera importante a questão do conforto térmico, mas não possui conhecimento razoável sobre as reais necessidades de ventilação de um ambiente ou de clima especifico, nem sobre métodos de ventilação natural;

- muitos buscam auxilio junto a fornecedores de componentes, que tão pouco conhecem sobre ventilação nos ambientes;

Chvatal (1998), desenvolveu uma pesquisa objetivando saber o nível de interesse dos projetistas da cidade de Campinas pelo conforto térmico e pela forma com que eles lidam com este aspecto ao elaborarem projetos. A pesquisa relacionou vários tópicos, nos quais os resultados estão relacionados a seguir:

- Nível de importância do conforto térmico: para a maior parte dos entrevistados, o conforto térmico está entre os aspectos mais importantes a se considerar no desenvolvimento de um projeto.

- Análise do terreno: $74 \%$ dos entrevistados afirmam preocupar-se com a orientação do terreno em relação ao sol.

- Análise da insolação: apesar de 96\% dos entrevistados afirmarem que analisam a insolação, somente $6 \%$ utilizam algum método para esta análise. 
- Proteções solares: 68\% afirmam prever proteções solares, mas apenas 8\% utilizam algum método para especificar estas proteções.

- Análise da ventilação: apenas 40\% analisam a ventilação frequentemente; $50 \%$ já previram alguma vez o efeito chaminé, sendo que $20 \%$ utilizaram algum método e $30 \%$ não utilizaram nenhum método.

- Aspectos para escolha de materiais: a porcentagem de entrevistados que considera o conforto térmico em primeiro lugar para a escolha de materiais é: $88 \%$ para materiais de telhado; $76 \%$ para materiais de forro; $56 \%$ para materiais de paredes; $24 \%$ para materiais de pisos internos; $12 \%$ para de materiais de pisos externos.

- Informações sobre desempenho térmico dos materiais: $70 \%$ já procuraram algum tipo de informação, sendo que a grande maioria buscou através de catálogos de fabricantes e fornecedores.

- Uso da cor: $66 \%$ associam o uso da cor a uma solução térmica.

- Uso de condicionadores de ar: somente $30 \%$ procuram evitar a utilização de aparelhos condicionadores.

- Fontes de consulta: $32 \%$ buscam fontes de consulta relacionadas ao conforto térmico, sendo a maioria através de catálogos de fabricantes e fornecedores.

O trabalho destaca que a questão da ventilação é muito pouco explorada devido à complexidade do estudo dos ventos, relativo a conhecimentos sobre mecânica dos fluidos. Foram também consideradas as dificuldades encontradas pelos profissionais assim como suas sugestões para que as mesmas possam ser superadas. Dentre as dificuldades apontadas pelos entrevistados estão os terrenos pequenos com orientações desfavoráveis, as edificações muito próximas, falta de interesse do cliente, custo alto de algumas soluções, falta de fontes de informação e falta de tempo. Como sugestões colocam maior facilidade na disponibilização de dados de vento e a necessidade de um planejamento urbano que contemple os aspectos do conforto ambiental no que se refere ao aumento de áreas verdes, orientação dos lotes e verticalização.

Chvatal (1998), conclui que os resultados mostram que uma parcela considerável de profissionais considera importante o conforto térmico natural, mas não fazem uso 
freqüente de ferramentas auxiliares. Coloca então a questão se isso reflete apenas o sentimento destes indivíduos em relação ao projeto e se na prática esses aspectos são realmente considerados.

Em estudo realizado por Maciel (2006), através de entrevistas com arquitetos brasileiros e europeus, traça-se um paralelo entre a atuação profissional no Brasil e em países que estão em estágio mais avançado no que diz respeito à incorporação dos conceitos de conforto térmico no processo de projeto. Além das limitações já vistas nos estudos apresentados anteriormente, Maciel aponta que um outro fator limitante aos arquitetos é a consciência dos construtores e incorporadores como clientes do arquiteto: como estes estão envolvidos apenas até a entrega da obra, suas prioridades envolvem economias imediatas, sem se preocupar com o desempenho pós-ocupação da edificação. A adoção de estratégias de condicionamento térmico natural, nestes casos, depende de maior criatividade do profissional em apontar soluções economicamente viáveis para o empreendedor, o que exige um alto grau de conhecimento e familiarização com os conceitos de conforto térmico (MACIEL, 2006).

Maciel ainda aborda a questão da legislação e dos códigos de edificação. Vários países europeus, como Alemanha e Reino Unido, possuem códigos de edificações que consideram o conforto térmico no ambiente construído. Os arquitetos entrevistados que atuam nestes países consideram os códigos muito influentes, embora não determinantes sobre a solução arquitetônica. Afirmam também que a presença das questões de conforto nos códigos estimula a integração de questões bioclimáticas no projeto e vêm influenciando na sensibilidade do mercado e dos profissionais quanto a estas questões nestes países. O tema educação também é abordado, sendo que todos os arquitetos entrevistados concordam que a educação tem um importante papel na atuação profissional, e defendem que as escolas devem assumir um compromisso ético para a disseminação e integração de questões ambientais nos cursos de arquitetura (MACIEL, 2006).

Ainda de acordo com Maciel (2006), apesar da comprovada vantagem de integrar os conceitos de condicionamento passivo no projeto de edificações, há uma dificuldade 
considerável em sua aplicação real, principalmente nos estágios iniciais de projeto, quando as principais soluções são definidas.

Pedrini e Szokolay (2004), ao apresentarem uma proposta que avalia desempenho térmico e consumo energético em edificações, defendem que a ferramenta deve ser utilizada nas primeiras fases do projeto arquitetônico, considerando as primeiras decisões como as mais importantes, ainda que sejam gerais. "Usualmente, arquitetos procuram por suporte na avaliação do desempenho da edificação durante a fase de detalhamento do projeto, quando há poucas possibilidades de mudanças" (PEDRINI e SZOKOLAY, 2004).

Ao apresentar a proposta de simulação como método de suporte às primeiras fases de projeto, os autores concluem ainda que a consulta deve ser rápida, transparente e educativa, pois se um procedimento toma muito tempo do processo de projeto, certamente será pouco utilizado pelos arquitetos.

Segundo MAHONEY (1971), as questões sobre condicionamento térmico devem ser consideradas em todas as fases do processo de projeto. A fase preliminar já deve considerar a relação do edifício com o clima local e assim prever posicionamento, volumetria e distribuição que se apropriem dos fatores positivos e minimizem os fatores negativos deste clima. $\mathrm{Na}$ fase de anteprojeto, devem ser previstos os materiais e técnicas de condicionamento passivo que contribuirão para o conforto térmico na edificação. Considerar estas questões apenas na fase final do processo de projeto pode levar à limitações de execução, minimizando o condicionamento térmico natural.

O desafio maior parece ser, justamente, o de transformar quantidades enormes de informações climáticas, disponíveis em estações meteorológicas, em dados de rápido consumo, ou seja, em ferramentas de trabalho práticas e ágeis. Em termos ideais, essa transmutação acontece com árduo trabalho de pesquisa, através de exaustivas análises, com auxílio de climatologistas, extraindo-se possíveis correlações úteis, produzindo-se critérios de projeto e, principalmente, através de 
uma muito bem desenvolvida representação gráfica que dê respostas quase que instantâneas aos questionamentos de seus consumidores: os profissionais da edificação (UBER, 1993).

De acordo com os estudos apresentados pôde-se constatar que além de haver uma parcela de profissionais que não se preocupam com as questões de conforto térmico, aqueles que se preocupam sofrem limitações das mais variadas ordens no processo de projeto.

Os estudos apontam uma lacuna entre a produção científica e a prática profissional decorrente da falta de intercambio entre o ambiente de pesquisa e o mercado, resultando num distanciamento das questões de conforto $\mathrm{n}$ prática do projeto arquitetônico. A reversão deste quadro depende de uma série de ações conjuntas que promovam a adoção de estratégias passivas de condicionamento nas edificações.

Dentre as necessidades apontadas pelos autores, destaca-se a carência de ferramentas de projeto que traduzam o conhecimento científico para a prática projetual, fornecendo recomendações de projeto para o local em questão. Tais ferramentas devem ser informativas, de fácil compreensão e utilização, auxiliando os profissionais na tomada de decisões sobre o conforto térmico ainda no estágio inicial do processo do projeto. Ainda que de maneira geral, estas recomendações subsidiam a correta adoção de estratégias de condicionamento térmico nos projetos. 


\section{O CONTEXTO DE RIBEIRÃO PRETO}

\subsection{ASPECTOS GERAIS}

O município de Ribeirão Preto situa-se na região nordeste do estado São Paulo, a $21^{\circ} 10^{\prime} 42^{\prime \prime}$ de latitude Sul e $47^{\circ} 48^{\prime} 42^{\prime \prime}$ de longitude Oeste, ocupando uma área de aproximadamente $651 \mathrm{~km}^{2}$. Os limites da cidade são dados pelos seguintes municípios: ao sul, Guatapará; a sudeste, Cravinhos; ao norte, Jardinópolis; a leste, Serrana; ao oeste, Dumont; a noroeste, Sertãozinho; e ao nordeste, Brodósqui. (CODERP, 2006). A cidade, com população estimada em 550 mil habitantes (IBGE, 2007), figura entre as mais importantes do Estado de São Paulo, constituindo um dos maiores centros financeiros do país devido à prosperidade econômica advinda, em grande parte, de sua dinâmica produtiva.

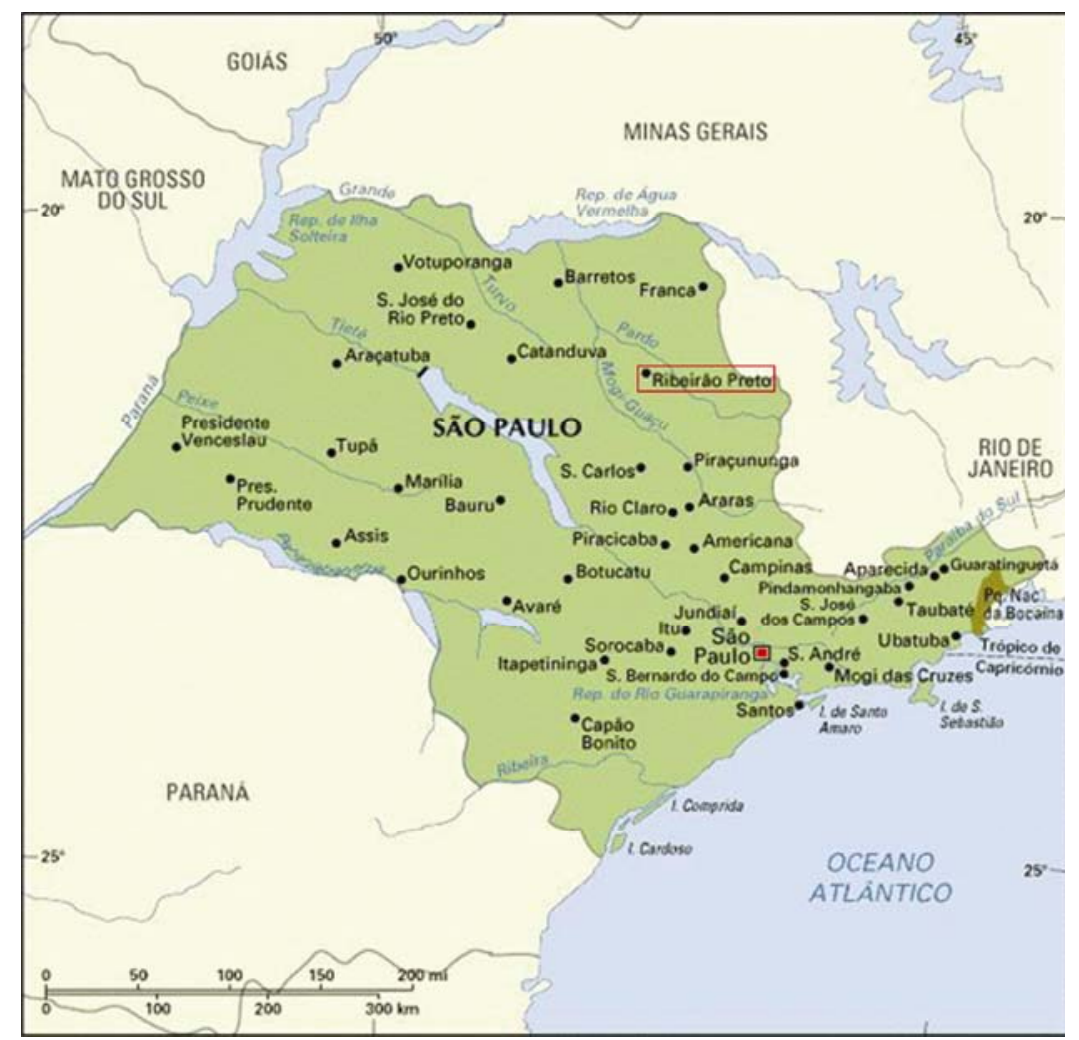

Figura 5. 1 Mapa do Estado de São Paulo com a localização de Ribeirão Preto. 



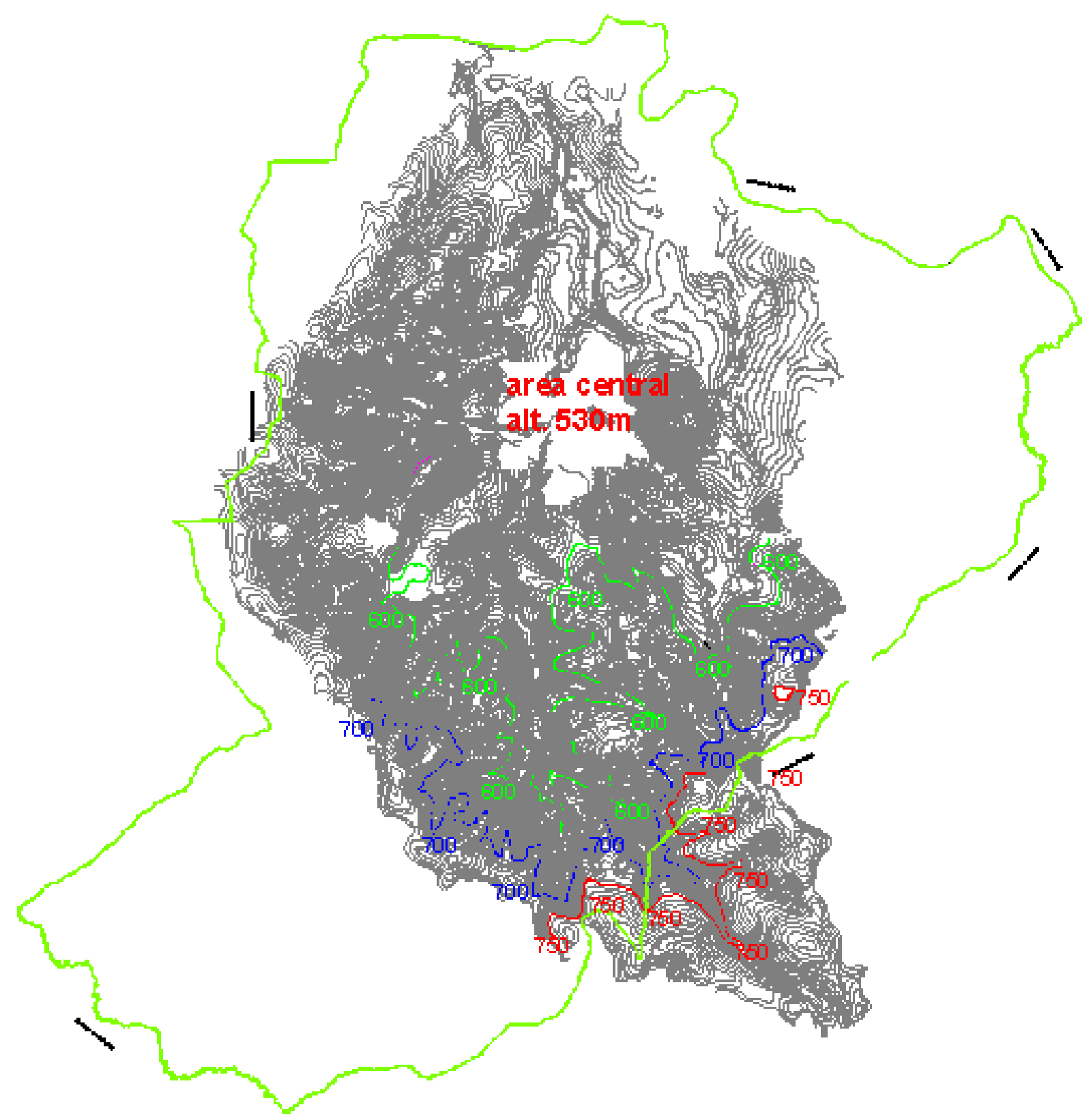

Figura 5. 2 Mapa topográfico de Ribeirão Preto (Secretaria de Obras). 



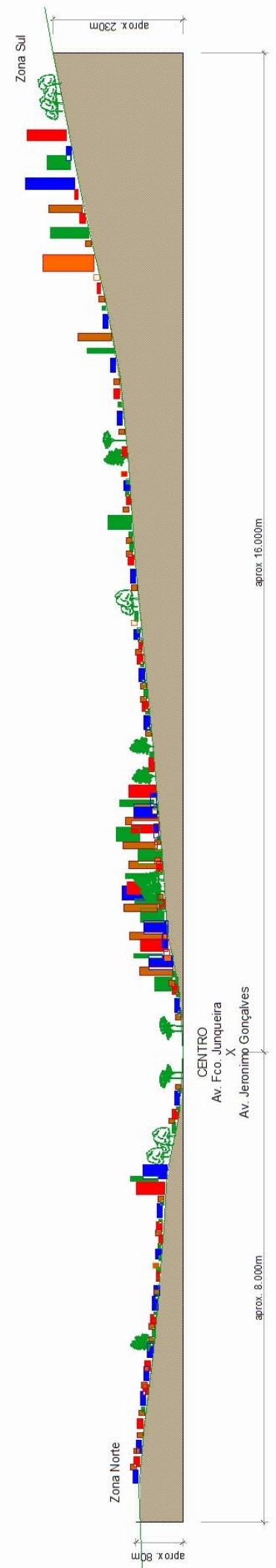

Figura 5. 3 Corte topográfico Norte/Sul de Ribeirão Preto (Secretaria de Obras). 

O relevo é suavemente ondulado, onde a região central encontra-se em área de fundo de vale, com altitudes em torno de 530 metros, e é circundada por áreas mais elevadas, chegando a 800 metros de altitude ao sudeste, na divisa com a cidade de Cravinhos.

Analisando o mapa topográfico (figura 5.2) e o corte (figura 5.3), pode-se ver na área mais baixa a região central, que possui ocupação mista com edificações baixas e altas, sendo estas em sua maioria com até oito pavimentos. Ao redor do centro ocorrem elevações em todas as direções geográficas, mas é nos sentidos sul, sudeste e sudoeste que estas ocorrem de maneira mais acentuada. Sabe-se que a direção predominante dos ventos na cidade é do quadrante sul. Portanto esta conformação do relevo prejudica a penetração dos ventos dominantes em grande parte da área urbana.

Quanto à vegetação natural, o município localiza-se em área de ocorrência de cerrado, sendo este mais rico nas áreas de basalto onde o solo (terra roxa) apresenta altos índices de produtividade (BLAT, 1997). A exploração da cultura cafeeira no inicio do século passado e a produção de cana de açúcar atualmente contribuíram para a derrubada de grande parte da vegetação natural, que hoje representa apenas $3 \%$ do território municipal.

O relevo característico da cidade, a substituição de áreas de vegetação natural por monoculturas e o aumento de áreas edificadas em detrimento de áreas verdes atuam como fatores modificadores das condições iniciais do clima. No caso de Ribeirão, estes fatores vêm contribuindo para o aumento de temperatura no microclima urbano. Além disto, de acordo com Guzzo (1999), verifica-se que os espaços livres urbanos de Ribeirão Preto além de mal distribuídos, em grande parte encontram-se vazios, uma vez que não foram arborizadas. A urgente efetivação dessas áreas por parte do poder público, através da implantação de arborização contribuirá significativamente para a melhoria da qualidade ambiental na cidade (GOMES; SOARES, 2003).

Segundo Dizeró (2006) e Silva (2004), nas últimas décadas a cidade vem passando por um significativo processo de expansão e adensamento da malha urbana. $\mathrm{Na}$ 
década de 90 a área central passou por um período de forte adensamento com a construção de muitos edifícios residenciais e um Shopping Center, além da expansão do comércio já existente. Algumas atividades presentes na área começaram a se transferir para outros locais da cidade, em especial a Zona Sul, que se transformou em uma área de pleno desenvolvimento. A partir de 2000 as áreas de maior crescimento da cidade são as Zonas Sul e Sudeste, concentrando atividades comerciais, de ensino e serviços além da expansão e desenvolvimento de novos bairros e condomínios residenciais (DIZERÓ, 2006). Na figura 5.4 podemos ver a rápida urbanização de duas grandes áreas da Zona Sul de Ribeirão Preto.

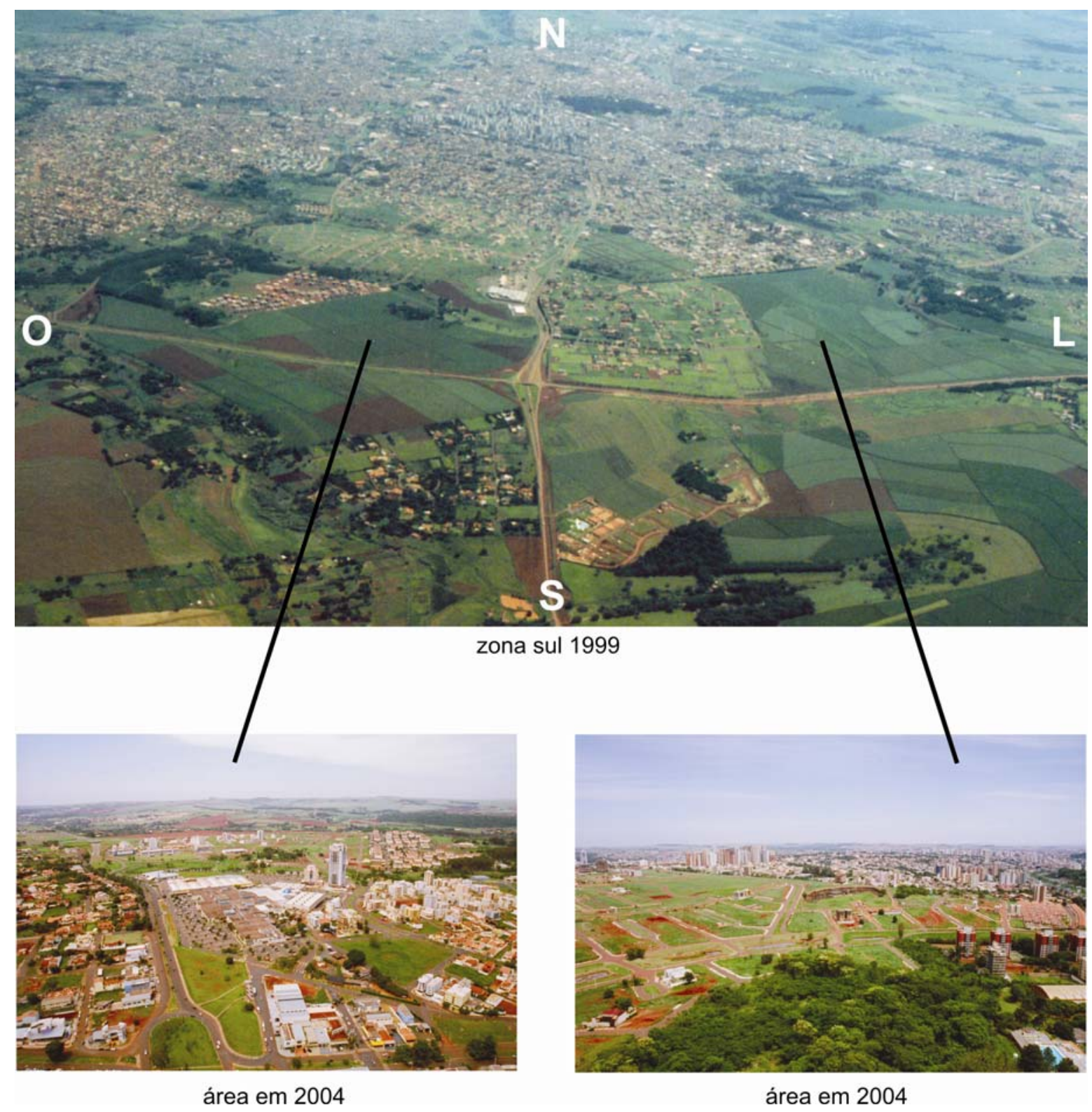

Figura 5. 4 Imagens da Zona Sul com expansão urbana em Ribeirão Preto (Tony Myasaka). 
A expansão direcionou-se essencialmente para a zona sul, caracterizando este como o vetor de crescimento da cidade nas últimas duas décadas. Trata-se de uma área nobre pelo dimensionamento dos lotes, padrão das edificações e pelo seu valor comercial. É também uma área privilegiada em relação à área central, pois além de ser pouco adensada devido às restrições de recuos locais, encontra-se em região mais elevada e, portanto, com melhores condições de temperatura e incidência de ventos.

\subsection{ASPECTOS CLIMÁTICOS}

Como já visto no capítulo anterior, Ribeirão Preto apresenta clima quente, semiúmido, inverno seco e verão chuvoso. A região é controlada por massas de ar equatorial, tropical, polar e em menor freqüência pela massa antártica. A atuação destas massas é responsável por alterações nas variáveis climáticas da cidade, refletida em grandes amplitudes térmicas verificadas entre o dia e a noite. Para melhor compreensão das particularidades do clima local, serão analisados a seguir os dados numéricos dos elementos climáticos na cidade.

Para obtenção dos dados climáticos foram contatadas três estações meteorológicas da cidade: a estação meteorológica do Instituto Agronômico (IAC), a estação meteorológica da Universidade de Ribeirão Preto (UNAERP) e a estação do Departamento de Aviação Civil (DAC). Na figura 5.5 temos a localização das três estações no mapa da cidade. 


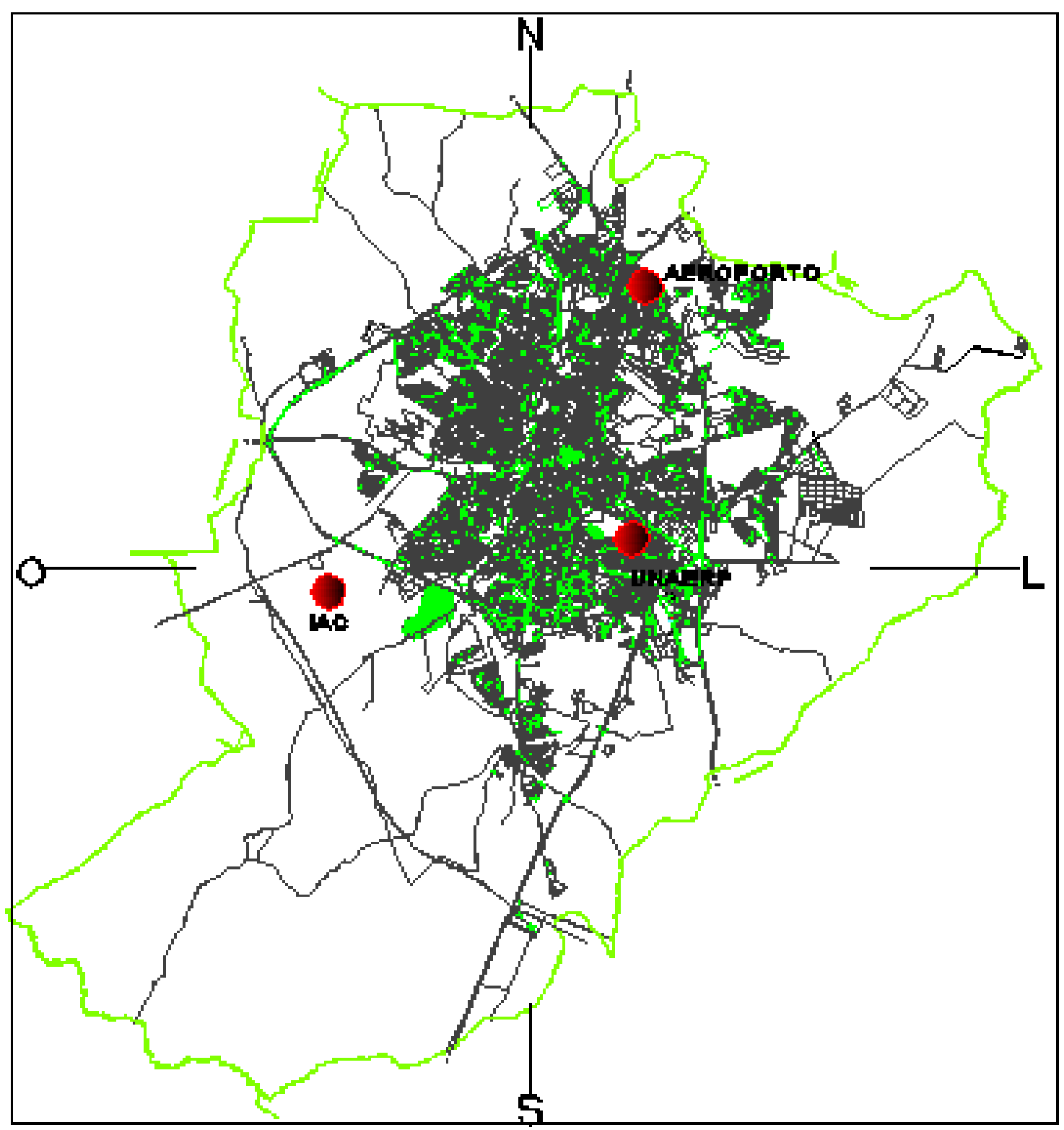

Figura 5. 5 Localização das Estações Meteorológicas no mapa de Ribeirão Preto. (AUTORA)

\subsubsection{Estação Meteorológica do DAC}

A estação do DAC situa-se a norte, junto ao Aeroporto Leite Lopes, latitude $21^{\circ} 08^{\prime} S$, longitude $47^{\circ} 46^{\prime} \mathrm{O}$, altitude $549 \mathrm{~m}$. Está inserida na malha urbana, porém em área descampada e sem edificações próximas. Foram disponibilizados pela estação apenas os dados sobre vento através de um anemograma de superfície (figura 5.6), que apresenta as médias das predominâncias de direção e velocidade do vento para 
o período de 1988 a 1992. Seria conveniente obter dados mensais, para que fossem analisadas as variações na ventilação entre os períodos quentes, frios, secos e úmidos. Porém, tais dados não foram disponibilizados.

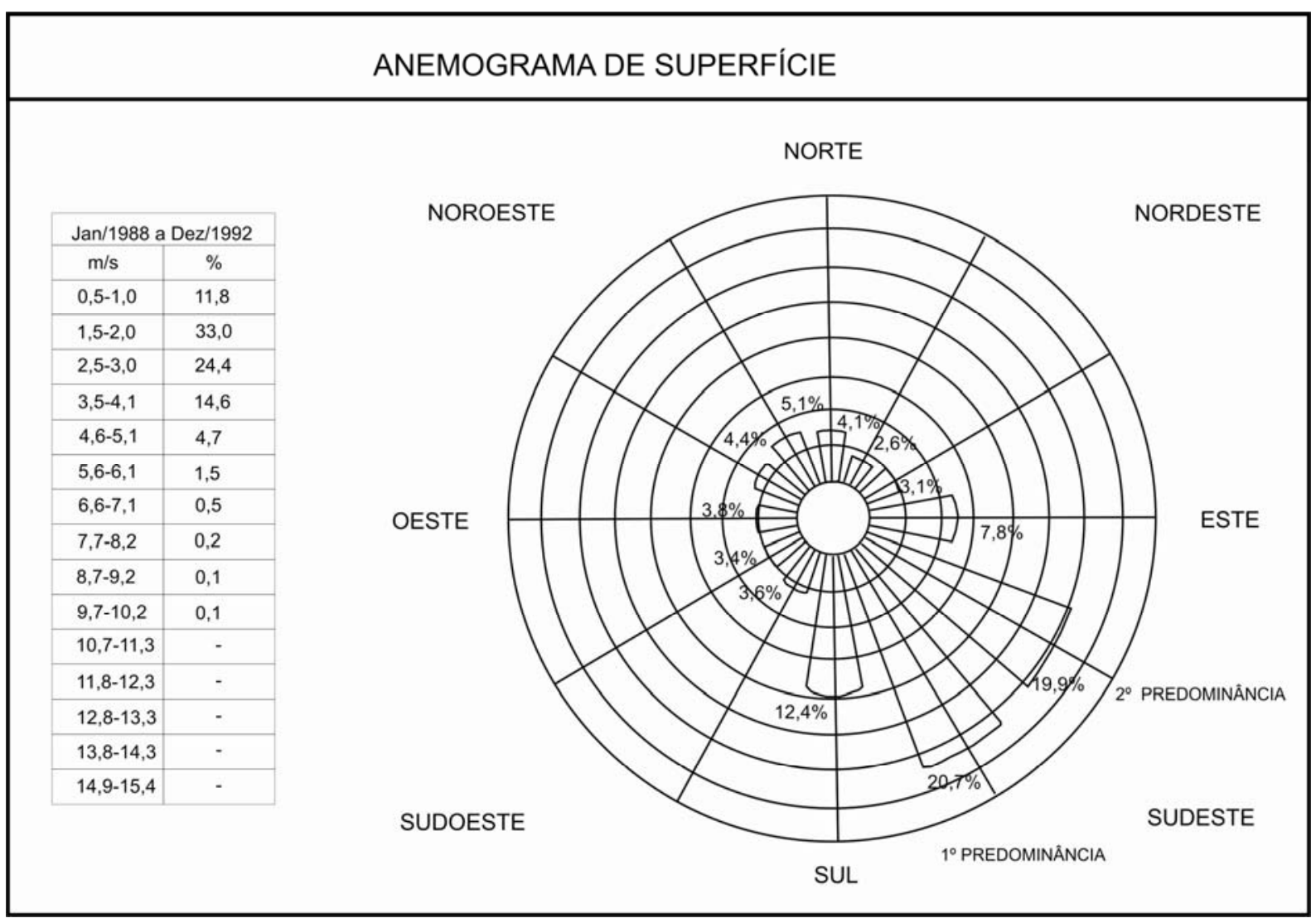

Figura 5. 6 Anemograma de Superfície (DAC Aeroporto Leite Lopes).

De acordo com o anemograma acima a primeira predominância é de Sul-Sueste com $20,7 \%$ de ocorrência e a segunda predominância é de Este - Sueste com 19,9\% de ocorrência, o que traduz que mais de $40 \%$ de ocorrência no quadrante sudeste. Quanto à velocidade a primeira predominância é de 1,5 a 2,0m/s com $33 \%$ de ocorrência e a segunda predominância é de 2,5 a 3,0m/s com 24,4\% de ocorrência.

\subsubsection{Estação Meteorológica do IAC}

A estação meteorológica do IAC está localizada a sudeste, junto à Estação Experimental de Ribeirão Preto, latitude $21^{\circ} 13^{\prime}$ S, longitude $48^{\circ} 54^{\prime} \mathrm{O}$, altitude $562 \mathrm{~m}$. 
O formato dos dados climatológicos cedidos pela estação segue o padrão das normais climatológicas e referem-se ao período de 1955 a 1998.

Tabela 5.1 - Dados climáticos de Ribeirão Preto - Estação Meteorológica do IAC

\begin{tabular}{|l|l|l|l|l|l|l|l|l|l|l|l|l|}
\hline & JAN & FEV & MAR & ABR & MAIO & JUN & JUL & AGO & SET & OUT & NOV & DEZ \\
\hline MAX ABS ${ }^{\circ} \mathrm{C}$ & 33,5 & 33,5 & 33,4 & 32,0 & 30,4 & 29,7 & 30,4 & 33,6 & 35,2 & 35,3 & 34,5 & 33,7 \\
\hline MED MAX ${ }^{\circ} \mathrm{C}$ & 29,9 & 30,3 & 30,2 & 29,1 & 27,0 & 26,1 & 26,7 & 29,0 & 30,3 & 30,4 & 30,1 & 29,5 \\
\hline MIN ABS ${ }^{\circ} \mathrm{C}$ & 15,8 & 16,1 & 14,7 & 11,8 & 8,1 & 5,8 & 5,8 & 7,3 & 10,0 & 12,3 & 13,3 & 14,8 \\
\hline MED MIN $^{\circ} \mathrm{C}$ & 18,7 & 18,6 & 17,9 & 16,1 & 13,5 & 12,1 & 11,9 & 13,5 & 15,6 & 17,0 & 17,6 & 18,4 \\
\hline MEDIAS ${ }^{\circ} \mathrm{C}$ & 24,3 & 24,4 & 24,0 & 22,6 & 20,3 & 19,1 & 19,3 & 21,2 & 22,9 & 23,7 & 23,9 & 24,0 \\
\hline UMID REL $\%^{8}$ & 80,5 & 81,1 & 80,2 & 73,2 & 74,4 & 70,5 & 64,9 & 57,1 & 62,2 & 68,4 & 73,6 & 80,3 \\
\hline CHUVAS mm $^{260,2}$ & 217,7 & 163,4 & 82,8 & 60,4 & 31,8 & 24,4 & 25,7 & 57,1 & 136,9 & 173,1 & 285,9 \\
\hline VEN VEL m/s & 1,6 & 1,4 & 1,3 & 1,5 & 1,4 & 1,4 & 1,8 & 2,0 & 2,3 & 2,3 & 2,2 & 1,9 \\
\hline VEM DIR & NW & SE & SE & SE & SE & SE & SE & SE & SE & SE & SE & SE \\
\hline
\end{tabular}

\subsubsection{Estação Meteorológica da UNAERP}

A estação meteorológica da UNAERP está localizada a leste, latitude $21^{\circ} 11^{\prime} S$, longitude $47^{\circ} 46^{\prime} \mathrm{O}$, altitude $570 \mathrm{~m}$. Está inserida na malha urbana em área edificada. Estes dados compreendem o período entre 2000 e 2006 e contêm médias referentes a dez parâmetros climáticos, incluindo dados de radiação solar máxima. Foram obtidos também dados diários, com medições a cada 30 minutos, para os anos de 2000 a 2006.

Tabela 5.2 - Dados climáticos de Ribeirão Preto - Estação Meteorológica da UNAERP

\begin{tabular}{|l|l|l|l|l|l|l|l|l|l|l|l|l|}
\hline & JAN & FEV & MAR & ABR & MAIO & JUN & JUL & AGO & SET & OUT & NOV & DEZ \\
\hline MAX ABS ${ }^{\circ} \mathrm{C}$ & 33,1 & 33,1 & 32,9 & 32,0 & 30,8 & 29,2 & 30,4 & 32,7 & 35,1 & 35,4 & 34,1 & 33,0 \\
\hline MED MAX ${ }^{\circ} \mathrm{C}$ & 24,4 & 24,4 & 24,6 & 24,1 & 20,5 & 20,5 & 20,3 & 22,5 & 23,5 & 24,7 & 24,3 & 24,3 \\
\hline MIN ABS $^{\circ} \mathrm{C}$ & 18,1 & 17,8 & 17,9 & 15,6 & 9,5 & 10,1 & 8,9 & 10,6 & 10,6 & 15,3 & 14,7 & 17,6 \\
\hline MED MIN $^{\circ} \mathrm{C}$ & & & & & & & & & & & & \\
\hline MEDIAS $^{\circ} \mathrm{C}$ & 24,1 & 24,2 & 24,4 & 23,8 & 20,2 & 20,3 & 20,0 & 22,1 & 23,1 & 24,4 & 24,0 & 24,0 \\
\hline UMID REL $\%^{79,9}$ & 79,8 & 76,9 & 68,9 & 70,7 & 65,7 & 60,2 & 51,2 & 58,0 & 64,6 & 72,4 & 78,8 \\
\hline $\mathrm{CHUVAS} \mathrm{mm}^{276,4}$ & 226,3 & 109,9 & 51,4 & 61,2 & 13,5 & 12,7 & 11,7 & 38,1 & 92,7 & 184,1 & 258,0 \\
\hline RADIAÇÃO & 1226,7 & 1179,2 & 1142,7 & 959,0 & 836,0 & 750,5 & 784,8 & 879,7 & 993,8 & 1082,8 & 1181,2 & 1175,0 \\
\hline VEN VEL m/s & 1,5 & 1,0 & 1,1 & 1,3 & 1,2 & 1,0 & 1,3 & 1,5 & 2,5 & 1,5 & 1,3 & 1,2 \\
\hline VEM DIR & ESE & ESE & ESE & ESE & SE & ESE & ESE & ESE & ESE & ESE & ESE & ESE \\
\hline
\end{tabular}




\subsubsection{Considerações Sobre os Dados}

Ao observar os dados da UNAERP (tabela 5.2), detectou-se que as Médias das Temperaturas Máximas estão cerca de $5^{\circ} \mathrm{C}$ abaixo dos valores apresentados pela estação do IAC (tabela 5.1). Além disto, estes valores são muito próximos aos valores das Temperaturas Médias. Sabe-se que as Temperaturas Médias são médias aritméticas entre os valores das Médias das Máximas e Médias das Mínimas, logo os dois valores não poderiam ser tão próximos. Isto também pôde ser comprovado através da observação dos dados diários fornecidos pela mesma estação. Concluiu-se que há alguma divergência entre o método de cálculo das Médias das Máximas desta estação e do método utilizado pelas estações que apresentam as normais climatológicas, como a estação do IAC. Este fator impossibilita a utilização de suas médias neste trabalho. Por este motivo, para aplicação do Método de Mahoney serão então utilizados os dados da estação do IAC.

Porém, considera-se de grande importância a observação dos dados diários fornecidos pela UNAERP, no sentido de avaliar ocorrências relevantes no comportamento dos dados, que não são mostradas através de valores médios, como o caso da Umidade Relativa. Além disto, os dados diários de temperatura da UNAERP serão utilizados para analises entre radiação e temperatura do ar no capítulo 7 deste trabalho.

Para utilização de duas fontes diferentes de dados neste trabalho seria conveniente um comparativo numérico entre ambas. Porém este comparativo seria um equívoco, pois os equipamentos das duas estações são diferentes e não estão calibrados entre si. Assim, foi feita uma comparação qualitativa entre as duas estações (tabela 5.3) no sentido de averiguar o grau de semelhança no comportamento dos dados climáticos ao longo do ano. 
Tabela 4.3 - Comparação qualitativa entre dados climáticos da s estações do IAC e UNAERP.

\begin{tabular}{|c|c|c|}
\hline Dados climáticos / Fonte & \begin{tabular}{|l|} 
IAC \\
$1955-1998$
\end{tabular} & $\begin{array}{l}\text { UNAERP } \\
2000-2006\end{array}$ \\
\hline $\begin{array}{l}\text { Meses com maior Média das } \\
\text { Máximas }\end{array}$ & $\begin{array}{l}\text { Fevereiro e Setembro }-30,3^{\circ} \mathrm{C} \\
\text { Outubro }-30,4^{\circ} \mathrm{C}\end{array}$ & $\begin{array}{l}\text { Março }-24,6^{\circ} \mathrm{C} \\
\text { Outubro }-24,7^{\circ} \mathrm{C}\end{array}$ \\
\hline $\begin{array}{l}\text { Meses com menor Media das } \\
\text { Mínimas }\end{array}$ & $\begin{array}{l}\text { Julho }-11,9^{\circ} \mathrm{C} \\
\text { Junho }-12,1^{\circ} \mathrm{C}\end{array}$ & Não há dados \\
\hline Media de Precipitação anual & $1519,4 \mathrm{~mm}$. & $1335,9 \mathrm{~mm}$. \\
\hline $\begin{array}{l}\text { Meses com maior índice de } \\
\text { precipitação }\end{array}$ & $\begin{array}{l}\text { Dezembro - 285,9mm. } \\
\text { Janeiro - 260,2 mm. }\end{array}$ & $\begin{array}{l}\text { Janeiro - 276,4 mm. } \\
\text { Dezembro - 258,0 mm. }\end{array}$ \\
\hline Media Umidade anual & $72,2 \%$ & $68,9 \%$ \\
\hline $\begin{array}{l}\text { Meses secos } \\
\text { (chuvas abaixo de } 60 \mathrm{~mm} \text { ) }\end{array}$ & $\begin{array}{l}\text { Junho, Julho } \\
\text { Agosto, Setembro }\end{array}$ & $\begin{array}{l}\text { Junho, Julho } \\
\text { Agosto, Setembro }\end{array}$ \\
\hline $\begin{array}{l}\text { Meses secos } \\
\text { (UR abaixo de } 70 \%)\end{array}$ & $\begin{array}{l}\text { Julho, Agosto, } \\
\text { Setembro, Outubro }\end{array}$ & $\begin{array}{l}\text { Junho, Julho, Agosto, } \\
\text { Setembro, Outubro }\end{array}$ \\
\hline $\begin{array}{l}\text { Meses mais úmidos } \\
\text { (chuvas acima de } 150 \mathrm{~mm} \text { ) }\end{array}$ & $\begin{array}{l}\text { Novembro, Dezembro, Janeiro, } \\
\text { Fevereiro e Março }\end{array}$ & $\begin{array}{l}\text { Novembro, Dezembro, Janeiro } \\
\text { e Fevereiro }\end{array}$ \\
\hline $\begin{array}{l}\text { Meses mais úmidos } \\
\text { (UR acima de 78\%) }\end{array}$ & $\begin{array}{l}\text { Dezembro, Janeiro, } \\
\text { Fevereiro e Março }\end{array}$ & $\begin{array}{l}\text { Dezembro, Janeiro, } \\
\text { Fevereiro e Março }\end{array}$ \\
\hline $\begin{array}{l}\text { Mês mais quente e } \\
\text { úmido }\end{array}$ & $\begin{array}{l}\text { Dezembro } \\
\text { Max }-33,7^{\circ} \mathrm{C}, \quad \text { UR80, 2\%, } \\
\text { Chuvas } 285,9 \mathrm{~mm}\end{array}$ & $\begin{array}{l}\text { Janeiro } \\
\text { Max }-24,4^{\circ} \mathrm{C}, \quad \text { UR79, } 9 \%, \\
\text { Chuvas } 276,4 \mathrm{~mm}\end{array}$ \\
\hline $\begin{array}{l}\text { Mês mais quente e } \\
\text { seco }\end{array}$ & $\begin{array}{l}\text { Setembro } \\
\text { Max }-30,3^{\circ} \mathrm{C}, \quad \text { UR62, } 2 \% \text {, } \\
\text { Chuvas } 57,1 \mathrm{~mm}\end{array}$ & $\begin{array}{l}\text { Outubro } \\
\begin{array}{l}\text { Max }-24,4^{\circ} \mathrm{C}, \quad \text { UR64, } 6 \%, \\
\text { Chuvas } 92,7 \mathrm{~mm}\end{array}\end{array}$ \\
\hline $\begin{array}{l}\text { Ventos } \\
\text { Predominantes }\end{array}$ & SE & ESE \\
\hline Ventos: Velocidade & $1,8 \mathrm{~m} / \mathrm{s}$ & $1,4 \mathrm{~m} / \mathrm{s}$ \\
\hline $\begin{array}{l}\text { Ventos: Período quente e } \\
\text { seco (Set./ Out./ Nov) }\end{array}$ & $\begin{array}{l}\text { SE, com velocidade de } 2,0 \mathrm{~m} / \mathrm{s} \\
\text { a } 2,3 \mathrm{~m} / \mathrm{s}\end{array}$ & $\begin{array}{l}\text { ESE, com velocidade de } 1,5 \mathrm{~m} / \mathrm{s} \\
\text { a } 2,5 \mathrm{~m} / \mathrm{s}\end{array}$ \\
\hline $\begin{array}{l}\text { Ventos: Período quente e } \\
\text { chuvoso (Dez./ Jan./ Fev) }\end{array}$ & $\begin{array}{l}\text { SE, com velocidade de } 1,3 \mathrm{~m} / \mathrm{s} \\
\text { a } 1,9 \mathrm{~m} / \mathrm{s}\end{array}$ & $\begin{array}{l}\text { ESE, com velocidade de } 1,0 \mathrm{~m} / \mathrm{s} \\
\text { a } 1,5 \mathrm{~m} / \mathrm{s}\end{array}$ \\
\hline
\end{tabular}


De acordo com a tabela 4.3, vê-se que a maioria dos dados tem comportamento semelhante nas duas estações. Em ambas mais de $50 \%$ das chuvas ocorrem nos meses de Dezembro, Janeiro e Fevereiro. Os meses mais chuvosos são Dezembro e Janeiro e os mais secos são Julho, Agosto, Setembro e Outubro. O mesmo ocorre com a umidade relativa: as mais baixas são registradas em Julho, Agosto, Setembro e Outubro e as mais altas em Dezembro, Janeiro, Fevereiro e Março. Os ventos predominantes são do mesmo quadrante e com velocidades médias próximas, sendo que as velocidades maiores registradas na estação do IAC podem ser resultantes de sua localização fora da malha urbana. Em ambas também ocorre uma diminuição na velocidade dos ventos no período quente e chuvoso em relação ao período quente e seco. Em relação as Média das Máximas, ocorre um "atraso" na tabela da UNAERP, onde o mês mais quente e úmido é Janeiro e o mês mais quente e seco é Outubro, enquanto que na tabela do IAC o mês mais quente e úmido é Dezembro e o mês mais quente e seco é Setembro.

Apesar de alguma diferença entre a ocorrência das temperaturas máximas, os outros elementos permitem concluir que há semelhança qualitativa entre os dados das duas estações, o que se julgou suficiente para justificar a utilização de dados de estações diferentes na metodologia deste trabalho.

\subsection{LEGISLAÇÃO CONSTRUTIVA}

O Código de Obras de uma cidade tem o importante papel de regulamentar e legislar a ocupação e as construções de uma cidade e também de informar os profissionais que ao desenvolverem um projeto frequentemente o utilizam como material de consulta. Uma vez que nele constam leis com parâmetros construtivos para edificações, é de se esperar que estas leis estejam baseadas em estudos aprofundados e voltados para a cidade em questão, levando em conta suas peculiaridades. Assim, em relação aos parâmetros relacionados às questões de conforto térmico, devem ser consideradas as condições climáticas que caracterizam a cidade em questão. 
O Manual do Código de Obras é um instrumento de democratização da informação. Surgiu da união dos esforços dos órgãos da Administração Municipal com a Associação de Engenharia, Arquitetura e Agronomia de Ribeirão Preto (AEAARP), para que os profissionais da área da construção civil tenham em mãos todas as regras e normas de processos construtivos [...]. Temos hoje em Ribeirão um instrumento legítimo que serve inclusive como ponto de partida para discussões críticas quando se fala em normatização do processo construtivo (PMRP, 1996).

O atual Código de Obras de Ribeirão Preto é baseado no decreto estadual 12.342/78, que dispõe sobre o Código Sanitário do estado de São Paulo. A seguir, são abordados os artigos presentes no Código que influenciam no conforto térmico das edificações.

O decreto 12.342 de 27/09/1978, primeira parte, Livro III, Título II, Capítulo II, que dispõe sobre insolação, ventilação e iluminação em edificações:

Artigo 44 - a área iluminante dos compartimentos deverá corresponder no mínimo a:

I - Nos locais de trabalho e nos destinados a ensino, leitura e atividades similares: $1 / 5$ da área do piso;

II - Nos compartimentos destinados a dormir, estar, cozinhar, comer e em compartimentos sanitários: $1 / 8$ da área do piso, com o mínimo de 0,60m²

III - Nos demais tipos de compartimentos: 1/8 da área do piso, com o mínimo de $0,60 \mathrm{~m}^{2}$;

Artigo 45 - A área de ventilação natural deverá ser em qualquer caso de, no mínimo, a metade da superfície de iluminação natural.

Os artigos admitem então que um dormitório ou sala tenha como iluminação natural $12,5 \%$ de sua área de piso e que metade desta, ou seja, 6,25\% de área de piso de ventilação natural. Fazem referencia apenas aos tamanhos das aberturas sem considerar o posicionamento, formato e sistema de abertura destas.

No Capítulo III, que dispõe sobre especificações construtivas gerais temos: 
Artigo 51 - As paredes terão espessuras e revestimentos suficientes a atender às necessidades de resistência, isolamento térmico, acústico e impermeabilidade segundo sua posição e os materiais nela empregados.

O artigo acima propõe uma preocupação em relação ao isolamento térmico. Porém não menciona quais condições deveriam ser adotadas para servir de parâmetros no momento da especificação dos materiais nem indica quais seriam os materiais mais apropriados para se atender às necessidades citadas.

Há ainda a lei 2442 de 05/03/1971 que diz: "[...] fica estabelecida a obrigatoriedade da instalação de aparelhos de ar condicionado em todos os cinemas e teatros do Município - a serem instalados e de categoria de luxo."

A partir da análise dos artigos fica claro que, os parâmetros de dimensionamento para iluminação e ventilação refletem uma preocupação apenas com a salubridade mínima do ambiente, uma vez que o Código baseia-se em antiga lei sanitarista. A Coordenadoria de Desenvolvimento de Ribeirão Preto (CODERP) foi consultada sobre possíveis atualizações de leis e decretos que tivessem influência na questão do conforto térmico das edificações. Porém não existem atualizações neste sentido.

$\mathrm{Na}$ Associação de Engenharia, Arquitetura e Agronomia de Ribeirão Preto (AEAARP) há o Fórum Permanente de Debates "Ribeirão Preto do Futuro", núcleo consultivo da Associação e é aberto à participação de profissionais de arquitetura e engenharia da cidade. No ano de 2006, o fórum propôs um debate sobre a atualização do Código de Obras da Cidade. A seguir, trecho da entrevista de Newton Bonagamba, engenheiro do Departamento de Obras e Serviços Particulares da Divisão de Análise de Projetos da Secretaria de Planejamento e Infra-estrutura, ao jornal A Cidade, de 06 de abril de 2006, em ocasião do debate:

"Ribeirão Preto precisa de um Código de Obras próprio. Nos últimos seis anos, já o enviamos duas vezes à Câmara, mas seu processo de aprovação não teve uma continuidade. Ele é de fundamental importância para a cidade, pois define regras para se fazer edificações." - Newton Bonagamba (A CIDADE, 2006). 
Neste debate não houve discussão sobre as questões do conforto térmico, mas, o fórum de debates está aberto a novas propostas e discussões sobre o Código de Obras do município. Seria pertinente fomentar a discussão sobre o conforto térmico no ambiente construído nos próximos debates visando a inclusão de algumas diretrizes de conforto, tendo em vista a importância desta questão perante as condições climáticas da cidade.

\subsection{EDIFICAÇÕES E CONFORTO TÉRMICO NA CIDADE}

Apesar do clima quente, a cidade de Ribeirão Preto carece de estudos e pesquisas sobre clima e conforto térmico do ambiente construído na cidade. Foi encontrado apenas um trabalho científico abordando assunto em Ribeirão Preto, que analisa plantas de edifícios multifamiliares e simula as condições de conforto térmico de seus ambientes através do sotware Arquitrop (ACOSTA, 2002).

Não é foco deste trabalho, analisar edificações. Porém, propõe-se neste capítulo uma análise qualitativa de algumas edificações na cidade no sentido de contribuir para uma reflexão sobre a prática do projeto arquitetônico na cidade e sobre a relação dos profissionais com o conforto térmico. Para esta análise qualitativa foram escolhidas aleatoriamente edificações das quais se tivesse acesso a informações através do projeto, visitas, entrevistas ou publicações, que subsidiassem uma crítica positiva ou negativa do ponto de vista do conforto térmico no ambiente construído. É válido ressaltar que houve certa dificuldade em encontrar exemplares que tivessem uma relação positiva com as questões de conforto térmico e o clima da cidade.

\subsubsection{Residência Eduardo Lousada}


O arquiteto Roberto Scatena, falecido na década de 80 , teve contato com as questões de conforto térmico durante seu mestrado na Universidade da Califórnia, onde pesquisou a contribuição das torres de ventilação para o condicionamento térmico natural. Retornando a Ribeirão, projetou esta residência para familiares seus utilizando alguns dos conhecimentos adquiridos.

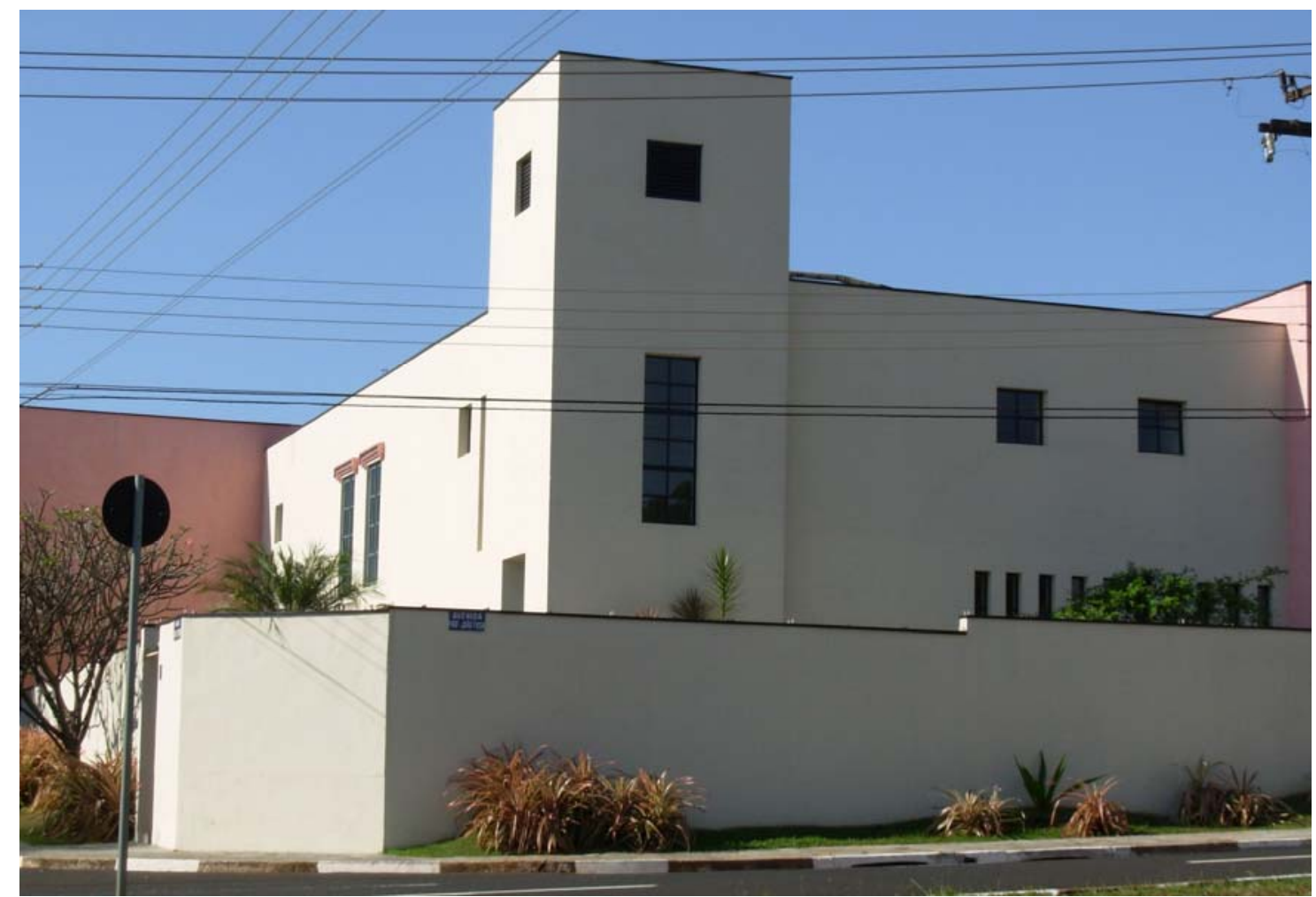

Figura 5. 7 Fachadas da residência Eduardo Lousada. (Autora)

A residência possui uma torre de ventilação que capta os ventos dominantes na sua parte superior (figuras 5.7 e 5.8). Através de dutos, o ar captado vai ao térreo, passa por caixas de pedra subterrâneas, sendo resfriado e então insuflado para os ambientes internos através de grelhas. 


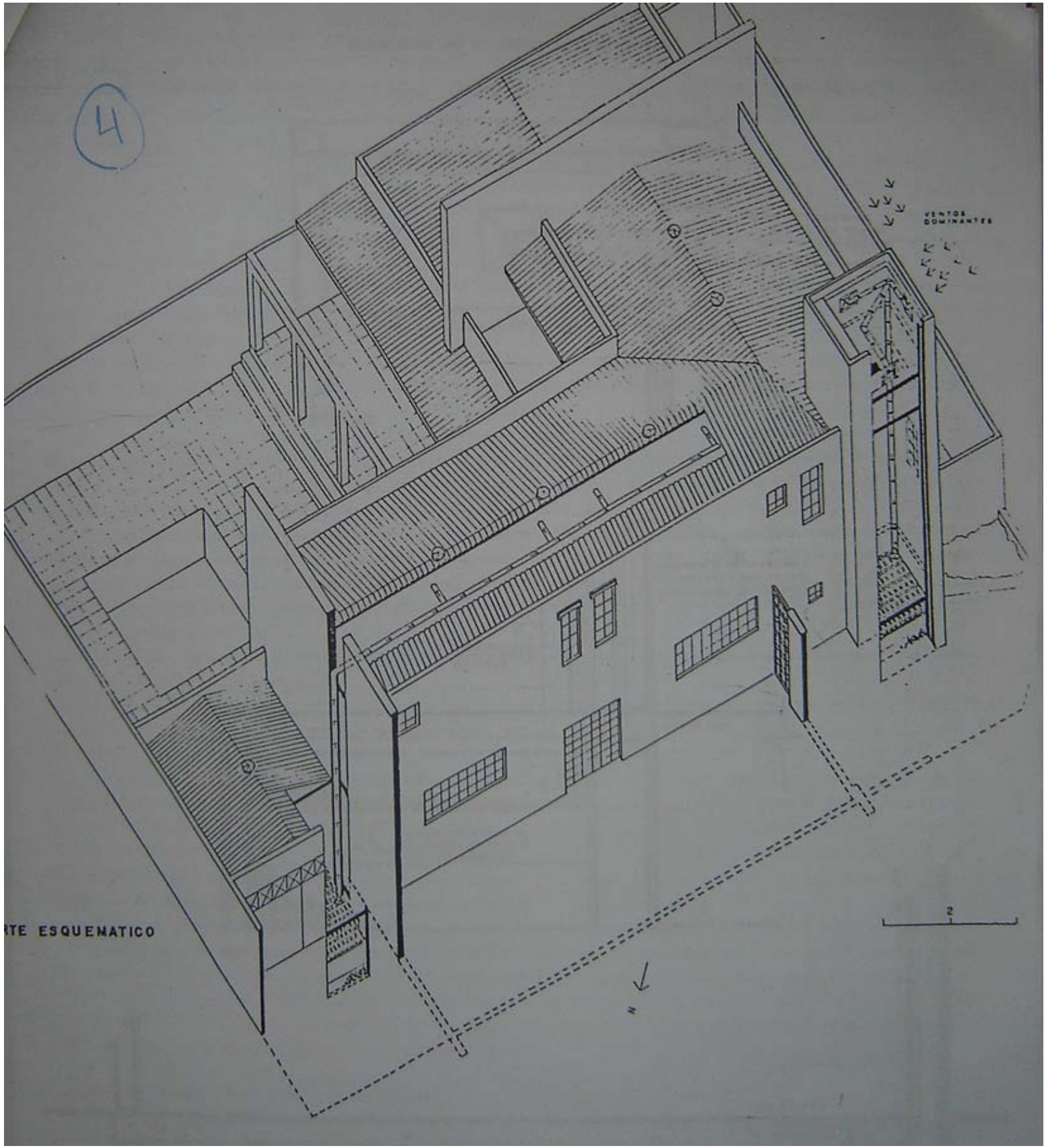

Figura 5. 8 Perspectiva com detalhe da torre de ventilação. (Arquivo do proprietário)

Além disso, há um pátio interno, para onde os ambientes possuem aberturas, que auxilia na ventilação cruzada. As paredes externas que recebem insolação durante a tarde são duplas, com isolamento e pintadas com cor clara para minimizar a absorção do calor. 


\subsubsection{Edifício Place des Vosges}

Este edifício de apartamentos está localizado na Avenida João Fiúsa, corredor de edifícios residenciais na Zona Sul da cidade. Trata-se de área elevada e pouco adensada, onde quadras de 150×150 metros são divididas em apenas seis lotes para edifícios altos e é circundada por áreas onde a verticalização é vetada. Esta configuração maior flexibilidade para a implantação e orientação e favorece o aproveitamento da ventilação natural. A planta do edifício (figura 5.9) mostra a área social circundada pela grande sacada, orientada a norte e oeste. Neste caso, devido à orientação, a sacada não impede a penetração direta do sol nas salas no período da tarde.

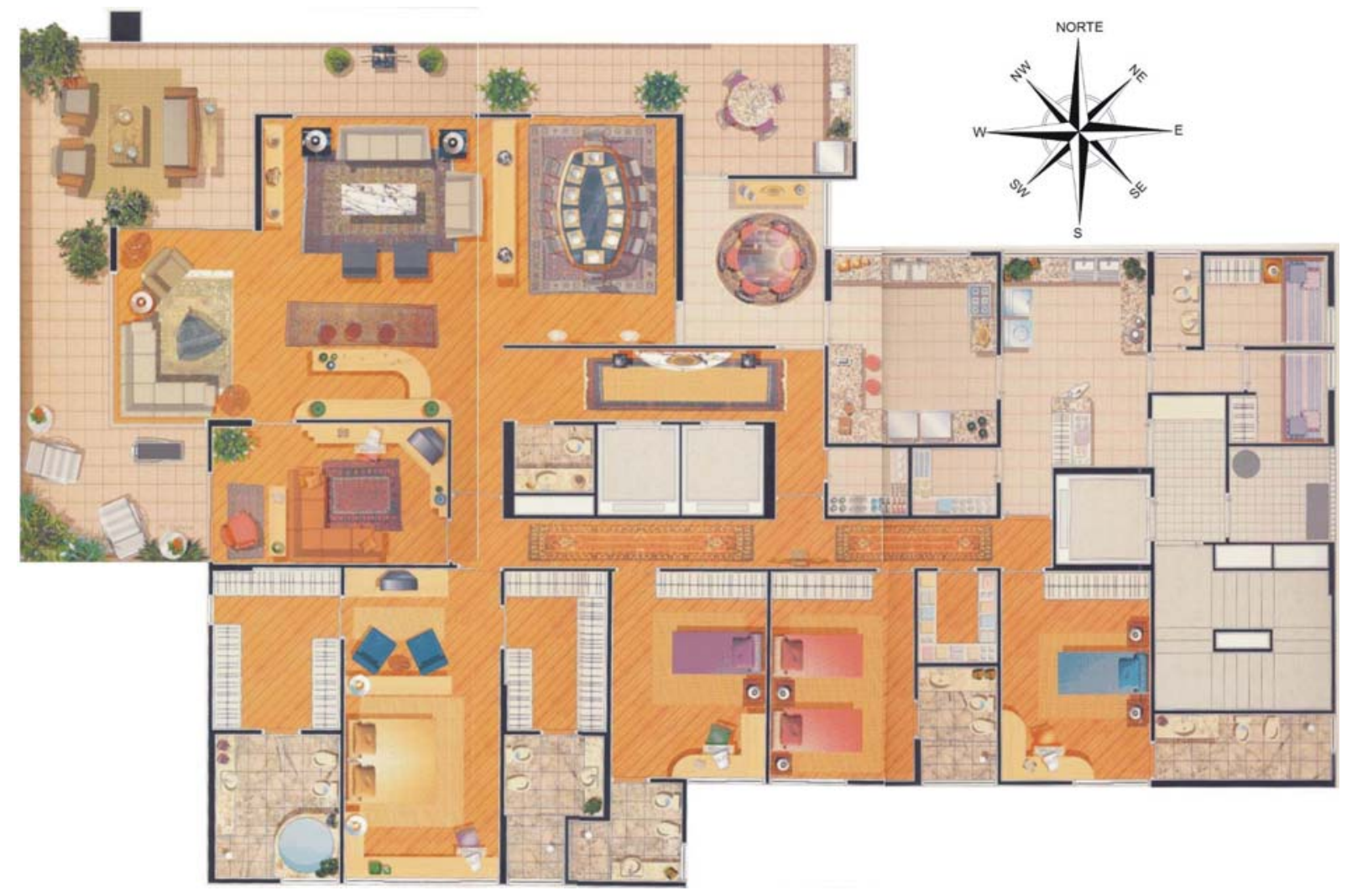

Figura 5. 9 Planta Edifício Place des Vosges. (Construtora Copema)

De acordo com moradores, a solução encontrada pelos condôminos foi a utilização de toldos, como se vê na foto tirada no mês de julho às 15h30minh (figura 5.10), que ajudou a amenizar a questão da radiação direta. Porém, as salas, que possuem 
grandes aberturas somente para a sacada, ficam com a ventilação prejudicada quando os toldos estão fechados. Além disto, a orientação destes ambientes não favorece a penetração dos ventos dominantes.

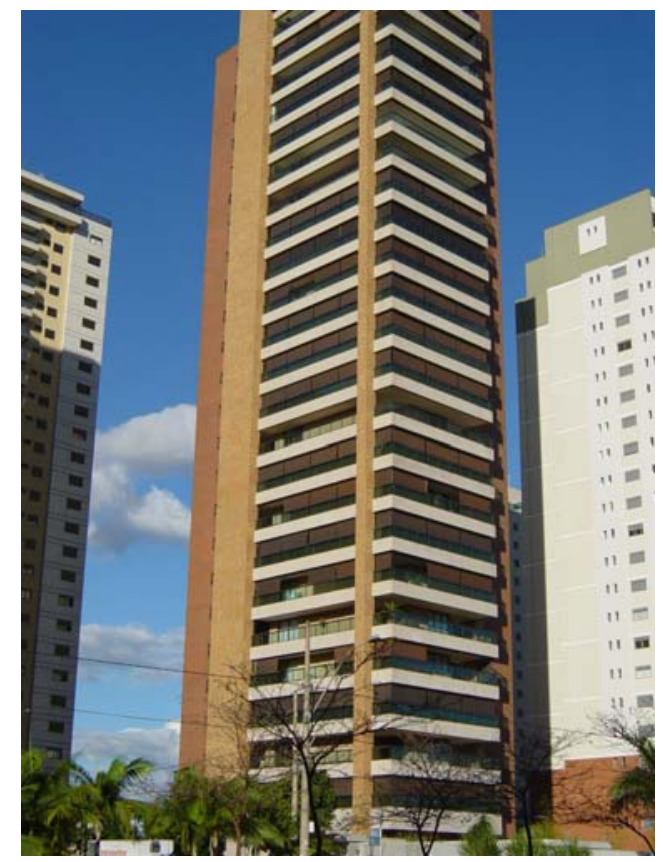

Figura 5. 10 Fachadas Norte e Oeste Edifício Place des Vosges. (Autora)

As dimensões das aberturas dos demais ambientes atendem ao Código de Obras, mas devido ao sistema de abertura de correr, a área efetiva de ventilação e iluminação fica reduz-se a $50 \%$ da área do caixilho.

\subsubsection{Campus da Universidade Paulista - UNIP}

O campus da UNIP, projeto do arquiteto Luis César Barillari, está localizado na Zona Sul próximo a Rodovia Ribeirão Preto - Bonfim Paulista. É composto por três edifícios retangulares e alongados, estando as fachadas maiores voltadas para nordeste e sudoeste. No edifício 1 (figura 5.11), estas fachadas são protegidas por "brise-soleil" móveis afastados do corpo principal, o que protege da insolação direta e permite a ventilação natural (figura 5.12). 


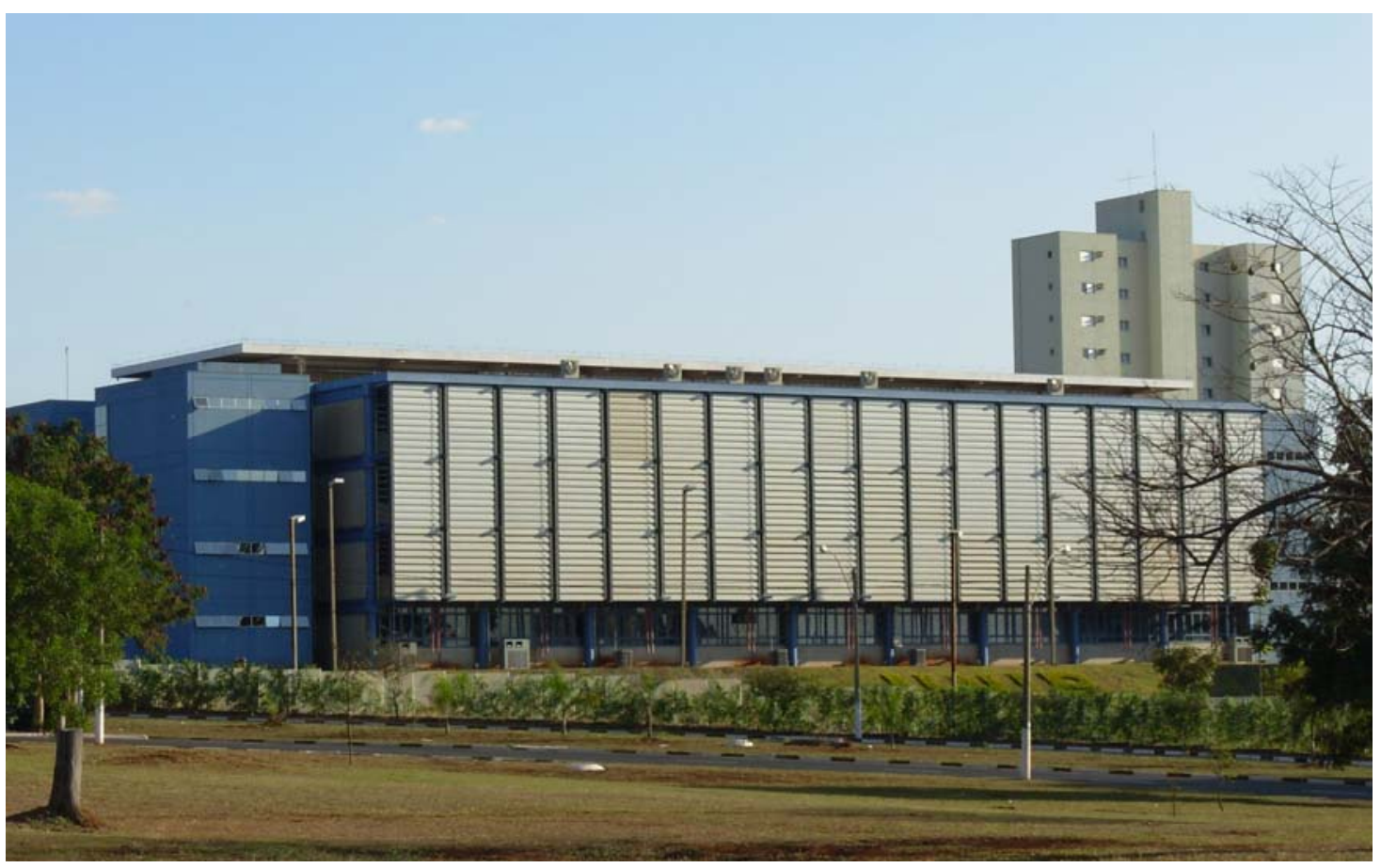

Figura 5. 11 Fachada Nordeste Edifício 1 da UNIP. (Autora)

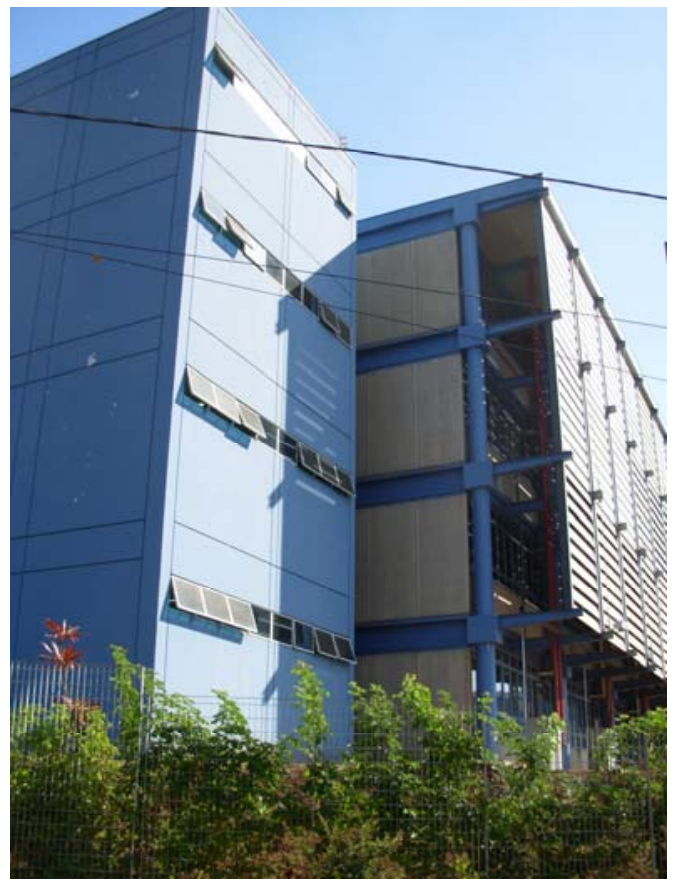

Figura 5. 12 Detalhe dos brises. (Autora)

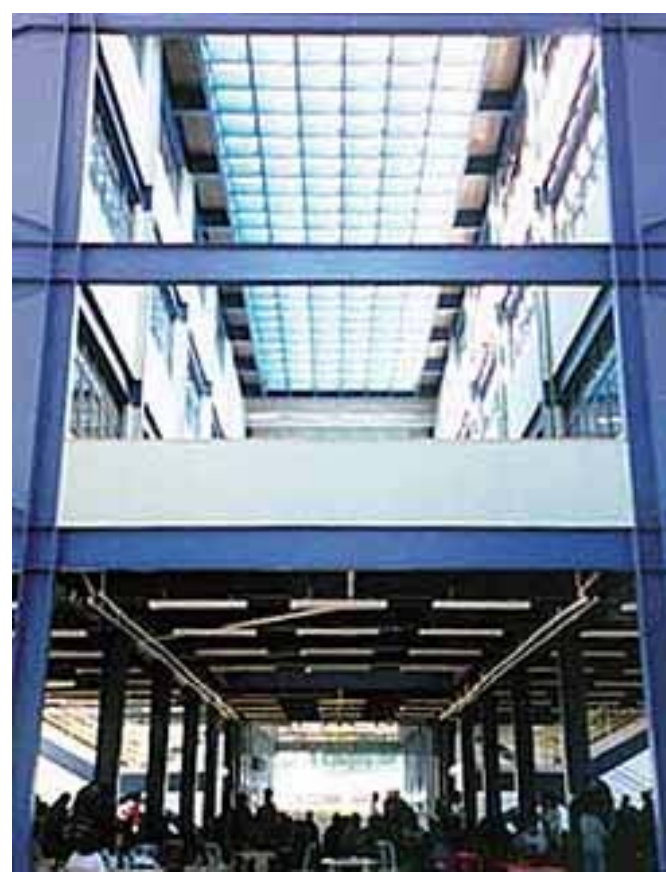

Figura 5. 13 Vazio interno ventilado. (Autora)

O edifício é composto por dois corpos de salas de aula separados por um vazio interno com passarelas de ligação. Este grande vazio (figura 5.13) possui as 
extremidades abertas, o que permite uma boa ventilação natural nas áreas de convivência.

\subsubsection{Edifício New Century}

O edifício de escritórios New Century, projeto do arquiteto Carlos Troca, está localizado na Avenida Presidente Vargas, principal corredor comercial da Zona Sul. Neste projeto foi adotada a tipologia de fechamento em "pele de vidro", com vidros refletivos na cor azul. A tipologia construtiva e a orientação adotada colocam os escritórios dispostos nas fachadas noroeste e sudoeste totalmente expostos à radiação solar direta no período da tarde. A foto tirada no mês de julho às 15h30minh (figura 5.14) mostra o sol refletido na fachada noroeste.

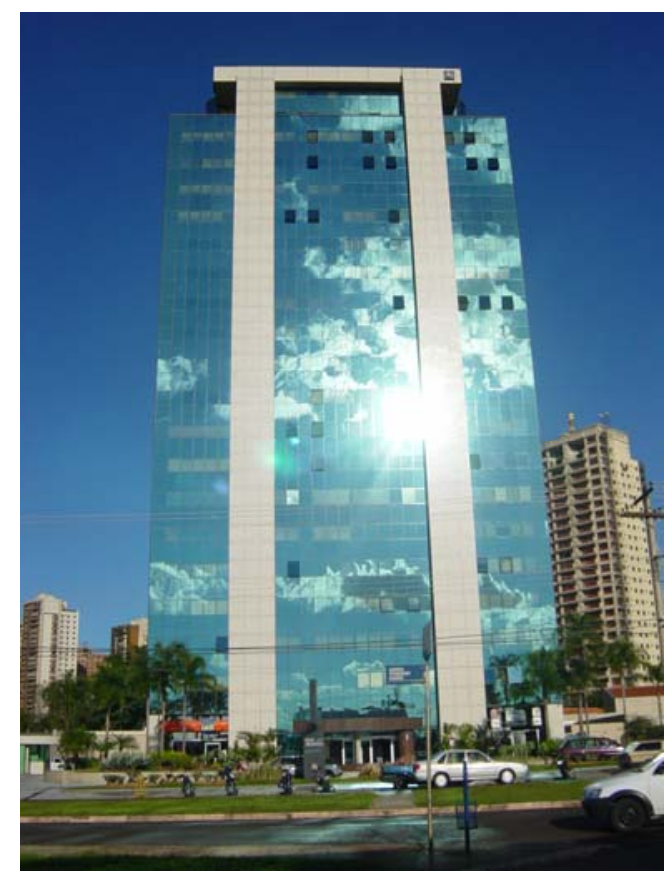

Figura 5. 14 Fachada Noroeste. (Autora)

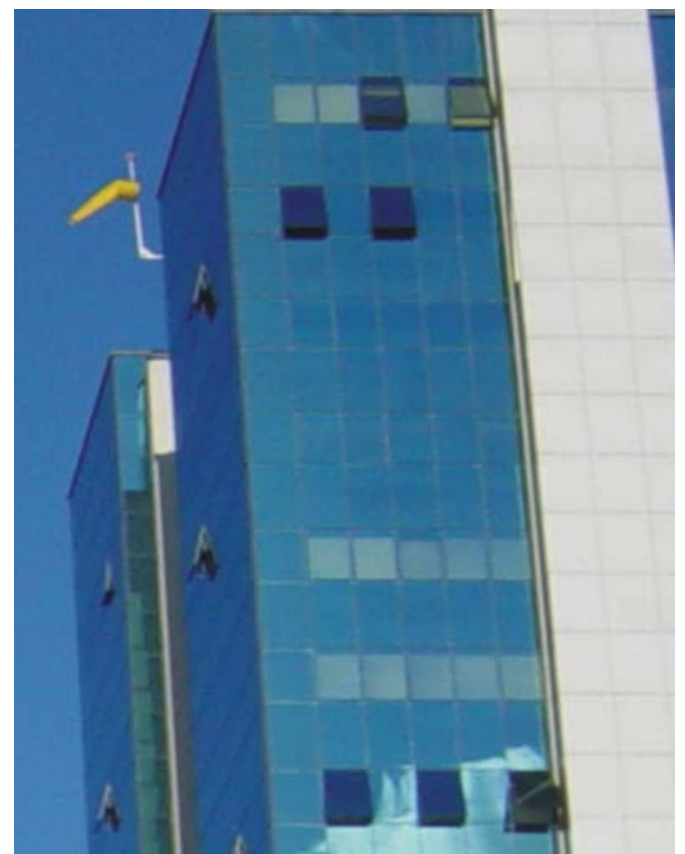

Figura 5. 15 Detalhe das aberturas. (Autora)

De acordo o fornecedor, vidro refletivo azul foi utilizado por barrar o calor. Um dos proprietários de escritório no edifício, que permitiu uma visita interna, afirma que a necessidade de utilização de ar condicionado assim como a potencia das máquinas 
nas unidades destas fachadas é muito maior. A possibilidade de ventilação natural nos escritórios resume-se a poucas aberturas do tipo máximo-ar (figura 5.15).

\subsubsection{Sede Casa Cor Interior 2006}

Projeto do escritório ribeirãopretano C4 Arquitetos Associados, a residência sede da casa interior 2006 está localizada num condomínio fechado em Araraquara, onde posteriormente ao evento foi disponibilizada para comercialização. Os arquitetos previram um grande volume de vidro na fachada com pé direito duplo, onde estavam dispostas áreas sociais da casa. Em visita ao local na ocasião do evento, detectouse a penetração do sol nestes ambientes no período da tarde, como se vê na figura 5.16 .

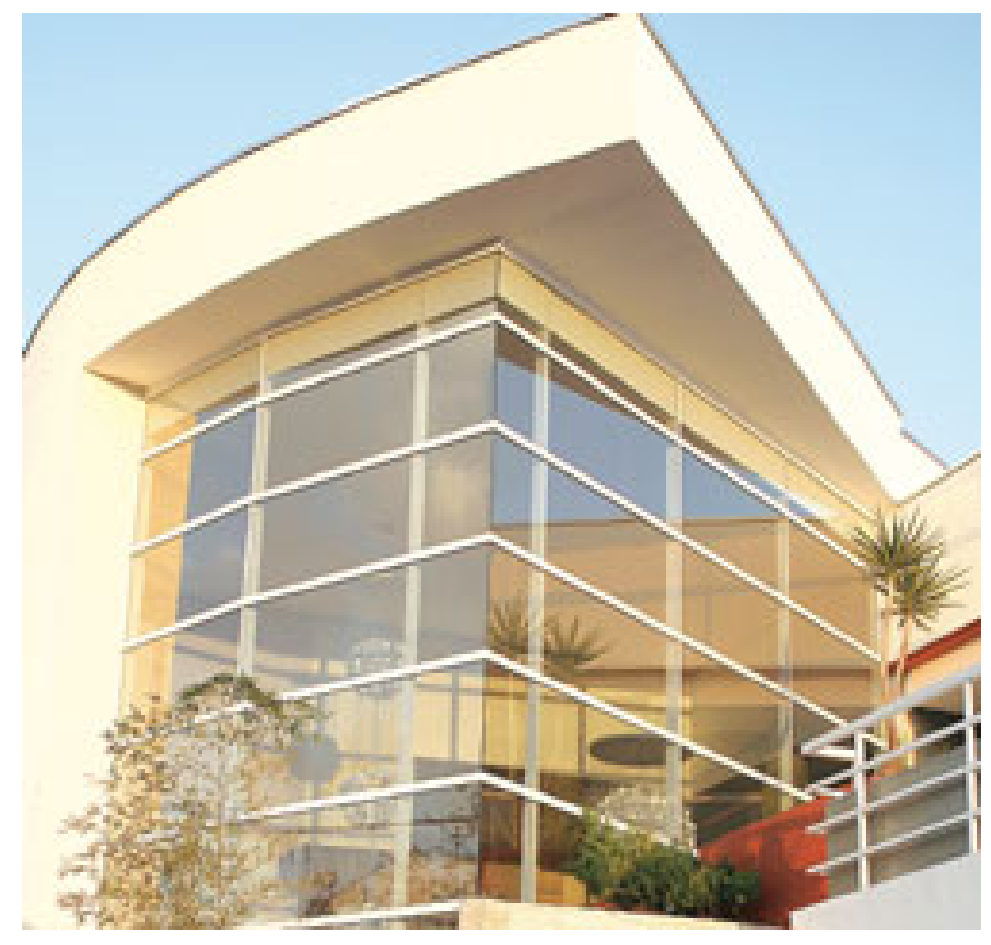

Figura 5. 16 Fachada da Casa Cor Interior 2006 (A CIDADE, 2006).

Em entrevista ao jornal A Cidade (23/07/2006), os arquitetos comentam: 
Para permitir a visualização dos espaços externos e garantir a privacidade dos ambientes, o vidro recebeu uma película. O conforto térmico e iluminação natural foram garantidos. O vidro funciona como uma estufa. A película permite a entrada da claridade sem o ganho de calor. Serve como isolante térmico.

Segundo o arquiteto, além do tratamento de bloqueio de raios ultravioletas e de calor, a película possibilita um ganho de produtividade do ambiente. Ela agrega ao vidro valores como conforto, privacidade e decoração. A entrevista também conta com o depoimento do de Luciano Arruda, gerente regional da Solutia, empresa fabricante de películas para vidros: "Nas películas de controle solar há rejeição de energia solar em até $79 \%$ e o bloqueio de raios ultravioletas pode chegar a 99,9\%". Apesar da informação acima, segundo CARAM (1999), a maioria das películas existentes no mercado barram uma pequena parcela dos raios infra-vermelhos em relação aos outros comprimentos de onda, mas dentro do espectro solar, são estes os responsáveis pela sensação de calor.

\subsubsection{Residência Royal Park}

Nesta residência, localizada em um condomínio na zona sul da cidade, o arquiteto Pedro, baseado em sua experiência profissional, utilizou duas estratégias para minimizar a incidência de radiação solar pelas superfícies. 


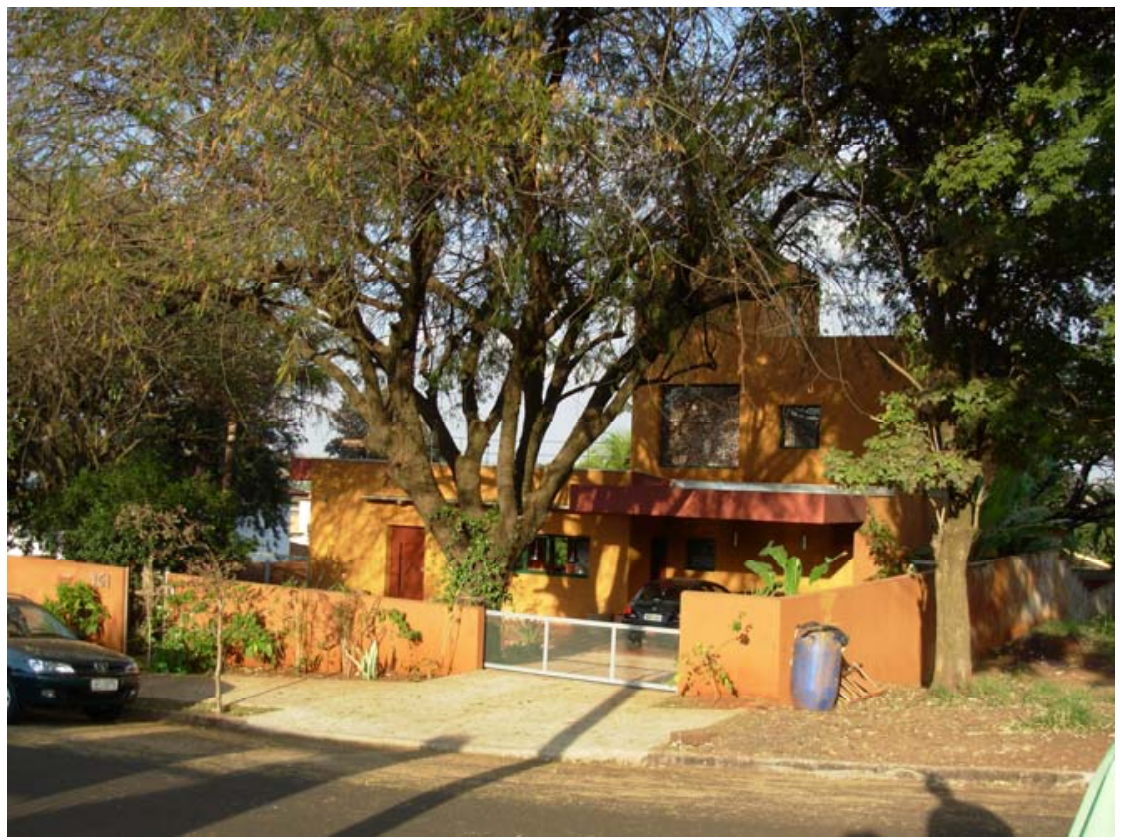

Figura 5. 17 Fachada residência Royal Park. (Autora)

A primeira foi tomar partido das arvores existentes no terreno para a implantação da edificação. Aumentando o recuo frontal, a fachada recebe sombreamento das arvores no período da tarde (figura 5.17).

A segunda estratégia foi a utilização de uma cobertura verde, constituída por laje impermeabilizada, terra e grama. Este tipo de cobertura apresenta ótimo desempenho em climas quentes devido à proteção contra a radiação direta, o amortecimento da amplitude térmica das temperaturas superficiais da cobertura e a redução da temperatura superficial interna em relação a outros tipos de cobertura (VECCHIA, 2005). Porém, no caso desta residência, os sistemas de impermeabilização e drenagem indicados pelas pesquisas existentes em coberturas verdes não foram executados. Após seis meses de conclusão da obra, a cobertura apresentou diversos pontos de infiltração, o que levou os proprietários a remover a terra e grama para reparos na impermeabilização e manter a cobertura somente como laje impermeabilizada. 


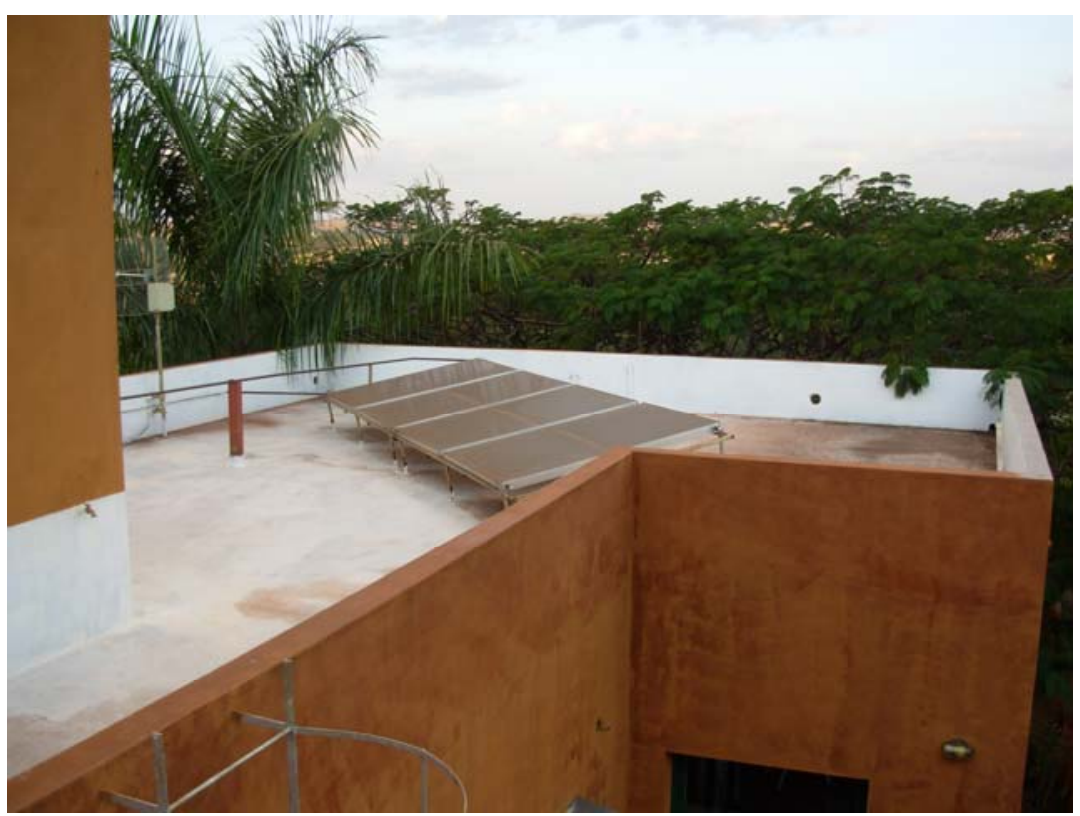

Figura 5. 18 Detalhe da cobertura residência Royal Park. (Autora)

Os proprietários afirmam ter sentido aumento na temperatura interna após a retirada da vegetação, mas mesmo assim preferiram não mais utilizá-la para evitar a ocorrência de novas infiltrações. Outra questão apontada é a importância de se prever um sistema de irrigação da cobertura verde, que facilite a manutenção da vegetação principalmente durante o longo período de chuvas escassas na cidade.

\subsubsection{Considerações}

Vê-se em algumas edificações a adoção de materiais e tipologias prejudiciais ao conforto térmico em função de questões estéticas e do status do edifício. Em alguns casos percebe-se que há a preocupação com o conforto térmico por parte do profissional, que buscam utilizar estratégias de condicionamento passivo. Porém, na maioria das vezes as estratégias são utilizadas com base na intuição do profissional ou em informações de catálogos de fabricantes de materiais, como o caso das películas. 
Assim como em outros locais, em Ribeirão Preto há uma lacuna entre a prática do projeto de edificações e as pesquisas em conforto térmico. Ainda que haja a preocupação com o conforto térmico por parte dos profissionais, muitas vezes estes se deparam com limitações, como já visto no capítulo 4. Mais uma vez destaca-se a necessidade de uma ferramenta de projeto que aproxime o profissional projetista do ambiente de pesquisa e forneça subsídios para a incorporação das questões de conforto de maneira correta em seus projetos.

\subsection{MATERIAIS E SISTEMAS CONSTRUTIVOS}

As edificações em Ribeirão Preto, em sua grande maioria, apresentam os seguintes materiais construtivos para as vedações externas: paredes em tijolo cerâmico furado rebocado de ambos os lados, forro em laje mista e cobertura em telha cerâmica com estrutura de madeira. A utilização destes materiais está relacionada mais à questões econômicas do que a questões de conforto térmico. Quando há maior preocupação com o conforto térmico, frequentemente os profissionais optam pela utilização do tijolo cerâmico maciço por acreditarem ser uma melhor opção frente ao tijolo furado.

Primeiramente é preciso ressaltar que as condições de conforto térmico de um ambiente dependem de vários fatores, sendo a composição do material de vedação apenas um deles. Assim, a simples definição de um material pode ser insuficiente para resolver as questões de conforto térmico. Além disto, diferenças de valores numéricos nas propriedades térmicas dos materiais podem não se refletir significativamente na temperatura de um ambiente.

Deve-se também observar a relevância de cada vedação externa em relação ao tipo de edificação. Em geral, a cobertura é o componente de maior absorção de calor em edificações térreas, enquanto nos edifícios altos sãos as vedações verticais as maiores responsáveis pela absorção de calor. Em relação às paredes, a utilização de materiais adequados ao clima quente pode ter seu desempenho térmico comprometido pela orientação inadequada desta ou pela presença de grandes áreas 
envidraçadas. Assim, no caso de Ribeirão Preto, fatores como orientação favorável e proteções solares podem ter maior influência nas temperaturas internas dos ambientes que os materiais das vedações.

Os sistemas de cobertura geralmente estão em posição próxima ao plano horizontal, e por isso recebe incidência da radiação direta durante quase todo o período diurno. Em um clima quente como o de Ribeirão Preto, isso significa um enorme ganho de calor por esta superfície, que consequentemente contribuirá para o aquecimento excessivo dos ambientes internos. Para minimizar este aquecimento, fatores como a cor da superfície da cobertura e a presença de ático (vão entre telhado e forro) podem ser mais eficientes que o material de cobertura.

Em ensaios e medições feitos por Peralta (2007), foi concluído que coberturas com telha metálica e de fibrocimento tiveram desempenho térmico muito superior quando receberam pintura na cor branca. Assim, pode-se considerar a utilização destes materiais de cobertura em Ribeirão, desde que tratados com a cor adequada em sua superfície externa.

Outro recurso para atenuar a absorção de calor pela cobertura durante o dia e resfriá-la mais rapidamente durante a noite é a utilização do ático ventilado (DUARTE, 1997). A circulação de ar no espaço entre forro e cobertura ajuda a reduzir o fluxo de calor descendente (da cobertura para o ambiente interno) que ocorre durante o dia. Já durante a noite, a ventilação acelera o fluxo de calor ascendente ( $\mathrm{d}$ o ambiente interno para a cobertura), auxiliando na retirada de calor do ambiente interno.

De acordo com pesquisas recentes, um sistema de cobertura que tem se mostrado favorável ao conforto térmico em climas quentes é a cobertura verde (MORAIS; RORIZ, 2005). A presença de vegetação na cobertura resulta no grande atraso da ocorrência dos picos de temperatura superficial assim como na redução desta, contribuindo para um menor aquecimento dos ambientes internos (VECCHIA, 2005). Cabe ressaltar que, para o bom funcionamento do sistema, deve-se executá-lo de acordo com as especificações do método construtivo contidas nas pesquisas existentes. 


\section{METODOLOGIA}

Para gerar um conjunto de recomendações de projeto visando o conforto térmico em edificações para a cidade de Ribeirão Preto, foram utilizadas duas ferramentas amplamente conhecidas e utilizadas: a norma da ABNT NBR 15220 e o Método de Mahoney. As ferramentas foram aplicadas separadamente sendo que para o Método de Mahoney foram utilizados os dados climáticos obtidos na estação meteorológica do IAC.

Sabe-se que ambas as ferramentas tecem recomendações com base em climas quente-seco e quente-umido. O clima de Ribeirão Preto apresenta ao longo do ano um período quente-seco e um período quente-umido, ambos de maneira relevante, o que é considerado por alguns autores como clima composto. Portanto, algumas recomendações obtidas podem ser inadequadas ou insufucientes para atender às necessidades de conforto das edificações na cidade. Assim, foram analisados os dados climáticos de temperatura, umidade, chuvas, ventos e radiação global ao longo do ano e também as condições fisiográficas da área do município. As conclusões desta análise climática foram discutidas e confrontadas através de tabela comparativa, com as recomendações obtidas da aplicação das duas ferramentas.

Esta confrontação permitirá:

- complementar as recomendações obtidas com a aplicação das ferramentas

- ponderar a relevância de cada recomendação para o clima local

- auxiliar na decisão e escolha entre possíveis recomendações conflitantes

- auxiliar na formação de um conjunto único de recomendações específicas para o clima de Ribeirão Preto.

Devido ao clima quente, a radiação solar figura como o principal fator de desconforto térmico em edificações na cidade. A partir da carta solar para a latitude de $21^{\circ} 10^{\prime} \mathrm{S}$, fez-se o traçado dos ângulos de incidência solar de oito orientações diferentes para os meses de setembro, dezembro e março, que compreendem o período mais 
quente do ano na cidade. Este traçado permite observar a trajetória solar na cidade assim como sua incidência em fachadas, facilitando a previsão e projeto de proteções solares para aberturas e superfícies expostas à radiação solar. 


\section{RESULTADOS}

\subsection{PARTICULARIDADES DO CLIMA EM RIBEIRÃO PRETO}

Há o consenso entre os autores pesquisados que os principais aspectos climáticos que agem diretamente sobre a edificação e, portanto, no conforto ambiental da mesma são: Temperatura do ar (bulbo-seco), Umidade relativa do ar, Ventos, Radiação Solar e Precipitações. Porém, alguns destes fatores podem ter maior ou menor relevância no conforto térmico de acordo com as características climáticas locais. A seguir, são apresentados os dados climáticos de Ribeirão Preto de acordo com a estação meteorológica do IAC, destacando o comportamento destes e sua relevância para o clima local.

\subsubsection{Temperatura do Ar}

Tabela 7.1 - Dados de temperatura de Ribeirão Preto (Estação Meteorológica do IAC).

\begin{tabular}{|l|l|l|l|l|l|l|l|l|l|l|l|l|}
\hline & JAN & FEV & MAR & ABR & MAIO & JUN & JUL & AGO & SET & OUT & NOV & DEZ \\
\hline MAX ABS $^{\circ} \mathbf{C}$ & 33,5 & 33,5 & 33,4 & 32,0 & 30,4 & 29,7 & 30,4 & 33,6 & 35,2 & 35,3 & 34,5 & 33,7 \\
\hline MED MAX $^{\circ} \mathbf{C}$ & 29,9 & 30,3 & 30,2 & 29,1 & 27,0 & 26,1 & 26,7 & 29,0 & 30,3 & 30,4 & 30,1 & 29,5 \\
\hline MIN ABS $^{\circ} \mathbf{C}$ & 15,8 & 16,1 & 14,7 & 11,8 & 8,1 & 5,8 & 5,8 & 7,3 & 10,0 & 12,3 & 13,3 & 14,8 \\
\hline MED MIN $^{\circ} \mathbf{C}$ & 18,7 & 18,6 & 17,9 & 16,1 & 13,5 & 12,1 & 11,9 & 13,5 & 15,6 & 17,0 & 17,6 & 18,4 \\
\hline MEDIAS $^{\circ} \mathbf{C}$ & 24,3 & 24,4 & 24,0 & 22,6 & 20,3 & 19,1 & 19,3 & 21,2 & 22,9 & 23,7 & 23,9 & 24,0 \\
\hline
\end{tabular}

O período quente tem grande representatividade no ano, sendo que durante nove meses, de agosto a abril, a temperatura média das máximas está acima de $29^{\circ} \mathrm{C}$. Os meses de outubro e setembro apresentam as maiores medis das máximas $\left(30,4^{\circ} \mathrm{C}\right.$ e $30,3^{\circ} \mathrm{C}$ respectivamente) e também as maiores máximas absolutas $\left(35,3^{\circ} \mathrm{C}\right.$ e $35,2^{\circ} \mathrm{C}$ 
respectivamente). $\mathrm{O}$ fato de os meses de dezembro e janeiro apresentarem temperaturas menores deve-se à maior ocorrência de chuvas, que contribui para um menor aquecimento. O período frio, de maio a julho, tem pouca representatividade no ano. Mesmo nestes meses as médias das máximas ficam entre $26^{\circ} \mathrm{C}$ e $27^{\circ} \mathrm{C}$, o que leva a considerar os período diurno como confortável, e não como frio.

\subsubsection{Umidade Relativa}

Tabela 7.2 - Dados de umidade relativa de Ribeirão Preto (Estação Meteorológica do IAC).

\begin{tabular}{|l|l|l|l|l|l|l|l|l|l|l|l|l|}
\hline & JAN & FEV & MAR & ABR & MAIO & JUN & JUL & AGO & SET & OUT & NOV & DEZ \\
\hline UMID REL $\%$ & 80,5 & 81,1 & 80,2 & 73,2 & 74,4 & 70,5 & 64,9 & 57,1 & 62,2 & 68,4 & 73,6 & 80,3 \\
\hline
\end{tabular}

A umidade relativa média varia entre $81,1 \%$ e $57,1 \%$ ao longo do ano. Os meses mais úmidos são de dezembro a março, quando a umidade é maior que $80 \%$.Os meses mais secos são de julho a outubro, quando a umidade fica abaixo de $70 \%$. Destaca-se aqui a ocorrência de um período quente e úmido, de dezembro a março, com temperaturas e umidades relativas altas, e um período quente e seco, de agosto a outubro, com temperaturas altas e umidades baixas. Cabe ressaltar que valores médios de umidade podem não mostrar ocorrências específicas locais. No caso de Ribeirão Preto, a umidade relativa varia consideravelmente durante um dia, apresentando valores mais baixos no período da tarde. Durante os meses mais secos a umidade relativa frequentemente atinge valores críticos abaixo de $20 \%$, o que pode ser comprovado através da observação dos dados diários da Estação Meteorológica da UNAERP.

\subsubsection{Precipitação}


Tabela 7.3 - Dados de pluviosidade de Ribeirão Preto (Estação Meteorológica do IAC).

\begin{tabular}{|l|l|l|l|l|l|l|l|l|l|l|l|l|}
\hline & JAN & FEV & MAR & ABR & MAIO & JUN & JUL & AGO & SET & OUT & NOV & DEZ \\
\hline $\begin{array}{l}\text { CHUVAS } \\
\mathbf{m m}\end{array}$ & 260,2 & 217,7 & 163,4 & 82,8 & 60,4 & 31,8 & 24,4 & 25,7 & 57,1 & 136,9 & 173,1 & 285,9 \\
\hline
\end{tabular}

A média de precipitação no ano é de $1519,4 \mathrm{~mm}$. O ano pode ser dividido em seis meses chuvosos, com precipitação acima de $137 \mathrm{~mm}$, e seis meses de seca, com precipitação abaixo de $83 \mathrm{~mm}$. Porém, nos meses de dezembro, janeiro e fevereiro ocorre mais de $50 \%$ das chuvas, revelando uma má distribuição destas ao longo do ano.

\subsubsection{Ventos e condições de ventilação natural}

Tabela 7.4 - Dados de vento de Ribeirão Preto (Estação Meteorológica do IAC).

\begin{tabular}{|l|l|l|l|l|l|l|l|l|l|l|l|l|}
\hline & JAN & FEV & MAR & ABR & MAIO & JUN & JUL & AGO & SET & OUT & NOV & DEZ \\
\hline VEL $\mathbf{m} / \mathbf{s}$ & 1,6 & 1,4 & 1,3 & 1,5 & 1,4 & 1,4 & 1,8 & 2,0 & 2,3 & 2,3 & 2,2 & 1,9 \\
\hline DIR. & NW & SE & SE & SE & SE & SE & SE & SE & SE & SE & SE & SE \\
\hline
\end{tabular}

A predominância dos ventos é de sudeste durante onze meses do ano. Os meses de setembro, outubro e novembro apresentam maiores velocidades médias, sendo este o período quente e seco . Cabe ressaltar que as medidas apresentadas são aferidas a 10 metros de altura do solo e em área descampada, devendo-se considerar que em zonas adensadas certamente ocorre redução destas velocidades.

\subsection{ANÁLISE DA INCIDÊNCIA DE RADIAÇÃO SOLAR}

Para estimar os impactos da radiação solar sobre determinada superfície, é necessário conhecer a quantidade de radiação recebida em watts por metro 
quadrado $\left(\mathrm{W} / \mathrm{m}^{2}\right)$. Este valor depende dos ângulos de incidência do sol sobre esta superfície, que por sua vez, estão relacionados à altura solar a ao azimute. Tais dados podem ser obtidos a partir da leitura da carta solar do local em questão. Utilizando o software 'Introdução às Cartas Solares' (BITENCOURT, 2004), gerou-se a carta solar para a latitude de Ribeirão Preto (figura 7.1).

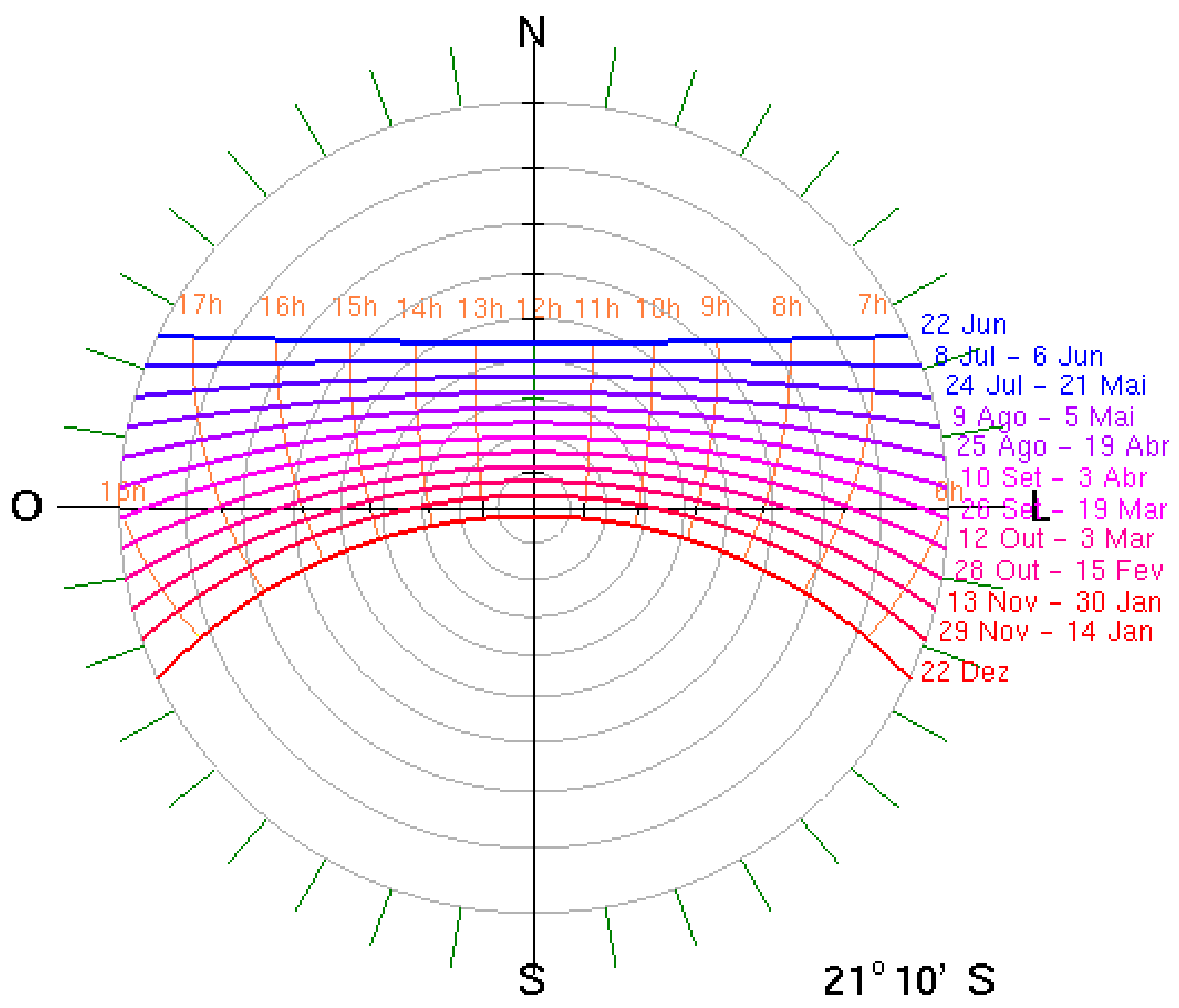

Figura 7. 1 Carta Solar para latitude $21^{\circ} 10^{\prime} \mathrm{S}$. (BITENCOURT, 2004).

A partir desta carta, fez-se o traçado dos ângulos de incidência e a quantificação do tempo de incidência para oito fachadas com orientações distintas: Norte, Nordeste, Leste, Sudeste, Sul, Sudoeste, Oeste e Noroeste. Foram considerados os meses de Setembro, Dezembro e Março, que correspondem ao período mais quente, quando a radiação direta é mais prejudicial ao conforto térmico no caso de Ribeirão Preto. 


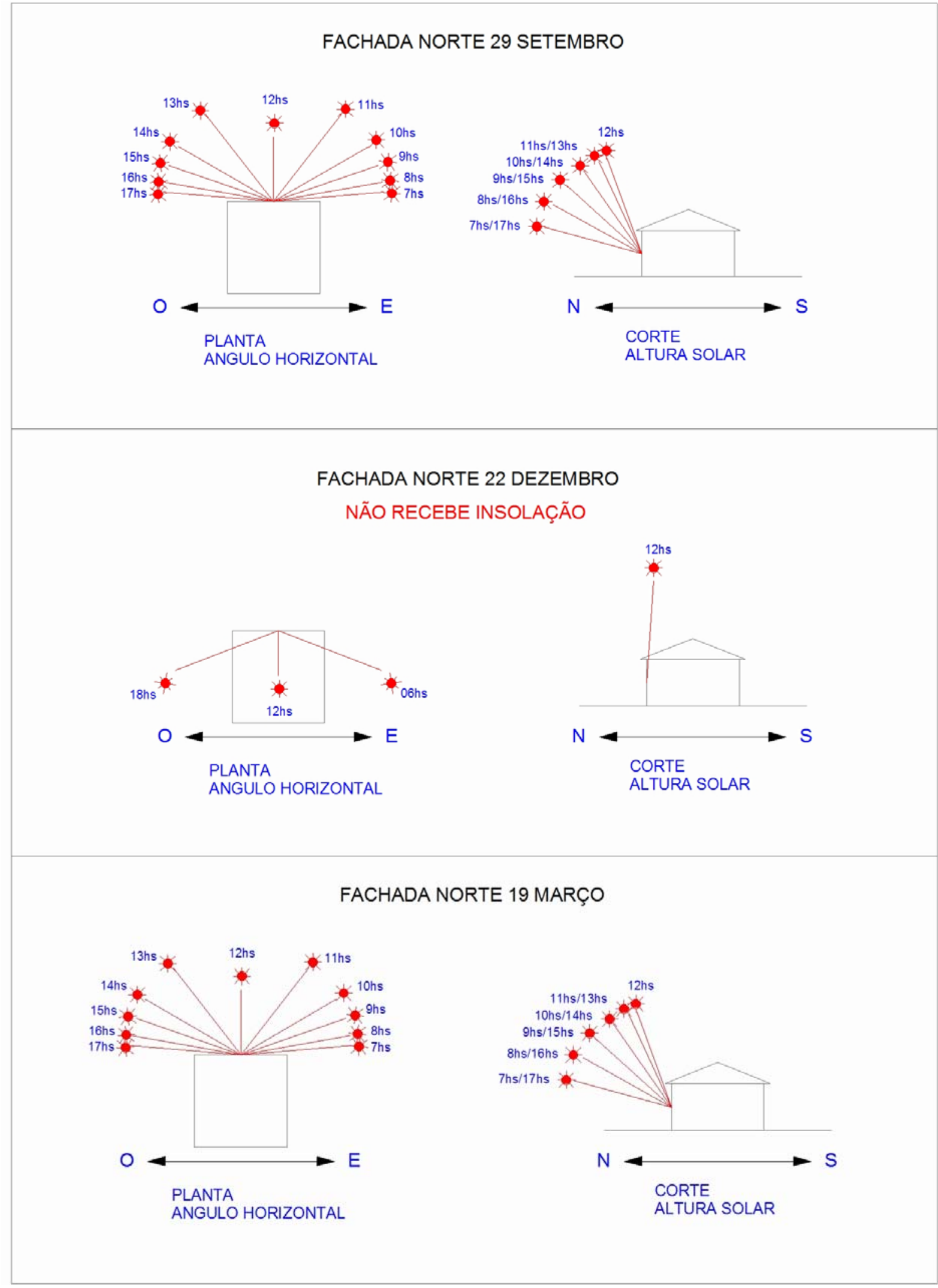

Figura 7. 2 - Ângulos de incidência solar na fachada Norte. 
FACHADA NORDESTE 29 SETEMBRO
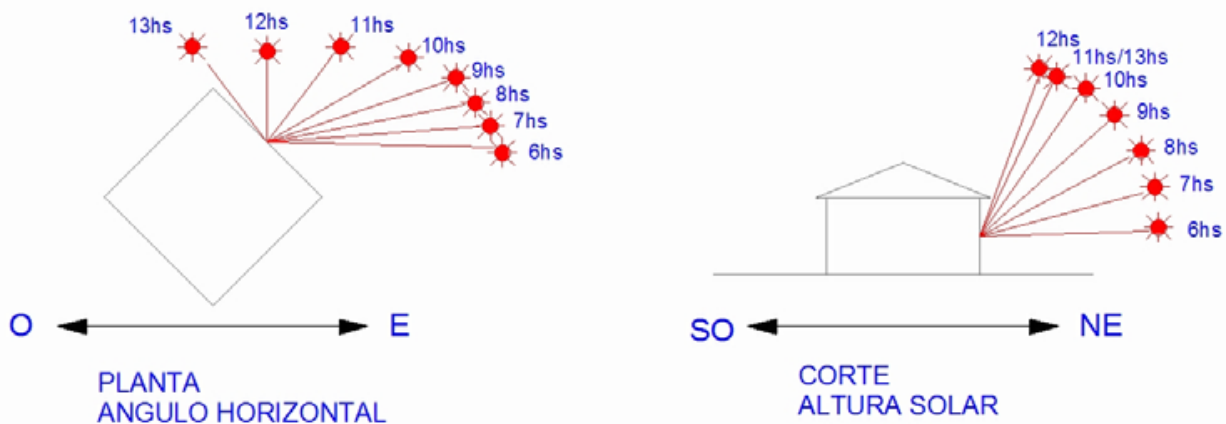

FACHADA NORDESTE 22 DEZEMBRO
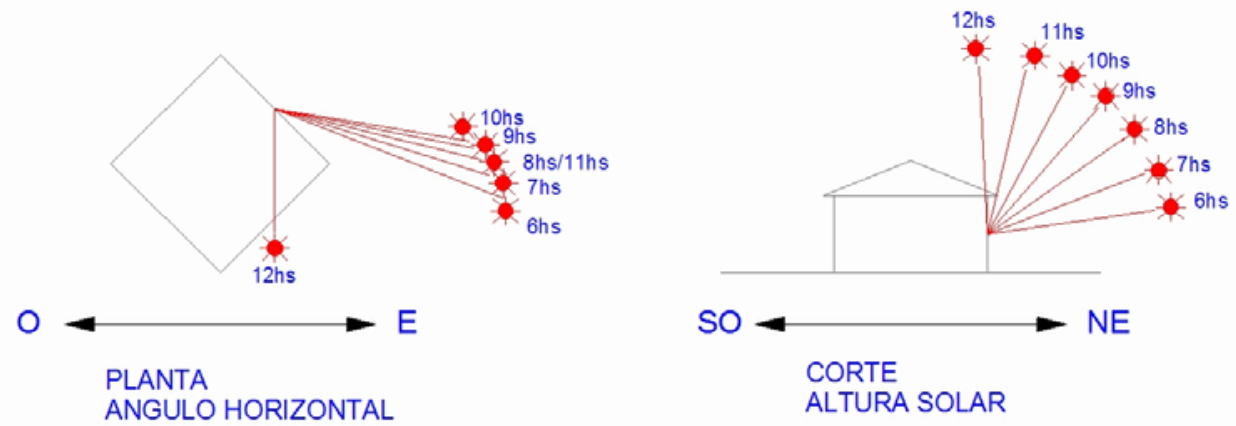

ANGULO HORIZONTAL

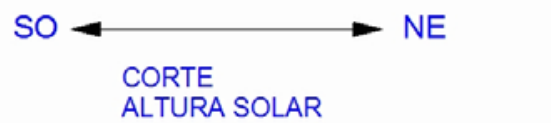

FACHADA NORDESTE 19 MARÇO
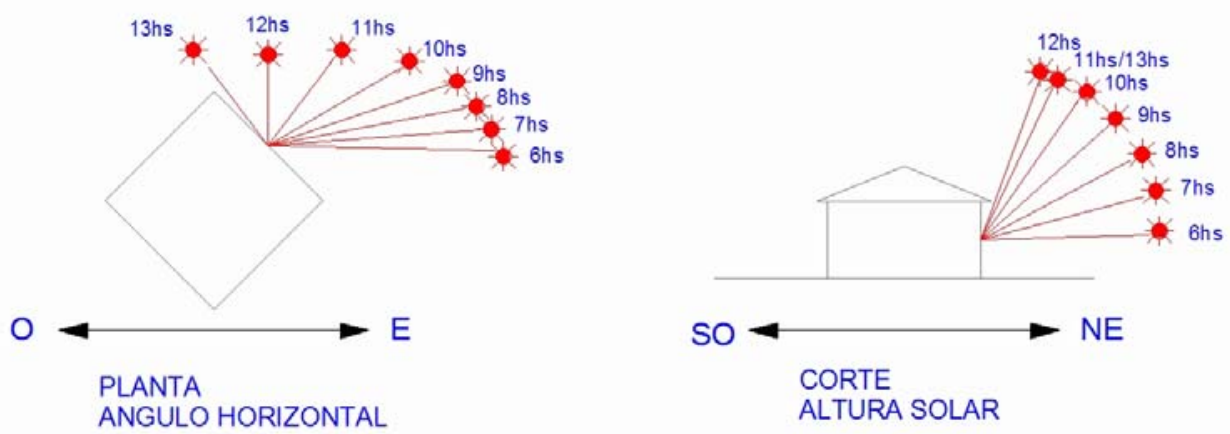

Figura 7. 3 - Ângulos de incidência solar na fachada Nordeste 
FACHADA LESTE 29 SETEMBRO
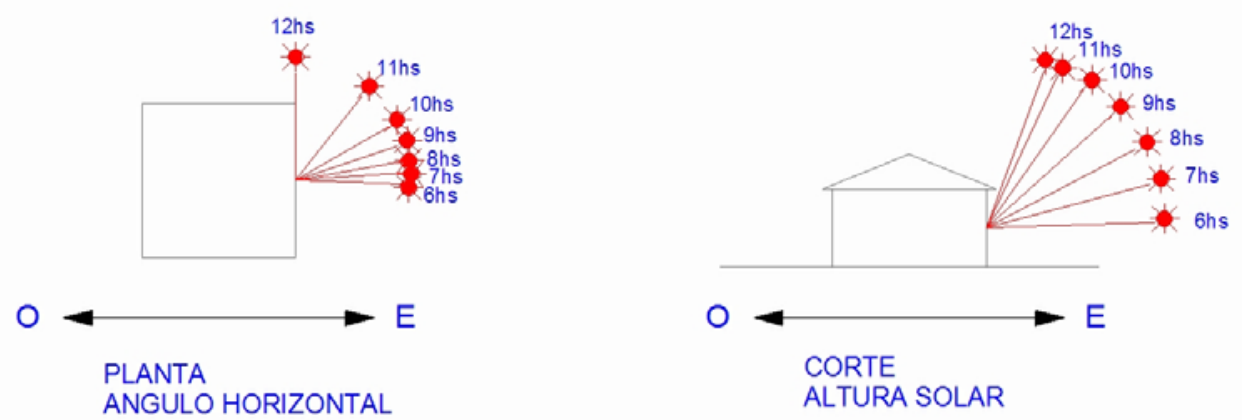

FACHADA LESTE 22 DEZEMBRO
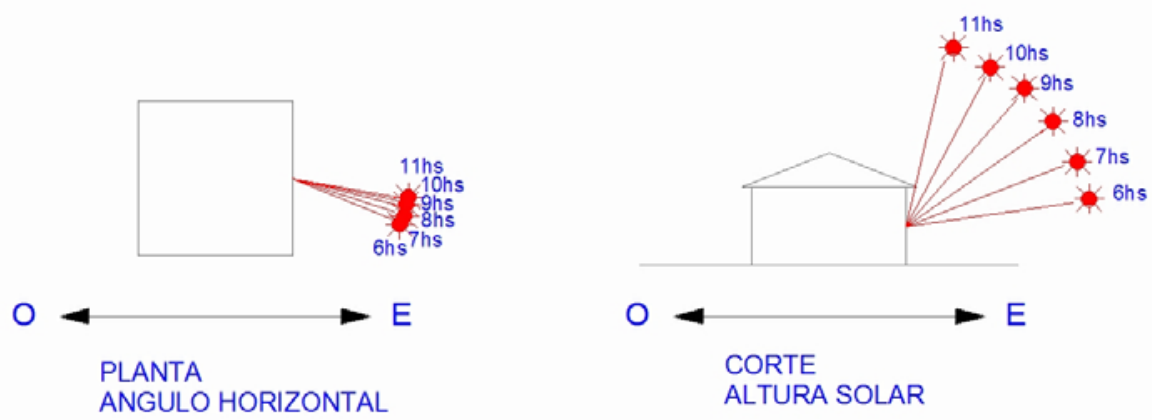

PLANTA

ANGULO HORIZONTAL

○

CORTE

ALTURA SOLAR

FACHADA LESTE 19 MARÇO
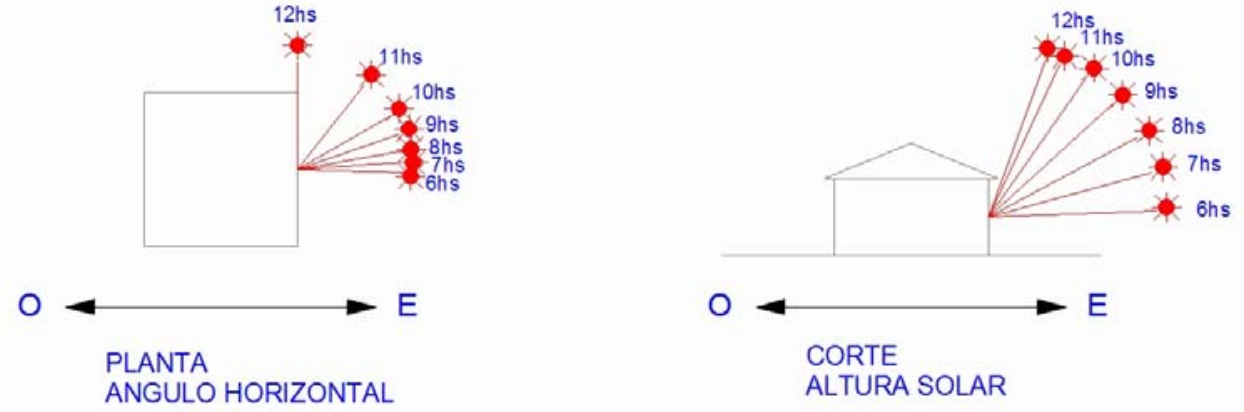

Figura 7. 4 - Ângulos de incidência solar na fachada Leste. 


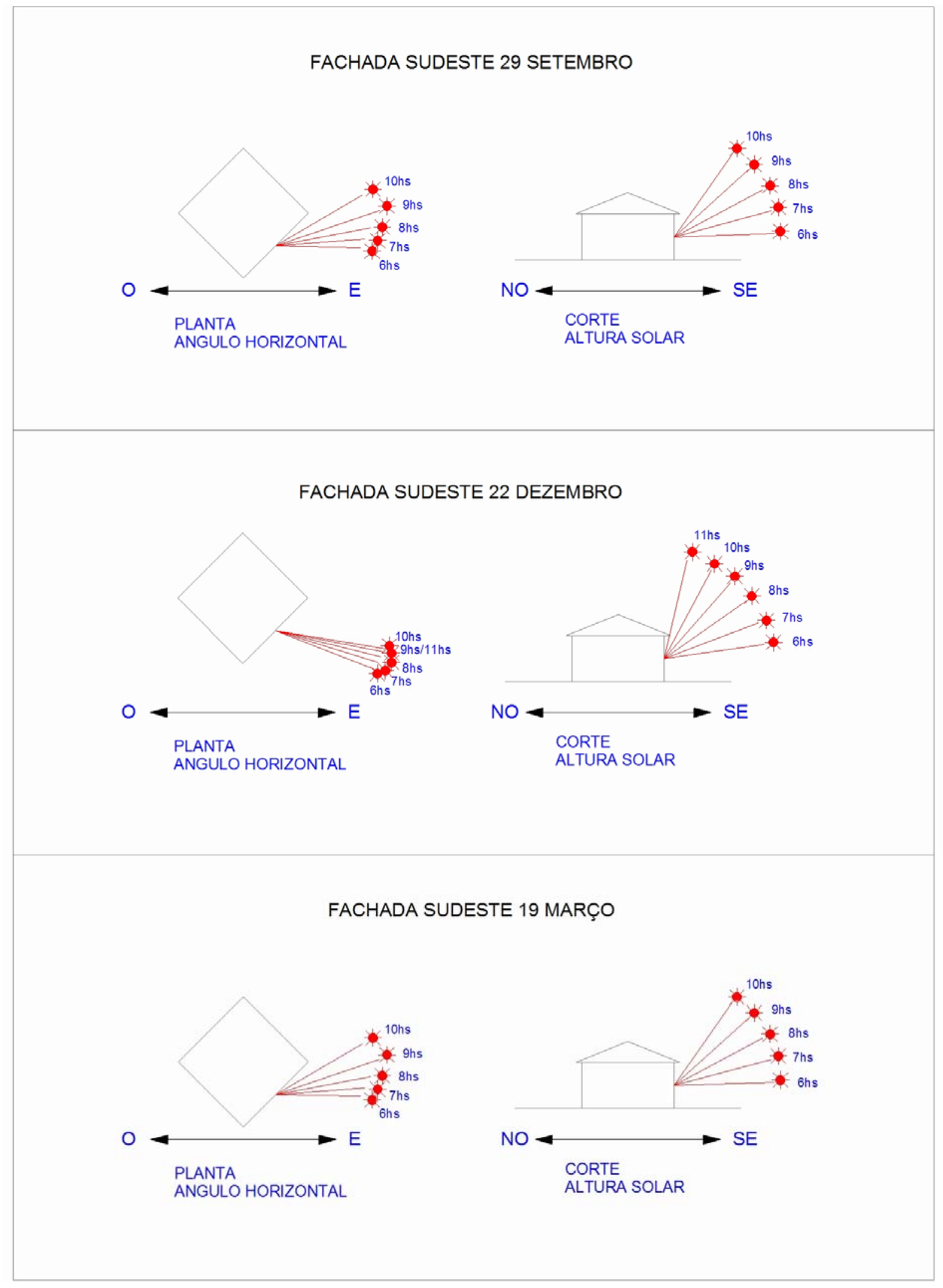

Figura 7. 5 - Ângulos de incidência solar na fachada Sudeste. 
FACHADA SUL 29 SETEMBRO
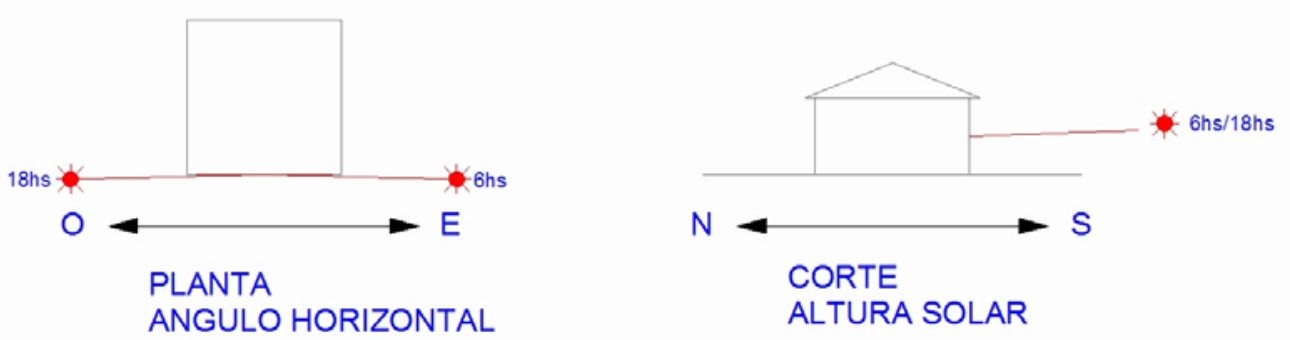

FACHADA SUL 22 DEZEMBRO
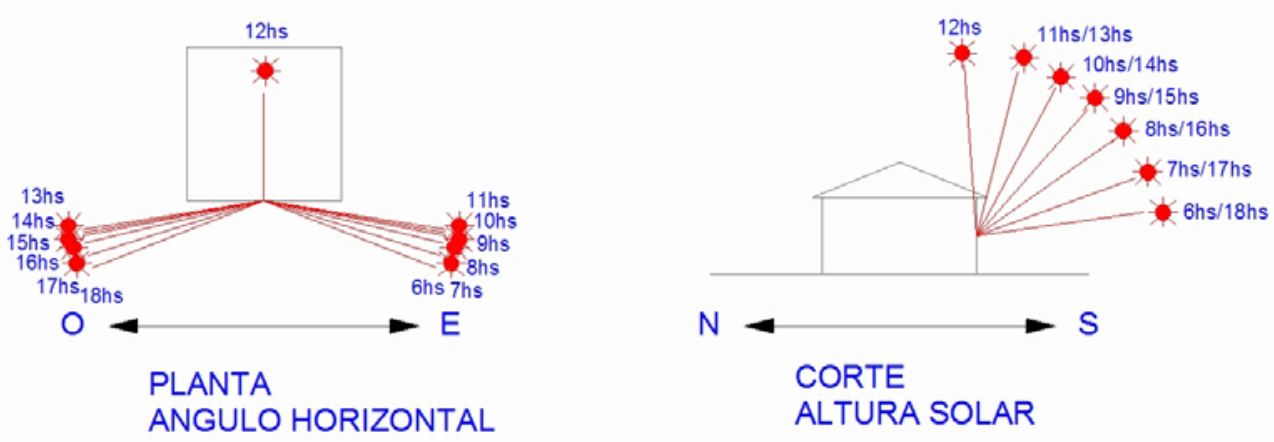

FACHADA SUL 19 MARÇO
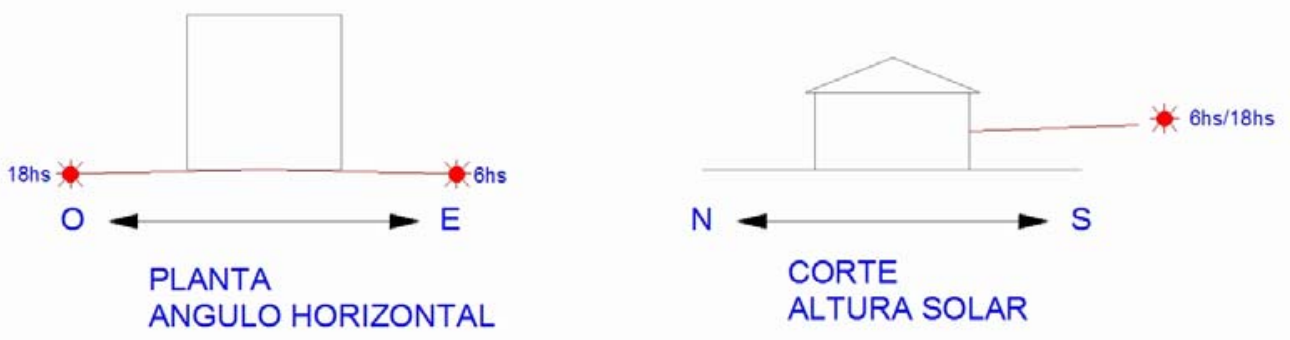

Figura 7. 6 - Ângulos de incidência solar na fachada Sul. 
FACHADA SUDOESTE 29 SETEMBRO
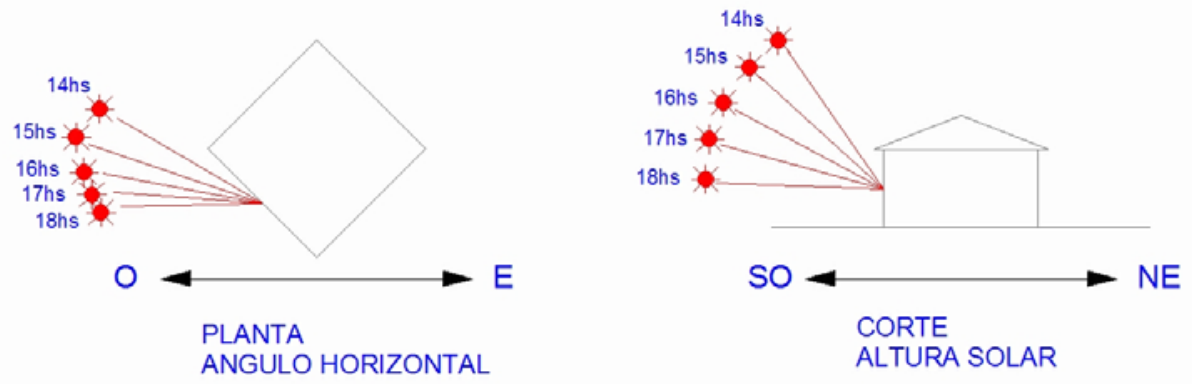

FACHADA SUDOESTE 22 DEZEMBRO
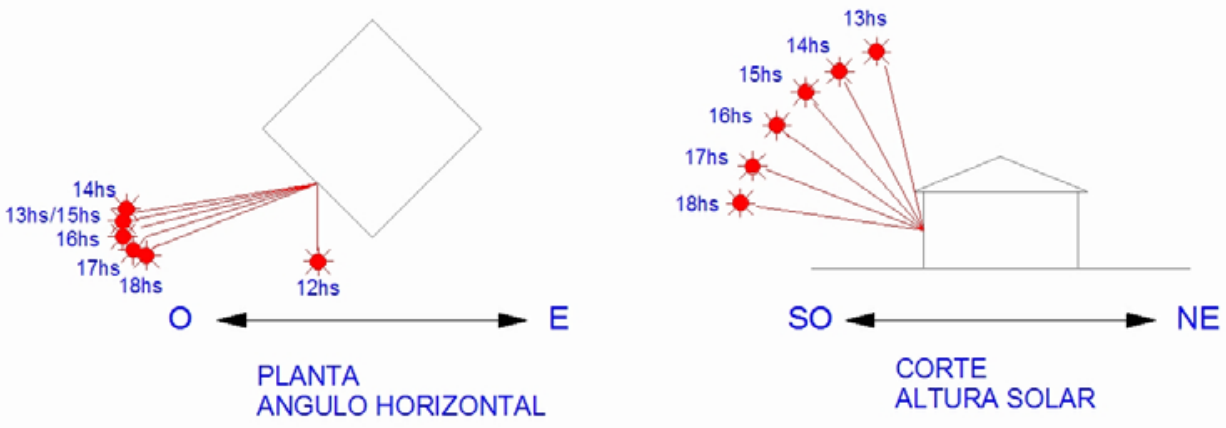

FACHADA SUDOESTE 19 MARÇO
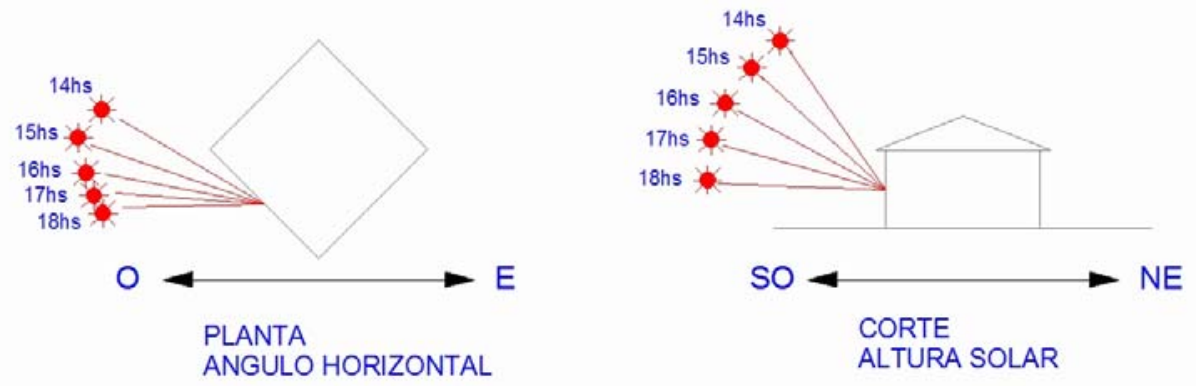

Figura 7. 7 - Ângulos de incidência solar na fachada Sudeste. 
FACHADA OESTE 29 SETEMBRO
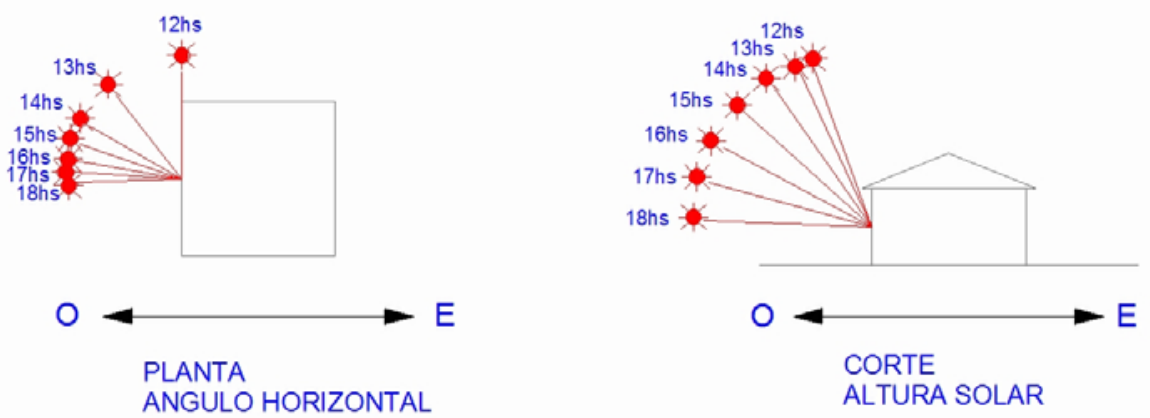

FACHADA OESTE 22 DEZEMBRO
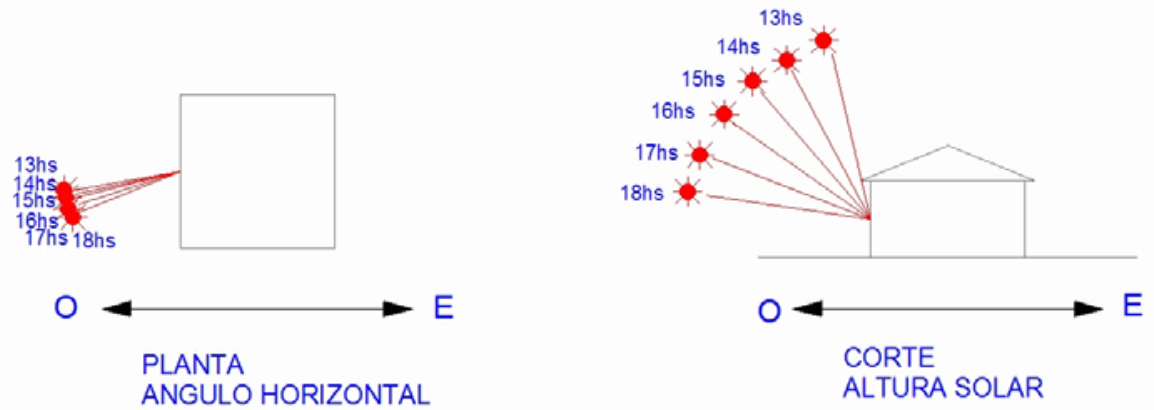

FACHADA OESTE 19 MARÇO
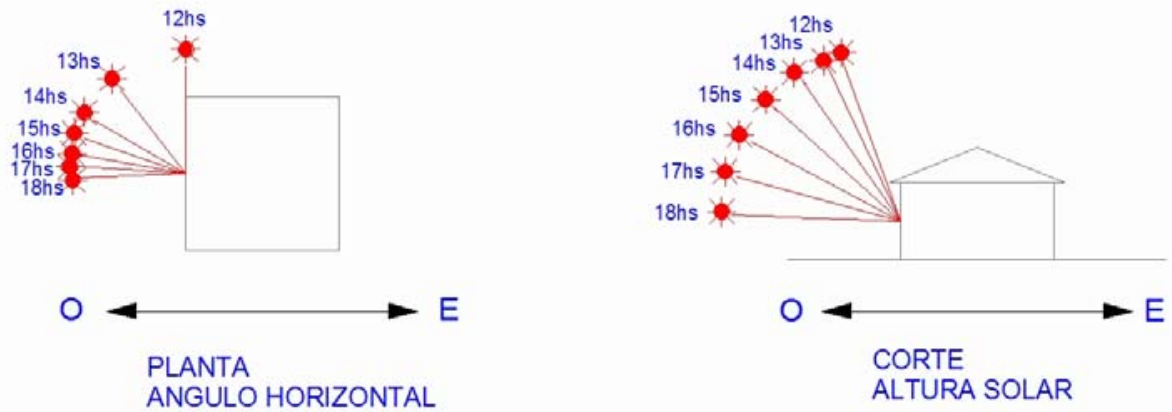

Figura 7. 8 - Ângulos de incidência solar na fachada Oeste. 


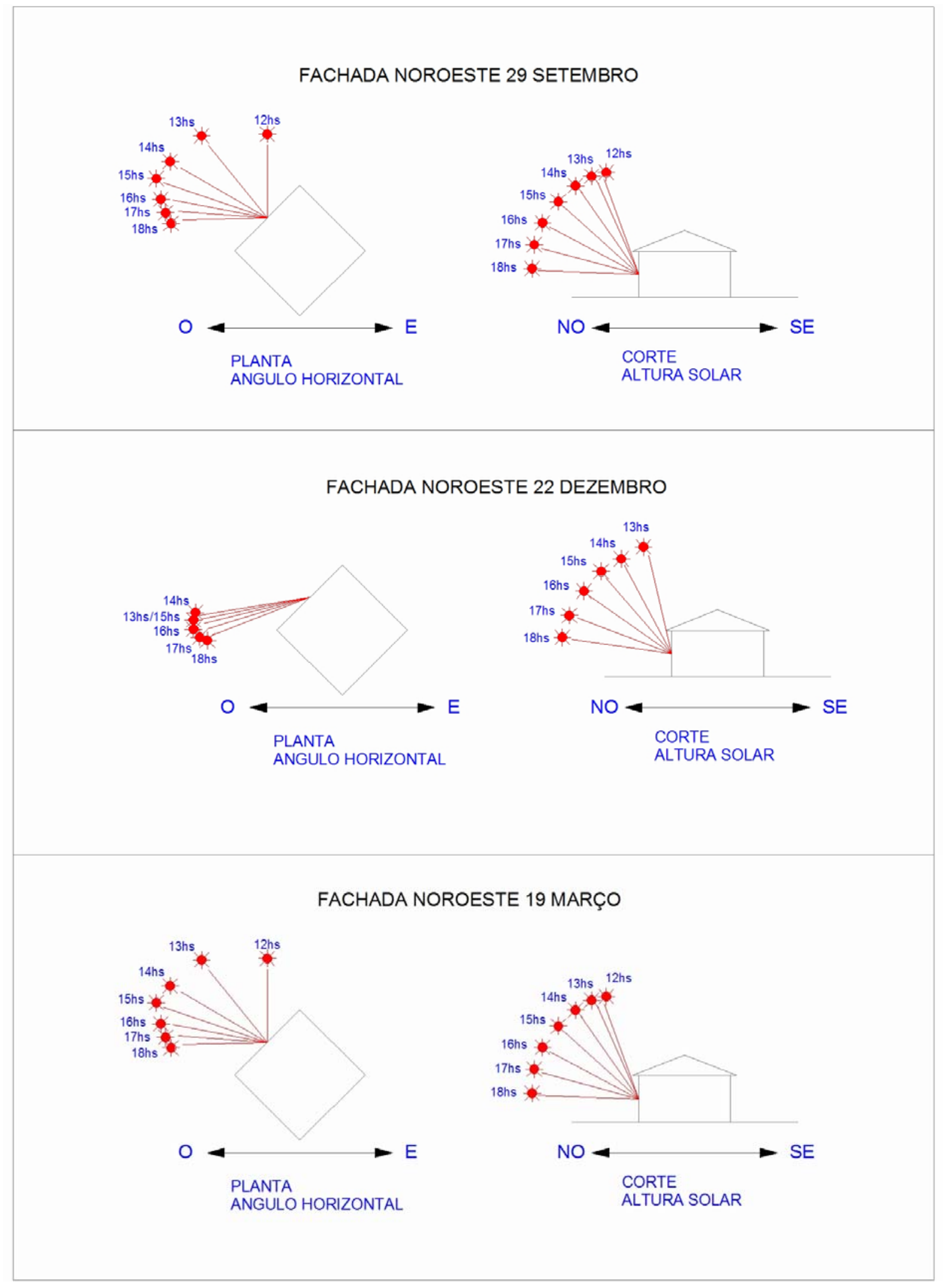

Figura 7. 9 - Ângulos de incidência solar na fachada Noroeste. 
Se uma superfície recebe insolação direta no período da tarde, os picos de quantidades de Watts recebidos por radiação coincidem com os picos de temperatura, resultando no aumento excessivo de temperatura, o que é prejudicial ao conforto em climas quentes como o da cidade de Ribeirão Preto. Para avaliar o comportamento de cada orientação de fachada no período diurno, quando as temperaturas são mais altas, foram comparados os dados de radiação global incidente $(\mathrm{lg})$ com dados de temperatura $(\mathrm{T})$ para cada hora $(\mathrm{h})$ do dia (tabelas $7.5 \mathrm{a}$ 7.31). Foram considerados os meses de Setembro, Dezembro e Março por compreenderem o período mais quente do ano e também devido à disponibilidade de dados de radiação somente para estes meses. Os dados diários de temperatura (T), com medição de hora em hora, foram obtidos na estação meteorológica da UNAERP. Dentre os anos disponíveis, de 2000 a 2006, optou-se por utilizar os dados do ano de 2002 devido a este ano apresentar dados médios com maior similaridade aos dados médios da estação do IAC. Para se determinar os horários com temperaturas mais elevadas, foram considerados valores iguais ou maiores a $30^{\circ} \mathrm{C}$, com arredondamento da ordem de $0,5^{\circ} \mathrm{C}$. Os dados de radiação global $(\mathrm{lg})$, que engloba os valores de radiação direta e difusa, foram obtidos em Frota (2004). Para se determinar os horários com maior incidência de radiação, foram considerados valores iguais ou maiores a $150 \mathrm{~W} / \mathrm{m}^{2}$, pois valores em torno deste apontam a incidência de radiação direta, como se vê nos traçados solares feitos anteriormente. 


\subsubsection{Fachada Norte}

29 de Setembro: intervalo de incidência solar direta: 06h15min às $17 \mathrm{~h} 45 \mathrm{~min}$ - Total $11 \mathrm{~h} 30 \mathrm{~min}$

Tabela 7.5: Fachada Norte - radiação global $(\mathrm{Ig}) \mathrm{X}$ temperatura do ar $(\mathrm{T})$ durante o dia em 29 de Setembro

\begin{tabular}{|c|c|c|c|c|c|c|c|c|c|c|c|c|c|c|}
\hline $\mathrm{h}$ & $06 \mathrm{~h}$ & $07 \mathrm{~h}$ & $08 \mathrm{~h}$ & $09 \mathrm{~h}$ & $10 \mathrm{~h}$ & $11 \mathrm{~h}$ & $12 \mathrm{~h}$ & $13 \mathrm{~h}$ & $14 \mathrm{~h}$ & $15 \mathrm{~h}$ & $16 \mathrm{~h}$ & $17 \mathrm{~h}$ & $18 \mathrm{~h}$ & total \\
\hline $\begin{array}{c}\mathrm{Ig} \\
\left(\mathrm{W} / \mathrm{m}^{2}\right)\end{array}$ & 88 & 203 & 229 & 189 & 155 & 135 & 127 & 135 & 155 & 189 & 229 & 203 & 88 & 2125 \\
\hline $\mathrm{T}\left({ }^{\circ} \mathrm{C}\right)$ & 19,2 & 20,1 & 22,7 & 24,8 & 26,9 & 28,9 & 30,5 & 31,0 & 31,5 & 32,3 & 32,2 & 31,4 & 30,3 & \\
\hline
\end{tabular}

22 de Dezembro: intervalo de incidência solar direta: não recebe insolação direta

Tabela 7.6: Fachada Norte - radiação global (Ig) X temperatura do ar (T) durante o dia em 22 de Dezembro

\begin{tabular}{|c|l|l|l|l|l|l|l|l|l|l|l|l|l|l|}
\hline $\mathrm{h}$ & $06 \mathrm{~h}$ & $07 \mathrm{~h}$ & $08 \mathrm{~h}$ & $09 \mathrm{~h}$ & $10 \mathrm{~h}$ & $11 \mathrm{~h}$ & $12 \mathrm{~h}$ & $13 \mathrm{~h}$ & $14 \mathrm{~h}$ & $15 \mathrm{~h}$ & $16 \mathrm{~h}$ & $17 \mathrm{~h}$ & $18 \mathrm{~h}$ & total \\
\hline $\begin{array}{c}\mathrm{lg} \\
\left(\mathrm{W} / \mathrm{m}^{2}\right)\end{array}$ & 20 & 38 & 50 & 58 & 63 & 68 & 65 & 68 & 63 & 58 & 50 & 38 & 20 & 659 \\
\hline $\mathrm{T}\left({ }^{\circ} \mathrm{C}\right)$ & 20,5 & 20,1 & 20,6 & 23,6 & 25,3 & 26,4 & 27,8 & 28,5 & 29,6 & 30,1 & 30,7 & 31,4 & 29,9 & \\
\hline
\end{tabular}

19 de Março: intervalo de incidência solar direta: 06h15min às 17h45min - Total $11 \mathrm{~h} 30 \mathrm{~min}$

Tabela 7.7: Fachada Norte - radiação global $(\mathrm{Ig}) \mathrm{X}$ temperatura do ar (T) durante o dia em 19 de Março

\begin{tabular}{|c|l|l|l|l|l|l|l|l|l|l|l|l|l|l|}
\hline $\mathrm{h}$ & $06 \mathrm{~h}$ & $07 \mathrm{~h}$ & $08 \mathrm{~h}$ & $09 \mathrm{~h}$ & $10 \mathrm{~h}$ & $11 \mathrm{~h}$ & $12 \mathrm{~h}$ & $13 \mathrm{~h}$ & $14 \mathrm{~h}$ & $15 \mathrm{~h}$ & $16 \mathrm{~h}$ & $17 \mathrm{~h}$ & $18 \mathrm{~h}$ & total \\
\hline $\begin{array}{c}\mathrm{lg} \\
\left(\mathrm{W} / \mathrm{m}^{2}\right)\end{array}$ & 88 & 203 & 229 & 189 & 155 & 135 & 127 & 135 & 155 & 189 & 229 & 203 & 88 & 2125 \\
\hline $\mathrm{T}\left({ }^{\circ} \mathrm{C}\right)$ & 21,3 & 21,4 & 23,3 & 26,1 & 27,4 & 29,1 & 29,7 & 30,7 & 31,0 & 31,2 & 30,3 & 30,8 & 29,9 & \\
\hline
\end{tabular}




\subsubsection{Fachada Nordeste}

29 de Setembro: Intervalo de incidência solar direta: 6h00min às 13h15min - Total 7h15min

Tabela 7.8: Fachada Nordeste - radiação global $(\mathrm{Ig}) \mathrm{X}$ temperatura do $\operatorname{ar}(\mathrm{T})$ durante o dia em 29 de Setembro

\begin{tabular}{|c|l|l|l|l|l|l|l|l|l|l|l|l|l|l|}
\hline $\mathrm{H}$ & $06 \mathrm{~h}$ & $07 \mathrm{~h}$ & $08 \mathrm{~h}$ & $09 \mathrm{~h}$ & $10 \mathrm{~h}$ & $11 \mathrm{~h}$ & $12 \mathrm{~h}$ & $13 \mathrm{~h}$ & $14 \mathrm{~h}$ & $15 \mathrm{~h}$ & $16 \mathrm{~h}$ & $17 \mathrm{~h}$ & $18 \mathrm{~h}$ & total \\
\hline $\begin{array}{c}\mathrm{Ig} \\
\left(\mathrm{W} / \mathrm{m}^{2}\right)\end{array}$ & 93 & 289 & 407 & 402 & 341 & 222 & 68 & 65 & 60 & 53 & 45 & 28 & 0 & 2074 \\
\hline $\mathrm{T}\left({ }^{\circ} \mathrm{C}\right)$ & 19,2 & 20,1 & 22,7 & 24,8 & 26,9 & 28,9 & 30,5 & 31,0 & 31,5 & 32,3 & 32,2 & 31,4 & 30,3 & \\
\hline
\end{tabular}

22 de Dezembro: Intervalo de incidência solar direta: 6h00min às $11 \mathrm{~h} 45 \mathrm{~min}$ - Total $5 \mathrm{~h} 45 \mathrm{~min}$

Tabela 7.9: Fachada Nordeste - radiação global (Ig) X temperatura do ar (T) durante o dia em 22 de Dezembro

\begin{tabular}{|c|l|l|l|l|l|l|l|l|l|l|l|l|l|l|}
\hline $\mathrm{H}$ & $06 \mathrm{~h}$ & $07 \mathrm{~h}$ & $08 \mathrm{~h}$ & $09 \mathrm{~h}$ & $10 \mathrm{~h}$ & $11 \mathrm{~h}$ & $12 \mathrm{~h}$ & $13 \mathrm{~h}$ & $14 \mathrm{~h}$ & $15 \mathrm{~h}$ & $16 \mathrm{~h}$ & $17 \mathrm{~h}$ & $18 \mathrm{~h}$ & total \\
\hline $\begin{array}{c}\mathrm{Ig} \\
\left(\mathrm{W} / \mathrm{m}^{2}\right)\end{array}$ & 114 & 299 & 412 & 407 & 344 & 225 & 65 & 68 & 63 & 58 & 50 & 38 & 20 & 2163 \\
\hline $\mathrm{T}\left({ }^{\circ} \mathrm{C}\right)$ & 20,5 & 20,1 & 20,6 & 23,6 & 25,3 & 26,4 & 27,8 & 28,5 & 29,6 & 30,1 & 30,7 & 31,4 & 29,9 & \\
\hline
\end{tabular}

19 de Março: Intervalo de incidência solar direta: 6h00min às 13h15min - Total 7h15min

Tabela 7.10: Fachada Nordeste - radiação global $(\mathrm{lg}) \mathrm{X}$ temperatura do ar $(\mathrm{T})$ durante o dia em 19 de Março

\begin{tabular}{|c|l|l|l|l|l|l|l|l|l|l|l|l|l|l|}
\hline $\mathrm{H}$ & $06 \mathrm{~h}$ & $07 \mathrm{~h}$ & $08 \mathrm{~h}$ & $09 \mathrm{~h}$ & $10 \mathrm{~h}$ & $11 \mathrm{~h}$ & $12 \mathrm{~h}$ & $13 \mathrm{~h}$ & $14 \mathrm{~h}$ & $15 \mathrm{~h}$ & $16 \mathrm{~h}$ & $17 \mathrm{~h}$ & $18 \mathrm{~h}$ & total \\
\hline $\begin{array}{c}\mathrm{Ig} \\
\left(\mathrm{W} / \mathrm{m}^{2}\right)\end{array}$ & 93 & 289 & 407 & 402 & 341 & 222 & 68 & 65 & 60 & 53 & 45 & 28 & 0 & 2074 \\
\hline $\mathrm{T}\left({ }^{\circ} \mathrm{C}\right)$ & 21,3 & 21,4 & 23,3 & 26,1 & 27,4 & 29,1 & 29,7 & 30,7 & 31,0 & 31,2 & 30,3 & 30,8 & 29,9 & \\
\hline
\end{tabular}




\subsubsection{Fachada Leste}

29 de Setembro: Intervalo de incidência solar direta: 6h00min às $12 \mathrm{~h} 00 \mathrm{~min}$ - Total $6 \mathrm{~h}$

Tabela 7.11: Fachada Leste - radiação global $(\mathrm{Ig}) X$ temperatura do $\operatorname{ar}(\mathrm{T})$ durante o dia em 29 de Setembro

\begin{tabular}{|c|c|c|c|c|c|c|c|c|c|c|c|c|c|c|}
\hline $\mathrm{H}$ & $06 \mathrm{~h}$ & $07 \mathrm{~h}$ & $08 \mathrm{~h}$ & $09 \mathrm{~h}$ & $10 \mathrm{~h}$ & $11 \mathrm{~h}$ & $12 \mathrm{~h}$ & $13 \mathrm{~h}$ & $14 \mathrm{~h}$ & $15 \mathrm{~h}$ & $16 \mathrm{~h}$ & $17 \mathrm{~h}$ & $18 \mathrm{~h}$ & total \\
\hline $\begin{array}{c}\mathrm{Ig} \\
\left(\mathrm{W} / \mathrm{m}^{2}\right)\end{array}$ & 221 & 573 & 741 & 652 & 508 & 306 & 68 & 65 & 60 & 53 & 45 & 28 & 0 & 3320 \\
\hline $\mathrm{T}\left({ }^{\circ} \mathrm{C}\right)$ & 19,2 & 20,1 & 22,7 & 24,8 & 26,9 & 28,9 & 30,5 & 31,0 & 31,5 & 32,3 & 32,2 & 31,4 & 30,3 & \\
\hline
\end{tabular}

22 de Dezembro: Intervalo de incidência solar direta: 6h00min às $12 \mathrm{~h} 00 \mathrm{~min}$ - Total $6 \mathrm{~h}$

Tabela 7.12: Fachada Leste - radiação global $(\mathrm{lg}) \mathrm{X}$ temperatura do ar $(\mathrm{T})$ durante o dia em 22 de Dezembro

\begin{tabular}{|c|l|l|l|l|l|l|l|l|l|l|l|l|l|l|}
\hline $\mathrm{H}$ & $06 \mathrm{~h}$ & $07 \mathrm{~h}$ & $08 \mathrm{~h}$ & $09 \mathrm{~h}$ & $10 \mathrm{~h}$ & $11 \mathrm{~h}$ & $12 \mathrm{~h}$ & $13 \mathrm{~h}$ & $14 \mathrm{~h}$ & $15 \mathrm{~h}$ & $16 \mathrm{~h}$ & $17 \mathrm{~h}$ & $18 \mathrm{~h}$ & total \\
\hline $\begin{array}{c}\mathrm{Ig} \\
\left(\mathrm{W} / \mathrm{m}^{2}\right)\end{array}$ & 241 & 583 & 746 & 657 & 511 & 309 & 65 & 68 & 63 & 58 & 50 & 38 & 20 & 3409 \\
\hline $\mathrm{T}\left({ }^{\circ} \mathrm{C}\right)$ & 20,5 & 20,1 & 20,6 & 23,6 & 25,3 & 26,4 & 27,8 & 28,5 & 29,6 & 30,1 & 30,7 & 31,4 & 29,9 & \\
\hline
\end{tabular}

19 de Março: Intervalo de incidência solar direta: 6h00min às 12h00min - Total 6h

Tabela 7.13: Fachada Leste - radiação global $(\mathrm{lg}) \mathrm{X}$ temperatura do ar $(\mathrm{T})$ durante o dia em 19 de Março

\begin{tabular}{|c|l|l|l|l|l|l|l|l|l|l|l|l|l|l|}
\hline $\mathrm{h}$ & $06 \mathrm{~h}$ & $07 \mathrm{~h}$ & $08 \mathrm{~h}$ & $09 \mathrm{~h}$ & $10 \mathrm{~h}$ & $11 \mathrm{~h}$ & $12 \mathrm{~h}$ & $13 \mathrm{~h}$ & $14 \mathrm{~h}$ & $15 \mathrm{~h}$ & $16 \mathrm{~h}$ & $17 \mathrm{~h}$ & $18 \mathrm{~h}$ & total \\
\hline $\begin{array}{c}\mathrm{lg} \\
\left(\mathrm{W} / \mathrm{m}^{2}\right)\end{array}$ & 221 & 573 & 741 & 652 & 508 & 306 & 68 & 65 & 60 & 53 & 45 & 28 & 0 & 3320 \\
\hline $\mathrm{T}\left({ }^{\circ} \mathrm{C}\right)$ & 21,3 & 21,4 & 23,3 & 26,1 & 27,4 & 29,1 & 29,7 & 30,7 & 31,0 & 31,2 & 30,3 & 30,8 & 29,9 & \\
\hline
\end{tabular}




\subsubsection{Fachada Sudeste}

29 de Setembro: Intervalo de incidência solar direta: 6h00min às 10h45min - Total $4 \mathrm{~h} 45 \mathrm{~min}$

Tabela 7.14: Fachada Sudeste - radiação global (Ig) X temperatura do ar (T) durante o dia em 29 de Setembro

\begin{tabular}{|c|c|c|c|c|c|c|c|c|c|c|c|c|c|c|}
\hline $\mathrm{h}$ & $06 \mathrm{~h}$ & $07 \mathrm{~h}$ & $08 \mathrm{~h}$ & $09 \mathrm{~h}$ & $10 \mathrm{~h}$ & $11 \mathrm{~h}$ & $12 \mathrm{~h}$ & $13 \mathrm{~h}$ & $14 \mathrm{~h}$ & $15 \mathrm{~h}$ & $16 \mathrm{~h}$ & $17 \mathrm{~h}$ & $18 \mathrm{~h}$ & total \\
\hline $\begin{array}{c}\mathrm{Ig} \\
\left(\mathrm{W} / \mathrm{m}^{2}\right)\end{array}$ & 219 & 537 & 668 & 573 & 443 & 285 & 110 & 65 & 60 & 53 & 45 & 28 & 0 & 3086 \\
\hline $\mathrm{T}\left({ }^{\circ} \mathrm{C}\right)$ & 19,2 & 20,1 & 22,7 & 24,8 & 26,9 & 28,9 & 30,5 & 31,0 & 31,5 & 32,3 & 32,2 & 31,4 & 30,3 & \\
\hline
\end{tabular}

22 de Dezembro: Intervalo de incidência solar direta: 6h00min às 12h15min - Total $6 \mathrm{~h} 15 \mathrm{~min}$

Tabela 7.15: Fachada Sudeste - radiação global $(\mathrm{lg}) \mathrm{X}$ temperatura do ar (T) durante o dia em 22 de Dezembro

\begin{tabular}{|c|l|l|l|l|l|l|l|l|l|l|l|l|l|l|}
\hline $\mathrm{h}$ & $06 \mathrm{~h}$ & $07 \mathrm{~h}$ & $08 \mathrm{~h}$ & $09 \mathrm{~h}$ & $10 \mathrm{~h}$ & $11 \mathrm{~h}$ & $12 \mathrm{~h}$ & $13 \mathrm{~h}$ & $14 \mathrm{~h}$ & $15 \mathrm{~h}$ & $16 \mathrm{~h}$ & $17 \mathrm{~h}$ & $18 \mathrm{~h}$ & total \\
\hline $\begin{array}{c}\mathrm{Ig} \\
\left(\mathrm{W} / \mathrm{m}^{2}\right)\end{array}$ & 239 & 547 & 673 & 578 & 446 & 288 & 107 & 68 & 63 & 58 & 50 & 38 & 20 & 3175 \\
\hline $\mathrm{T}\left({ }^{\circ} \mathrm{C}\right)$ & 20,5 & 20,1 & 20,6 & 23,6 & 25,3 & 26,4 & 27,8 & 28,5 & 29,6 & 30,1 & 30,7 & 31,4 & 29,9 & \\
\hline
\end{tabular}

19 de Março: Intervalo de incidência solar direta: 6h00min às 10h45min - Total $4 \mathrm{~h} 45 \mathrm{~min}$

Tabela 7.16: Fachada Sudeste - radiação global $(\mathrm{lg}) \mathrm{X}$ temperatura do $\operatorname{ar}(\mathrm{T})$ durante o dia em 19 de Março

\begin{tabular}{|c|l|l|l|l|l|l|l|l|l|l|l|l|l|l|}
\hline $\mathrm{h}$ & $06 \mathrm{~h}$ & $07 \mathrm{~h}$ & $08 \mathrm{~h}$ & $09 \mathrm{~h}$ & $10 \mathrm{~h}$ & $11 \mathrm{~h}$ & $12 \mathrm{~h}$ & $13 \mathrm{~h}$ & $14 \mathrm{~h}$ & $15 \mathrm{~h}$ & $16 \mathrm{~h}$ & $17 \mathrm{~h}$ & $18 \mathrm{~h}$ & total \\
\hline $\begin{array}{c}\mathrm{lg} \\
\left(\mathrm{W} / \mathrm{m}^{2}\right)\end{array}$ & 219 & 537 & 668 & 573 & 443 & 285 & 110 & 65 & 60 & 53 & 45 & 28 & 0 & 3086 \\
\hline $\mathrm{T}\left({ }^{\circ} \mathrm{C}\right)$ & 21,3 & 21,4 & 23,3 & 26,1 & 27,4 & 29,1 & 29,7 & 30,7 & 31,0 & 31,2 & 30,3 & 30,8 & 29,9 & \\
\hline
\end{tabular}




\subsubsection{Fachada Sul}

29 de Setembro: Intervalo de incidência solar direta: não ocorre

Tabela 7.17: Fachada Sul - radiação global $(\mathrm{Ig}) \mathrm{X}$ temperatura do ar $(\mathrm{T})$ durante o dia em 29 de Setembro

\begin{tabular}{|c|l|l|l|l|l|l|l|l|l|l|l|l|l|l|}
\hline $\mathrm{h}$ & $06 \mathrm{~h}$ & $07 \mathrm{~h}$ & $08 \mathrm{~h}$ & $09 \mathrm{~h}$ & $10 \mathrm{~h}$ & $11 \mathrm{~h}$ & $12 \mathrm{~h}$ & $13 \mathrm{~h}$ & $14 \mathrm{~h}$ & $15 \mathrm{~h}$ & $16 \mathrm{~h}$ & $17 \mathrm{~h}$ & $18 \mathrm{~h}$ & total \\
\hline $\begin{array}{c}\mathrm{lg} \\
\left(\mathrm{W} / \mathrm{m}^{2}\right)\end{array}$ & 0 & 28 & 45 & 53 & 60 & 65 & 68 & 65 & 60 & 53 & 45 & 28 & 0 & 570 \\
\hline $\mathrm{T}\left({ }^{\circ} \mathrm{C}\right)$ & 19,2 & 20,1 & 22,7 & 24,8 & 26,9 & 28,9 & 30,5 & 31,0 & 31,5 & 32,3 & 32,2 & 31,4 & 30,3 & \\
\hline
\end{tabular}

22 de Dezembro: Intervalo de incidência solar direta: 6h00min às 18h00min - Total $12 \mathrm{~h}$

Tabela 7.18: Fachada Sul - radiação global $(\mathrm{Ig}) \mathrm{X}$ temperatura do ar $(\mathrm{T})$ durante o dia em 22 de Dezembro

\begin{tabular}{|c|c|c|c|c|c|c|c|c|c|c|c|c|c|c|}
\hline $\mathrm{h}$ & $06 \mathrm{~h}$ & $07 \mathrm{~h}$ & $08 \mathrm{~h}$ & $09 \mathrm{~h}$ & $10 \mathrm{~h}$ & $11 \mathrm{~h}$ & $12 \mathrm{~h}$ & $13 \mathrm{~h}$ & $14 \mathrm{~h}$ & $15 \mathrm{~h}$ & $16 \mathrm{~h}$ & $17 \mathrm{~h}$ & $18 \mathrm{~h}$ & total \\
\hline $\begin{array}{c}\mathrm{Ig} \\
\left(\mathrm{W} / \mathrm{m}^{2}\right)\end{array}$ & 108 & 213 & 234 & 194 & 158 & 138 & 124 & 138 & 158 & 194 & 234 & 213 & 108 & 2214 \\
\hline $\mathrm{T}\left({ }^{\circ} \mathrm{C}\right)$ & 20,5 & 20,1 & 20,6 & 23,6 & 25,3 & 26,4 & 27,8 & 28,5 & 29,6 & 30,1 & 30,7 & 31,4 & 29,9 & \\
\hline
\end{tabular}

19 de Março: Intervalo de incidência solar direta: não ocorre

Tabela 7.19: Fachada Sul - radiação global $(\mathrm{Ig}) \mathrm{X}$ temperatura do ar $(\mathrm{T})$ durante o dia em 19 de Março

\begin{tabular}{|c|c|c|c|c|c|c|c|c|c|c|c|c|c|c|}
\hline $\mathrm{h}$ & $06 \mathrm{~h}$ & $07 \mathrm{~h}$ & $08 \mathrm{~h}$ & $09 \mathrm{~h}$ & $10 \mathrm{~h}$ & $11 \mathrm{~h}$ & $12 \mathrm{~h}$ & $13 \mathrm{~h}$ & $14 \mathrm{~h}$ & $15 \mathrm{~h}$ & $16 \mathrm{~h}$ & $17 \mathrm{~h}$ & $18 \mathrm{~h}$ & total \\
\hline $\begin{array}{c}\mathrm{lg} \\
\left(\mathrm{W} / \mathrm{m}^{2}\right)\end{array}$ & 0 & 28 & 45 & 53 & 60 & 65 & 68 & 65 & 60 & 53 & 45 & 28 & 0 & 570 \\
\hline $\mathrm{T}\left({ }^{\circ} \mathrm{C}\right)$ & 21,3 & 21,4 & 23,3 & 26,1 & 27,4 & 29,1 & 29,7 & 30,7 & 31,0 & 31,2 & 30,3 & 30,8 & 29,9 & \\
\hline
\end{tabular}




\subsubsection{Fachada Sudoeste}

29 de Setembro: Intervalo de incidência solar direta: 13h15min às $18 \mathrm{~h} 00 \mathrm{~min}$ - Total $4 \mathrm{~h} 45 \mathrm{~min}$

Tabela 7.20: Fachada Sudoeste - radiação global $(\mathrm{lg}) \mathrm{X}$ temperatura do $\operatorname{ar}(\mathrm{T})$ durante o dia em 29 de Setembro

\begin{tabular}{|c|l|l|l|l|l|l|l|l|l|l|l|l|l|l|}
\hline $\mathrm{h}$ & $06 \mathrm{~h}$ & $07 \mathrm{~h}$ & $08 \mathrm{~h}$ & $09 \mathrm{~h}$ & $10 \mathrm{~h}$ & $11 \mathrm{~h}$ & $12 \mathrm{~h}$ & $13 \mathrm{~h}$ & $14 \mathrm{~h}$ & $15 \mathrm{~h}$ & $16 \mathrm{~h}$ & $17 \mathrm{~h}$ & $18 \mathrm{~h}$ & total \\
\hline $\begin{array}{c}\mathrm{Ig} \\
\left(\mathrm{W} / \mathrm{m}^{2}\right)\end{array}$ & 0 & 28 & 45 & 53 & 60 & 65 & 110 & 285 & 443 & 573 & 668 & 537 & 219 & 3086 \\
\hline $\mathrm{T}\left({ }^{\circ} \mathrm{C}\right)$ & 19,2 & 20,1 & 22,7 & 24,8 & 26,9 & 28,9 & 30,5 & 31,0 & 31,5 & 32,3 & 32,2 & 31,4 & 30,3 & \\
\hline
\end{tabular}

22 de Dezembro: Intervalo de incidência solar direta: 11h45min às $18 \mathrm{~h} 00 \mathrm{~min}-$ Total $6 \mathrm{~h} 15 \mathrm{~min}$

Tabela 7.21: Fachada Sudoeste - radiação global (Ig) X temperatura do ar (T) durante o dia em 22 de Dezembro

\begin{tabular}{|c|l|l|l|l|l|l|l|l|l|l|l|l|l|l|}
\hline $\mathrm{h}$ & $06 \mathrm{~h}$ & $07 \mathrm{~h}$ & $08 \mathrm{~h}$ & $09 \mathrm{~h}$ & $10 \mathrm{~h}$ & $11 \mathrm{~h}$ & $12 \mathrm{~h}$ & $13 \mathrm{~h}$ & $14 \mathrm{~h}$ & $15 \mathrm{~h}$ & $16 \mathrm{~h}$ & $17 \mathrm{~h}$ & $18 \mathrm{~h}$ & total \\
\hline $\begin{array}{c}\mathrm{Ig} \\
\left(\mathrm{W} / \mathrm{m}^{2}\right)\end{array}$ & 20 & 38 & 50 & 58 & 63 & 68 & 107 & 288 & 446 & 578 & 673 & 547 & 239 & 3175 \\
\hline $\mathrm{T}\left({ }^{\circ} \mathrm{C}\right)$ & 20,5 & 20,1 & 20,6 & 23,6 & 25,3 & 26,4 & 27,8 & 28,5 & 29,6 & 30,1 & 30,7 & 31,4 & 29,9 & \\
\hline
\end{tabular}

19 de Março: Intervalo de incidência solar direta: $13 \mathrm{~h} 15 \mathrm{~min}$ às $18 \mathrm{~h} 00 \mathrm{~min}$ - Total $4 \mathrm{~h} 45 \mathrm{~min}$

Tabela 7.22: Fachada Sudoeste - radiação global (Ig) X temperatura do ar ( $\mathrm{T}$ ) durante o dia em 19 de Março

\begin{tabular}{|c|c|c|c|c|c|c|c|c|c|c|c|c|c|c|}
\hline $\mathrm{h}$ & $06 \mathrm{~h}$ & $07 \mathrm{~h}$ & $08 \mathrm{~h}$ & $09 \mathrm{~h}$ & $10 \mathrm{~h}$ & $11 \mathrm{~h}$ & $12 \mathrm{~h}$ & $13 \mathrm{~h}$ & $14 \mathrm{~h}$ & $15 \mathrm{~h}$ & $16 \mathrm{~h}$ & $17 \mathrm{~h}$ & $18 \mathrm{~h}$ & total \\
\hline $\begin{array}{c}\mathrm{lg} \\
\left(\mathrm{W} / \mathrm{m}^{2}\right)\end{array}$ & 0 & 28 & 45 & 53 & 60 & 65 & 110 & 285 & 443 & 573 & 668 & 537 & 219 & 3086 \\
\hline $\mathrm{T}\left({ }^{\circ} \mathrm{C}\right)$ & 21,3 & 21,4 & 23,3 & 26,1 & 27,4 & 29,1 & 29,7 & 30,7 & 31,0 & 31,2 & 30,3 & 30,8 & 29,9 & \\
\hline
\end{tabular}




\subsubsection{Fachada Oeste}

29 de Setembro: Intervalo de incidência solar direta: $12 \mathrm{~h} 00 \mathrm{~min}$ às $18 \mathrm{~h} 00 \mathrm{~min}$ - Total $6 \mathrm{~h}$

Tabela 7.23: Fachada Oeste - radiação global $(\mathrm{Ig}) \mathrm{X}$ temperatura do ar $(\mathrm{T})$ durante o dia em 29 de Setembro

\begin{tabular}{|c|l|l|l|l|l|l|l|l|l|l|l|l|l|l|}
\hline $\mathrm{h}$ & $06 \mathrm{~h}$ & $07 \mathrm{~h}$ & $08 \mathrm{~h}$ & $09 \mathrm{~h}$ & $10 \mathrm{~h}$ & $11 \mathrm{~h}$ & $12 \mathrm{~h}$ & $13 \mathrm{~h}$ & $14 \mathrm{~h}$ & $15 \mathrm{~h}$ & $16 \mathrm{~h}$ & $17 \mathrm{~h}$ & $18 \mathrm{~h}$ & total \\
\hline $\begin{array}{c}\mathrm{Ig} \\
\left(\mathrm{W} / \mathrm{m}^{2}\right)\end{array}$ & 0 & 28 & 45 & 53 & 60 & 65 & 68 & 306 & 508 & 652 & 741 & 573 & 221 & 3320 \\
\hline $\mathrm{T}\left({ }^{\circ} \mathrm{C}\right)$ & 19,2 & 20,1 & 22,7 & 24,8 & 26,9 & 28,9 & 30,5 & 31,0 & 31,5 & 32,3 & 32,2 & 31,4 & 30,3 & \\
\hline
\end{tabular}

22 de Dezembro: Intervalo de incidência solar direta: 12h00min às $18 \mathrm{~h} 00 \mathrm{~min}-$ Total $6 \mathrm{~h}$

Tabela 7.24: Fachada Oeste - radiação global (Ig) X temperatura do ar (T) durante o dia em 22 de Dezembro

\begin{tabular}{|c|l|l|l|l|l|l|l|l|l|l|l|l|l|l|}
\hline $\mathrm{h}$ & $06 \mathrm{~h}$ & $07 \mathrm{~h}$ & $08 \mathrm{~h}$ & $09 \mathrm{~h}$ & $10 \mathrm{~h}$ & $11 \mathrm{~h}$ & $12 \mathrm{~h}$ & $13 \mathrm{~h}$ & $14 \mathrm{~h}$ & $15 \mathrm{~h}$ & $16 \mathrm{~h}$ & $17 \mathrm{~h}$ & $18 \mathrm{~h}$ & total \\
\hline $\begin{array}{c}\mathrm{Ig} \\
\left(\mathrm{W} / \mathrm{m}^{2}\right)\end{array}$ & 20 & 38 & 50 & 58 & 63 & 68 & 65 & 309 & 511 & 657 & 746 & 583 & 241 & 3409 \\
\hline $\mathrm{T}\left({ }^{\circ} \mathrm{C}\right)$ & 20,5 & 20,1 & 20,6 & 23,6 & 25,3 & 26,4 & 27,8 & 28,5 & 29,6 & 30,1 & 30,7 & 31,4 & 29,9 & \\
\hline
\end{tabular}

19 de Março: Intervalo de incidência solar direta: $12 \mathrm{~h} 00 \mathrm{~min}$ às $18 \mathrm{~h} 00 \mathrm{~min}$ - Total $6 \mathrm{~h}$

Tabela 7.25: Fachada Oeste - radiação global $(\mathrm{Ig}) \mathrm{X}$ temperatura do $\operatorname{ar}(\mathrm{T})$ durante o dia em19 de Março

\begin{tabular}{|c|c|c|c|c|c|c|c|c|c|c|c|c|c|c|}
\hline $\mathrm{H}$ & $06 \mathrm{~h}$ & $07 \mathrm{~h}$ & $08 \mathrm{~h}$ & $09 \mathrm{~h}$ & $10 \mathrm{~h}$ & $11 \mathrm{~h}$ & $12 \mathrm{~h}$ & $13 \mathrm{~h}$ & $14 \mathrm{~h}$ & $15 \mathrm{~h}$ & $16 \mathrm{~h}$ & $17 \mathrm{~h}$ & $18 \mathrm{~h}$ & total \\
\hline $\begin{array}{c}\mathrm{Ig} \\
\left(\mathrm{W} / \mathrm{m}^{2}\right)\end{array}$ & 0 & 28 & 45 & 53 & 60 & 65 & 68 & 306 & 508 & 652 & 741 & 573 & 221 & 3320 \\
\hline $\mathrm{T}\left({ }^{\circ} \mathrm{C}\right)$ & 21,3 & 21,4 & 23,3 & 26,1 & 27,4 & 29,1 & 29,7 & 30,7 & 31,0 & 31,2 & 30,3 & 30,8 & 29,9 & \\
\hline
\end{tabular}




\subsubsection{Fachada Noroeste}

29 de Setembro: Intervalo de incidência solar direta: 10h45min às 18h00min - Total 7h15min

Tabela 7.26: Fachada Noroeste - radiação global $(\mathrm{lg}) \mathrm{X}$ temperatura do $\operatorname{ar}(\mathrm{T})$ durante o dia em 29 de Setembro

\begin{tabular}{|c|l|l|l|l|l|l|l|l|l|l|l|l|l|l|}
\hline $\mathrm{h}$ & $06 \mathrm{~h}$ & $07 \mathrm{~h}$ & $08 \mathrm{~h}$ & $09 \mathrm{~h}$ & $10 \mathrm{~h}$ & $11 \mathrm{~h}$ & $12 \mathrm{~h}$ & $13 \mathrm{~h}$ & $14 \mathrm{~h}$ & $15 \mathrm{~h}$ & $16 \mathrm{~h}$ & $17 \mathrm{~h}$ & $18 \mathrm{~h}$ & total \\
\hline $\begin{array}{c}\mathrm{Ig} \\
\left(\mathrm{W} / \mathrm{m}^{2}\right)\end{array}$ & 0 & 28 & 45 & 53 & 60 & 65 & 68 & 222 & 341 & 402 & 407 & 289 & 94 & 2074 \\
\hline $\mathrm{T}\left({ }^{\circ} \mathrm{C}\right)$ & 19,2 & 20,1 & 22,7 & 24,8 & 26,9 & 28,9 & 30,5 & 31,0 & 31,5 & 32,3 & 32,2 & 31,4 & 30,3 & \\
\hline
\end{tabular}

22 de Dezembro: Intervalo de incidência solar direta: 12h15min às 18h00min - Total $5 \mathrm{~h} 45 \mathrm{~min}$

Tabela 7.27: Fachada Noroeste - radiação global $(\mathrm{lg}) \mathrm{X}$ temperatura do $\operatorname{ar}(\mathrm{T})$ durante o dia em 22 de Dezembro

\begin{tabular}{|c|l|l|l|l|l|l|l|l|l|l|l|l|l|l|}
\hline $\mathrm{h}$ & $06 \mathrm{~h}$ & $07 \mathrm{~h}$ & $08 \mathrm{~h}$ & $09 \mathrm{~h}$ & $10 \mathrm{~h}$ & $11 \mathrm{~h}$ & $12 \mathrm{~h}$ & $13 \mathrm{~h}$ & $14 \mathrm{~h}$ & $15 \mathrm{~h}$ & $16 \mathrm{~h}$ & $17 \mathrm{~h}$ & $18 \mathrm{~h}$ & total \\
\hline $\begin{array}{c}\mathrm{Ig} \\
\left(\mathrm{W} / \mathrm{m}^{2}\right)\end{array}$ & 20 & 38 & 50 & 58 & 63 & 68 & 65 & 225 & 344 & 407 & 412 & 299 & 114 & 2163 \\
\hline $\mathrm{T}\left({ }^{\circ} \mathrm{C}\right)$ & 20,5 & 20,1 & 20,6 & 23,6 & 25,3 & 26,4 & 27,8 & 28,5 & 29,6 & 30,1 & 30,7 & 31,4 & 29,9 & \\
\hline
\end{tabular}

19 de Março: Intervalo de incidência solar direta: 10h45min às 18h00min - Total 7h15min

Tabela 7.28: Fachada Noroeste - radiação global $(\mathrm{lg}) \mathrm{X}$ temperatura do $\operatorname{ar}(\mathrm{T})$ durante o dia em 19 de Março

\begin{tabular}{|c|c|c|c|c|c|c|c|c|c|c|c|c|c|c|}
\hline $\mathrm{h}$ & $06 \mathrm{~h}$ & $07 \mathrm{~h}$ & $08 \mathrm{~h}$ & $09 \mathrm{~h}$ & $10 \mathrm{~h}$ & $11 \mathrm{~h}$ & $12 \mathrm{~h}$ & $13 \mathrm{~h}$ & $14 \mathrm{~h}$ & $15 \mathrm{~h}$ & $16 \mathrm{~h}$ & $17 \mathrm{~h}$ & $18 \mathrm{~h}$ & total \\
\hline $\begin{array}{c}\mathrm{lg} \\
\left(\mathrm{W} / \mathrm{m}^{2}\right)\end{array}$ & 0 & 28 & 45 & 53 & 60 & 65 & 68 & 222 & 341 & 402 & 407 & 289 & 94 & 2074 \\
\hline $\mathrm{T}\left({ }^{\circ} \mathrm{C}\right)$ & 21,3 & 21,4 & 23,3 & 26,1 & 27,4 & 29,1 & 29,7 & 30,7 & 31,0 & 31,2 & 30,3 & 30,8 & 29,9 & \\
\hline
\end{tabular}




\subsubsection{Plano Horizontal (cobertura)}

29 de Setembro: Intervalo de incidência solar direta: 7 h00min às $17 \mathrm{~h} 00 \mathrm{~min}$ - Total $10 \mathrm{~h}$

Tabela 7.29: Plano Horizontal - radiação global $(\mathrm{lg}) \mathrm{X}$ temperatura do ar $(\mathrm{T})$ durante o dia em 29 de Setembro

\begin{tabular}{|c|l|l|l|l|l|l|l|l|l|l|l|l|l|l|}
\hline $\mathrm{h}$ & $06 \mathrm{~h}$ & $07 \mathrm{~h}$ & $08 \mathrm{~h}$ & $09 \mathrm{~h}$ & $10 \mathrm{~h}$ & $11 \mathrm{~h}$ & $12 \mathrm{~h}$ & $13 \mathrm{~h}$ & $14 \mathrm{~h}$ & $15 \mathrm{~h}$ & $16 \mathrm{~h}$ & $17 \mathrm{~h}$ & $18 \mathrm{~h}$ & total \\
\hline $\begin{array}{c}\mathrm{Ig} \\
\left(\mathrm{W} / \mathrm{m}^{2}\right)\end{array}$ & 0 & 157 & 439 & 686 & 897 & 1025 & 1071 & 1025 & 897 & 686 & 439 & 157 & 0 & 7479 \\
\hline $\mathrm{T}\left({ }^{\circ} \mathrm{C}\right)$ & 19,2 & 20,1 & 22,7 & 24,8 & 26,9 & 28,9 & 30,5 & 31,0 & 31,5 & 32,3 & 32,2 & 31,4 & 30,3 & \\
\hline
\end{tabular}

22 de Dezembro: Intervalo de incidência solar direta: 7h00min às 17h00min - Total $10 \mathrm{~h}$

Tabela 7.30: Plano Horizontal - radiação global $(\mathrm{lg}) \mathrm{X}$ temperatura do $\operatorname{ar}(\mathrm{T})$ durante o dia em 22 de Dezembro

\begin{tabular}{|c|c|c|c|c|c|c|c|c|c|c|c|c|c|c|}
\hline $\mathrm{h}$ & $06 \mathrm{~h}$ & $07 \mathrm{~h}$ & $08 \mathrm{~h}$ & $09 \mathrm{~h}$ & $10 \mathrm{~h}$ & $11 \mathrm{~h}$ & $12 \mathrm{~h}$ & $13 \mathrm{~h}$ & $14 \mathrm{~h}$ & $15 \mathrm{~h}$ & $16 \mathrm{~h}$ & $17 \mathrm{~h}$ & $18 \mathrm{~h}$ & total \\
\hline $\begin{array}{c}\mathrm{lg} \\
\left(\mathrm{W} / \mathrm{m}^{2}\right)\end{array}$ & 73 & 289 & 567 & 801 & 985 & 1105 & 1140 & 1105 & 985 & 801 & 567 & 289 & 73 & 8780 \\
\hline $\mathrm{T}\left({ }^{\circ} \mathrm{C}\right)$ & 20,5 & 20,1 & 20,6 & 23,6 & 25,3 & 26,4 & 27,8 & 28,5 & 29,6 & 30,1 & 30,7 & 31,4 & 29,9 & \\
\hline
\end{tabular}

19 de Março: Intervalo de incidência solar direta: 7 h00min às $17 \mathrm{~h} 00 \mathrm{~min}$ - Total $10 \mathrm{~h}$

Tabela 7.31 - Plano Horizontal - radiação global (Ig) X temperatura do ar (T) durante o dia em 19 de Março

\begin{tabular}{|c|c|c|c|c|c|c|c|c|c|c|c|c|c|c|}
\hline $\mathrm{h}$ & $06 \mathrm{~h}$ & $07 \mathrm{~h}$ & $08 \mathrm{~h}$ & $09 \mathrm{~h}$ & $10 \mathrm{~h}$ & $11 \mathrm{~h}$ & $12 \mathrm{~h}$ & $13 \mathrm{~h}$ & $14 \mathrm{~h}$ & $15 \mathrm{~h}$ & $16 \mathrm{~h}$ & $17 \mathrm{~h}$ & $18 \mathrm{~h}$ & total \\
\hline $\begin{array}{c}\mathrm{Ig} \\
\left(\mathrm{W} / \mathrm{m}^{2}\right)\end{array}$ & 0 & 157 & 439 & 686 & 897 & 1025 & 1071 & 1025 & 897 & 686 & 439 & 157 & 0 & 7479 \\
\hline $\mathrm{T}\left({ }^{\circ} \mathrm{C}\right)$ & 21,3 & 21,4 & 23,3 & 26,1 & 27,4 & 29,1 & 29,7 & 30,7 & 31,0 & 31,2 & 30,3 & 30,8 & 29,9 & \\
\hline
\end{tabular}




\subsubsection{Comparação das orientações}

Para se comparar as orientações mais favoráveis do ponto de vista do aumento de temperatura decorrente do ganho de calor por radiação, serão considerados dois critérios. O primeiro é a ocorrência simultânea de picos de temperatura ( $T$ max) com picos de radiação (Ig max) no período da tarde, entre 12h00min e 18h00min (tabela 7.32).

Tabela 7.32: Ocorrência simultânea de Tmax + Ig max para oito orientações e plano horizontal

\begin{tabular}{|c|c|c|c|c|}
\hline & 29 de Setembro & 22 de Dezembro & 19 de Março & Total \\
\hline Norte & $\operatorname{sim}$ & não & $\operatorname{sim}$ & 2 \\
\hline Nordeste & não & não & não & 0 \\
\hline Leste & não & não & não & 0 \\
\hline Sudeste & não & não & não & 0 \\
\hline Sul & não & $\operatorname{sim}$ & não & 1 \\
\hline Sudoeste & $\operatorname{sim}$ & $\operatorname{sim}$ & $\operatorname{sim}$ & 3 \\
\hline Oeste & $\operatorname{sim}$ & $\operatorname{sim}$ & $\operatorname{sim}$ & 3 \\
\hline Noroeste & $\operatorname{sim}$ & $\operatorname{sim}$ & $\operatorname{sim}$ & 3 \\
\hline Horizontal & $\operatorname{sim}$ & $\operatorname{sim}$ & 3 \\
\hline
\end{tabular}

O segundo critério é a quantidade média de radiação em $\mathrm{W} / \mathrm{m}^{2}$ recebida pela fachada durante o período de setembro a março (tabela 7.33).

Tabela 7.33: Média de radiação global recebida para oito orientações e plano horizontal

\begin{tabular}{|c|c|c|c|c|}
\hline & $\begin{array}{c}29 \text { de Setembro } \\
\left(\mathrm{W} / \mathrm{m}^{2}\right)\end{array}$ & $\begin{array}{c}22 \text { de Dezembro } \\
\left(\mathrm{W} / \mathrm{m}^{2}\right)\end{array}$ & $\begin{array}{c}19 \text { de Março } \\
\left(\mathrm{W} / \mathrm{m}^{2}\right)\end{array}$ & $\begin{array}{l}\text { Média } \\
\left(\mathrm{W} / \mathrm{m}^{2}\right)\end{array}$ \\
\hline Norte & 1126 & 362 & 1126 & 871 \\
\hline Nordeste & 319 & 362 & 319 & 333 \\
\hline Leste & 319 & 362 & 319 & 333 \\
\hline Sudeste & 361 & 404 & 361 & 375 \\
\hline Sul & 319 & 1169 & 319 & 602 \\
\hline
\end{tabular}




\begin{tabular}{|c|c|c|c|c|}
\hline Sudoeste & 2835 & 2878 & 2835 & 2849 \\
\hline Oeste & 3069 & 3112 & 3069 & 3083 \\
\hline Noroeste & 1823 & 1866 & 1823 & 1837 \\
\hline Horizontal & 4275 & 4960 & 4275 & 4503 \\
\hline
\end{tabular}

O cruzamento dos dados das duas tabelas acima resultou em uma classificação de orientações que leva em conta a quantidade de ganho de calor no período da tarde, de acordo com o esquema abaixo:

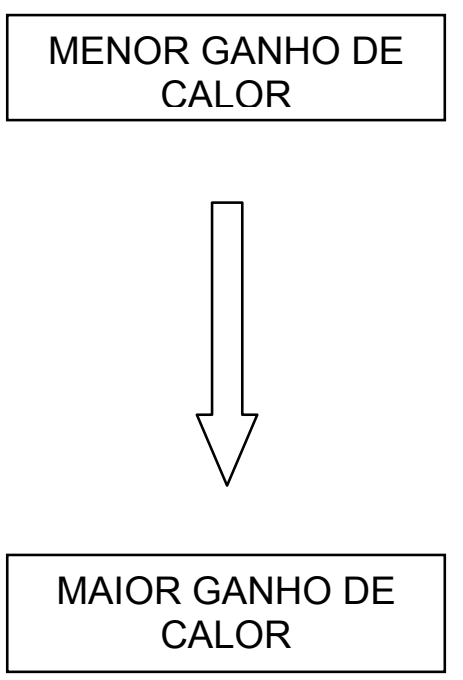

\begin{tabular}{|c|}
\hline Leste \\
\hline Nordeste \\
\hline Sudeste \\
\hline Sul \\
\hline Norte \\
\hline Noroeste \\
\hline Sudoeste \\
\hline Oeste \\
\hline Horizontal \\
\hline
\end{tabular}

Figura 7.10 - Classificação de fachadas segundo ganho de calor por radiação no período da tarde para a latitude de $21^{\circ} 10^{\prime} \mathrm{S}$.

A classificação acima pode auxiliar na tomada de decisões em relação à implantação de edificações no sentido de evitar o sobreaquecimento em ambientes onde este fator seja indesejável e orientar para as fachadas com maior incidência os ambientes onde este fator não seja tão prejudicial.

\subsection{APLICAÇÃO DA NBR 15220}

De acordo com o zoneamento climático da NBR 15220 da ABNT, o município de Ribeirão Preto encontra-se na Zona Bioclimática 4 (figuras 7.11 e 7.12). 


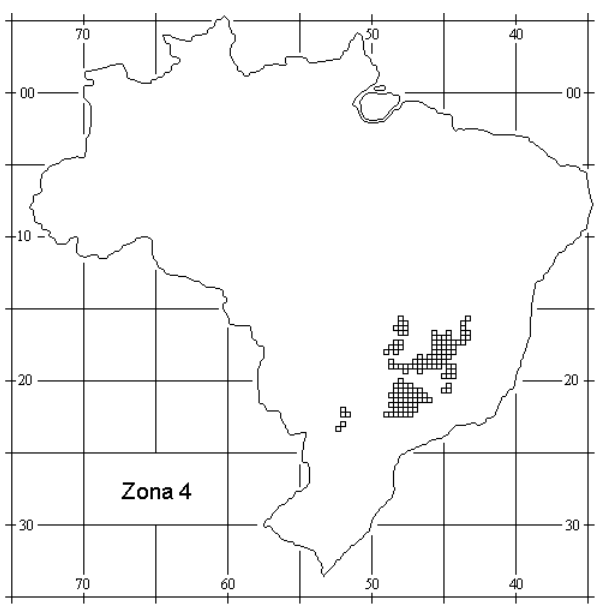

Figura 7.11 Zona Bioclimática4 (NBR15220)

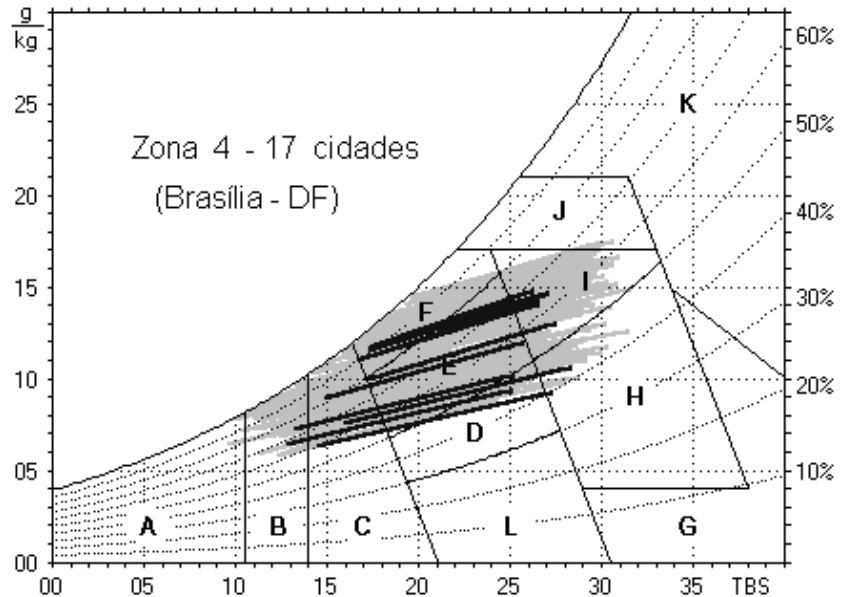

Figura 7.12 Carta Bioclimática para a Zona 4 (NBR15220)

Para a Zona Bioclimática 4, a norma tece as seguintes recomendações em relação às vedações externas: as paredes devem ser pesadas, com Transmitância Térmica $\mathrm{U} \leq 2,20 \mathrm{~W} / \mathrm{m}^{2} \mathrm{~K}$, Atraso Térmico $\varphi \geq 6,5$ horas e Fator de Calor Solar FCS $\leq 3,5 \%$. Em relação ao Fator de Calor Solar das paredes, influenciado principalmente pela cor da superfície, toma-se a fórmula 17 da norma:

FCS $=4 . \mathbf{U} . \mathbf{\alpha}$ sendo $U$ a transmitância térmica do componente e $\mathbf{a}$ a absortância da radiação, que é função da cor.

Para se respeitar o limite máximo de 3,5\% para paredes temos então:

$3,5 \leq 4 . U$. $\alpha$ ou ainda $\alpha \leq 3,5$ / (4 . U)

Aplicando a fórmula acima ao primeiro exemplo, com $U=1,52$ temos:

$$
\begin{aligned}
& \alpha \leq 3,5 /(4 \cdot 1,52) \\
& \alpha \leq 3,5 / 6,08 \\
& \alpha \leq 0,58
\end{aligned}
$$

De acordo com a tabela de absortância B.2 da norma, o tipo de alvenaria em questão admite acabamento em reboco claro ou pintura em cores claras (branca, 
amarela, verde claro ou "alumínio") para que se atenda aos limites da recomendação.

Se considerarmos estes três fatores, as opções construtivas que respeitariam a norma ficam limitadas a alvenarias duplas de tijolos cerâmicos furados, como o exemplo da figura 7.13 .

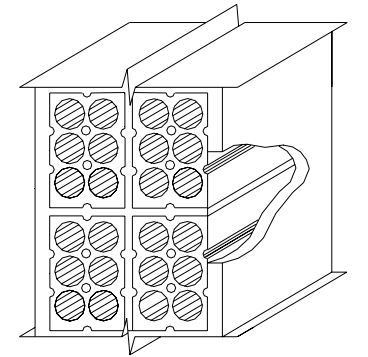

Dimens. tijolo: $10,0 \times 15,0 \times 20,0 \mathrm{~cm}$

Espessura arg. de assent.: $1,0 \mathrm{~cm}$

Espessura arg. de emboço: $2,5 \mathrm{~cm}$

Espessura total da parede: $26,0 \mathrm{~cm}$

$\mathrm{U}=1,52 \mathrm{~W} / \mathrm{m}^{2} . \mathrm{K} / \varphi=6,5$ horas

Figura 7.13 - Parede dupla de tijolos cerâmicos furados assentados na menor dimensão com valores de Transmitância $(U)$ e Atraso Térmico $(\varphi)$.

Porém, a utilização deste tipo de alvenaria pode se mostrar inviável para muitas edificações, o que dificultaria a sua adoção como tipologia construtiva para vedações externas. Pequenas variações numéricas nos valores de Transmitância e Atraso Térmico não necessariamente resultam em alterações sensíveis nas temperaturas dos ambientes internos. Portanto, o mais sensato é avaliar os tipos de alvenaria mais utilizados em Ribeirão Preto e, de acordo com as exigências da norma, apontar quais os mais adequados ao clima da cidade. A seguir, entre os tipos de alvenaria presentes na norma, são apresentados os mais utilizados nas edificações da cidade (figuras 7.14 a 7.18), com seus respectivos valores de Transmitância $(U)$ e Atraso Térmico $(\varphi)$.

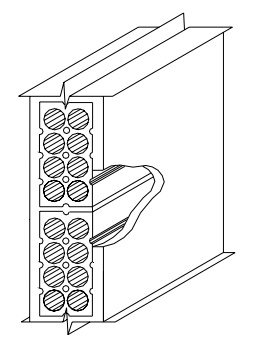

Dimens. tijolo: $10,0 \times 20,0 \times 20,0 \mathrm{~cm}$

Espessura arg. de assent.: $1,0 \mathrm{~cm}$

Espessura arg. de emboço: $2,5 \mathrm{~cm}$

Espessura total da parede: $15,0 \mathrm{~cm}$

$\mathrm{U}=2,24 \mathrm{~W} / \mathrm{m}^{2} \cdot \mathrm{K} / \varphi=3,7$ horas

Figura 7.14 - Parede de tijolos cerâmicos furados assentados na menor dimensão com valores de Transmitância $(U)$ e Atraso Térmico $(\varphi)$. 


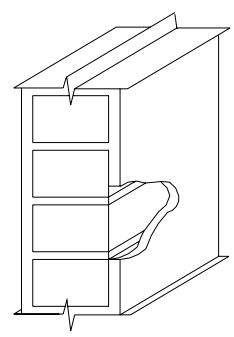

Dimens. tijolo: $10,0 \times 6,0 \times 22,0 \mathrm{~cm}$

Espessura arg. de assent.: $1,0 \mathrm{~cm}$

Espessura arg. de emboço: $2,5 \mathrm{~cm}$

Espessura total da parede: $15,0 \mathrm{~cm}$

$\mathrm{U}=3,13 \mathrm{~W} / \mathrm{m}^{2} . \mathrm{K} / \varphi=3,8$ horas

Figura 7.15 - Parede de tijolos cerâmicos maciços assentados na menor dimensão com valores de Transmitância $(U)$ e Atraso Térmico $(\varphi)$.

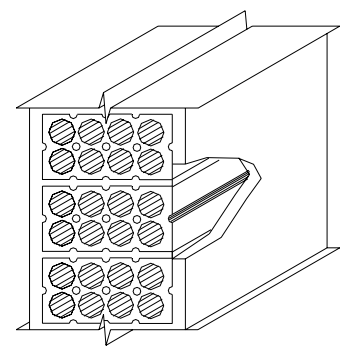

Dimens. tijolo: $10,0 \times 20,0 \times 20,0 \mathrm{~cm}$

Espessura arg. de assent.: $1,0 \mathrm{~cm}$

Espessura arg. de emboço: $2,5 \mathrm{~cm}$

Espessura total da parede: $25,0 \mathrm{~cm}$

$\mathrm{U}=1,61 \mathrm{~W} / \mathrm{m}^{2} . \mathrm{K} / \varphi=5,9$ horas

Figura 7.16 - Parede de tijolos cerâmicos furados assentados na maior dimensão com valores de Transmitância $(U)$ e Atraso Térmico $(\varphi)$.

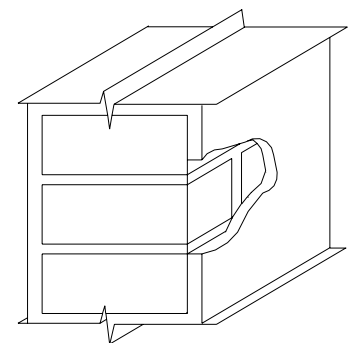

Dimens. tijolo: $10,0 \times 6,0 \times 22,0 \mathrm{~cm}$

Espessura arg. de assent.: $1,0 \mathrm{~cm}$

Espessura arg. de emboço: $2,5 \mathrm{~cm}$

Espessura total da parede: $27,0 \mathrm{~cm}$

$\mathrm{U}=2,25 \mathrm{~W} / \mathrm{m}^{2} . \mathrm{K} / \varphi=6,8$ horas

Figura 7.17 - Parede de tijolos cerâmicos maciços assentados na maior dimensão com valores de Transmitância $(U)$ e Atraso Térmico $(\varphi)$.

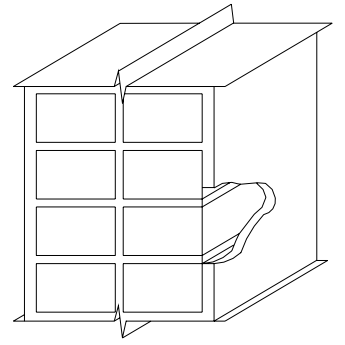

Dimens. tijolo: $10,0 \times 6,0 \times 22,0 \mathrm{~cm}$

Espessura arg. de assent.: $1,0 \mathrm{~cm}$

Espessura arg. de emboço: $2,5 \mathrm{~cm}$

Espessura total da parede: $26,0 \mathrm{~cm}$

$\mathrm{U}=2,30 \mathrm{~W} / \mathrm{m}^{2} . \mathrm{K} / \varphi=6,6$ horas

Figura 7.18 - Parede dupla de tijolos cerâmicos maciços assentados na menor dimensão com valores de Transmitância $(U)$ e Atraso Térmico $(\varphi)$. 
Diante dos exemplos acima e de acordo com as recomendações da norma para o clima de Ribeirão Preto, pode-se afirmar que:

- dentre as alvenarias com tijolos cerâmicos assentados na menor dimensão, a de tijolos furados é mais favorável ao conforto térmico que a de tijolos maciços.

- dentre as alvenarias com tijolos cerâmicos assentados na maior dimensão, a de tijolos furados é mais favorável ao conforto térmico que a de tijolos maciços.

- dentre as alvenarias duplas com tijolos cerâmicos assentados na menor dimensão, a de tijolos furados é mais favorável ao conforto térmico que a de tijolos maciços.

Diante das opções de alvenarias com tijolos cerâmicos furados, pode-se afirmar que:

- a tipologia com tijolos assentados na menor dimensão é a menos favorável ao conforto térmico segundo as recomendações da norma.

- a tipologia dupla com tijolos assentados na menor dimensão é a mais favorável ao conforto térmico segundo as recomendações da norma.

- a tipologia com tijolos assentados na maior dimensão pode configurar uma boa relação custo-benefício em relação ao conforto térmico.

Quanto à cobertura, a norma recomenda serem leves e isoladas, com Transmitância Térmica $U \leq 2,00 \mathrm{~W} / \mathrm{m}^{2}$.K para fluxo descendente , Atraso Térmico $\varphi \leq 3,3$ horas e Fator de Calor Solar FCS $\leq 6,5 \%$. De acordo com a tabela de absortância B.2 da norma, qualquer valor de absortância é válido para que se atenda aos limites da recomendação. A seguir, entre os tipos de cobertura presentes na norma, são apresentados os mais utilizados em Ribeirão Preto (figuras 7.19 a 7.24) com seus respectivos valores de Transmitância $(U)$ e Atraso Térmico $(\varphi)$. 


Espessura da telha: $1,0 \mathrm{~cm}$
Espessura da madeira: $1,0 \mathrm{~cm}$
$\mathrm{U}=2,0 \mathrm{~W} / \mathrm{m}^{2} \cdot \mathrm{K} / \varphi=1,3$ horas

Figura 7.19 - Cobertura de telha cerâmica com forro de madeira com valores de Transmitância (U) e Atraso Térmico $(\varphi)$.

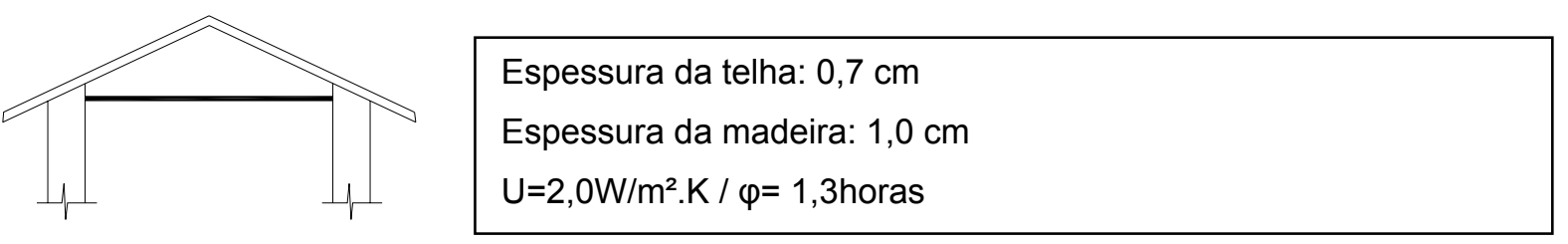

Figura 7.20 - Cobertura de telha de fibro-cimento com forro de madeira com valores de Transmitância $(U)$ e Atraso Térmico $(\varphi)$.

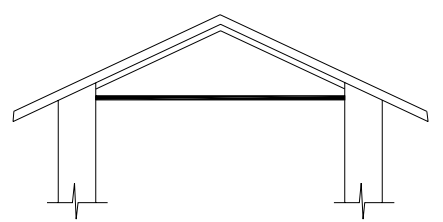

Espessura da telha: $1,0 \mathrm{~cm}$

Espessura da madeira: $1,0 \mathrm{~cm}$

$\mathrm{U}=1,11 \mathrm{~W} / \mathrm{m}^{2} . \mathrm{K} / \varphi=2,0$ horas

Figura 7.21 - Cobertura de telha cerâmica com lamina de alumínio polido e forro de madeira com valores de Transmitância (U) e Atraso Térmico $(\varphi)$.

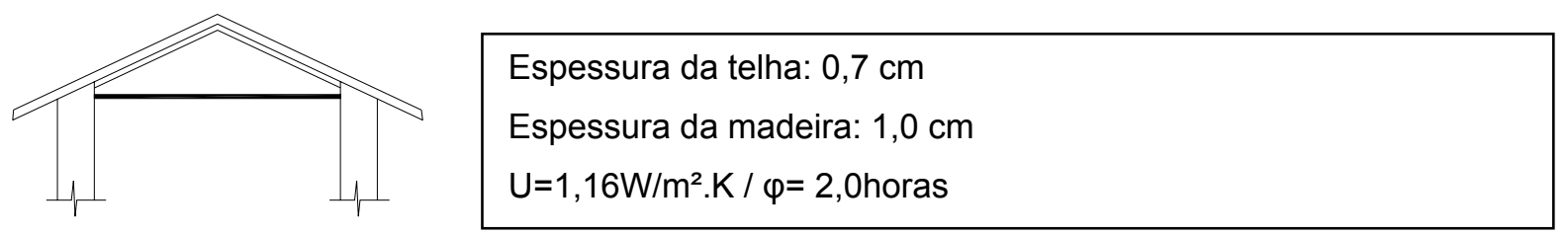

Figura 7.22 - Cobertura de telha de fibro-cimento com lamina de alumínio polido e forro de madeira com valores de Transmitância $(U)$ e Atraso Térmico $(\varphi)$.

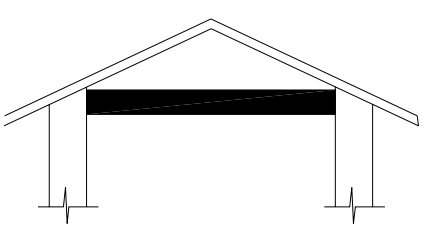

Espessura da telha: $1,0 \mathrm{~cm}$

Espessura da laje: $12,0 \mathrm{~cm}$

$\mathrm{U}=1,92 \mathrm{~W} / \mathrm{m}^{2} . \mathrm{K} / \varphi=3,6$ horas

Figura 7.23 - Cobertura de telha cerâmica com forro em laje mista com valores de Transmitância (U) e Atraso Térmico $(\varphi)$. 


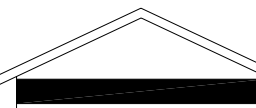

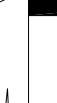
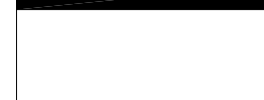

Espessura da telha: $0,7 \mathrm{~cm}$

Espessura da laje: $12,0 \mathrm{~cm}$

$\mathrm{U}=1,93 \mathrm{~W} / \mathrm{m}^{2} . \mathrm{K} / \varphi=3,6$ horas

Figura 7.24 - Cobertura de telha de fibro-cimento com forro em laje mista com valores de Transmitância $(U)$ e Atraso Térmico $(\varphi)$.

Diante dos exemplos acima e de acordo com as recomendações da norma para o clima de Ribeirão Preto, pode-se afirmar que:

- com a utilização de forros em madeira ou laje mista, a sensação térmica em ambientes com telhas de fibro-cimento ou cerâmicas são muito semelhantes.

- a utilização de lâminas de alumínio polido diminuem a Transmitância Térmica e aumentam o Atraso Térmico, o que pode ser considerado favorável ao conforto em locais com grande amplitude térmica como Ribeirão Preto.

- comparando a utilização de forro de madeira com forro de laje mista, os valores de Transmitância Térmica são muito semelhantes, mas com a presença da laje, o Atraso Térmico é bem maior.

A norma ainda salienta que apesar da semelhança entre a transmitância da cobertura de barro e a de fibro-cimento, o desempenho térmico proporcionado pelas duas é diferente. As telhas cerâmicas são porosas e permitem a absorção de água, o que contribui para a redução do fluxo de calor para o interior da edificação através da evaporação. Porém, pelo mesmo motivo, as telhas cerâmicas tendem a escurecer com o tempo, aumentando a absorção de radiação e prejudicando o seu desempenho térmico.

Não constam na norma outras tipologias de cobertura muito utilizadas na cidade como lajes impermeabilizadas e telhas metálicas. Assim, para complementar as recomendações finais deste trabalho, serão consideradas as pesquisas sobre outros sistemas de cobertura presentes no capítulo 5.5 deste trabalho.

Em relação às aberturas, a norma recomenda que estas sejam sombreadas e com áreas entre $15 \%$ a $25 \%$ da área do piso. Estas dimensões se referem à área efetiva 
de ventilação, a qual, dependendo do tipo de abertura, pode não coincidir com a área total do caixilho.

A norma também especifica estratégias de condicionamento térmico passivo para Zona Bioclimática 4:

- No verão:

o resfriamento evaporativo, através do uso de vegetação, fontes de água ou outros recursos que permitam a evaporação de água no ambiente, amenizando a sensação térmica através da perda de calor por evaporação

o uso de paredes internas e externas com maior massa térmica, fazendo com que o calor armazenado durante o dia seja devolvido ao exterior à noite

o ventilação cruzada seletiva nos períodos quentes em que a temperatura externa seja inferior à interna.

o para propiciar a ventilação cruzada deve-se atentar aos ventos predominantes e ao entorno; nos ambientes que tiverem apenas uma abertura para o exterior, manter a porta aberta para que se crie um fluxo de ar.

- No inverno:

o aquecimento solar da edificação através do aproveitamento da radiação solar

o adoção de paredes internas pesadas para manter o interior da edificação aquecido

Para Ribeirão Preto, as recomendações de verão são pertinentes, mas as recomendações de inverno poderiam ser dispensadas em função da pouca representatividade do período frio no ano e também por serem conflitantes com as de verão. O aproveitamento da radiação para aquecimento da edificação no inverno e a utilização de paredes internas pesadas poderia contribuir para o aquecimento desta no verão. 


\subsection{APLICAÇÃO DO MÉTODO DE MAHONEY}

A seguir, é aplicado o método para a cidade de Ribeirão Preto (planilhas 1 e 2). Os procedimentos de preenchimento das planilhas estão detalhados no ANEXO B. 


\begin{tabular}{|l|l|}
\hline LOCALIZAÇÃO & RIBEIRÃO PRETO \\
\hline LONGITUDE & $21^{\circ} 13^{\prime}$ \\
\hline LATITUDE & $47^{\circ} 5^{\prime}$ \\
\hline ALTITUDE & $562 \mathrm{~m}$ \\
\hline
\end{tabular}

TABELA 1 - DADOS CLIMÁTICOS

\begin{tabular}{|c|c|c|c|c|c|c|c|c|c|c|c|c|}
\hline TEMPERATURA DO AR ( $\left.{ }^{\circ} \mathrm{C}\right)$ & $\mathrm{J}$ & $\mathrm{F}$ & $\mathrm{M}$ & A & M & $\mathrm{J}$ & $\mathrm{J}$ & $\mathrm{A}$ & $\mathrm{s}$ & $\mathrm{O}$ & $\mathrm{N}$ & $\mathrm{D}$ \\
\hline MEDIA MENSAL MÁXIMA & 30,0 & 30,5 & 30,0 & 29,0 & 27,0 & 26,0 & 26,5 & 29,0 & 30,5 & 30,5 & 30,0 & 29,5 \\
\hline MEDIA MENSAL MÍNIMA & 18,5 & 18,5 & 18,0 & 16,0 & 13,5 & 12,0 & 12,0 & 13,5 & 15,5 & 17,0 & 17,5 & 18,5 \\
\hline AMPLITUDE MEDIA MENSAL & 11,5 & 12,0 & 12,0 & 13,0 & 14,0 & 14,0 & 14,5 & 15,5 & 15,0 & 13,5 & 12,5 & 11,0 \\
\hline UMIDADE RELATIVA (\%) & 80,5 & 81,1 & 80,2 & 73,2 & 74,4 & 70,5 & 64,9 & 57,1 & 62,2 & 68,4 & 73,6 & 80,3 \\
\hline PRECIPITAÇÃO (mm) & 260,2 & 217,7 & 163,4 & 82,8 & 60,4 & 31,8 & 24,4 & 25,7 & 57,1 & 136,9 & 173,1 & 285,9 \\
\hline VENTOS PREDOMINANTES & NW & SE & $\mathrm{SE}$ & SE & SE & SE & SE & SE & $\mathrm{SE}$ & SE & SE & SE \\
\hline
\end{tabular}

TABELA2-DIAGNÓSTICO

\begin{tabular}{|c|c|c|c|c|c|c|c|c|c|c|c|c|c|}
\hline & & & & & & & & & & & & \\
\hline & & $\mathrm{J}$ & $\mathrm{F}$ & $M$ & A & M & $\mathrm{J}$ & $\mathrm{J}$ & A & $\mathrm{s}$ & $\mathrm{O}$ & $\mathrm{N}$ & $\mathrm{D}$ \\
\hline \multicolumn{2}{|c|}{ GRUPO DE UMIDADE } & 4 & 4 & 4 & 4 & 4 & 4 & 3 & 3 & 3 & 3 & 4 & 4 \\
\hline \multicolumn{2}{|c|}{ MEDIA DAS MÁXIMAS } & 30,0 & 30,5 & 30,0 & 29,0 & 27,0 & 26,0 & 26,5 & 29,0 & 30,5 & 30,5 & 30,0 & 29,5 \\
\hline \multicolumn{2}{|c|}{ LIMITE SUPERIOR DIURNO: } & 27,0 & 27,0 & 27,0 & 27,0 & 27,0 & 27,0 & 29,0 & 29,0 & 29,0 & 29,0 & 27,0 & 27,0 \\
\hline \multicolumn{2}{|c|}{ LIMITE INFERIOR DIURNO: } & 22,0 & 22,0 & 22,0 & 22,0 & 22,0 & 22,0 & 23,0 & 23,0 & 23,0 & 23,0 & 22,0 & 22,0 \\
\hline \multicolumn{2}{|c|}{ MEDIA DAS MINIMAS } & 18,5 & 18,5 & 18,0 & 16,0 & 13,5 & 12,0 & 12,0 & 13,5 & 15, & 17,0 & 17,5 & 18,5 \\
\hline \multicolumn{2}{|c|}{ LIMITE SUPERIOR NOTURNO } & 21,0 & 21,0 & 21,0 & 21,0 & 21,0 & 21,0 & 23,0 & 23,0 & 23,0 & 23,0 & 21,0 & 21,0 \\
\hline \multicolumn{2}{|c|}{ LIMITE INFERIOR NOTURNO: } & 17,0 & 17,0 & 17,0 & 17,0 & 17,0 & 17,0 & 17,0 & 17,0 & 17,0 & 17,0 & 17,0 & 17,0 \\
\hline \multirow[t]{2}{*}{ DIAGNÓSTICO } & DIA & $\mathrm{Q}$ & $\mathrm{Q}$ & $\mathrm{Q}$ & $\mathrm{Q}$ & $\mathrm{Q}$ & $\mathrm{C}$ & C & $\mathrm{Q}$ & $\mathrm{Q}$ & $\mathrm{Q}$ & $\mathrm{Q}$ & $\mathrm{Q}$ \\
\hline & NOITE & C & $\mathrm{C}$ & $\mathrm{C}$ & $\mathrm{F}$ & $\mathrm{F}$ & $\mathrm{F}$ & $\mathrm{F}$ & $\mathrm{F}$ & $\mathrm{F}$ & C & $\mathrm{C}$ & C \\
\hline
\end{tabular}

TABELA 3 - INDICADORES

\begin{tabular}{|c|c|c|c|c|c|}
\hline \multicolumn{3}{|c|}{ INDICADORES } & $\mathrm{J}$ & $\mathrm{F}$ & $M$ \\
\hline \multirow{3}{*}{\multicolumn{2}{|c|}{ UMIDADE: }} & U1 & $x$ & $\bar{x}$ & $x$ \\
\hline & & $\mathrm{U} 2$ & & & \\
\hline & & U3 & $\bar{x}$ & $\bar{x}$ & \\
\hline \multirow{3}{*}{\multicolumn{2}{|c|}{ ARIDEZ: }} & A1 & & & \\
\hline & & $\mathrm{A} 2$ & & & \\
\hline & & A3 & & & \\
\hline \multicolumn{6}{|c|}{ TABELAS 4 - PARÂMETROS DO MÉTODO } \\
\hline \multicolumn{6}{|c|}{ INDICADORES } \\
\hline INDIC. & DIA & NOITE & CHUVA & G. UMID. & AMM \\
\hline \multirow[t]{2}{*}{ U1 } & $\mathrm{Q}$ & & & 4 & \\
\hline & $\mathrm{Q}$ & & & 2,3 & $<10^{\circ} \mathrm{C}$ \\
\hline $\mathrm{U} 2$ & $\mathrm{C}$ & & & 4 & \\
\hline U3 & & & $>200 \mathrm{~mm}$ & & \\
\hline A1 & & & & $1,2,3$ & $>10^{\circ} \mathrm{C}$ \\
\hline \multirow[t]{2}{*}{ A2 } & & $\mathrm{Q}$ & & 1,2 & \\
\hline & $\mathrm{Q}$ & $\mathrm{C}$ & & 1,2 & $>10^{\circ} \mathrm{C}$ \\
\hline A3 & $\mathrm{F}$ & & & & \\
\hline
\end{tabular}

\begin{tabular}{l|c|c|c|c|c|c|c|c|}
\hline A & M & J & J & A & S & O & N & D \\
\hline X & X & & & & & & X & X \\
\hline & & X & & & & & & \\
\hline & & & $\mathrm{X}$ & $\mathrm{X}$ & $\mathrm{X}$ & $\mathrm{X}$ & & $\mathrm{X}$ \\
\hline & & & & & & & & \\
\hline
\end{tabular}

TABELAS 4 - PARÂMETROS DO MÉTODO

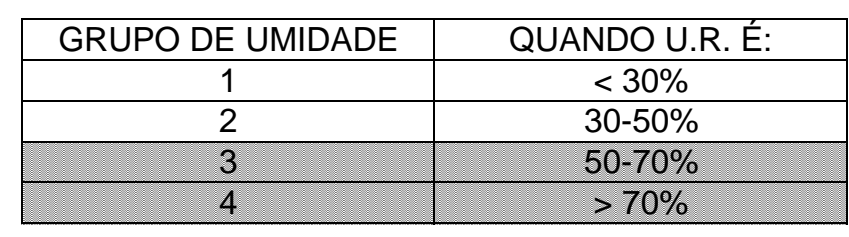

\begin{tabular}{|c|c|c|c|c|c|c|}
\hline \multicolumn{7}{|c|}{ LIMITES DE CONFORTO } \\
\hline G. UMID. & TMA > & ${ }^{\circ} \mathrm{C}$ & TMA 15 & $20^{\circ} \mathrm{C}$ & TMA $<1$ & \\
\hline REL. & DIA & NOITE & DIA & NOITE & DIA & NOITE \\
\hline 1 & $26-34$ & $17-25$ & $23-32$ & $14-23$ & $21-30$ & $12-21$ \\
\hline 2 & $25-31$ & $17-24$ & $22-30$ & $14-22$ & $20-27$ & $12-20$ \\
\hline 3 & $23-29$ & $17-23$ & $21-28$ & $14-21$ & $19-26$ & $12-19$ \\
\hline 4 & $22-27$ & $17-21$ & $20-25$ & $14-20$ & $18-24$ & $12-18$ \\
\hline
\end{tabular}



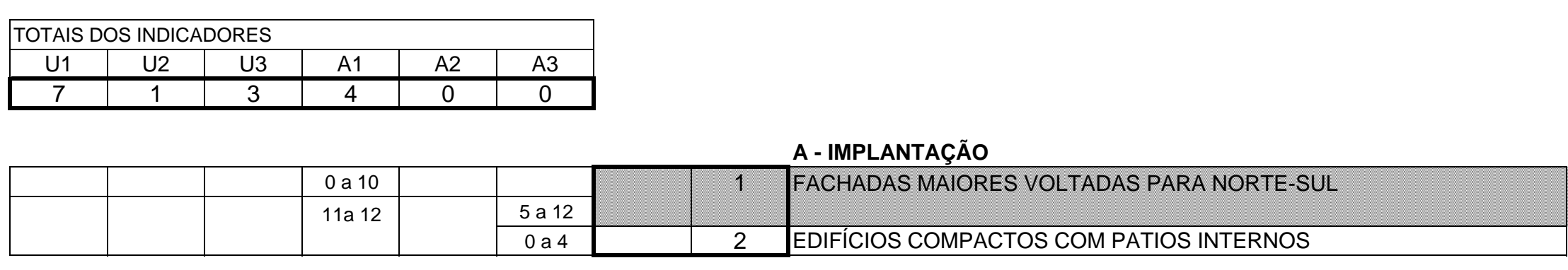

B - ESPAÇAMENTO ENTRE EDIFICAÇÕES

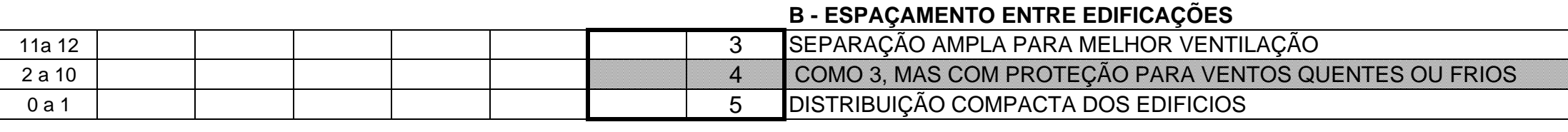

\section{C - VENTILAÇ̃̃O}

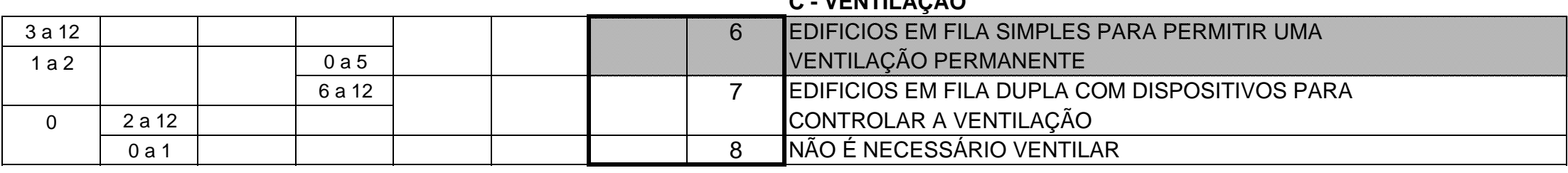

\section{D - TAMANHO DAS ABERTURAS}

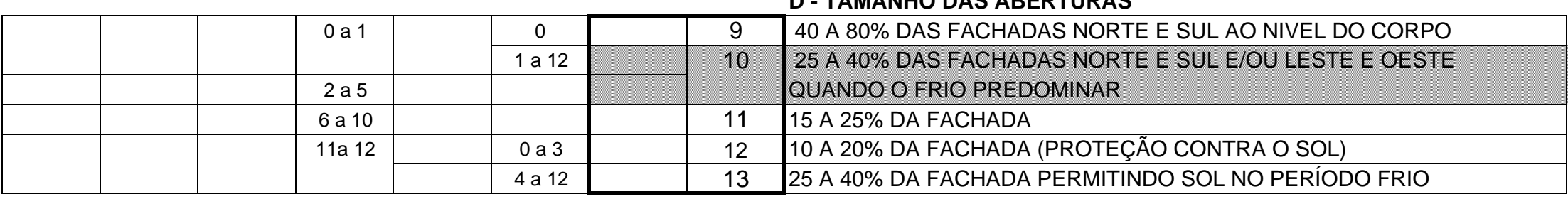

E - POSIÇÃO DAS ABERTURAS

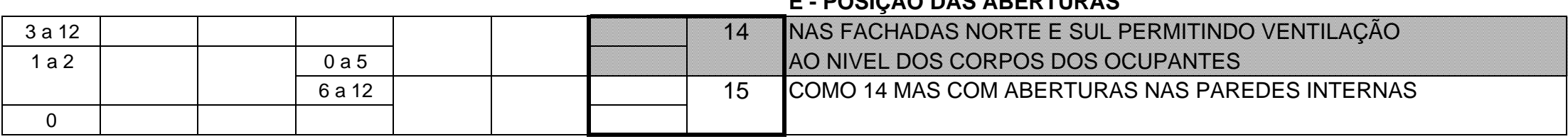

F - PROTEÇÃO ABERTURAS

\begin{tabular}{|l|l|l|l|l|l|l|l|}
\hline & & & & 0 a 2 & & 16 & EVITAR LUZ SOLAR DIRETA NOS INTERIORES \\
\hline & 2 a 12 & & & & & 17 & PROTEGER DA CHUVA PERMITINDO VENTIIAC̃̃O \\
\hline
\end{tabular}

G - PAREDES E PISOS

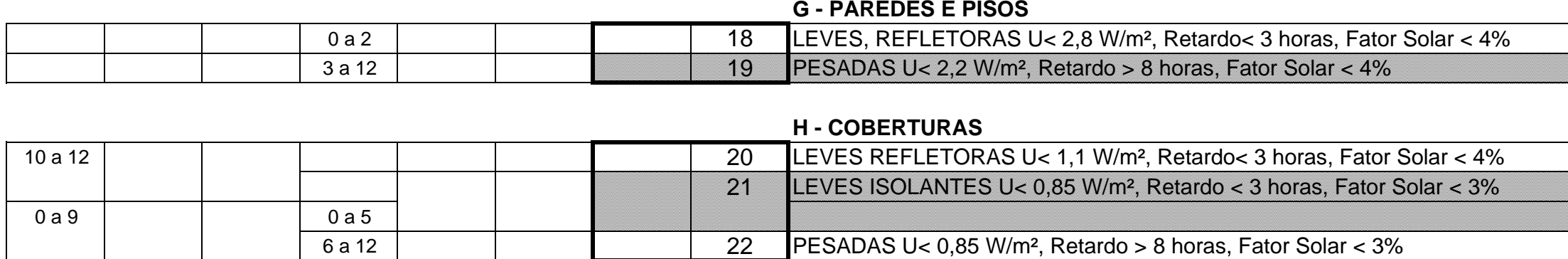

I - EXTERIOR DA EDIFICAÇÃO

\begin{tabular}{|l|l|l|l|l|l|l|l|}
\hline & & & & 1 a 12 & & 23 & ESPAÇO PARA DORMIR AO AR LIVRE \\
\hline & 1 a 12 & & & & & 24 & PROTEGER CONTRA AS CHUVAS
\end{tabular}

Planilha 6.2 - Tabela 5 do Método de Mahoney 
$\mathrm{Na}$ planilha 1, de acordo com os limites de conforto da tabela 4, a tabela 2 aponta que o período diurno é considerado quente para todos os meses com exceção dos meses de junho e julho. As recomendações obtidas na planilha 2 serão a seguir detalhadas de acordo com Roriz (2001):

- Implantação:

o edificações alongadas com fachadas maiores voltadas para Norte e Sul, podendo haver ligeira variação para captação dos ventos dominantes.

- Espaçamentos entre edificações:

o separação ampla entre edificações que permita a ventilação, mas com proteções para ventos quentes e/ou carregados de poeira, no coso dos meses quentes e secos.

- Ventilação:

o deve-se otimizar a ventilação cruzada, sendo preferível que as habitações ou seus ambientes sejam dispostos em fila simples, com as circulações abertas para o exterior.

- Tamanho das aberturas:

o as aberturas devem ter área de 25 a $40 \%$ da fachada

- Posição das aberturas:

o as aberturas devem estar dispostas nas fachadas Norte e Sul e permitirem ventilação ao nível dos corpos. Para otimizar a velocidade do ar, as aberturas de saída devem ser maiores e mais altas que as de entrada.

- Proteção das aberturas:

o as aberturas devem contar com proteções que evitem a penetração da radiação solar direta nos ambientes internos, protejam das chuvas e ao mesmo tempo permitam ventilação. 
- Paredes e pisos:

o paredes pesadas com alta inércia térmica sendo, Transmitância Térmica $U \leq 2,20 \mathrm{~W} / \mathrm{m}^{2}$.K , Atraso Térmico $\varphi \geq 8$ horas e Fator de Calor Solar FCS $\leq 4 \%$. As superfícies externas devem ser em cores claras.

- Coberturas:

o coberturas leves e isoladas com alta inércia térmica sendo, Transmitância Térmica $U \leq 0,85 \mathrm{~W} / \mathrm{m}^{2} . \mathrm{K}$, Atraso Térmico $\varphi \geq 3$ horas e Fator de Calor Solar FCS $\leq 3 \%$.

- Exterior da edificação:

o proteger contra as chuvas nos meses com pluviosidade acima de 200mm, evitando erosão ao redor da superfície e deterioração dos revestimentos exteriores.

\subsection{DISCUSSÃO}

Através de quadro comparativo abaixo (tabela 6.33), são confrontados os resultados obtidos com a aplicação dos dois métodos com as conclusões sobre as particularidades do clima em Ribeirão Preto. O quadro considera as recomendações obtidas para cada aspecto da edificação assim como a importância e necessidades de complementação e adaptação para o clima local. A partir dele, será apresentado no próximo capítulo o conjunto final de recomendações de projeto para a cidade de Ribeirão Preto. 
Tabela 7.34 Comparativo entre recomendações da NBR15220 e Método de Mahoney para Ribeirão Preto.

\begin{tabular}{|c|c|c|c|}
\hline ASPECTOS & $\begin{array}{c}\text { RECOMENDAÇÃO } \\
\text { NBR } 15220\end{array}$ & $\begin{array}{c}\text { RECOMENDAÇÃO } \\
\text { MAHONEY }\end{array}$ & $\begin{array}{c}\text { FATORES LOCAIS I } \\
\text { OBSERVAÇÕES }\end{array}$ \\
\hline Implantação & $\mathrm{X}$ & $\begin{array}{c}\text { Edifícios alongados e } \\
\text { espaçamento, permitindo } \\
\text { ventilação entre edificios }\end{array}$ & $\begin{array}{c}\text { Menor área possível } \\
\text { exposta à radiação direta }\end{array}$ \\
\hline Orientação & $x$ & $\begin{array}{c}\text { Fachadas maiores } \\
\text { voltadas para Norte e Sul }\end{array}$ & $\begin{array}{l}\text { Pode-se utilizar também } \\
\text { a classificação de } \\
\text { orientações, prevendo } \\
\text { proteções solares }\end{array}$ \\
\hline $\begin{array}{l}\text { Aberturas - } \\
\text { tamanho }\end{array}$ & $\begin{array}{c}15 \% \text { a } 25 \% \text { da área de } \\
\text { piso }\end{array}$ & $\begin{array}{c}25 \% \text { a } 40 \% \text { da área de } \\
\text { fachada }\end{array}$ & $\begin{array}{c}\text { Considerar a área efetiva } \\
\text { de abertura do caixilho; a } \\
\text { relação com a área de } \\
\text { piso é mais aceitável pois } \\
\text { já está na legislação }\end{array}$ \\
\hline $\begin{array}{c}\text { Aberturas - } \\
\text { posição }\end{array}$ & $x$ & $\begin{array}{l}\text { Nas fachadas Norte e Sul } \\
\text { estando a de saída mais } \\
\text { alta que a de entrada }\end{array}$ & $\begin{array}{c}\text { Pode-se orientar de } \\
\text { acordo com a } \\
\text { classificação de } \\
\text { orientações prevendo } \\
\text { proteções solares; } \\
\text { observar a incidência dos } \\
\text { ventos na edificação para } \\
\text { o posicionamento da } \\
\text { aberturas de entrada e } \\
\text { saída }\end{array}$ \\
\hline $\begin{array}{l}\text { Aberturas - } \\
\text { proteções }\end{array}$ & Sombreadas & $\begin{array}{l}\text { Protegidas da radiação } \\
\text { direta }\end{array}$ & $\begin{array}{c}\text { Observar os tipos de } \\
\text { proteção adequados para } \\
\text { cada orientação }\end{array}$ \\
\hline Paredes & Pesadas, cores claras & Pesadas, cores claras & $\begin{array}{c}\text { Em edificações altas as } \\
\text { paredes são o } \\
\text { componente de grande } \\
\text { absorção de calor. A } \\
\text { relevância da cor pode } \\
\text { ser maior que a do } \\
\text { material na absorção de } \\
\text { calor }\end{array}$ \\
\hline
\end{tabular}




\begin{tabular}{|c|c|c|c|}
\hline Cobertura & Leves e isoladas & Leves e isoladas & $\begin{array}{l}\text { Em edificações térreas a } \\
\text { cobertura é o } \\
\text { componente de grande } \\
\text { absorção de calor. } \\
\text { Necessidade de mais } \\
\text { alternativas de cobertura } \\
\text { além das que estão na } \\
\text { norma. A relevância da } \\
\text { cor pode ser maior que a } \\
\text { do material na absorção } \\
\text { de calor }\end{array}$ \\
\hline Entorno & $x$ & Proteção contra chuvas & $\begin{array}{l}\text { O entorno influencia no } \\
\text { aquecimento da } \\
\text { edificação e do seu } \\
\text { microclima ; tratá-lo com } \\
\text { vegetação de maneira a } \\
\text { minimizar a reemissão de } \\
\text { radiação em ondas } \\
\text { longas }\end{array}$ \\
\hline $\begin{array}{c}\text { Estratégias } \\
\text { de verão }\end{array}$ & $\begin{array}{c}\text { Resfriamento evaporativo } \\
\text { e ventilação cruzada }\end{array}$ & Ventilação cruzada & $\begin{array}{c}\text { Proteção à radiação } \\
\text { como principal estratégia }\end{array}$ \\
\hline $\begin{array}{l}\text { Estratégias } \\
\text { de inverno }\end{array}$ & $\begin{array}{c}\text { Aquecimento solar / } \\
\text { paredes internas pesadas }\end{array}$ & $X$ & $\begin{array}{c}\text { Dispensável devido à } \\
\text { pouca relevância do } \\
\text { período frio na cidade e à } \\
\text { conflitância com as } \\
\text { estratégias de verão. }\end{array}$ \\
\hline
\end{tabular}




\section{RECOMENDAÇÕES DE PROJETO}

O clima de Ribeirão Preto, composto por um período quente e úmido e outro quente e seco, requer maior cuidado na geração de recomendações para que se alcance um conforto térmico satisfatório nas edificações durante todo o período quente. Considerando a revisão bibliográfica e os resultados obtidos no capítulo anterior, reúnem-se aqui recomendações de projeto sobre diversos aspectos construtivos que podem propiciar melhor desempenho térmico nas edificações da cidade.

\subsection{IMPLANTAÇÃO, DISTRIBUIÇÃO E FORMA DO EDIFÍCIO}

As edificações devem ser alongadas e bem espaçadas entre si com amplos recuos, que permitam boa ventilação entre estas. A forma dos edifícios deve minimizar áreas de vedações externas expostas à radiação direta.

Indica-se a setorização do programa, de maneira a dispor os ambientes de baixa permanência nas áreas mais críticas, e os ambientes de longa permanência em áreas mais privilegiadas, com menor incidência solar, boas condições de ventilação e próximas a áreas sombreadas e com vegetação.

Um elemento favorável às edificações na cidade é a utilização de pátios internos, sombreados, com vegetação e se possível com presença de água. Os pátios podem configurar vedações externas com aberturas não expostas à radiação direta e através de conexões com os ambientes internos, podem proporcionar a circulação de ar com melhores condições de temperatura e umidade do que o ar externo. 


\subsection{ORIENTAÇÃO}

De maneira geral, as fachadas com maior extensão devem estar voltadas para Norte e Sul. Indica-se esta orientação pois a fachada Sul é uma das que menos recebe incidência solar e fachada Norte não recebe incidência solar no verão. Nas outras estações do ano, quando ocorre incidência solar, as proteções solares são simples de serem projetadas devido aos ângulos de incidência solar nesta orientação. Porém, pode-se adotar outras orientações desde se preveja proteções solares e sombreamento para as fachadas sujeitas a uma incidência de radiação direta indesejável.

Duas importantes ferramentas foram desenvolvidas durante este trabalho: o traçado solar para oito orientações na latitude de Ribeirão Preto e a classificação de fachadas segundo o ganho de calor por radiação no período da tarde. Ambas encontram-se detalhadas no capítulo 7 deste trabalho. Estas ferramentas podem auxiliar na tomada de decisões em relação à implantação de edificações e na orientação de seus ambientes internos no sentido de minimizar sobreaquecimento decorrente da incidência de radiação direta em ambientes onde este fator seja indesejável. Cabe ressaltar que em alguns ambientes como dormitórios, apesar da questão do aquecimento, a incidência de radiação solar é desejável por questões de salubridade devido à ação bactericida dos raios ultra-violeta. Nem sempre é possível dispor os ambientes para as orientações mais favoráveis. Assim, para se pensar a implantação deve-se ponderar com bom senso a incidência ou não de radiação solar em cada ambiente da edificação.

A orientação da edificação deve também levar em conta a ocupação dos ambientes internos. Ambientes de baixa permanência, como circulações, banheiros, depósitos, garagens podem estar dispostos em fachadas mais críticas. Já os ambientes de maior permanência e convívio seriam dispostos nas fachadas com menor incidência solar. Outra maneira é considerar os horários de ocupação de cada ambiente e relacioná-los com os horários de incidência solar de cada fachada, evitando que, 
durante a sua utilização, o ambiente esteja aquecido em demasia pela radiação direta.

\subsection{ABERTURAS}

\subsubsection{Orientação}

As aberturas devem ser dispostas nas fachadas levando-se em conta dois aspectos: a insolação e a ventilação. Em relação à insolação, deve-se orientar as aberturas de maneira a evitar a penetração de insolação nos ambientes internos, principalmente no período da tarde. No caso de necessidade em dispor aberturas em fachadas desfavoráveis, devem ser previstas proteções externas que reduzam a incidência solar sem prejudicar a ventilação (item 8.6.1). Em relação à ventilação, deve-se orientar as aberturas de acordo com a incidência dos ventos na edificação, para um correto posicionamento das aberturas de entrada e saída. Para isto, não basta conhecer a direção predominante do vento. Cabe ao projetista detectar no local, possíveis elementos como edificações próximas, árvores, acidentes topográficos, que afetem a direção e velocidade dos ventos que atingirão o edifício. Nem sempre é necessário que as aberturas estejam posicionadas perpendicularmente à incidência dos ventos. Pode-se aproveitar a penetração dos ventos mesmo quando estes incidem obliquamente às aberturas de entrada.

Em Ribeirão Preto, há um fator favorável ao posicionamento de aberturas, que facilita a consideração concomitante da questão da insolação e dos ventos dominantes. As fachadas mais favoráveis do ponto de vista da ventilação, como a Leste, Sudeste e Sul, são também as mais favoráveis do ponto de vista da insolação. Porém, cabe ressaltar que devido à topografia da cidade, as áreas situadas na periferia do município contam com melhores condições de ventilação. 


\subsubsection{Dimensionamento e ventilação}

O dimensionamento das aberturas deve ser de $15 \%$ a $25 \%$ da área de piso. Deve se atentar para o tipo de abertura do caixilho, levando-se em conta o tamanho de abertura efetiva, e não o seu tamanho total. Como exemplo, num caixilho com duas folhas, uma fixa e outra de correr, a área efetiva de ventilação será no máximo a metade de sua área total. Devido à variação das condições de umidade e temperatura no período quente, a ventilação pode ou não ser favorável ao conforto. Portanto, é desejável que o sistema de abertura dos caixilhos seja flexível, evitando a penetração de ventos quentes no período seco.

Para o efeito de ventilação cruzada, devem ser previstas ao menos duas aberturas no ambiente, para que uma funcione como entrada e outra como saída. Devem ser posicionadas em paredes distintas, de maneira que o percurso do ar entre uma abertura e outra percorra o máximo de área do ambiente. Já para o efeito chaminé, é necessária uma diferença significativa de altura entre as aberturas de entrada e saída, sendo que quanto maior a diferença, mais eficiente é a circulação do ar. Os dois efeitos podem se dar de maneira conjugada com as mesmas aberturas.

A utilização de aberturas próximas ao forro também pode ser uma boa solução para retirada de calor do ambiente, pois evita que o ar quente acumulado no ambiente fique aprisionado próximo ao forro.

\subsection{VEDAÇÕES EXTERNAS}

\subsubsection{Paredes}


No caso de edifícios de múltiplos pavimentos, as paredes são componentes de grande absorção de calor.

Deve-se atentar para a posição das paredes externas de modo que as fachadas de maior extensão recebam menor insolação. Quanto ao material as alvenarias duplas de tijolo cerâmico furado rebocada dos dois lados apresentam ótimo desempenho térmico. Porém esta tipologia pode ser inviável do ponto de vista econômico para muitas edificações. Alvenarias simples de tijolo cerâmico furado, rebocada dos dois lados apresentam desempenho térmico satisfatório, sendo em geral mais favoráveis ao conforto que as alvenarias com tijolos maciços no caso de Ribeirão Preto. As fachadas de uma mesma edificação apresentam conforto térmico distinto em função de sua orientação. Assim, podem ser utilizados materiais diferentes para cada fachada em função de sua orientação e influencia nos ambientes internos. Materiais com ótimo desempenho térmico mas de alto custo podem ser utilizados apenas nas fachadas mais críticas.

A cor da superfície externa das alvenarias é de extrema relevância para as condições de conforto dos ambientes internos, pois influencia significativamente na absorção de calor destas. De maneira geral, quanto mais clara a superfície menor a absorção de calor. Assim, para Ribeirão recomenda-se a utilização de cores claras nas superfícies externas das paredes, principalmente nas fachadas com maior incidência solar.

A previsão de sombreamento através da utilização de vegetação ou proteções solares nas paredes mais expostas à radiação é uma boa estratégia para a redução do ganho de calor pelas paredes.

\subsubsection{Cobertura}


No caso de edificações baixas, a cobertura tem maior relevância que as paredes na absorção de calor pela edificação, devido ao seu posicionamento próximo ao plano horizontal.

Quanto ao material, de maneira geral podem ser utilizadas telhas cerâmicas, de concreto, metálicas ou de fibrocimento. Mas independentemente do material, devem ser de cores claras ou receberem pintura na cor branca ou semelhante. Se houver a presença de ático e forro em laje mista, a influencia do material da telha no conforto do ambiente fica reduzida.

A utilização de lâminas de alumínio entre telhado e forro de madeira ou laje aumenta o atraso térmico do conjunto, retardando o fluxo de calor do exterior para o interior durante o dia e do interior para o exterior durante a noite. Portanto deve-se avaliar se esta propriedade é favorável em função do tipo de ocupação da edificação.

Um sistema de cobertura que tem se mostrado favorável ao conforto térmico em climas quentes é a cobertura verde. A presença de vegetação na cobertura resulta num grande atraso térmico, contribuindo para um menor aquecimento dos ambientes internos. Cabe ressaltar que, para o bom funcionamento deste sistema, deve-se respeitar as especificações técnicas contidas nas pesquisas existentes sobre o assunto assim como prever um sistema fácil de manutenção da vegetação.

Além da utilização de materiais e cores adequadas, alguns recursos podem influenciar positivamente no desempenho térmico das coberturas em Ribeirão Preto. A utilização do ático ventilado permite a circulação de ar no espaço entre forro e cobertura ajuda a reduzir o aquecimento do ambiente durante e auxilia na retirada de calor do ambiente durante a noite. O sombreamento da cobertura principalmente no período da tarde é extremamente favorável ao conforto. Este sombreamento pode se dar através de vegetações de grande porte ou através de sobre-coberturas. 


\subsubsection{Superfícies envidraçadas e transparentes}

As superfícies envidraçadas e transparentes devem ser sombreadas em qualquer orientação onde haja incidência solar direta. Este sombreamento deve se dar a partir de elementos externos, de maneira a minimizar a incidência solar nas superfícies transparentes. As proteções internas não são tão eficientes, pois permitem que os raios solares atravessem a superfície transparente e penetrem no ambiente interno. Ao contrário do que muitos acreditam as películas para vidros não podem ser consideradas como proteções eficientes do ponto de vista térmico. A maioria das películas existentes conseguem barrar uma pequena parcela dos raios infravermelhos, que dentro do espectro solar são os responsáveis pelo calor, e portanto não impedem a entrada de calor através das superfícies envidraçadas.

Apesar de ser muitas vezes prejudicial ao conforto térmico, a utilização de superfícies transparentes em edificações cria ambientes visualmente agradáveis além de atender a necessidades de iluminação. Portanto, recomenda-se que a utilização destas esteja atenta a uma proporção razoável entre áreas opacas e transparentes. A utilização de superfícies transparentes em coberturas não é recomendada para Ribeirão Preto.

\subsection{TRATAMENTO DO ENTORNO}

As superfícies do entorno têm a propriedade de absorver parte da radiação solar e então reemitir ao meio e à edificação na forma de radiação de ondas longas, contribuindo para seu aquecimento durante o dia. Assim, o grau de refletância das superfícies próximas à edificação influencia diretamente no ganho de calor desta, além de influenciar nas temperaturas do micro clima local.

No caso de superfícies com vegetação, a absorção de radiação é alta, mas a reemissão é baixa, se comparada a superfícies pavimentadas (RIVERO, 1985). 
Assim, recomenda-se tratar o entorno da edificação de maneira a manter ou criar o máximo possível de áreas verdes e que estas áreas sejam bem ventiladas, no sentido de minimizar o ganho de calor na edificação e o aumento de temperatura do microclima local. A utilização de vegetação de grande porte para a criação de áreas sombreadas é extremamente favorável.

\subsection{ESTRATÉGIAS DE CONDICIONAMENTO TÉRMICO PASSIVO}

\subsubsection{Proteções à radiação solar}

No caso de Ribeirão Preto, dentre as recomendações e estratégias estudadas, pode-se considerar a proteção à radiação como principal estratégia de condicionamento térmico passivo, pois além de ser favorável durante todo o ano, sua eficiência não é afetada por variações climáticas e elementos externos e internos. A proteção de uma edificação em relação à radiação envolve um conjunto de aspectos. Além dos conceitos já vistos nos itens anteriores, como orientação das fachadas, tratamento da cobertura e tratamento do entorno, podem ser utilizados elementos de proteção para fachadas e aberturas que minimizem a incidência de radiação direta através do sombreamento destes. Cabe ressaltar que as proteções devem ser sempre externas, de maneira a impedir que a radiação atinja as superfícies.

As proteções podem se dar na forma de elementos construtivos já conhecidos como beirais e marquises prolongados, varandas, elementos vazados, empenas e muros, brises, pergolados, entre outros. Mas a possibilidade de proteções é infinita e depende do exercício criativo do projetista, podendo apresentar soluções inusitadas como o caso da residência do item 3.4.2 deste trabalho. 
A utilização da vegetação como proteção solar, através de elementos já existentes no terreno ou do planejamento paisagístico, é extremamente favorável ao conforto térmico. Além de sombrear as superfícies ou aberturas desejadas, sombreia também o entorno da edificação melhorando as condições de seu microclima.

A aplicação dos elementos de proteção solar depende da orientação da superfície a ser protegida. Alguns dependem de métodos geométricos específicos de desenho que não são tratados neste trabalho. Mas, de maneira geral deve-se considerar a altura e os ângulos horizontais de incidência solar na fachada que se pretende proteger, de acordo com os traçados do capítulo 7 deste trabalho. Em fachadas como a Norte, onde a radiação incide com uma altura solar maior, a proteção pode se dar através de simples beiral ou marquise. Já em fachadas onde a altura solar é menor, como a Oeste, as proteções devem estar dispostas como anteparos entre a posição do sol e a superfície, sem que isto impeça a circulação de ar nesta superfície.

\subsubsection{Ventilação}

A ventilação natural é uma importante estratégia de condicionamento térmico passivo quando aliada a certas condições de umidade e temperatura. No caso de Ribeirão Preto, a ventilação natural tem maior contribuição para a redução de temperaturas dos ambientes e melhora na sensação térmica do indivíduo nos meses quentes e úmidos. Já nos meses com baixa umidade relativa, a ventilação natural pode ser desfavorável ao conforto térmico. Devido à baixa umidade e altas temperaturas, frequentemente nesta época os ventos no período da tarde trazem uma temperatura maior do que a dos ambientes internos, além de estarem carregados de poeira. Porém, vale ressaltar que ventilar significa também introduzir no interior do edifício as condições exteriores. Como durante a noite as temperaturas internas geralmente são superiores às externas, mesmo nos meses secos a ventilação teria efeito refrescante, retirando calor do interior no período noturno. 
Deve ainda se considerar que as condições topográficas de Ribeirão Preto prejudicam a incidência dos ventos em algumas partes da sua área urbana. 


\section{CONCLUSÕES}

As recomendações obtidas com a aplicação da NBR15220 e do Método de Mahoney serviram de base científica e contribuíram de maneira satisfatória para o resultado deste trabalho. Porém, a análise das particularidades climáticas de Ribeirão Preto foi de grande relevância, pois possibilitou ponderar e complementar as recomendações obtidas no sentido de originar um conjunto de recomendações de projeto mais adequado e específico para o clima de Ribeirão Preto. Na maioria das vezes, falhas de projeto em relação ao conforto térmico poderiam ser evitadas nas primeiras decisões dentro do processo de projeto. Portanto estas recomendações, ainda que gerais, certamente contribuem para melhores condições de conforto térmico na cidade.

O desenvolvimento do traçado dos ângulos solares para oito orientações durante o período os meses mais quentes possibilitou a compreensão da trajetória solar na latitude de Ribeirão Preto além de facilitar o processo de projeto de proteções solares. A proteção à radiação configurou-se como a principal estratégia de condicionamento passivo para as edificações da cidade. Portanto, o detalhamento dos ângulos solares assume destacada importância neste trabalho.

A contribuição deste conjunto de recomendações de projeto visando o conforto térmico em edificações para Ribeirão Preto não se esgota com a finalização desta pesquisa. Este conjunto deu subsídios à criação de um manual de projeto prático ilustrado que encontra-se como Apêndice neste trabalho. Após a sua revisão, prevista para início de 2009, pretende-se disponibilizar este manual por meios eletrônicos e/ou impressos contando com a divulgação nas associações profissionais e centros universitários da cidade. 


\subsection{SUGESTÕES PARA PESQUISAS FUTURAS}

- pesquisas sobre conforto térmico no ambiente urbano de Ribeirão Preto.

- utilização de outros métodos para a geração de recomendações de projeto mais específicas, voltadas para as fases de detalhamento do projeto.

- estudos quantitativos do comportamento térmico de materiais e sistemas construtivos na cidade. 


\section{REFERÊNCIAS BIBLIOGRÁFICAS}

ACOSTA, L. M. Avaliação do desempenho térmico de edifícios de habitação múltiplos pisos na cidade de Ribeirão Preto. Dissertação de Mestrado. São Carlos: Escola de Engenharia de São Carlos USP, 2002.

AEAARP - Associação de Engenharia, Arquitetura e Agronomia de Ribeirão Preto. Manual do Código de Obras de Ribeirão Preto. Ribeirão Preto, BMV, 1996.

ASHRAE Standard 90.1 -1999. American Society of Heating, Refrigerating and AirConditioning Engineers, Inc. Atlanta, 1999.

ASSOCIACAO BRASILEIRA DE NORMAS TÉCNICAS - ABNT. NBR 15220 Desempenho Térmico de Edificações. Rio de Janeiro: ABNT, 2003.

BLAT, V. Os Padrões de Desempenho do Uso e Ocupação do solo na Previsão de Controle do Adensamento de Áreas Intra-urbanas. Tese de Doutorado, Escola Politécnica da Universidade de São Paulo. São Paulo: 1997.

BOGO, A.; PIETROBON, C. E.; BARBOSA, M. J.; GOULART, S.; PITTA, T.

Bioclimatologia aplicada ao projeto de edificações visando o conforto térmico. Florianópolis: NPC: UFSC, 1994. 
CARAM, R. M.; LABAKI, L. C.; SICHIERI, E. P. Películas para Controle Solar: comparação de desempenho entre as refletivas e as não refletivas. In: V ENCAC Encontro Nacional de Conforto no Ambiente Construído, Fortaleza: 1999.

CARTANA, R.P.; PEREIRA, F.O.R. Limitações e Oportunidades para Bioclimatologia Aplicada aos Projetos Arquitetônicos Desenvolvidos no Mercado da Construção Civil. In: IX Encontro Nacional e V Encontro Latino Americano de Conforto no Ambiente Construído, Ouro Preto: 2007.

CHVATAL, K. M. S. A Prática do Projeto Arquitetônico em Campinas, SP e Diretrizes para o Projeto de Edificações Adequadas ao Clima. Dissertação de mestrado. Faculdade de Engenharia Civil, UNICAMP, Campinas, 1998.

CODERP - Companhia de Desenvolvimento Econômico de Ribeirão Preto. Disponível em: <http://www.ribeiraopreto.sp.gov.br>. Acesso em 21 out. 2007.

CRITCHFIELD, A. T. General Climatology. New York: Prentice Hall, 1960.

DIZERÓ, J.D. Praças no Interior Paulista: estudos de caso nas cidades de Ribeirão Preto e Monte Alto - S.P. Dissertação de mestrado, PUC. Campinas: 2006.

DUARTE, D. H. S. O Clima como Parâmetro de Projeto na Região de Cuiabá. Dissertação de mestrado. Universidade de São Paulo, São Paulo: 1995.

EVANS, J. M. From Meteorological Data to Bioclimatic Design - 30 years of The Mahoney Tables. In: 16th CONFERENCE ON PASSIVE AND LOW ENERGY ARCHITECTURE - PLEA. Brisbane, 1999. 
FROTA, A. B. Geometria da Insolação. São Paulo, Geros, 2004.

GELLER, H. S. Efficient electricity use: a development strategy for Brazil. Washinton D.C : American Council for an Energy-Efficient Economy, 1990.

GIVONI, B. Man, Climate and Architecture. London: Applied Science, 1976

GIVONI, B. (1992). Comfort Climate Analysis and Building Design Guidelines. Energy and Building, 18 (1), 11-23.

GIVONI, B. Passive and Low Energy Cooling of Buildings. New York: Van Nostrand Reinhold, 1994

GOMES, M. A. S. e SOARES, B. R. A Vegetação nos Centros Urbanos:

Considerações Sobre os Espaços Verdes em Cidades Médias Brasileiras. Estudos Geográficos, Rio Claro, 1(1): 19-29, Junho, 2003 UNESP - Universidade Estadual Paulista, Rio Claro, 1999, 125p. Disponível em: <www.rc.unesp.br/igce/grad/geografia/revista.htm>

GONÇALVES, W. B. et al. Estudo de Zoneamento Bioclimático Para o Estado de Minas Gerais com Base nas Tabelas de Mahoney. In: VII Encontro Nacional de Conforto no Ambiente Construído. Curitiba, 2003.

GUZZO, P. Estudo dos Espaços Livres de Uso Publico da Cidade de Ribeirão Preto/SP, com Detalhamento da Cobertura Vegetal e Áreas Verdes de Dois Setores Urbanos. Dissertação de Mestrado UNESP - Universidade Estadual Paulista, Rio Claro: 1999. 
IAC - Instituto Agronômico - Estação Experimental de Ribeirão Preto. Normais Climatológicas 1961 - 1990. Ribeirão Preto, SP.

IBGE - Instituto Brasileiro de Geografia e Estatística. Disponível em: <http://www.ibge.gov.br>. Acesso em 21 out. 2007.

IZARD, J. L.; GUYOT, A. Arquitectura Bioclimática. México D.F.: Gustavo Gilli, 1983.

KOENIGSBERGER, O. H.; INGERSOLL, T. G.; MAYHEW, A.; SZOKOLAY. S. V. Manual of Tropical Housing and Building - Part 1 Climatic Design. Nova Yorque: Longman, 1973.

KOENIGSBERGER, O. H. Viviendas y Edifícios em Zonas Cálidas y Tropicales. Madrid: Paraninfo, 1979.

KONIA, A. Diseño en Climas Cálidos. Madrid: H. Blume Ediciones, 1981.

LAMBERTS, R.; GOULART, S.; CARLO, J.; WESTPHAL, F.; PONTES, R. O. Regulamentação de Etiquetagem Voluntária de Nível de Eficiência Energética de Edifícios Comerciais e Públicos. In: IX Encontro Nacional e V Encontro Latino Americano de Conforto no Ambiente Construído, Ouro Preto: 2007.

MASCARENHAS, A.; NERY, J.F.; D'ALCANTARA, A. Conservação de Energia e Conforto Ambiental em Edificações Comerciais em Salvador. Relatório COELBA/UFBA/PROCEL, 1988. 
MME - Ministério das Minas e Energia. BEN - Balanço Energético Nacional 2007

MACIEL, A. A. Integração de Conceitos Bioclimáticos ao Projeto Arquitetônico. Tese de Doutorado. Florianópolis, Universidade Federal de Santa Catarina: 2006.

MONTERO, J. I. P. Ventilação e Iluminação Naturais na Obra de João Filgueiras Lima, Lelé: estudo dos hospitais da rede Sarah Kubitscheck Fortaleza e Rio de Janeiro. Dissertação de Mestrado. São Carlos: Escola de Engenharia de São Carlos USP, 2006.

MORAIS, C. RORIZ, M. Temperaturas em Protótipo de Edificação com Cobertura Ajardinada: São Carlos, SP. In: VIII Encontro Nacional e IV Encontro Latino Americano de Conforto no Ambiente Construído, Maceió: 2005.

MORISHITA, C.; SCHIMID, A. L. Ventilação Natural por Efeito Chaminé em Sobrados: um estudo do uso desta técnica pelos arquitetos do Paraná. In: IX Encontro Nacional e $\mathrm{V}$ Encontro Latino Americano de Conforto no Ambiente Construído, Ouro Preto: 2007.

NEVES, L. Arquitetura Bioclimática e a Obra de Severiano Porto: Estratégias de Ventilação Natural. Dissertação de Mestrado. São Carlos: Escola de Engenharia de São Carlos USP, 2006.

OLGYAY, Victor. Arquitectura y Clima: manual de diseño bioclimático para arquitetos y urbanistas. Barcelona: Gustavo Gilli, 1998. 
PEDRINI, A. SZOKOLAY, S. Recomendações para o Desenvolvimento de uma Ferramenta de Suporte às Primeiras Decisões Projetuais Visando ao Desempenho Energético de Edificações de Escritório em Clima Quente. In: Ambiente Construído, Porto Alegre: janeiro/março 2005.

PERALTA, G. Desempenho térmico de Telhas: análise de monitoramento e normalização especifica. Dissertação de Mestrado. São Carlos: Escola de Engenharia de São Carlos USP, 2006.

PREFEITURA MUNICIPAL DE RIBEIRÃO PRETO. Disponível em: <http://www.ribeiraopreto.sp.gov.br>. Acesso em 21 out. 2007.

PROCEL - Programa Nacional de Conservação de Energia Elétrica. Disponível em <www.eletrobrás.com/procel>. Acesso em 15 nov. 2007.

PUPPO, E.; PUPPO, J. A. Acondicionamiento Natural y Arquitectura. Barcelona: Marcombo, 1972.

RIVERO, Roberto. Arquitetura Clima: acondicionamento térmico natural. Porto Alegre: D.C. Luzzatto/UFRGS, 1985.

RORIZ, M. Higiene do Trabalho: temperatura. São Carlos: UFSCAR; Departamento de Engenharia de Produção. Apostila. 2001.

RORIZ, M. Zona de Conforto Térmico: Um Estudo Comparativo de Diferentes Abordagens. Dissertação de Mestrado. São Carlos: Escola de Engenharia de São Carlos USP, 1987. 
RORIZ, M.; GHISI, E.; LAMBERTS, R. Bioclimatic Zoning of Brazil: a Proposal Based in Givoni and Mahoney Methods. PLEA99 - The 16th International Conference on Passive and Low Energy Architecture. Brisbane, 1999.

SEELIG, M. F.; ZEPKA, G. S.; FOSTER, P. R. P. Aplicações de um Índice de Conforto Térmico Universal: temperatura fisiológica equivalente. In: XII Congresso Brasileiro de Meteorologia, Foz do Iguaçu: 2002.

SILVA, A. C. B. Cem Anos do Desenvolvimento Urbano de Ribeirão Preto. In: Associação Comercial e Industrial de Ribeirão Preto: Um espelho de 100 anos. Gráfica São Francisco, Ribeirão Preto: 2004.

SORRE, M. A adaptação ao meio climático e biossocial - geografia psicológica. In: MEGALE, J. F. (Org.). Max Sorre. São Paulo: Ática, 1984. (Coleção Grandes Cientistas Sociais, 46).

SZOKOLAY, S.V. Science in Architectural Education. ANZAScA'94, Deakin University, 1994.

UBER, L. L. O Ensino e a Disposição Final das Informações Climatológicas Aplicadas ao Ambiente Construído. In: II ENCAC - Encontro Nacional de Conforto no Ambiente Construído, Florianópolis: 1993.

VECCHIA, F. A. S. Cobertura Verde Leve (CVL): ensaio experimental. In: VIII Encontro Nacional e IV Encontro Latino Americano de Conforto no Ambiente Construído, Maceió: 2005. 



\section{ANEXO A}

\section{CLASSIFICAÇÕES CLIMÁTICAS}

1 - Classificação Climática de Strahler

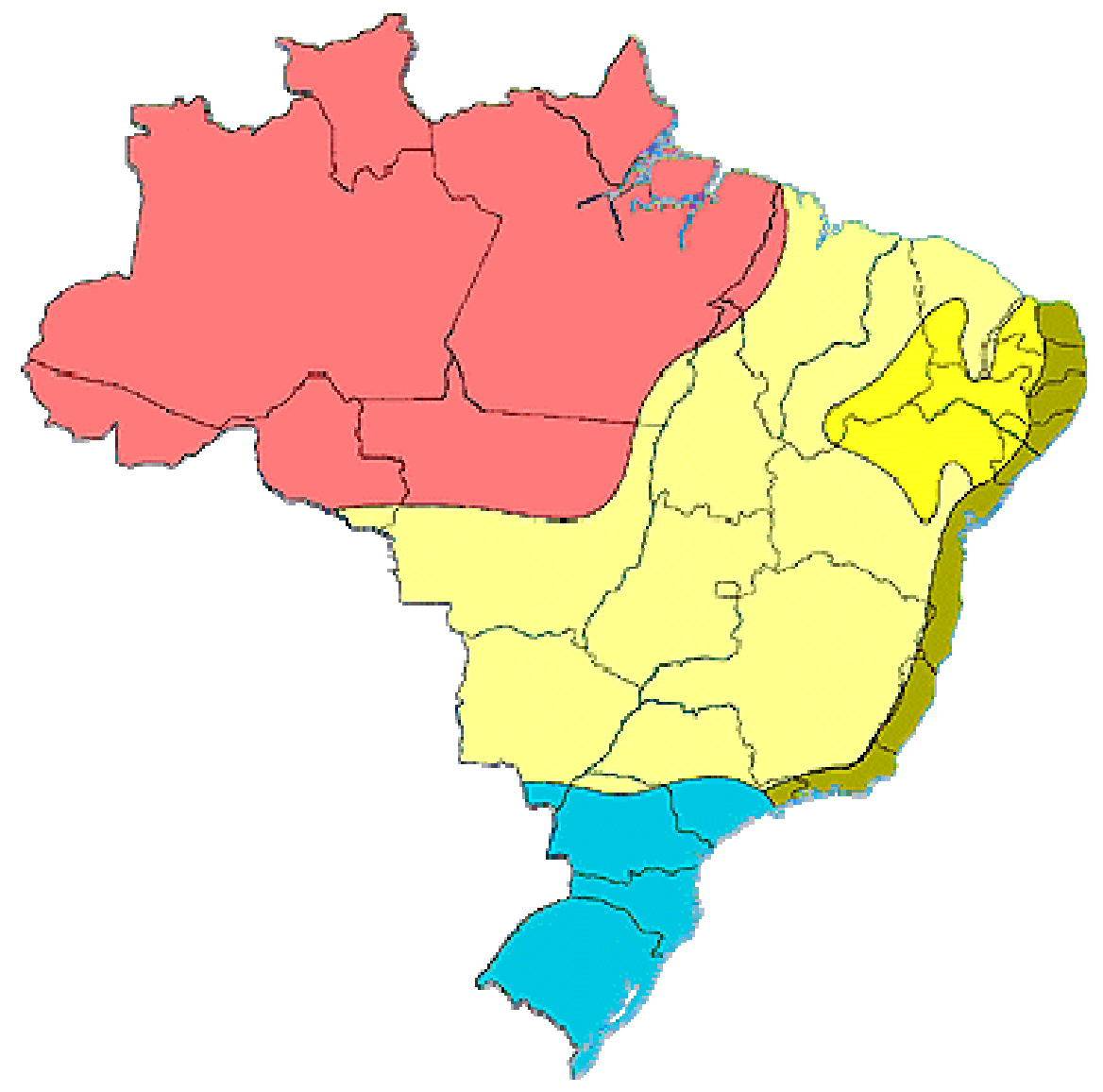

Climas Controlados por Massas de Ar Equatoriais e Tropicais

Equatorial Úmido (Convergência dos Alísios)

Tropical (Inverno seco e verão úmido)

Tropical Semi-Árido (Tendendo a seco pela irregularidade da ação das massas de ar)

Litorâneo Úmido (Influenciado pela Massa Tropical Marítima) 


\section{Climas Controlados por Massas de Ar Tropicais e Polares}

Subtropical Úmido (Costas orientais e subtropicais, com predomínio da Massa Tropical Marítima).

clima tropical: Abrange os estados de Minas Gerais e Goiás, parte de São Paulo, Mato Grosso do Sul, parte da Bahia, do Maranhão, do Piauí e do Ceará. É um clima tropical típico, quente e semi-úmido, com uma estação chuvosa (verão) e outra seca (inverno).

clima tropical semi-árido: Abrange o Sertão do Nordeste, sendo um clima tropical próximo ao árido com médias anuais de pluviosidade inferior a $1000 \mathrm{~mm}$. As chuvas concentram-se num período de três meses. No Sertão Nordestino, é uma espécie de encontro de quatro sistemas atmosféricos oriundos das massas de ar mEc, mTa, $\mathrm{mEa}, \mathrm{mPa}$.

clima litorâneo úmido: Abrange parte do território brasileiro próximo ao litoral. A massa de ar que exerce maior influência nesse clima é a tropical atlântica (mTa). Pode ser notado em duas principais estações: verão (chuvoso) e inverno (menos chuvoso), com médias térmicas e índices pluviométricos elevados; é um clima quente e úmido.

clima equatorial úmido: Abrange a Amazônia, e se caracteriza por um clima equatorial continental, quase todo o ano. Em algumas porções litorâneas da Amazônia, há alguma influência da massa equatorial atlântica, que algumas vezes (no inverno) conduz a frente fria, atingindo o sul e o sudeste da região. Embora as massas de ar sejam em geral secas, a mEc é úmida por sua localização estar sobre uma área com rios caudalosos e com cobertura da Floresta Amazônica, que possui grande umidade pela transpiração dos vegetais. Portanto, é um clima úmido e quente. As médias anuais térmicas mensais vão de $24^{\circ} \mathrm{C}$ a $27^{\circ} \mathrm{C}$, ocorrendo baixa amplitude térmica anual, com pequeno resfriamento no inverno. As médias pluviométricas são altas e a estação seca é curta. Por ser uma região de calmaria, devido ao encontro dos alísios do Hemisfério Norte com os do Sul, a maior parte das precipitações que aí ocorrem são chuvas de convecção.

clima subtropical úmido: Abrange o Brasil Meridional, porção localizada ao sul do Trópico de Capricórnio, com predominância da massa tropical atlântica, que provoca chuvas fortes. No inverno, tem freqüência de penetração de frente polar, dando 
origem às chuvas frontais com precipitações devidas ao encontro da massa quente com a fria, onde ocorre a condensação do vapor de água atmosférico. O índice médio anual de pluviosidade é elevado e as chuvas são bem distribuídas durante todo o ano, fazendo com que não exista a estação da seca.

\section{2 - Classificação Climática de Köppen}

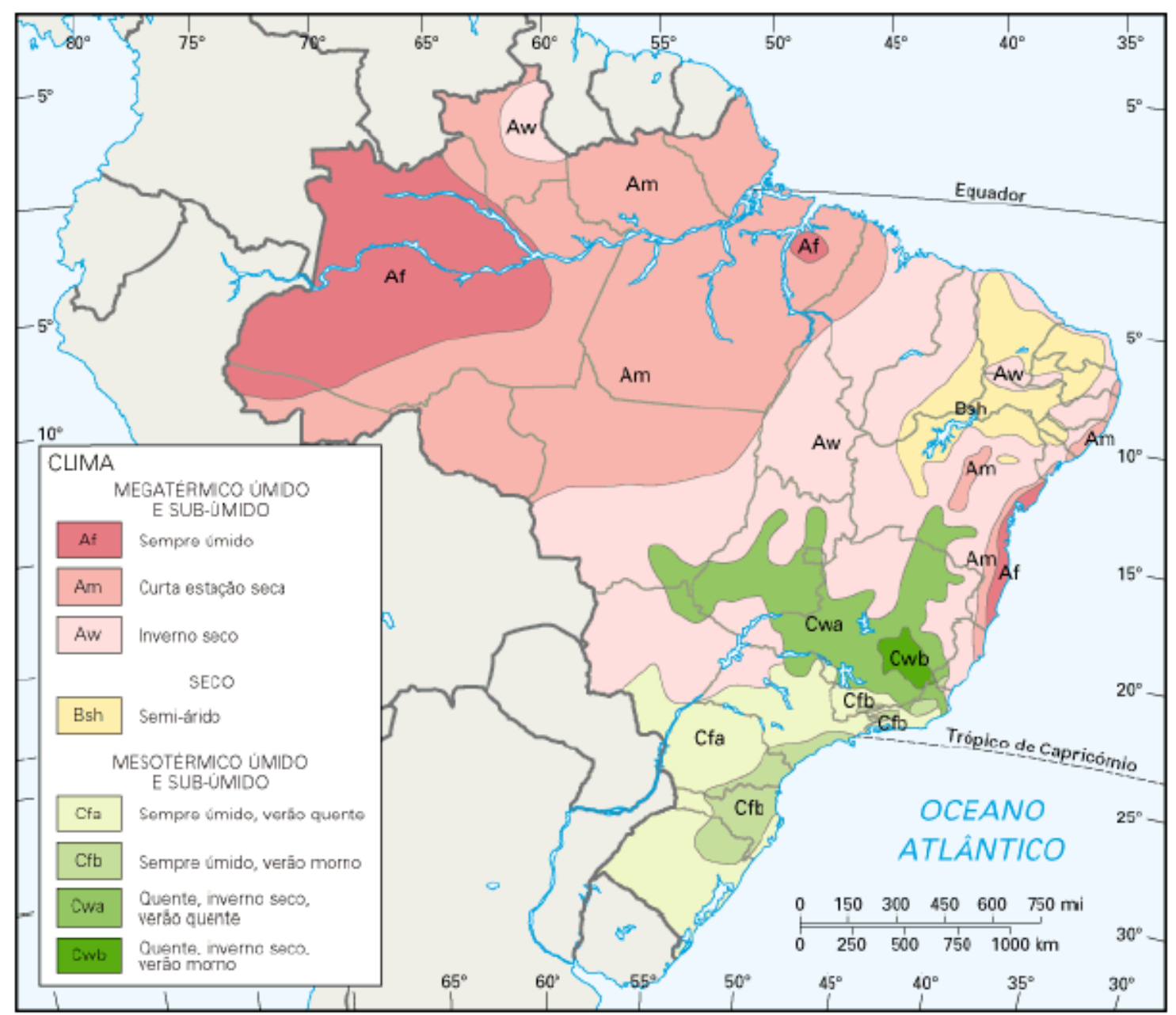

Significado dos símbolos da classificação de Köppen:

- $\quad 1^{a}$ letra - maiúscula, representa a característica geral do clima de uma região:

o A - clima quente e úmido

o B - clima árido ou semi-árido

o C - clima mesotérmico (subtropical e temperado) 
- $\quad 2^{a}$ letra - minúscula, representa as particularidades do regime de chuva:
o $\mathrm{f}$ - sempre úmido
o $\mathrm{m}$ - monçônico e predominantemente úmido
o $s$ - chuvas de inverno
o s' - chuvas do outono e inverno
o w - chuvas de verão
o w'- chuvas de verão e outono

- $\quad 3^{a}$ letra - minúscula, representa a temperatura característica de uma região:
o $\mathrm{h}$ - quente
0 a - verões quentes
o $b$ - verões brandos

\begin{tabular}{|c|c|c|c|}
\hline $\begin{array}{l}\text { Símbolos } \\
\text { Climáticos }\end{array}$ & Características & \begin{tabular}{|lr} 
Regime & de \\
Temperatura & e \\
Chuvas &
\end{tabular} & Área de Ocorrência \\
\hline Am (equatorial) & $\mid \begin{array}{ll}\text { Quente com } & \text { uma } \\
\text { estação } & \text { seca } \\
\text { (primavera) } & \end{array}$ & \begin{tabular}{|l} 
Temperaturas \\
elevadas: médias \\
entre $25^{\circ} \mathrm{C}$ e $27^{\circ} \mathrm{C}$.
\end{tabular} & $\begin{array}{l}\text { Maior parte da } \\
\text { Amazônia }\end{array}$ \\
\hline Af (equatorial) & $\begin{array}{l}\text { Quente sem estação } \\
\text { seca }\end{array}$ & $\begin{array}{|lll|}\text { Pluviosidade } & \\
\text { elevada: médias de } \\
1.500 & \text { a } & 2.500 \\
\text { mm/ano. } & \end{array}$ & $\begin{array}{l}\text { Porção oriental e } \\
\text { noroeste da região } \\
\text { Norte }\end{array}$ \\
\hline Aw (tropical) & $\begin{array}{l}\text { Quente, com chuvas } \\
\text { de verão }\end{array}$ & \multirow{2}{*}{ 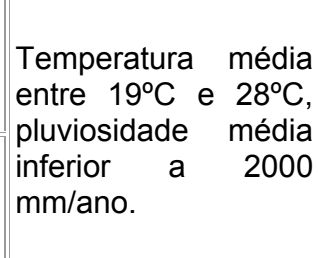 } & $\begin{array}{l}\text { Brasil Central e } \\
\text { Roraima }\end{array}$ \\
\hline Aw (tropical) & $\begin{array}{l}\text { Quente, com chuvas } \\
\text { de verão e outono }\end{array}$ & & Litoral norte \\
\hline As (tropical) & $\begin{array}{l}\text { Quente, com chuvas } \\
\text { de inverno e outono }\end{array}$ & $\begin{array}{l}\text { Duas estações bem } \\
\text { definidas: o verão } \\
\text { (chuvoso) e } \quad \text { o } \\
\text { inverno (seco). }\end{array}$ & $\begin{array}{l}\text { Litoral oriental do } \\
\text { nordeste (Zona da } \\
\text { Mata) }\end{array}$ \\
\hline \multirow{2}{*}{ Bsh (semi-árido) } & \multirow{2}{*}{$\begin{array}{l}\text { Quente e seco, com } \\
\text { chuvas de inverno* }\end{array}$} & \begin{tabular}{|lr} 
Médias & anuais \\
térmicas & superiores \\
a $25^{\circ} \mathrm{C}$. &
\end{tabular} & \multirow[b]{2}{*}{ Sertão do Nordeste } \\
\hline & & \begin{tabular}{|l} 
Pluviosidade média \\
anual inferior a 1000 \\
mm/ano com chuvas \\
irregulares.
\end{tabular} & \\
\hline
\end{tabular}




\begin{tabular}{|c|c|c|c|}
\hline $\begin{array}{l}\text { Cwb (tropical de } \\
\text { altitude) }\end{array}$ & $\begin{array}{l}\text { Chuvas de veräo e } \\
\text { verões brandos }\end{array}$ & & $\begin{array}{l}\text { Terras altas do } \\
\text { Sudeste }\end{array}$ \\
\hline $\begin{array}{l}\text { Csa (tropical de } \\
\text { altitude) }\end{array}$ & $\begin{array}{l}\text { Chuvas de } \\
\text { inverno } \\
\text { quentes }\end{array}$ & $\begin{array}{l}\text { Pluviosidade média } \\
\text { de } 1500 \text { mm/ano; } \\
\text { chuvas de verão. }\end{array}$ & $\begin{array}{lr}\text { Chapada } & \text { da } \\
\text { Borborema, região } \\
\text { Nordeste. }\end{array}$ \\
\hline Cfa (subtropical) & $\begin{array}{l}\text { Chuvas } \quad \text { bem } \\
\text { distribuídas e verões } \\
\text { rigorosos }\end{array}$ & $\begin{array}{l}\text { Médias térmicas } \\
\text { entre } 17^{\circ} \mathrm{C} \text { e } 19^{\circ} \mathrm{C} .\end{array}$ & $\begin{array}{l}\text { Áreas mais baixas } \\
\text { da região Sul (litoral } \\
\text { e sul da região) }\end{array}$ \\
\hline
\end{tabular}

\section{3 - CLASSIFICAÇÃO CLIMATICA IBGE}

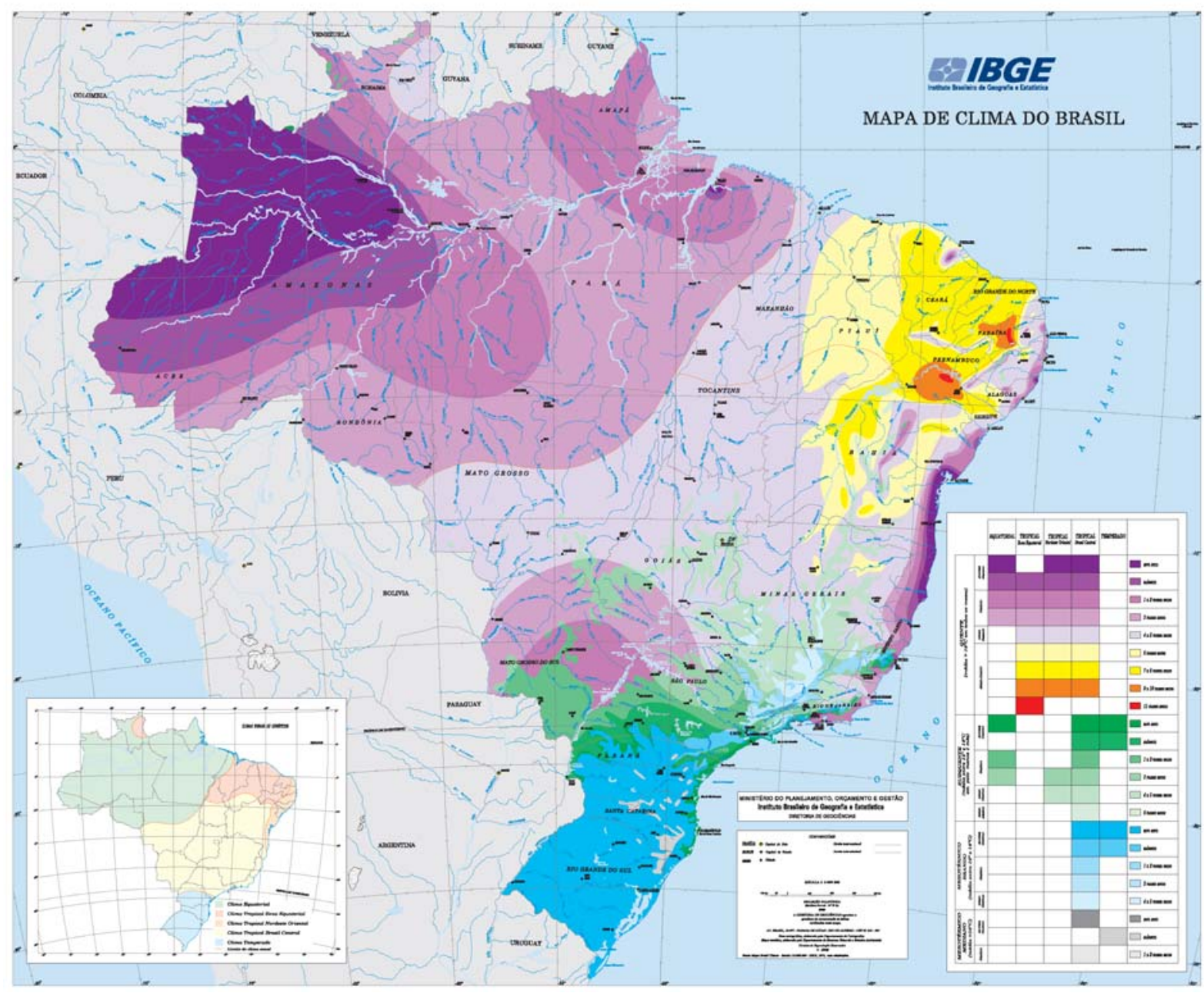




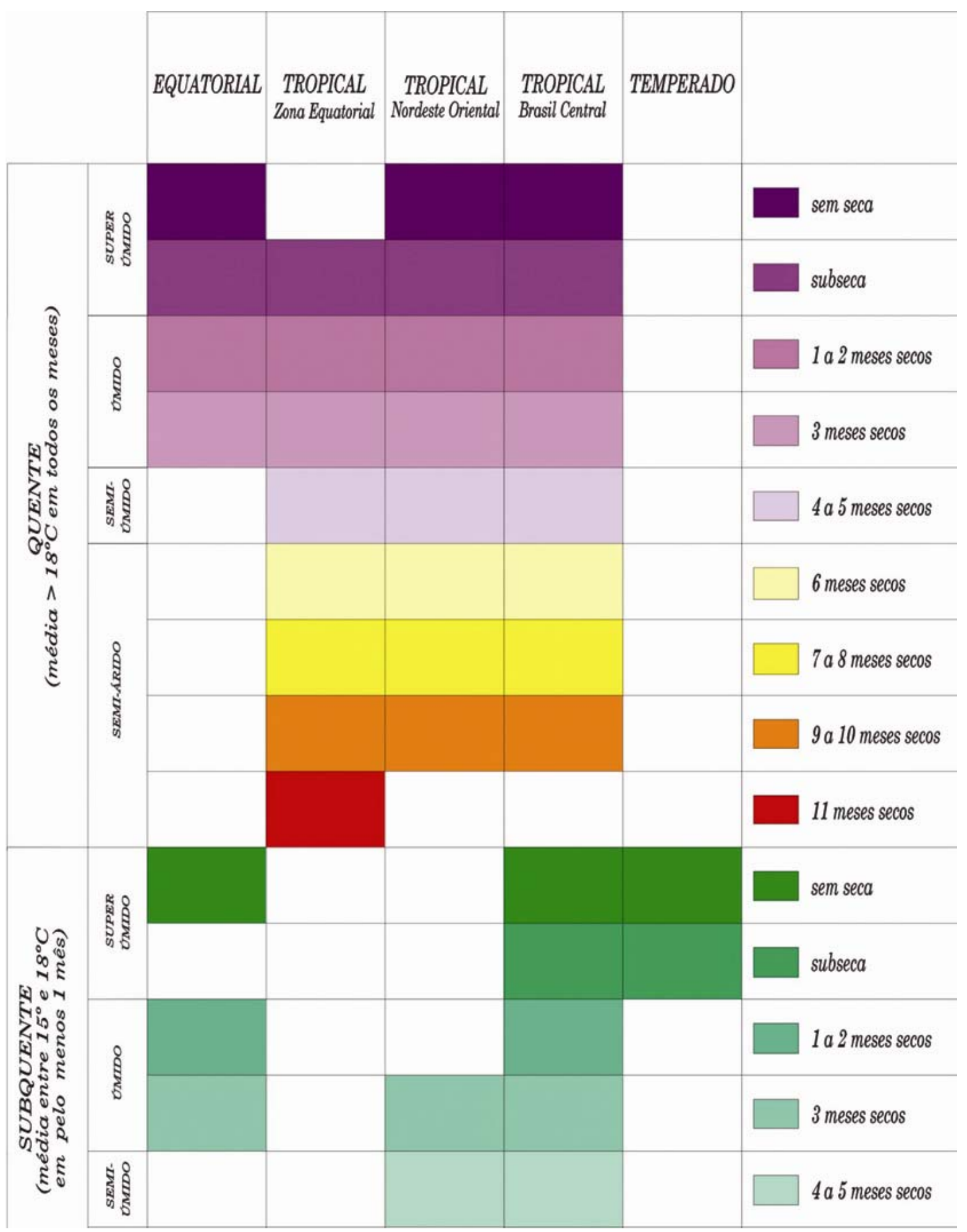




\section{ANEXO B}

\section{MÉTODO DE MAHONEY - PLANILHAS E PROCEDIMENTOS}

\section{PLANILHA 1}

\section{Quadro 1 - Dados climatológicos}

- anotar as temperaturas médias das máximas e medias das mínimas arredondandose os valores com aproximação de $0,5^{\circ} \mathrm{C}$.

- à direita, anotar a mais alta das medias das máximas (MAX) e a mais baixa das medias das mínimas (MIN)

- calcular a temperatura media anual (TMA) que é a media aritmética entre MAX e MIN

- calcular as amplitudes médias mensais (AMM) que é a diferença entre as temperaturas máximas e mínimas mensais.

- calcular a amplitude media anual (AMA) que é a diferença entre MAX e MIN

- anotar os valores mensais de umidade relativa, direção e velocidade dos ventos

- calcular o total anual das chuvas que é a soma de todos os valores mensais

Quadro 2 - Diagnósticos

- anotar o grupo de umidade correspondente a cada mês

- anotar as temperaturas médias das máximas e medias das mínimas

- registrar os limites de conforto superiores e inferiores diurnos e noturnos e de acordo com a TMA e o grupo de umidade

- comparar as máximas do dia e mínimas da noite com os respectivos limites e anotar os símbolos Q (quente), C (confortável), F (frio).

Quadro 3 - Indicadores

- anotar os indicadores correspondentes a cada mês e somar o numero total de cada indicador 


\section{PLANILHA 2}

- anotar os totais dos indicadores do quadro 3

- percorrer um a um os campos correspondentes a cada um dos nove aspectos citados, examinando as colunas dos indicadores para localizar a recomendação adequada.

-percorrer as linhas da esquerda para a direita em função do numero de vezes que cada indicador aparece

- as recomendações são excludentes, com exceção dos itens $\mathrm{F}$ e I.

- os itens G e H fornecem limites desejáveis de Coeficiente de Transmissão Térmica $(K)$, Fator de Calor Solar (q/i) e Atraso Térmico $(\varphi)$ para os elementos de vedação,

$\begin{array}{lllll}\text { que } & \text { sodem } & \text { na } & \text { ABNT }\end{array}$


\begin{tabular}{|l|l|}
\hline LOCALIZAÇÃO & RIBEIRÃO PRETO \\
\hline LONGITUDE & $21^{\circ} 10^{\prime}$ \\
\hline LATITUDE & $47^{\circ} 48^{\prime}$ \\
\hline ALTITUDE & $530 \mathrm{~m}$ \\
\hline
\end{tabular}

\begin{tabular}{|l|c|c|c|c|c|c|c|c|c|c|c|c|}
\hline TEMPERATURA DO AR $\left({ }^{\circ} \mathrm{C}\right)$ & $\mathrm{J}$ & $\mathrm{F}$ & $\mathrm{M}$ & $\mathrm{A}$ & $\mathrm{M}$ & $\mathrm{J}$ & $\mathrm{J}$ & $\mathrm{A}$ & $\mathrm{S}$ & $\mathrm{O}$ & $\mathrm{N}$ & $\mathrm{D}$ \\
\hline MEDIA MENSAL MÁXIMA & & & & & & & & & & & \\
\hline MEDIA MENSAL MINIMA & & & & & & & & & & & \\
\hline AMPLITUDE MEDIA MENSAL & & & & & & & & & & & & \\
\hline UMIDADE RELATIVA (\%) & & & & & & & & & & & & \\
\hline PRECIPITAÇÃO(mm) & & & & & & & & & & & & \\
\hline VENTOS PREDOMINANTES & & & & & & & & & & & & \\
\hline VELOCIDADE (m/s) & & & & & & & & & & & & \\
\hline
\end{tabular}

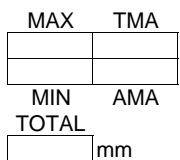

\begin{tabular}{|c|c|c|c|c|c|c|c|c|c|c|c|c|c|}
\hline & & $\mathrm{J}$ & $\mathrm{F}$ & $\mathrm{M}$ & A & $M$ & $\mathrm{~J}$ & $\mathrm{~J}$ & A & $\mathrm{S}$ & $\mathrm{O}$ & $\mathrm{N}$ & $\mathrm{D}$ \\
\hline \multicolumn{14}{|c|}{ GRUPO DE UMIDADE } \\
\hline \multicolumn{14}{|c|}{ MEDIA DAS MÁXIMAS } \\
\hline \multicolumn{14}{|c|}{ LIMITE SUPERIOR DIURNO: } \\
\hline \multicolumn{14}{|c|}{ LIMITE INFERIOR DIURNO: } \\
\hline \multicolumn{14}{|c|}{ MEDIA DAS MÍNIMAS } \\
\hline \multicolumn{14}{|c|}{ LIMITE SUPERIOR NOTURNO } \\
\hline \multicolumn{14}{|c|}{ LIMITE INFERIOR NOTURNO: } \\
\hline \multirow[t]{2}{*}{ DIAGNÓSTICO } & DIA & & & & & & & & & & & & \\
\hline & NOITE & & & & & & & & & & & & \\
\hline
\end{tabular}

\begin{tabular}{|c|c|c|c|c|c|c|c|c|c|c|c|c|c|}
\hline \multicolumn{2}{|c|}{ INDICADORES } & $\mathrm{J}$ & $\mathrm{F}$ & $M$ & A & $M$ & $\mathrm{~J}$ & $\mathrm{~J}$ & A & $\mathrm{s}$ & 0 & $\mathrm{~N}$ & $\mathrm{D}$ \\
\hline \multirow[t]{3}{*}{ UMIDADE: } & U1 & & & & & & & & & & & & \\
\hline & $\mathrm{U} 2$ & & & & & & & & & & & & \\
\hline & U3 & & & & & & & & & & & & \\
\hline \multirow[t]{3}{*}{ ARIDEZ: } & A1 & & & & & & & & & & & & \\
\hline & $\mathrm{A} 2$ & & & & & & & & & & & & \\
\hline & A3 & & & & & & & & & & & & \\
\hline
\end{tabular}

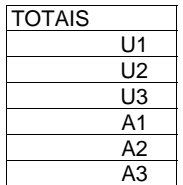

\begin{tabular}{|c|c|}
\hline GRUPO DE UMIDADE & QUANDO U.R. É: \\
\hline 1 & $<30 \%$ \\
\hline 2 & $30-50 \%$ \\
\hline 3 & $50-70 \%$ \\
\hline 4 & $>70 \%$ \\
\hline
\end{tabular}

LIMITES DE CONFORTO

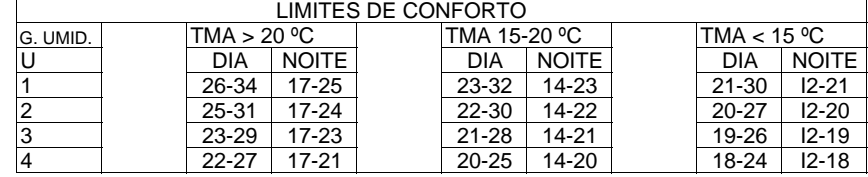

\begin{tabular}{|c|c|c|c|c|c|}
\hline \multicolumn{7}{|c|}{ INDICADORES } \\
\hline INDIC. & DIA & NOITE & CHUVA & G. UMID. & AMM \\
\hline U1 & Q & & & 4 & \\
\cline { 2 - 6 } & Q & & & 2,3 & $<10^{\circ} \mathrm{C}$ \\
\hline U2 & C & & & 4 & \\
\hline U3 & & & $>200 \mathrm{~mm}$ & & \\
\hline A1 & & & & $1,2,3$ & $>10^{\circ} \mathrm{C}$ \\
\hline A2 & & Q & & 1,2 & \\
\cline { 2 - 6 } & Q & $\mathrm{C}$ & & 1,2 & $>10^{\circ} \mathrm{C}$ \\
\hline A3 & F & & & & \\
\hline
\end{tabular}




\begin{tabular}{|c|c|c|c|c|c|}
\hline \multicolumn{1}{|c|}{ TOTAIS DOS INDICADORES } \\
\hline U1 & U2 & U3 & A1 & A2 & A3 \\
\hline & & & & & \\
\hline
\end{tabular}

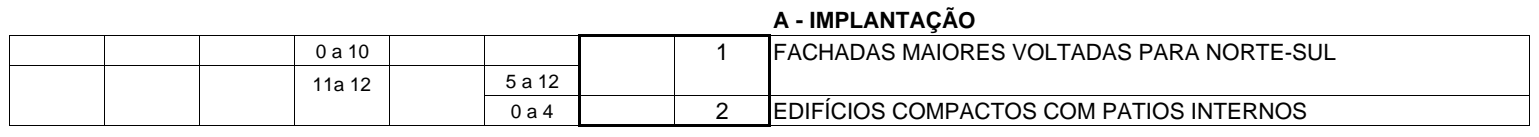

\section{B - ESPAÇAMENTOS}

\begin{tabular}{|c|l|l|l|l|l|l|l|l|}
\hline $11 \mathrm{a} 12$ & & & & & & & 3 & SEPARAÇÃO AMPLA PARA MELHOR VENTILAÇÃO \\
\hline 2 a 10 & & & & & & & 4 & COMO 3, MAS COM PROTEÇÃO PARA VENTOS QUENTES OU FRIOS \\
\hline 0 a 1 & & & & & & & 5 & DISTRIBUIÇÃO COMPACTA DOS EDIFICIOS \\
\hline
\end{tabular}

\section{C - VENTILAÇÃO}

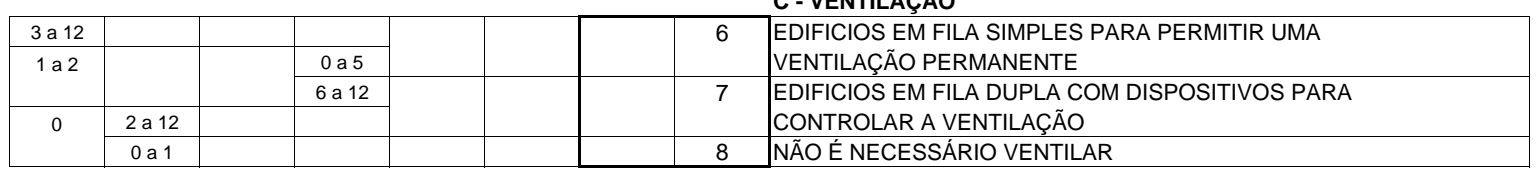

D - TAMANHO DAS ABERTURAS

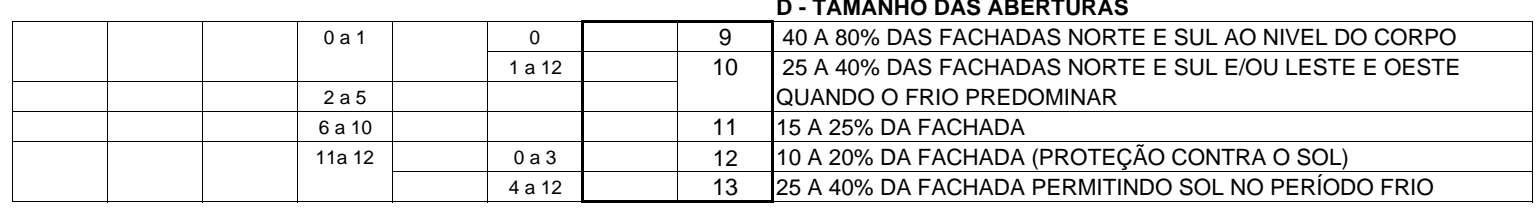

\section{E - POSIÇÃO DAS ABERTURAS}

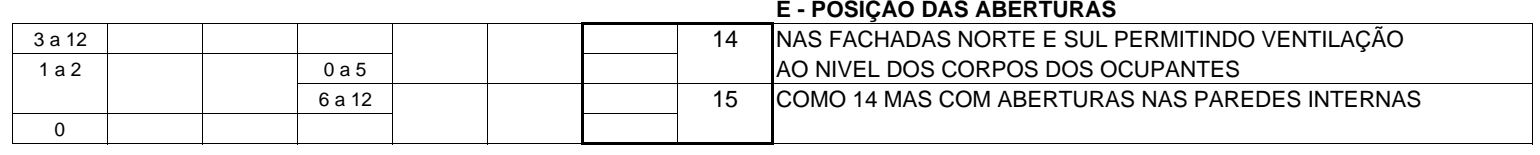

\section{F - PROTEÇÃO ABERTURAS}

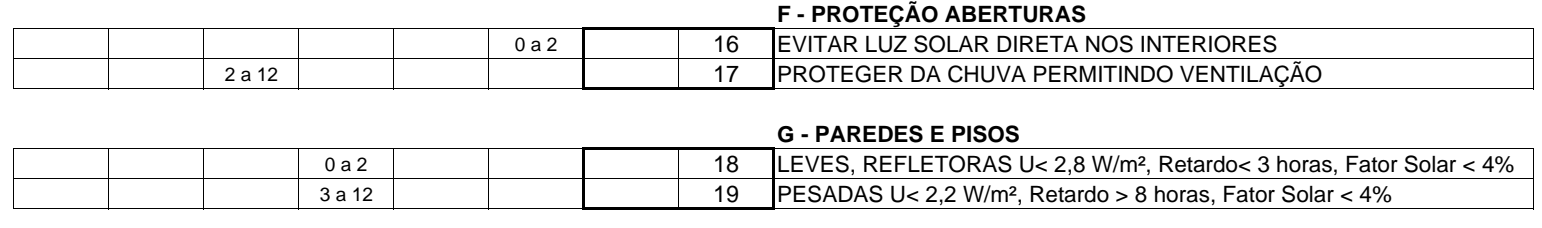

H - COBERTURAS

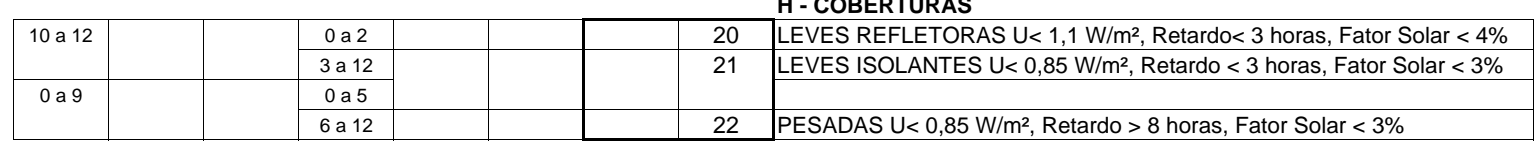

I - COMPLEMENTOS EXTERNOS

\begin{tabular}{|l|l|l|l|l|l|l|l|l|}
\hline & & & & 1 a 12 & & 0 & 23 & ESPAÇO PARA DORMIR AO AR LIVRE \\
\hline & & 1 a 12 & & & & 0 & 24 & PROTEGER CONTRA AS CHUVAS \\
\hline
\end{tabular}




\section{APÊNDICE}


Conforto térmico em edificações: Manual de projeto para Ribeirão Preto (versão preliminar)

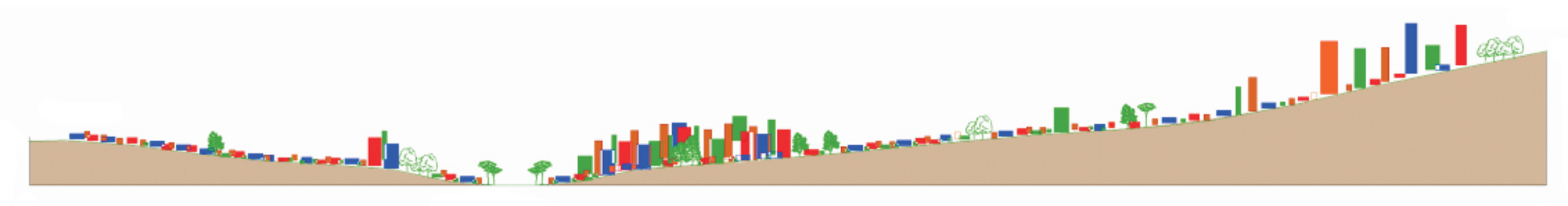




\section{ÍNDICE}

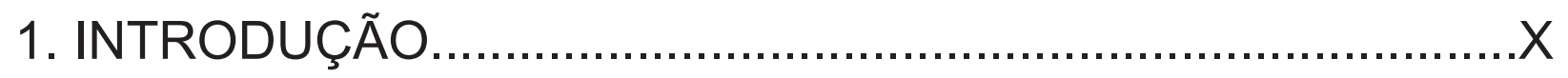

2. O CLIMA E SUA INFLUÊNCIA EM EDIFICAÇÕES..................X

3. A PRÁTICA DO PROJETO ARQUITETÔNICO FRENTE ÀS QUESTÕES DE CONFORTO TÉRMICO..............................XX

4. O CONTEXTO DE RIBEIRÃO PRETO.................................XX

5. RECOMENDAÇÕES DE PROJETO....................................XX

6. CONSIDERAÇÕES FINAIS ..............................................XX

7. REFERÊNCIAS BIBLIOGRÁFICAS....................................XX 
1. INTRODUÇÃO 
A cidade de Ribeirão Preto apresenta clima quente, com temperaturas elevadas durante praticamente todo o ano. A acelerada expansão urbana pela qual a cidade vem passando nas últimas décadas tem resultado na diminuição das áreas verdes e no aumento expressivo de áreas impermeáveis, pavimentadas e edificadas, contribuindo para o aumento da temperatura do ar no micro clima urbano. Este fator é mais um agravante no desconforto térmico causado pelo excesso de calor no interior das edificações na cidade.

Em virtude do seu clima, a questão do conforto térmico assume importância significativa nas edificações, uma vez que estas devem proteger os ocupantes das condições rigorosas de temperatura do clima local. Assim, a preocupação com o conforto térmico deve ter relevância significativa na elaboração de projetos de edificações na cidade. Porém, percebe-se que em geral as edificações não respondem às necessidades de conforto térmico, fato resultante da desconexão dos projetos com a realidade climática da cidade. Mesmo apresentando clima quente, com temperaturas elevadas durante quase todo o ano, Ribeirão Preto carece de estudos e pesquisas sobre o clima local e o conforto térmico do ambiente construído. Além disto, 
Uma série de fatores e limitações estabelece um distanciamento entre a prática do projeto arquitetônico e os conceitos de condicionamento térmico passivo em edificações.

Em vista disto, este manual insere-se na atual discussão sobre pesquisa científica e prática de projeto no que diz respeito ao conforto térmico em edificações. Tem seu foco na tentativa de se estabelecer uma aproximação entre os projetistas e o conhecimento produzido no ambiente de pesquisa, no sentido de promover a incorporação de conceitos favoráveis ao conforto térmico aos projetos de edificações na cidade. Para tanto, propõe um conjunto de recomendações de projeto específicas para a cidade Ribeirão Preto. Tais recomendações são de fácil compreensão e utilização pelos projetistas, e visam a aplicação de estratégias favoráveis ao conforto térmico de maneira simplificada e objetiva.

A elaboração deste manual contou com os dados obtidos durante o mestrado em Arquitetura e Urbanismo na área de Conforto Térmico, intitulado "Conforto Térmico e a Prática do Projeto de Edificações: recomendações para Ribeirão Preto", defendido pela autora em novembro de 2008 na Escola de Engenharia de São Carlos da Universidade de São Paulo. 
2. O CLIMA E SUA INFLUÊNCIA EM EDIFICAÇÕES 
Desde os primórdios o clima de uma localidade exerce influencia direta sobre as atividades humanas ali estabelecidas. Segundo Critchfield (1960), "a saúde e o conforto humano são mais afetados pelo clima do que por qualquer outro elemento do meio ambiente". Assim, para avaliar o conforto térmico humano é imprescindível que previamente se conheça as particularidades climáticas e fisiográficas do local em questão.

Desde as primeiras civilizações as edificações tinham o papel principal de proteger das intempéries, configurando como uma segunda vestimenta do indivíduo. O clima sempre foi o principal fator determinante na elaboração das construções e devido à ausência de mecanismos de condicionamento artificial, técnicas e materiais naturais eram amplamente utilizados como atenuantes do clima nas habitações. Assim, para as diversas zonas climáticas do planeta, encontramos respostas arquitetônicas muito distintas. Muitas vezes estas respostas vão de encontro a uma arquitetura vernacular, onde materiais e técnicas construtivas peculiares do local são utilizados de modo a propiciar melhor conforto térmico nas edificações.

Ao longo do tempo os conceitos vernaculares de proteção climática foram se perdendo gradualmente. A revolução industrial contribuiu para a 
mecanização de métodos e materiais construtivos no desenvolvimento das cidades. Assim como em outros países, as identidades construtivas típicas de cada região do Brasil foram dando lugar aos conceitos da arquitetura moderna e importação do estilo internacional. O intercambio de estilos, soluções e expressões entre afastadas regiões do mundo sem as necessárias adaptações ao novo meio satisfazem apenas as questões estético-formais do edifício. Mesmo assim, são muitas vezes apontados pela crítica como bons exemplos de arquitetura. Outro fator que contribuiu para o progressivo abandono das questões climáticas na arquitetura foi a disponibilização de equipamentos condicionadores térmicos. A possibilidade de utilização de tais equipamentos trouxe aos projetistas a falsa idéia de que preocupações como clima não eram mais relevantes, uma vez que poderiam climatizar o edifício artificialmente. Este conceito foi amplamente difundido pelo mundo, e em locais com clima quente, o aparelho condicionador de ar passou a ser a principal, ou muitas vezes a única solução para o condicionamento térmico dos ambientes.Porém, a utilização de aparelhos condicionadores em larga escala e sem critérios logo se mostrou inadequada e prejudicial à fisiologia do homem. De acordo com Rivero (1985), a utilização destes equipamentos absorve o calor que ingressa no 
ambiente, resfriando a temperatura interna do ar. Porém, as temperaturas superficiais dos elementos de vedação, como paredes e forro, permanecem inalteradas e irradiando calor para os ocupantes. Estes então, continuam a receber calor por radiação das superfícies mais quentes ao mesmo tempo em que perdem calor por convecção para o ar mais frio, o que acelera sua atividade metabólica causando desgaste físico e mental. Além disto, a utilização de equipamentos condicionadores de ar aumenta significativamente o consumo de energia das edificações, confrontando com o cenário atual de escassez de recursos energéticos. 


\subsection{ARQUITETURABIOCLIMATICA}

Em 1960, os irmãos Olgyay, pioneiros na aplicação da bioclimatologia na arquitetura, criaram a expressão 'projeto bioclimático'. O objetivo era buscar satisfazer às exigências de conforto através de técnicas e materiais disponíveis, de acordo com as características climáticas locais. Este conceito ganhou maior força na década de 70, quando ocorreram as primeiras crises energéticas. A partir daí constata-se maior preocupação com a conservação de energia e com os impactos ambientais provocados pela construção civil.

Embora muitas vezes a bioclimatologia e o condicionamento térmico natural sejam associados a uma arquitetura com identidade vernacular, cabe ressaltar que estes conceitos não possuem compromisso com conceitos vernaculares. Atualmente o constante desenvolvimento de novos materiais e tecnologias construtivas vem contribuindo para a questão do conforto térmico, ampliando o horizonte de possibilidades na aplicação de materiais e técnicas de condicionamento térmico passivo nas edificações.

Para Olgyay (1998), o projeto bioclimático pode ser definido como o que utiliza as condições favoráveis do clima com o objetivo de satisfazer as 
exigências de conforto térmico do homem. A seguir, um esquema representa um organograma para o projeto bioclimático:

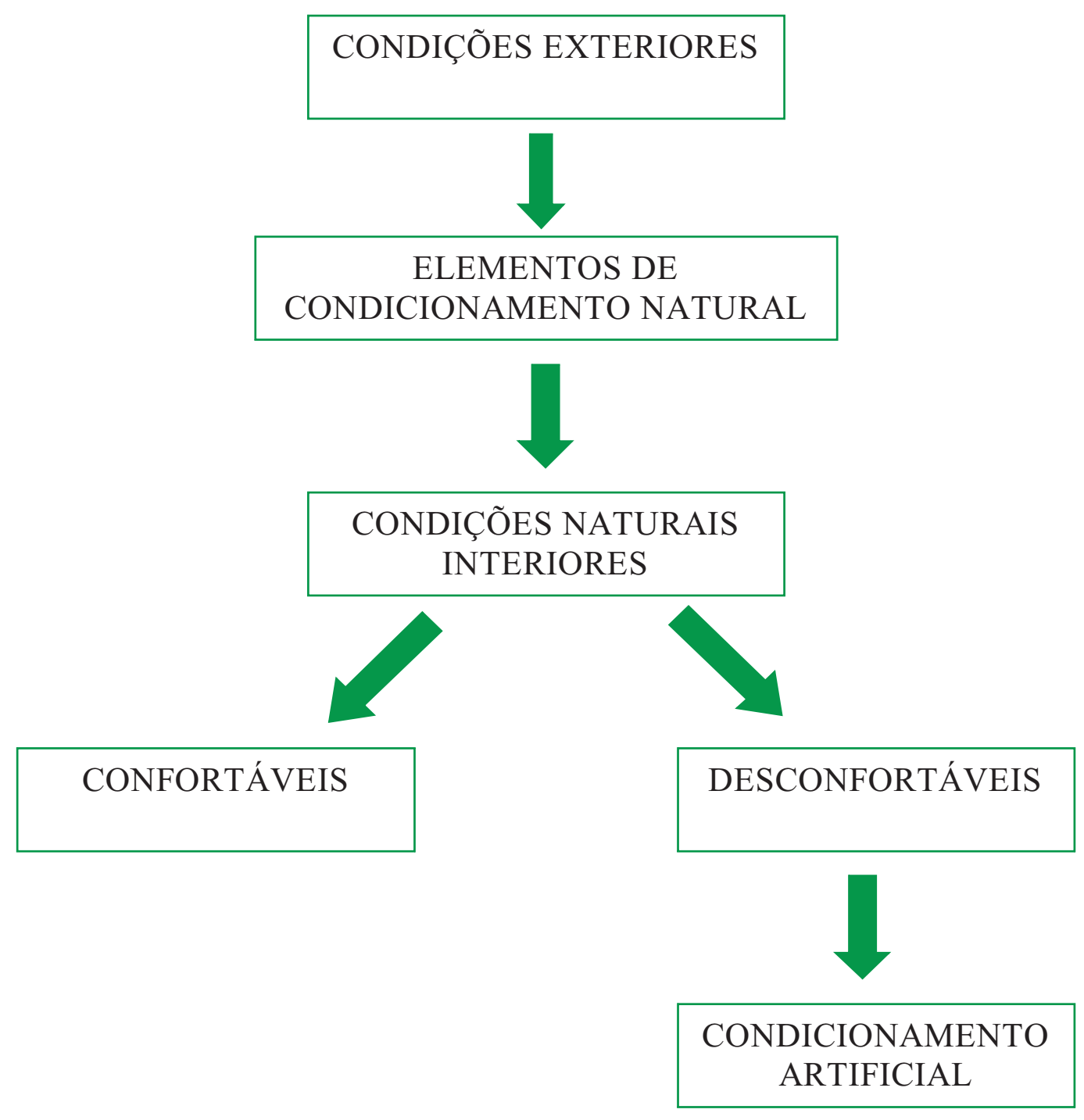


No No Brasil, a arquitetura atenta a princípios bioclimáticos, ganhou maior força na década de 60 , com a migração de arquitetos pelo território nacional. Atualmente, pode-se constatar um aprimoramento das técnicas de condicionamento passivo ao longo dos últimos anos no país. A constante evolução qualitativa e quantitativa das pesquisas em conforto térmico vem se refletindo, ainda que timidamente, na produção arquitetônica de inúmeros profissionais. Ainda assim não se pode dizer que esta produção seja significativa, pois ainda que os profissionais tenham a preocupação com o conforto térmico, esta muitas vezes acaba sofrendo limitações de projeto e por fim, cedendo espaço a outros conceitos dentro do processo de projeto.

A correta utilização dos princípios bioclimáticos pode prover conforto aos ocupantes sem que necessariamente se faça uso de mecanismos artificiais. Em se tratando de clima quente, podem se destacar duas principias estratégias de condicionamento natural: proteção à radiação solar e ventilação natural.

A ventilação natural é uma importante estratégia para a melhora no conforto humano em climas quentes, pois pode provocar uma sensação de diminuição da temperatura quando o movimento de ar facilita as trocas de 
calor entre o indivíduo e o meio, pela evapotranspiração. No ambiente construído, a ventilação pode auxiliar na retirada de calor, especialmente quando a temperatura externa é inferior à temperatura interna. O fluxo de ar nos ambientes pode configurar uma ventilação cruzada ou por efeito chaminé. A ventilação cruzada ocorre por ação dos ventos e da pressão que este exerce na edificação, através de aberturas de entrada e saída dispostas nas fachadas com pressão positiva e negativa respectivamente. Já o efeito chaminé ocorre pela diferença de temperatura que origina um fluxo ascendente, onde as aberturas possuem diferença considerável de altura, sendo a de entrada mais baixa e a de saída mais alta.

Mas, a eficiência da ventilação natural no conforto térmico dos ambientes possui algumas limitações em relação à sua aplicação em projetos. 0 dimensionamento e posicionamento entre as aberturas de entrada e saída assim como os volumes de trocas de ar, englobam cálculos complexos e conceitos de dinâmica dos fluidos. De regime variável, qualquer alteração na velocidade ou direção do vento afeta a incidência e o volume de trocas de ar no interior. Elementos externos interferem no comportamento dos ventos, podendo alterar as condições de ventilação externas e consequentemente, 
sua penetração nos ambientes internos. A ventilação nos ambientes internos também depende da operação e manuseio dos caixilhos pelos usuários.

A radiação solar é a principal responsável pelo desconforto térmico em edificações em locais de clima quente. As proteções solares são muito favoráveis uma vez que proteger a edificação da radiação contribui para minimizar o aquecimento das vedações e dos ambientes internos, melhorando suas condições térmicas. Além disto, a eficiência desta estratégia não está sujeita as alterações de tempo e elementos externos à edificação. Conhecendo a trajetória solar local, o projeto de proteções solares baseia-se em cálculos geométricos relativamente simples. 


\subsection{CONFORTO TÉRMICO E AMBIENTE CONSTRUÍDO}

O homem realiza trocas de calor com o meio, através da condução, convecção, radiação e evapotranspiração pelo suor. A quantidade de calor intercambiada por cada um dos tipos de troca de calor irá depender de algumas variáveis: a vestimenta age como uma resistência térmica entre o indivíduo e o ambiente; o tipo e intensidade de atividade física alteram a quantidade de calor gerada pelo corpo; a temperatura superficial dos elementos do ambiente determina o sentido do fluxo de calor entre o corpo e estas superfícies; a presença de radiação solar direta, temperatura, umidade e velocidade do ar influenciarão nas perdas de calor por convecção e evaporação. Alem disso, há outras variáveis que determinarão o grau de conforto, que dependem de cada indivíduo: a idade, o sexo e o grau de aclimatação. O conforto térmico é caracterizado pela sensação de bem-estar do homem, ocasionada por um ambiente em função da atuação conjunta das variáveis acima. Assim, há uma faixa de ocorrência de tais elementos, na qual o homem mantém-se em conforto térmico, ou seja, não está estressado nem por calor nem por frio. É a chamada "zona de conforto térmico". Nestas condições, ou seja, nesta faixa, o esforço termorregulatório do homem é mínimo e o desempenho em qualquer atividade é otimizado. 


\subsection{CONDICIONAMENTO TÉRMICO NATURAL E CONSUMO ENERGÉTICO EM EDIFICAÇÕES}

Nas últimas décadas, a escassez de recursos energéticos trouxe à tona a questão da racionalização de energia. Muitos estudos têm mostrado a eficiência da aplicação das estratégias de condicionamento térmico passivo na redução do consumo energético nas edificações. Assim, além dos benefícios ao conforto humano, a utilização destas estratégias no projeto de edificações torna-se relevante diante do atual cenário energético mundial.

No Brasil, considerando os setores comercial e público, o sistema de ar condicionado é responsável por cerca de $20 \%$ do consumo total de energia das edificações (GELLER, 1990). No setor residencial, uma pesquisa denominada Pesquisa de Posses e Hábitos de Uso de Aparelhos Elétricos SINPHA, vem sendo atualizada, e indica que o uso final de ar condicionado representa $20 \%$ do total de energia consumida. No ano de 1998 , esta porcentagem era de apenas 8\% (LAMBERTS et al, 2007). Não foram encontrados estudos sobre consumo de condicionadores de ar para o município de Ribeirão Preto, mas devido às altas temperaturas registradas na cidade acredita-se que o consumo relativo ao condicionamento de ar em suas edificações possa ser maior que a média nacional de $20 \%$. 
Diante disto, algumas medidas vem sendo tomadas pelo governo para a otimização do consumo energético pelas edificações. Em 2003, a partir do Programa Nacional de Conservação de Energia Elétrica (PROCEL), um programa específico para edificações foi lançado: o Programa Nacional de Eficiência Energética em Edificações (PROCEL Edifica). Este plano estabelece seis vertentes: arquitetura bioclimática, indicadores referenciais para edificações, certificação de materiais e equipamentos, regulamentação e legislação, remoção de barreiras à conservação de energia e educação. De acordo com o Ministério das Minas e Energia (MME), entre todas as ações que envolvem os planos de eficiência energética, a adequação arquitetônica seria uma das de menor investimento, podendo gerar economias de energia na ordem de $20 \%$ ao país (MME, 2007). 


\section{A PRÁTICA DO PROJETO ARQUITETÔNICO FRENTE ÀS QUESTÕES DE CONFORTO TÉRMICO}


A estruturação conceitual do projeto e as decisões tomadas a fim de atender o programa de necessidades do projeto arquitetônico estão sob a responsabilidade dos profissionais envolvidos com a construção civil, principalmente do arquiteto. O processo do projeto arquitetônico não é um processo linear e seu desenvolvimento se diferencia de um profissional ao outro. Porém, um fator comum aos profissionais é trabalhar com condicionantes básicos que são consideradas na definição do partido arquitetônico. A preocupação como o conforto térmico deve fazer parte destas condicionantes.

Nos últimos anos foram concluídos trabalhos científicos que, através de pesquisas e entrevistas com profissionais de projeto que atuam no mercado, relacionam a prática de projeto com a questão do conforto térmico no ambiente construído (CARTANA E PEREIRA , 2007); (MORISHITA E SCHIMID, 2007); (CHVATAL, 1998); (MACIEL, 2006).Apesar do crescente avanço no ambiente de pesquisas em conforto térmico, os estudos apontam uma lacuna entre a produção científica e a prática profissional. Apesar de uma parcela considerável de profissionais julgar imprescindível o conforto térmico natural em edificações, estes não fazem uso freqüente de 
ferramentas e estratégias que propiciem maior conforto em seus projetos.

Este panorama é decorrente de limitações sofridas durante o processo de projeto das mais variadas ordens. Dentre estas limitações, os profissionais entrevistados destacam: terrenos pequenos com orientações desfavoráveis, edificações muito próximas, falta de interesse do cliente, custo alto de algumas soluções, falta de fontes de informação e falta de tempo. A ventilação natural é pouco explorada devido à complexidade do estudo dos ventos, da relação entre o posicionamento e dimensionamento das aberturas e dos cálculos de volumes de trocas de ar.Outro fator limitante aos arquitetos é a consciência dos construtores e incorporadores como clientes do arquiteto. Nestes casos, a adoção de estratégias de condicionamento térmico natural depende de maior criatividade do profissional em apontar soluções economicamente viáveis para o empreendedor.

Dentre as necessidades apontadas pelos autores, destaca-se a carência de ferramentas de projeto que traduzam o conhecimento científico para a prática projetual, fornecendo recomendações de projeto para o local em questão. Tais ferramentas devem ser informativas, de fácil compreensão e utilização, auxiliando os profissionais na tomada de decisões sobre o conforto térmico 
ainda no estágio inicial do processo do projeto. Ainda que de maneira geral, estas recomendações subsidiam a correta adoção de estratégias de condicionamento térmico nos projetos. Além disto, apontam a necessidade de um planejamento urbano que contemple os aspectos do conforto ambiental no que se refere ao aumento de áreas verdes, orientação e espaçamento dos lotes e verticalização.

Vários países europeus, como Alemanha e Reino Unido, possuem códigos de edificações que consideram o conforto térmico no ambiente construído. Os arquitetos entrevistados que atuam nestes países consideram os códigos bastante influentes pois a presença das questões de conforto nos códigos estimula a integração de questões bioclimáticas no projeto e vêm influenciando na sensibilidade do mercado e dos profissionais quanto a importância do conforto térmico nas edificações. O tema educação também é abordado, sendo que todos os arquitetos entrevistados defendem que as escolas devem assumir um compromisso ético para a disseminação e integração de questões ambientais nos cursos de arquitetura.

Atualmente no Brasil, em termos de regulamentação, além do PROCEL Edifica, há a norma da Associação Brasileira de Normas Técnicas (ABNT) 
NBR 15220 - Desempenho Térmico de Edificações (ABNT, 2007). Esta foi elaborada com o objetivo de melhorar o desempenho térmico das edificações no Brasil através de melhor adequação climática. É dividida em cinco partes, sendo que a terceira parte apresenta recomendações e diretrizes construtivas quanto ao desempenho térmico de habitações unifamiliares de interesse social aplicáveis na fase de projeto.Em virtude da grande área do país, a abrangência nacional do zoneamento climático desta norma pode levar a recomendações generalizadas, que atendam a uma determinada cidade e não a outra, ainda que pertençam à mesma zona climática. Mesmo assim, as recomendações da NBR 15220 são de grande importância para o país e representam um significativo passo na incorporação das questões de conforto térmico nos projetos de edificações.

Cabe ressaltar que muitas vezes as respostas para as questões de conforto térmico de uma edificação estão em simples decisões de projeto em relação à implantação do edifício e orientação das fachadas, aberturas e superfícies transparentes. Ao contrário do que pode se pensar, tais estratégias podem ter maior eficiência no conforto térmico do que a adoção de materiais e tecnologias especiais. Assim, as questões sobre condicionamento térmico 
devem ser consideradas em todas as fases do processo de projeto. A fase preliminar já deve considerar a relação do edifício com o clima local e assim prever posicionamento, volumetria e distribuição que se apropriem dos fatores positivos e minimizem os fatores negativos deste clima. Na fase de anteprojeto, devem ser previstos os materiais e técnicas de condicionamento passivo que contribuirão para o conforto térmico na edificação. Considerar a questão do conforto térmico apenas na fase final do processo de projeto pode levar à limitações de execução, minimizando as possibilidades de condicionamento térmico natural. 
4. O CONTEXTO DE RIBEIRÃO PRETO 
O município de Ribeirão Preto situa-se na região nordeste do estado São Paulo, a $21^{\circ} 10^{\prime} 42^{\prime \prime}$ de latitude Sul e $47^{\circ} 48^{\prime} 42^{\prime \prime}$ de longitude Oeste, ocupando uma área de aproximadamente $651 \mathrm{~km}^{2}$. O relevo é suavemente ondulado, onde a região central encontra-se em área de fundo de vale, com altitudes em torno de 530 metros, e é circundada por áreas mais elevadas, chegando a 800 metros de altitude ao sudeste, na divisa com a cidade de Cravinhos.

Analisando o corte representativo na figura 4.1, pode-se ver na área mais baixa a região central, que possui ocupação mista com edificações baixas e altas. Ao redor do centro ocorrem elevações em todas as direções geográficas, mas é nos sentidos sul, sudeste e sudoeste que estas ocorrem de maneira mais acentuada. Sabe-se que a direção predominante dos ventos na cidade é do quadrante sul. Portanto esta conformação do relevo prejudica a penetração dos ventos dominantes em grande parte da área urbana. O relevo característico da cidade, a substituição de áreas de vegetação natural por monoculturas e o aumento de áreas edificadas em detrimento de áreas verdes atuam como fatores modificadores das condições iniciais do clima. No caso de Ribeirão, estes fatores vêm contribuindo para o aumento de temperatura no microclima urbano. 


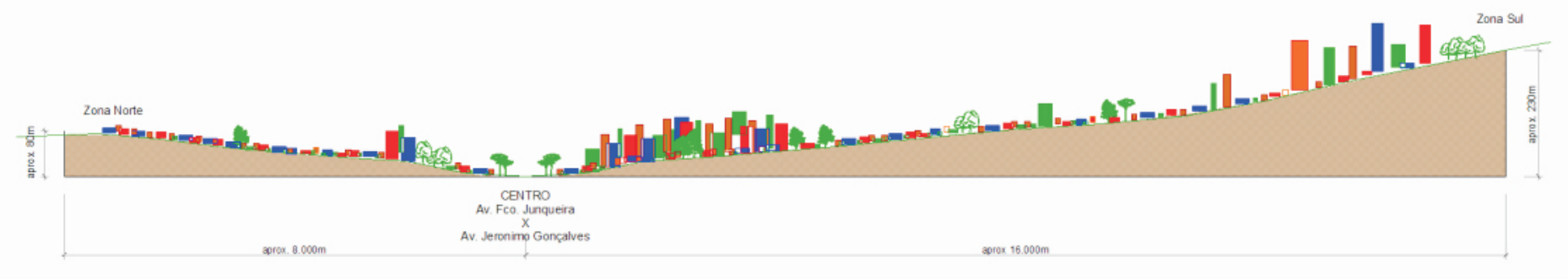

A expansão urbana direcionou-se essencialmente para a zona sul, caracterizando este como o vetor de crescimento da cidade nas últimas duas décadas. Trata-se de uma área nobre pelo dimensionamento dos lotes, padrão das edificações e pelo seu valor comercial. É também uma área privilegiada em relação à área central, pois além de ser pouco adensada devido às restrições de recuos locais, encontra-se em região mais elevada e, portanto, com melhores condições de temperatura e incidência de ventos. 


\subsection{LEGISLAÇÃO CONSTRUTIVA}

O Código de Obras de uma cidade tem o importante papel de regulamentar e legislar a ocupação e as construções de uma cidade e também de informar os profissionais que ao desenvolverem um projeto frequentemente o utilizam como material de consulta. O Manual do Código de Obras é um instrumento de democratização da informação amplamente utilizado pelos profissionais na elaboração dos projetos. Uma vez que nele constam leis com parâmetros construtivos para edificações, é de se esperar que estas leis estejam baseadas em estudos aprofundados e voltados para a cidade em questão, levando em conta suas peculiaridades. Assim, em relação aos parâmetros relacionados às questões de conforto térmico, devem ser consideradas as condições climáticas que caracterizam a cidade em questão.

Porém, como em muitas localidades, atual Código de Obras de Ribeirão Preto não aborda de maneira apropriada a questão do conforto térmico. Alguns parâmetros que influenciam no conforto, como dimensionamento para iluminação e ventilação, refletem uma preocupação apenas com a salubridade mínima do ambiente, uma vez que o Código baseia-se em antiga lei sanitarista do estado de São Paulo. 


\subsection{EDIFICAÇÕES E CONFORTO TÉRMICO NA CIDADE}

As edificações em Ribeirão Preto, em sua grande maioria, apresentam os seguintes materiais construtivos para as vedações externas: paredes em tijolo cerâmico furado rebocado de ambos os lados, forro em laje mista e cobertura em telha cerâmica com estrutura de madeira. A utilização destes materiais está relacionada mais à questões econômicas do que a questões de conforto térmico. Quando há maior preocupação com o conforto térmico, frequentemente os profissionais optam pela utilização do tijolo cerâmico maciço por acreditarem ser uma melhor opção frente ao tijolo furado.

Primeiramente é preciso ressaltar que as condições de conforto térmico de um ambiente dependem de vários fatores, sendo a composição do material de vedação apenas um deles. Assim, a simples definição de um material pode ser insuficiente para resolver as questões de conforto térmico. Além disto, diferenças de valores numéricos nas propriedades térmicas dos materiais podem não se refletir significativamente na temperatura interna de um ambiente. Deve-se também observar a relevância de cada vedação externa em relação ao tipo de edificação. Em geral, a cobertura é o componente de maior absorção de calor em edificações térreas, enquanto nos edifícios altos sãos as vedações verticais as 
maiores responsáveis pela absorção de calor. Em relação às paredes, a utilização de materiais adequados ao clima quente pode ter seu desempenho térmico comprometido pela orientação inadequada desta ou pela presença de grandes áreas envidraçadas. Assim, no caso de Ribeirão Preto, fatores como orientação favorável e proteções solares podem ter maior influência nas temperaturas internas dos ambientes que os materiais das vedações.

Os sistemas de cobertura geralmente estão em posição próxima ao plano horizontal, e por isso recebe incidência da radiação direta durante quase todo o período diurno. Em um clima quente como o de Ribeirão Preto, isso significa um enorme ganho de calor por esta superfície, que consequentemente contribuirá para o aquecimento excessivo dos ambientes internos.

Vê-se em muitas edificações a adoção de materiais e tipologias prejudiciais ao conforto térmico em função de questões estéticas e do status do edifício, havendo certa dificuldade em encontrar exemplares que tenham uma relação positiva entre as questões de conforto térmico e o clima da cidade. Em alguns casos percebe-se que há a preocupação com o conforto térmico por parte do profissional, que buscam utilizar estratégias de condicionamento passivo. Porém, muitas vezes as estratégias de condicionamento natural são 
utilizadas com base apenas na intuição do profissional de projeto. Outras vezes, são utilizados materiais com base nas informações de catálogos dos fabricantes, sendo estas muitas vezes imparciais ou incompletas.

Assim como em outros locais, em Ribeirão Preto há uma lacuna entre a prática do projeto de edificações e as pesquisas em conforto térmico. Ainda que haja a preocupação com o conforto térmico por parte dos profissionais, muitas vezes estes se deparam com algumas limitações durante o processo de projeto. Mais uma vez destaca-se a importância de uma ferramenta de projeto que aproxime o profissional projetista do ambiente de pesquisa e forneça subsídios para a incorporação das questões de conforto de maneira correta em seus projetos. 


\subsection{CARACTERISTICAS DO CLIMA EM RIBEIRÃO PRETO}

Há o consenso entre os autores pesquisados que os principais aspectos climáticos que agem diretamente sobre a edificação e, portanto, no conforto ambiental da mesma são: Temperatura, Umidade Relativa, Ventos, Radiação Solar e Precipitações. Porém, alguns destes fatores podem ter maior ou menor relevância no conforto térmico em cada localidade. A seguir, são apresentados os dados climáticos de Ribeirão Preto de acordo com a estação meteorológica do IAC, destacando o comportamento destes e sua relevância para o clima local.

Tabela 4.1 - Dados de temperatura de Ribeirão Preto (Estação Meteorológica do IAC).

\begin{tabular}{|l|l|l|l|l|l|l|l|l|l|l|l|l}
\hline & JAN & FEV & MAR & ABR & MAIO & JUN & JUL & AGO & SET & OUT & NOV & DEZ \\
\hline MAX ABS $^{\circ} \mathbf{C}$ & 33,5 & 33,5 & 33,4 & 32,0 & 30,4 & 29,7 & 30,4 & 33,6 & 35,2 & 35,3 & 34,5 & 33,7 \\
\hline MED MAX $^{\circ} \mathbf{C}$ & 29,9 & 30,3 & 30,2 & 29,1 & 27,0 & 26,1 & 26,7 & 29,0 & 30,3 & 30,4 & 30,1 & 29,5 \\
\hline MIN ABS $^{\circ} \mathbf{C}$ & 15,8 & 16,1 & 14,7 & 11,8 & 8,1 & 5,8 & 5,8 & 7,3 & 10,0 & 12,3 & 13,3 & 14,8 \\
\hline MED MIN $^{\circ} \mathbf{C}$ & 18,7 & 18,6 & 17,9 & 16,1 & 13,5 & 12,1 & 11,9 & 13,5 & 15,6 & 17,0 & 17,6 & 18,4 \\
\hline MEDIAS $^{\circ} \mathbf{C}$ & 24,3 & 24,4 & 24,0 & 22,6 & 20,3 & 19,1 & 19,3 & 21,2 & 22,9 & 23,7 & 23,9 & 24,0 \\
\hline
\end{tabular}

O período quente tem grande representatividade no ano, sendo que durante nove meses, de agosto a abril, a temperatura média das máximas está acima de $29^{\circ} \mathrm{C}$. Os meses de outubro e setembro apresentam as maiores medis das máximas $\left(30,4^{\circ} \mathrm{C}\right.$ e $30,3^{\circ} \mathrm{C}$ respectivamente) e também as maiores máximas 
absolutas $\left(35,3^{\circ} \mathrm{C}\right.$ e $35,2^{\circ} \mathrm{C}$ respectivamente). $\mathrm{O}$ fato de os meses de verão (dezembro e janeiro) apresentarem temperaturas menores deve-se à maior ocorrência de chuvas, que contribui para um menor aquecimento. O período frio, de maio a julho, tem pouca representatividade no ano. Mesmo nestes meses as médias das máximas ficam entre $26^{\circ} \mathrm{C}$ e $27^{\circ} \mathrm{C}$, o que leva a considerar os período diurno como confortável, e não como frio.

Tabela 4.2 - Dados de umidade relativa de Ribeirão Preto (Estação Meteorológica do IAC).

\begin{tabular}{|l|l|l|l|l|l|l|l|l|l|l|l|l}
\hline & JAN & FEV & MAR & ABR & MAIO & JUN & JUL & AGO & SET & OUT & NOV & DEZ \\
\hline UMID REL $\%$ & 80,5 & 81,1 & 80,2 & 73,2 & 74,4 & 70,5 & 64,9 & 57,1 & 62,2 & 68,4 & 73,6 & 80,3 \\
\hline
\end{tabular}

A umidade relativa média varia entre $81,1 \%$ e $57,1 \%$ ao longo do ano. Os meses mais úmidos são de dezembro a março, quando a umidade é maior que $80 \%$.Os meses mais secos são de julho a outubro, quando a umidade fica abaixo de $70 \%$. Destaca-se aqui a ocorrência de um período quente e úmido, de dezembro a março, com temperaturas e umidades relativas altas, e um período quente e seco, de agosto a outubro, com temperaturas altas e umidades baixas. Cabe ressaltar que valores médios de umidade podem não mostrar ocorrências específicas locais. No caso de Ribeirão Preto, a umidade relativa varia consideravelmente durante um dia, apresentando valores mais 
baixos no período da tarde. Durante os meses mais secos a umidade relativa frequentemente atinge valores críticos abaixo de $20 \%$.

Tabela 4.3 - Dados de pluviosidade de Ribeirão Preto (Estação Meteorológica do IAC).

\begin{tabular}{|l|l|l|l|l|l|l|l|l|l|l|l|l}
\hline & JAN & FEV & MAR & ABR & MAIO & JUN & JUL & AGO & SET & OUT & NOV & DEZ \\
\hline $\begin{array}{l}\text { CHUVAS } \\
\text { mm }\end{array}$ & 260,2 & 217,7 & 163,4 & 82,8 & 60,4 & 31,8 & 24,4 & 25,7 & 57,1 & 136,9 & 173,1 & 285,9 \\
\hline
\end{tabular}

A média de precipitação no ano é de $1519,4 \mathrm{~mm}$. O ano pode ser dividido em seis meses chuvosos, com precipitação acima de $137 \mathrm{~mm}$, e seis meses de seca, com precipitação abaixo de $83 \mathrm{~mm}$. Porém, nos meses de dezembro, janeiro e fevereiro ocorre mais de $50 \%$ das chuvas, revelando uma má distribuição destas ao longo do ano.

Tabela 4.4 - Dados de vento de Ribeirão Preto (Estação Meteorológica do IAC).

\begin{tabular}{|l|l|l|l|l|l|l|l|l|l|l|l|l}
\hline & JAN & FEV & MAR & ABR & MAIO & JUN & JUL & AGO & SET & OUT & NOV & DEZ \\
\hline VEL m/s & 1,6 & 1,4 & 1,3 & 1,5 & 1,4 & 1,4 & 1,8 & 2,0 & 2,3 & 2,3 & 2,2 & 1,9 \\
\hline DIR. & NW & SE & SE & SE & SE & SE & SE & SE & SE & SE & SE & SE \\
\hline
\end{tabular}

A predominância dos ventos é de sudeste durante onze meses do ano. Os meses de setembro, outubro e novembro apresentam maiores velocidades médias, sendo este o período quente e seco. Cabe ressaltar que as medidas 
apresentadas são aferidas a 10 metros de altura do solo e em área descampada, devendo-se considerar que em zonas adensadas certamente ocorre redução destas velocidades.

Para estimar os impactos da radiação solar sobre determinada superfície, é necessário conhecer a quantidade de radiação recebida em watts por metro quadrado $\left(\mathrm{W} / \mathrm{m}^{2}\right)$. Este valor depende dos ângulos de incidência do sol sobre esta superfície. Tais angulos podem ser observados a partir da leitura da carta solar para a latitude de Ribeirão Preto (figura 4.1).

A partir desta carta, fez-se o traçado dos ângulos de incidência e a quantificação do tempo de incidência para oito fachadas com orientações distintas: Norte, Nordeste, Leste, Sudeste, Sul, Sudoeste, Oeste e Noroeste. Foram considerados os meses de Setembro, Dezembro e Março, que correspondem ao período mais quente, quando a radiação direta é mais prejudicial ao conforto térmico no caso de Ribeirão Preto. Este traçado permite observar a trajetória solar na cidade assim como sua incidência em fachadas, facilitando a previsão e projeto de proteções solares para aberturas e superfícies expostas à radiação solar. 


$$
\text { هو }
$$




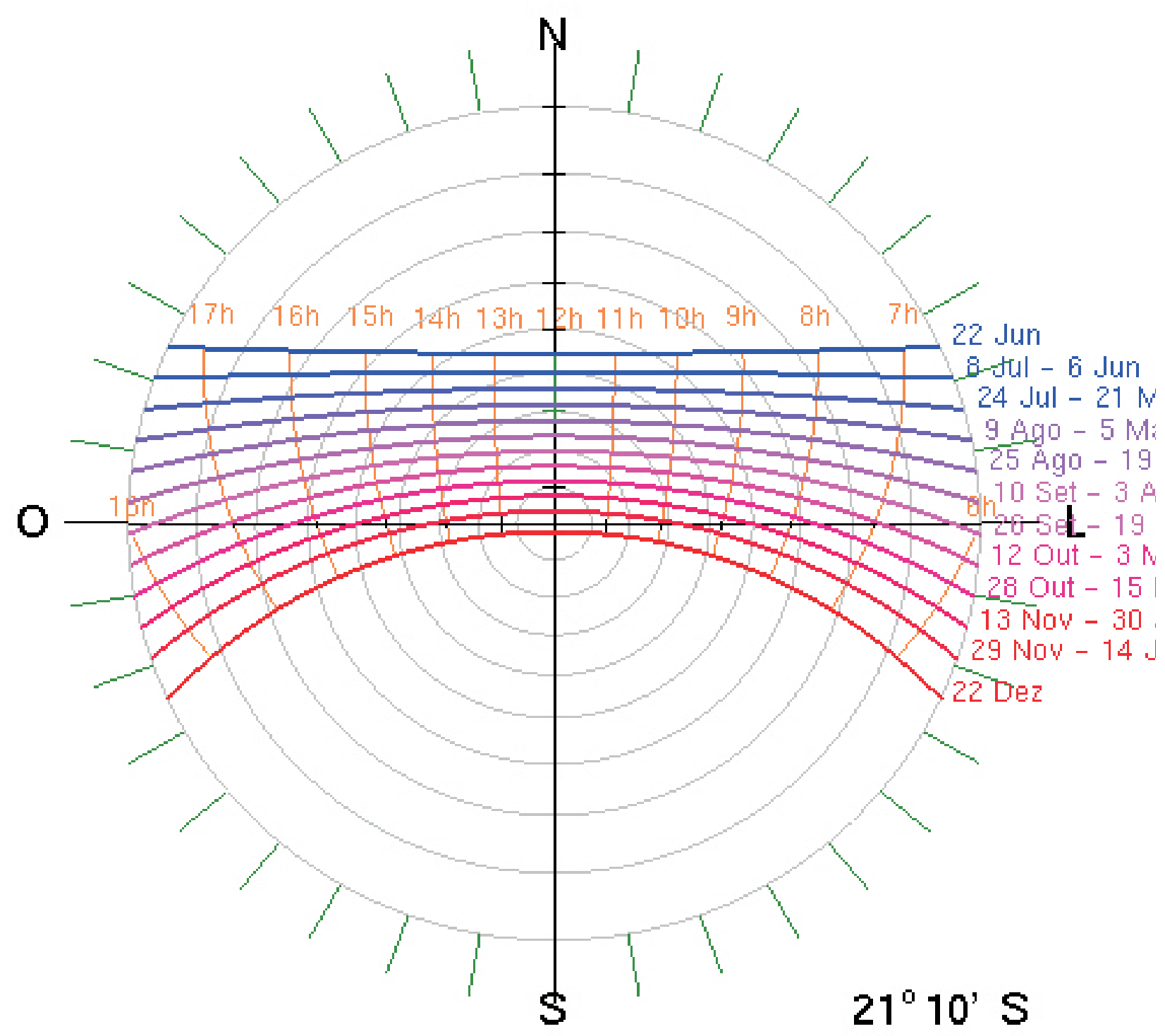

Figura 4. 1 Carta Solar para latitude 21¹0' S. (BITENCOURT, 2004). 
Se uma superfície recebe insolação direta no período da tarde, os picos de quantidades de Watts recebidos por radiação coincidem com os picos de temperatura, resultando no aumento excessivo de temperatura, o que é prejudicial ao conforto em climas quentes como o da cidade de Ribeirão Preto. Para avaliar o comportamento de cada orientação de fachada no período diurno, quando as temperaturas são mais altas, foram comparados os dados de radiação global incidente $(\mathrm{lg})$ com dados de temperatura $(T)$ para cada hora do dia . Foram considerados os meses de Setembro, Dezembro e Março por compreenderem o período mais quente do ano e também devido à disponibilidade de dados de radiação somente para estes meses.

Para se comparar as orientações mais favoráveis do ponto de vista do aumento de temperatura decorrente do ganho de calor por radiação, serão considerados dois critérios. O primeiro é a ocorrência simultânea de picos de temperatura com picos de radiação no período da tarde, entre $12 \mathrm{~h} 00 \mathrm{~min}$ e $18 \mathrm{~h} 00 \mathrm{~min}$. O segundo é a quantidade total de radiação global recebida ao longo do dia pela superfície.O cruzamento dos dois critérios resultou em uma classificação de orientações que leva em conta a quantidade de ganho de calor no período da tarde, de acordo com o esquema abaixo: 


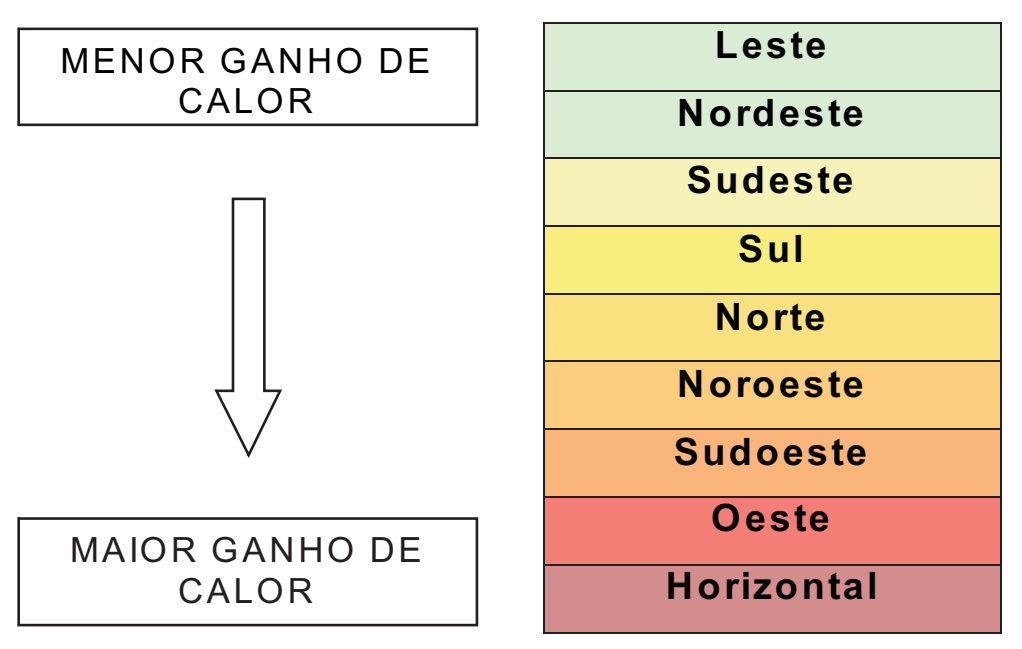

Figura 4.2 - Classificação de fachadas segundo ganho de calor por radiação no período da tarde para a latitude de $21^{\circ} 10^{\prime} S$. (RIBEIRO, 2008)

A classificação acima pode auxiliar na tomada de decisões em relação à implantação de edificações no sentido de evitar o sobreaquecimento em ambientes onde este fator seja indesejável e orientar para as fachadas com maior incidência os ambientes onde este fator não seja tão prejudicial.

O clima de Ribeirão Preto, composto por um período quente e úmido e outro quente e seco, requer maior cuidado nas recomendações para que se alcance um conforto térmico satisfatório nas edificações durante todo o período quente. Considerando este fator, reúnem-se no próximo capítulo recomendações de projeto sobre diversos aspectos construtivos visando melhor desempenho térmico nas edificações da cidade. 
5. RECOMENDAÇÕES DE PROJETO 


\subsection{IMPLANTAÇÃO, DISTRIBUIÇÃO E FORMA DO EDIFÍCIO}

As edificações devem ser alongadas e bem espaçadas entre si com amplos recuos, que permitam boa ventilação entre estas. A forma dos edifícios deve minimizar áreas de vedações externas expostas à radiação direta.

Indica-se a setorização do programa, de maneira a dispor os ambientes de baixa permanência nas áreas mais críticas, e os ambientes de longa permanência em áreas mais privilegiadas, com menor incidência solar, boas condições de ventilação e próximas a áreas sombreadas e com vegetação.

Um elemento favorável às edificações na cidade é a utilização de pátios internos, sombreados, com vegetação e se possível com presença de água. Os pátios podem configurar vedações externas com aberturas não expostas à radiação direta e através de conexões com os ambientes internos, podem proporcionar a circulação de ar com melhores condições de temperatura e umidade do que o ar externo. 

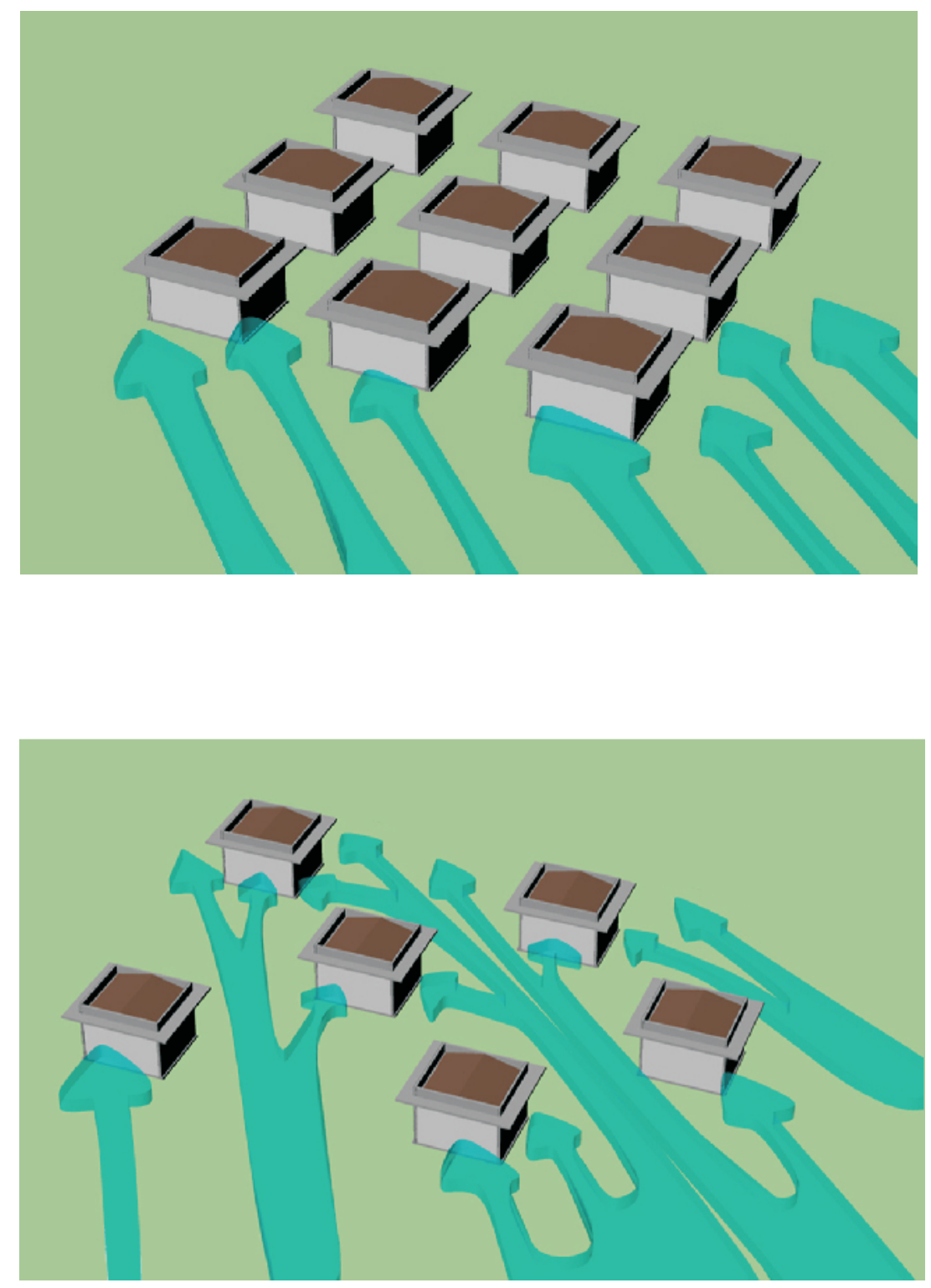

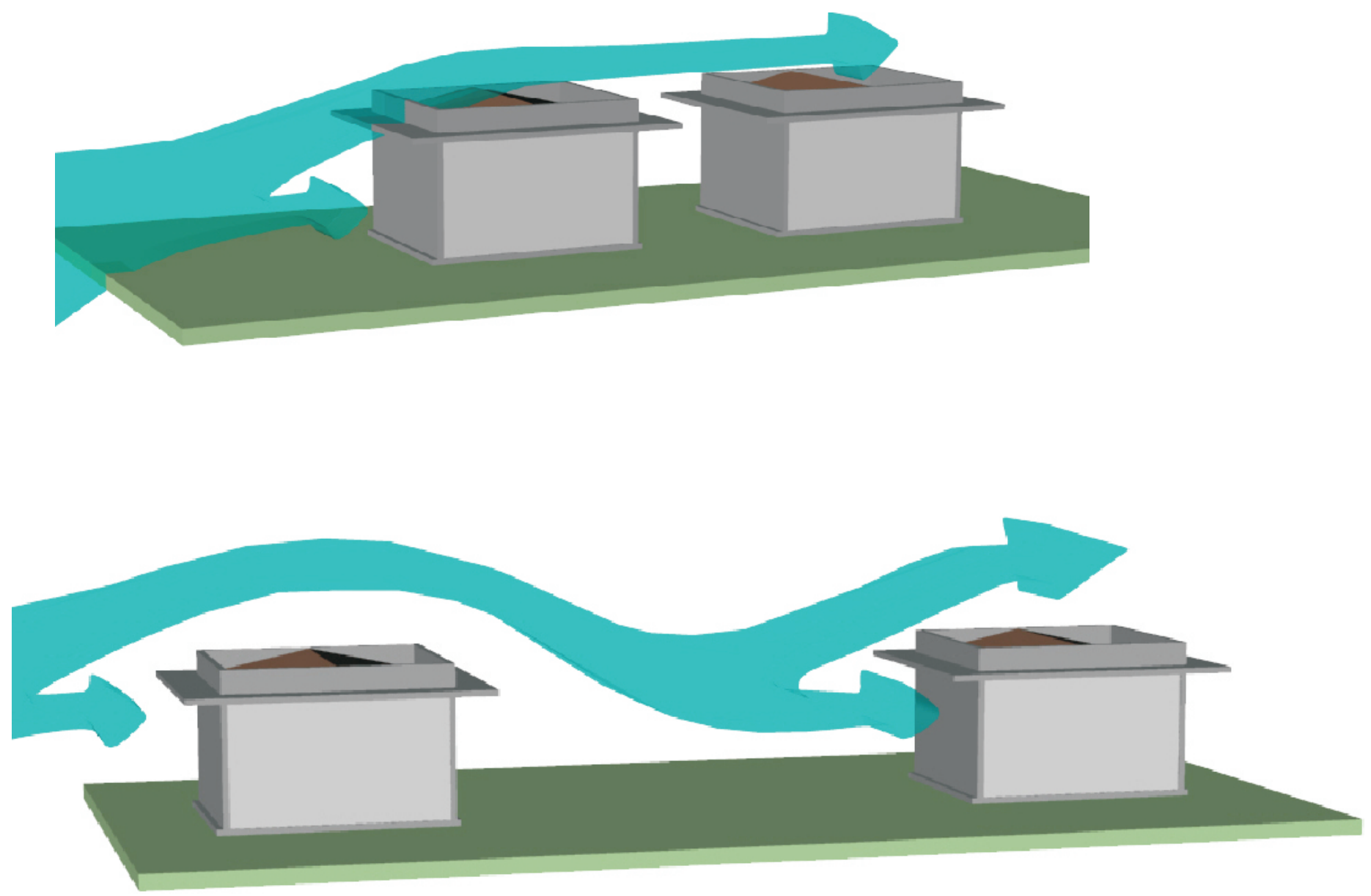


\subsection{ORIENTAÇÃO}

De maneira geral, indicam-se edificações alongadas com fachadas maiores voltadas para Norte e Sul, podendo haver ligeira variação para captação dos ventos dominantes. A fachada Sul é uma das que menos recebe incidência solar e fachada Norte não recebe incidência solar nos meses de verão. Nas outras estações do ano, quando ocorre incidência solar na fachada Norte, as proteções solares são simples de serem projetadas devido aos ângulos de incidência solar nesta orientação. Porém, podem ser adotadas outras orientações desde se preveja proteções solares e sombreamento para as fachadas sujeitas a uma incidência de radiação direta indesejável.

No capítulo anterior há o traçado solar para oito orientações na latitude de Ribeirão Preto e a classificação de fachadas segundo o ganho de calor por radiação no período da tarde. Estas ferramentas podem auxiliar na tomada de decisões em relação à implantação de edificações e na orientação de seus ambientes internos no sentido de minimizar sobreaquecimento decorrente da incidência de radiação direta em ambientes onde este fator seja indesejável. Cabe ressaltar que em alguns ambientes como dormitórios, apesar da questão do aquecimento, a incidência de radiação solar é desejável por 
Questões de salubridade devido à ação bactericida dos raios ultra-violeta. Nem sempre é possível dispor os ambientes para as orientações mais favoráveis. Assim, para se pensar a implantação deve-se ponderar com bom senso a incidência ou não de radiação solar em cada ambiente da edificação.

A orientação da edificação deve também levar em conta a ocupação dos ambientes internos. Ambientes de baixa permanência, como circulações, banheiros, depósitos, garagens podem estar dispostos em fachadas mais críticas. Já os ambientes de maior permanência e convívio seriam dispostos nas fachadas com menor incidência solar. Outra maneira é considerar os horários de ocupação de cada ambiente e relacioná-los com os horários de incidência solar de cada fachada, evitando que, durante a sua utilização, o ambiente esteja aquecido em demasia pela radiação direta. 


\subsection{ABERTURAS}

As aberturas devem ser dispostas nas fachadas levando-se em conta dois aspectos: a insolação e a ventilação. Em relação à insolação, deve-se orientar as aberturas de maneira a evitar a penetração de insolação nos ambientes internos, principalmente no período da tarde. No caso de necessidade em dispor aberturas em fachadas desfavoráveis, devem ser previstas proteções externas que reduzam a incidência solar sem prejudicar a ventilação (item 8.6.1). Em relação à ventilação, deve-se orientar as aberturas de acordo com a incidência dos ventos na edificação, para um correto posicionamento das aberturas de entrada e saída, e permitir a ventilação ao nível dos corpos. Para isto, não basta conhecer a direção predominante do vento. Cabe ao projetista detectar no local de implantação possíveis elementos como edificações próximas, árvores, acidentes topográficos que afetem a direção e velocidade dos ventos que atingirão o edifício. Nem sempre é necessário que as aberturas estejam posicionadas perpendicularmente à incidência dos ventos. Pode-se aproveitar a penetração dos ventos mesmo quando estes incidem obliquamente às aberturas de entrada. De um modo geral, para otimizar a velocidade do ar, as aberturas de saída devem ser maiores e mais altas que as de entrada.

Em Ribeirão Preto, há um fator favorável ao posicionamento de aberturas, que facilita a 

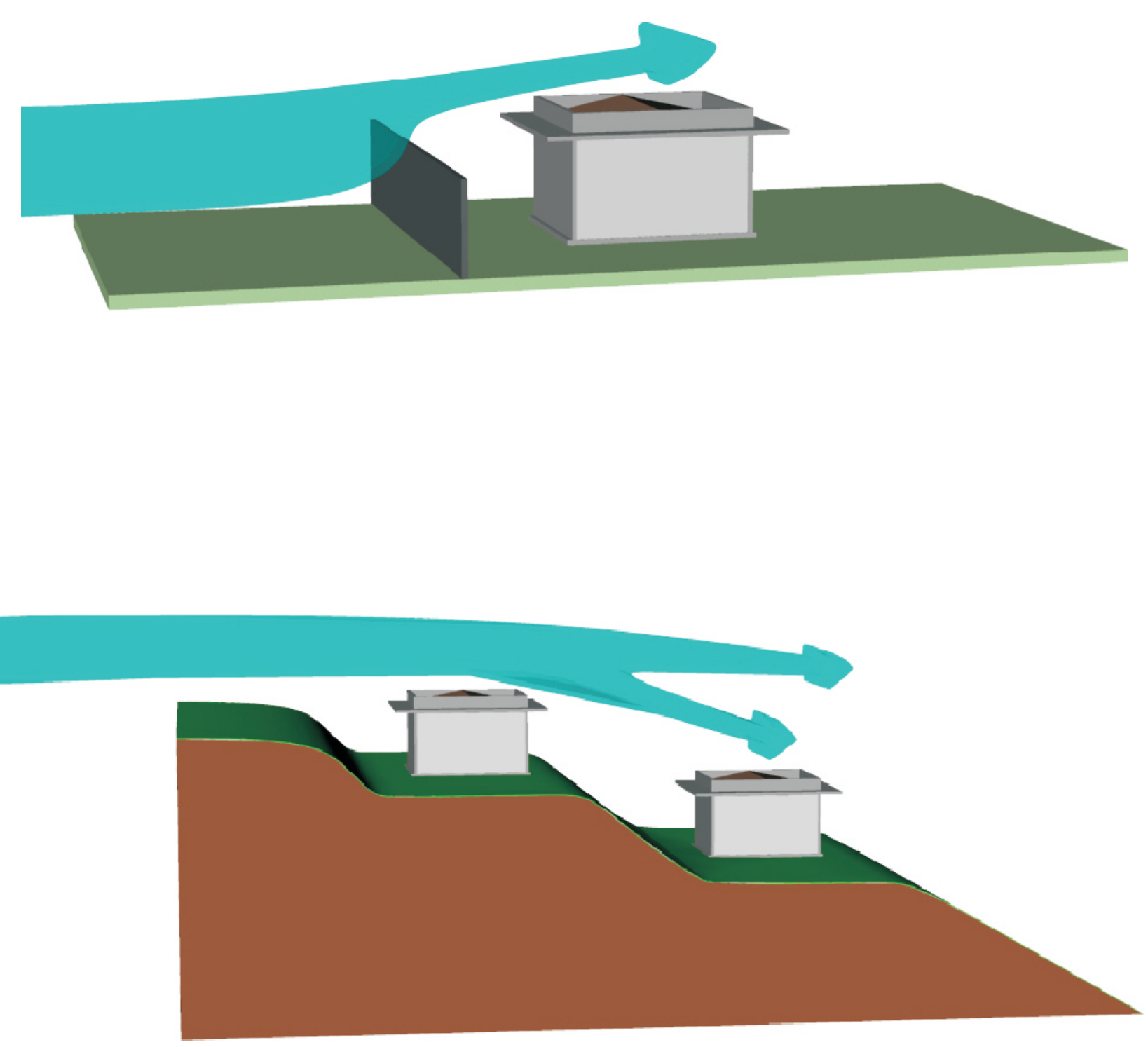

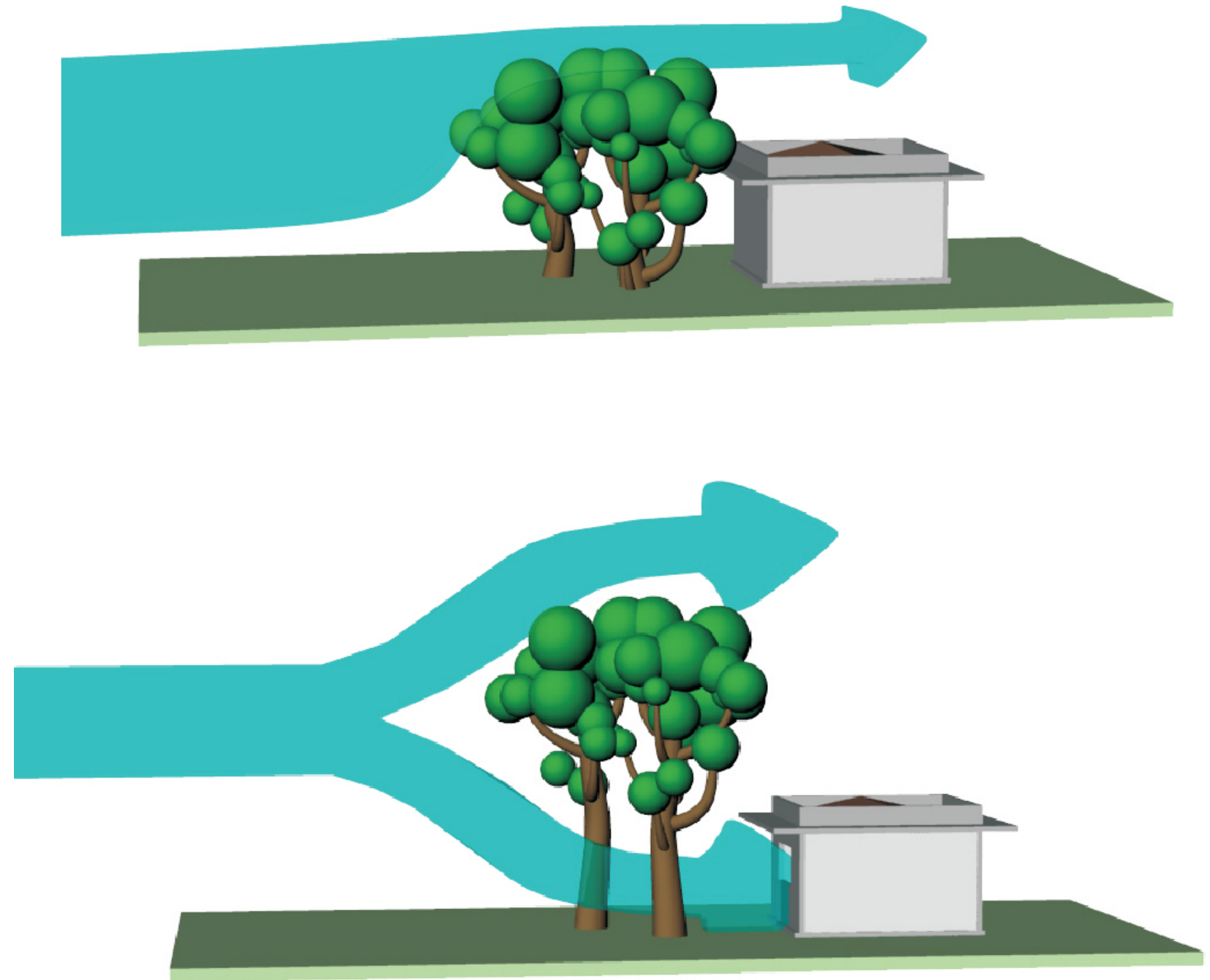
consideração concomitante da questão da insolação e dos ventos dominantes. As fachadas mais favoráveis do ponto de vista da ventilação, como a Leste, Sudeste e Sul, são também as mais favoráveis do ponto de vista da insolação. Porém, cabe ressaltar que devido à topografia da cidade, as áreas situadas na periferia do município contam com melhores condições de ventilação.

Quanto ao dimensionamento, as aberturas devem ter de $15 \%$ a $25 \%$ da área de piso do ambiente. Deve se atentar para o tipo de abertura do caixilho, levando-se em conta o tamanho de abertura efetiva, e não o seu tamanho total. Como exemplo, num caixilho com duas folhas, uma fixa e outra de correr, a área efetiva de ventilação será no máximo a metade de sua área total. Devido à variação das condições de umidade e temperatura no período quente, a ventilação pode ou não ser favorável ao conforto. Portanto, é desejável que o sistema de abertura dos caixilhos seja flexível, evitando a penetração de ventos quentes no período seco.

Para o efeito de ventilação cruzada, devem ser previstas ao menos duas aberturas no ambiente, para que uma funcione como entrada e outra como saída. Devem ser posicionadas em paredes distintas, de maneira que o percurso do ar entre uma abertura e outra percorra o máximo de área do 

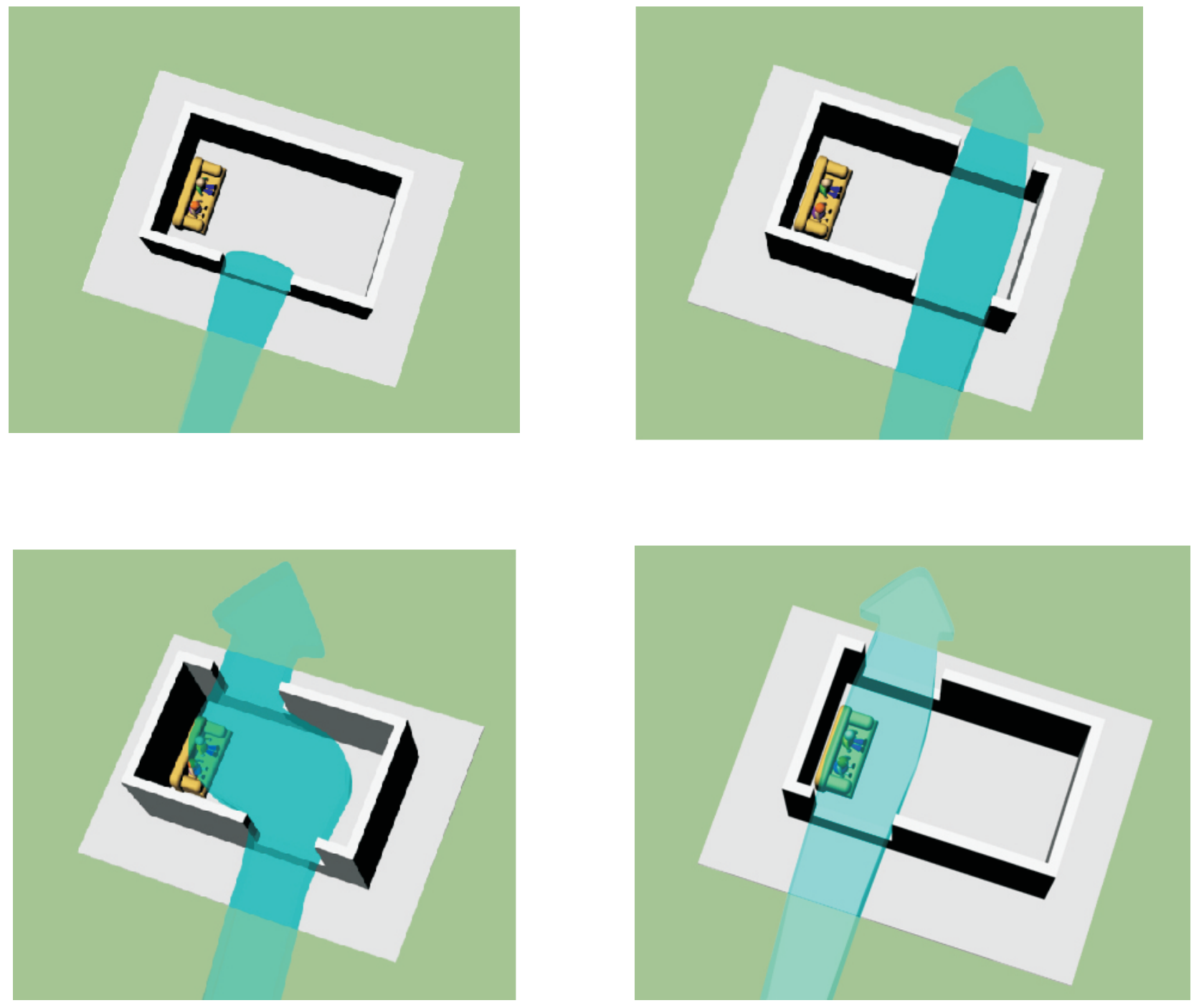
Ambiente. Nos ambientes que tiverem apenas uma abertura para o exterior, manter a porta aberta para que se crie um fluxo de ar.

Já para o efeito chaminé, é necessária uma diferença significativa de altura entre as aberturas de entrada e saída, sendo que quanto maior a diferença, mais eficiente é a circulação do ar. Os dois efeitos podem se dar de maneira conjugada com as mesmas aberturas.

A utilização de aberturas próximas ao forro também pode ser uma boa solução para retirada de calor do ambiente, pois evita que o ar quente acumulado no ambiente fique aprisionado próximo ao forro. 

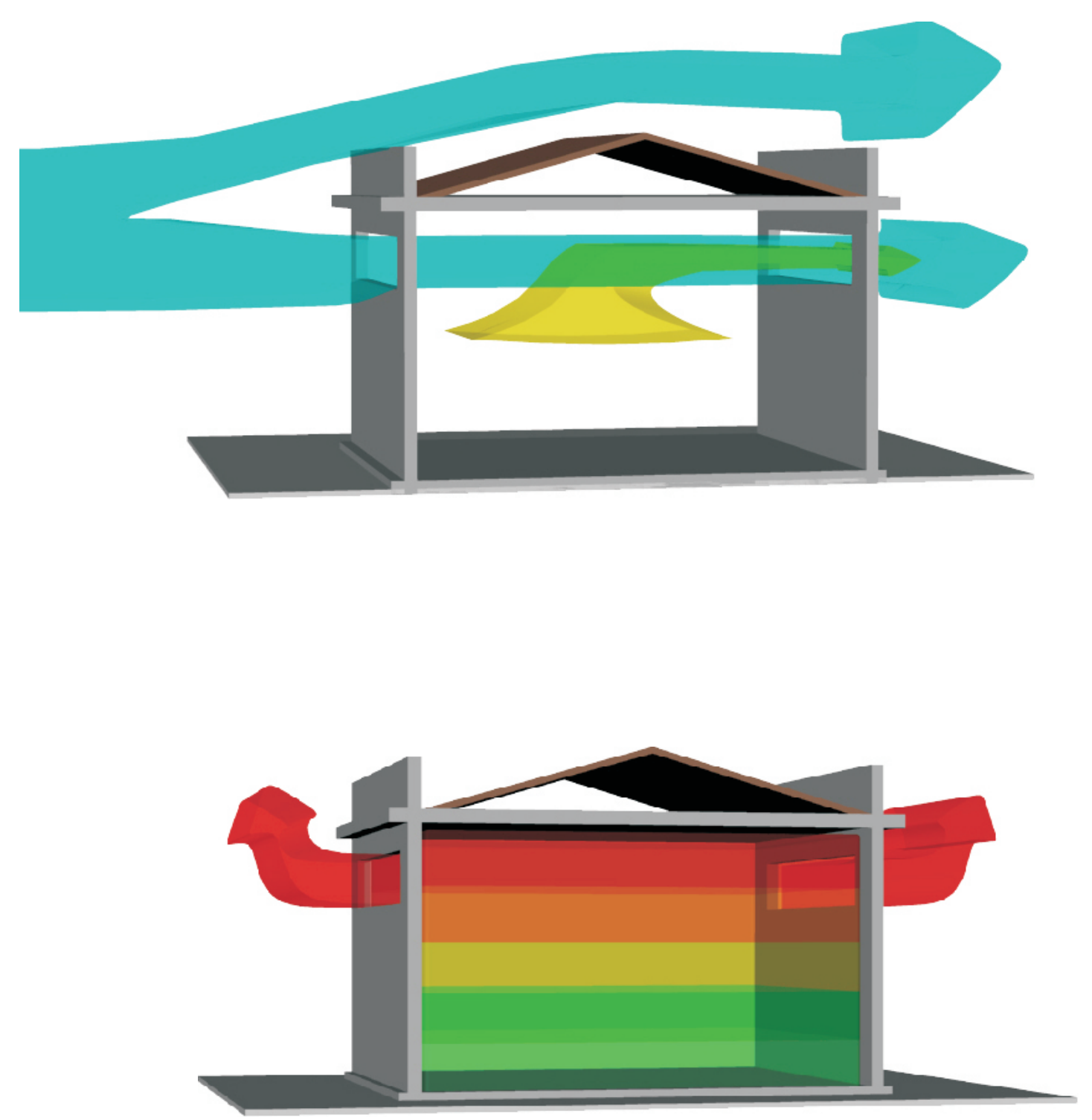


\subsection{VEDAÇÕES EXTERNAS}

No caso de edifícios de múltiplos pavimentos, as paredes são componentes de grande absorção de calor.

Deve-se atentar para a posição das paredes externas de modo que as fachadas de maior extensão recebam menor insolação. Quanto ao material as alvenarias duplas de tijolo cerâmico furado rebocada dos dois lados apresentam ótimo desempenho térmico. Porém esta tipologia pode ser inviável do ponto de vista econômico para muitas edificações. Alvenarias simples de tijolo cerâmico furado, rebocada dos dois lados apresentam desempenho térmico satisfatório, sendo em geral mais favoráveis ao conforto que as alvenarias com tijolos maciços no caso de Ribeirão Preto. As fachadas de uma mesma edificação apresentam conforto térmico distinto em função de sua orientação. Assim, podem ser utilizados materiais diferentes para cada fachada em função de sua orientação e influencia nos ambientes internos. Materiais com ótimo desempenho térmico mas de alto custo podem ser utilizados apenas nas fachadas mais críticas.

A cor da superfície externa das alvenarias é de extrema relevância para as condições de conforto dos ambientes internos, pois influencia 
significativamente na absorção de calor destas. De maneira geral, quanto mais clara a superfície menor a absorção de calor. Assim, para Ribeirão recomenda-se a utilização de cores claras nas superfícies externas das paredes, principalmente nas fachadas com maior incidência solar.

A previsão de sombreamento através da utilização de vegetação ou proteções solares nas paredes mais expostas à radiação é uma boa estratégia para a redução do ganho de calor pelas paredes.

No caso de edificações baixas, a cobertura tem maior relevância que as paredes na absorção de calor pela edificação, devido ao seu posicionamento próximo ao plano horizontal.

Quanto ao material, de maneira geral podem ser utilizadas telhas cerâmicas, de concreto, metálicas ou de fibrocimento. Vale lembrar que por absorverem agua, as telhas cerâmicas tendem a escurecer com o tempo, aumentando a absorção de radiação e prejudicando o seu desempenho térmico.Mas independentemente do material, devem ser de cores claras ou receberem pintura na cor branca ou semelhante. Se houver a presença de ático e forro em laje mista, a influencia do material da telha no conforto do ambiente fica reduzida. 


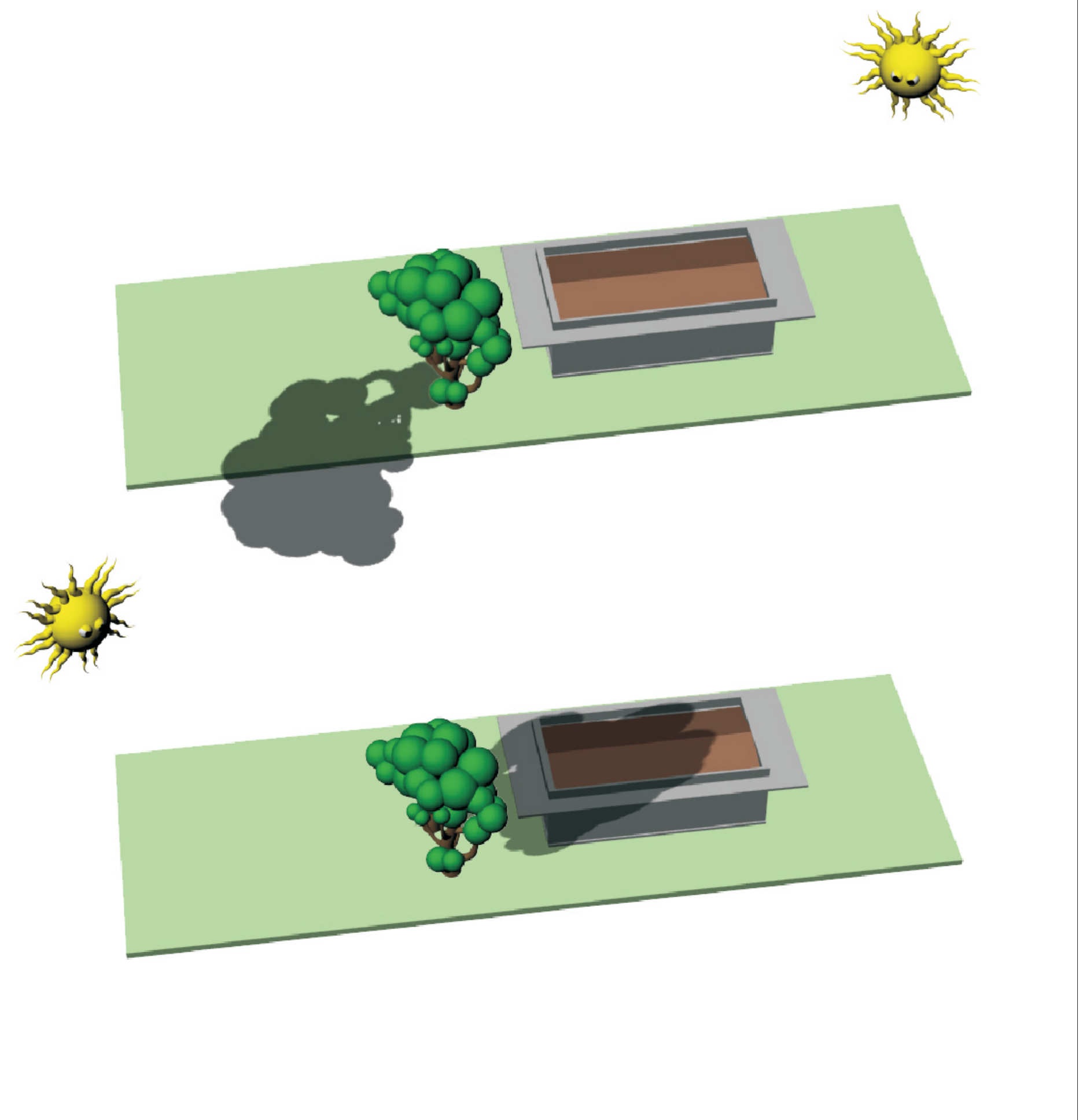


A utilização de lâminas de alumínio entre telhado e forro de madeira ou laje aumenta o atraso térmico do conjunto, retardando o fluxo de calor do exterior para o interior durante o dia e do interior para o exterior durante a noite. Portanto deve-se avaliar se esta propriedade é favorável em função do tipo de ocupação da edificação.

Um sistema de cobertura que tem se mostrado favorável ao conforto térmico em climas quentes é a cobertura verde. A presença de vegetação na cobertura resulta num grande atraso térmico, contribuindo para um menor aquecimento dos ambientes internos. Cabe ressaltar que, para o bom funcionamento deste sistema, deve-se respeitar as especificações técnicas contidas nas pesquisas existentes sobre o assunto assim como prever um sistema fácil de manutenção da vegetação.

Além da utilização de materiais e cores adequadas, alguns recursos podem influenciar positivamente no desempenho térmico das coberturas em Ribeirão Preto. A utilização do ático ventilado permite a circulação de ar no espaço entre forro e cobertura ajuda a reduzir o aquecimento do ambiente durante o dia e auxilia na retirada de calor do ambiente durante a noite. $\mathrm{O}$ sombreamento da cobertura é extremamente favorável ao conforto. 

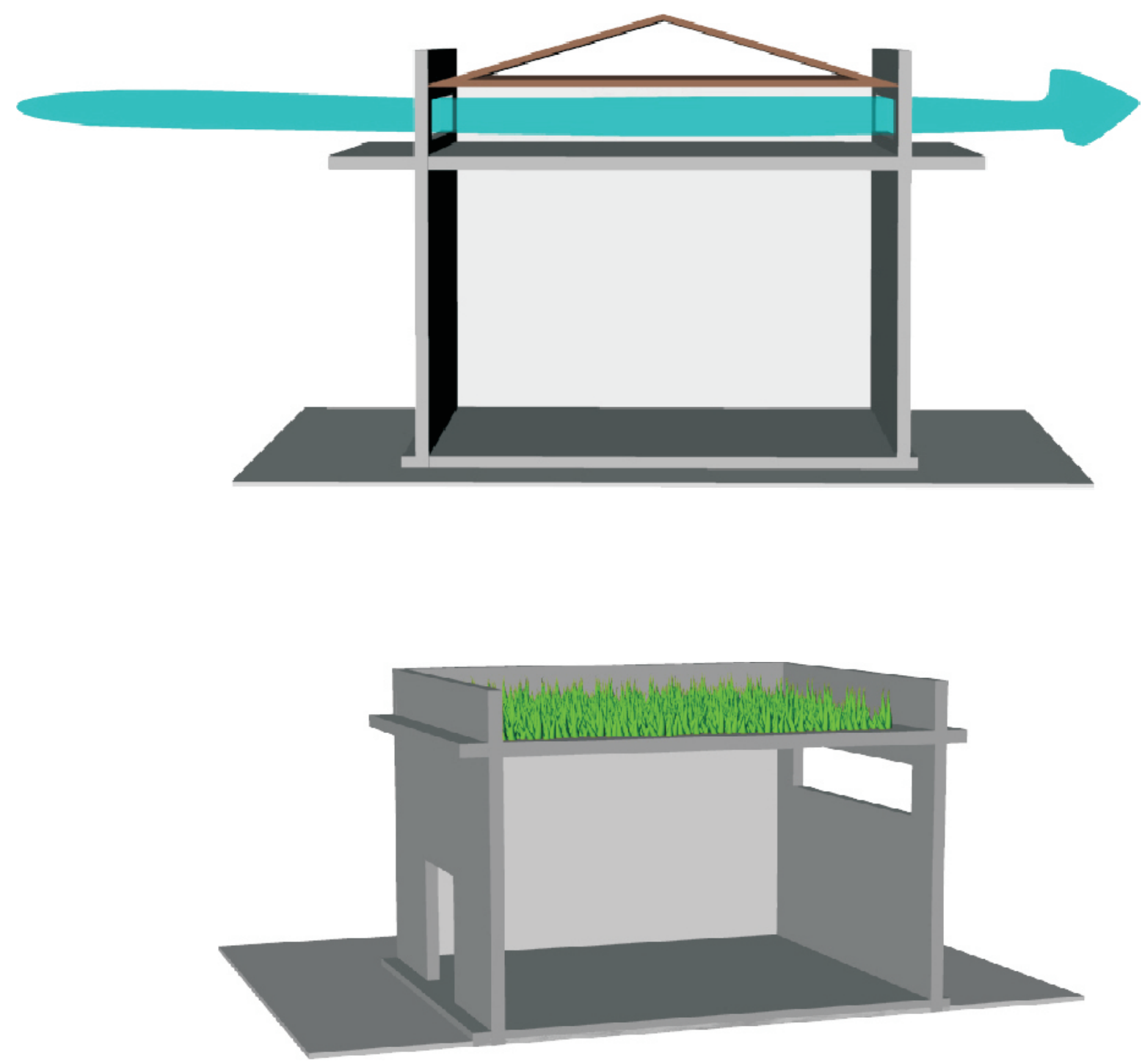
Este sombreamento pode se dar através de vegetações de grande porte ou através de sobre-coberturas.

Superfícies envidraçadas e transparentes devem ser sombreadas em qualquer orientação onde haja incidência solar direta. Este sombreamento deve se dar a partir de elementos externos, de maneira a minimizar a incidência solar nas superfícies transparentes. Proteções internas não são tão eficientes, pois permitem que os raios solares atravessem a superfície transparente e penetrem no ambiente interno. Ao contrário do que se acredita as películas para vidros não podem ser consideradas como proteções eficientes do ponto de vista térmico. A maioria das películas existentes conseguem barrar uma pequena parcela dos raios infra-vermelhos, que dentro do espectro solar são os responsáveis pelo calor, e portanto não impedem a entrada de calor através das superfícies envidraçadas. Apesar de ser muitas vezes prejudicial ao conforto térmico, a utilização de superfícies transparentes em edificações cria ambientes visualmente agradáveis além de atender a necessidades de iluminação. Portanto, recomenda-se que a utilização destas esteja atenta a uma proporção razoável entre áreas opacas e transparentes. A utilização de superfícies transparentes em coberturas não é recomendada para Ribeirão Preto. 


\subsection{TRATAMENTO DO ENTORNO}

As superfícies do entorno têm a propriedade de absorver parte da radiação solar e então reemitir ao meio e à edificação na forma de radiação de ondas longas, contribuindo para seu aquecimento durante o dia. Assim, o grau de refletância das superfícies próximas à edificação influencia diretamente no ganho de calor desta, além de influenciar nas temperaturas do micro clima local.

No caso de superfícies com vegetação, a absorção de radiação é alta, mas a reemissão é baixa, se comparada a superfícies pavimentadas. Assim, recomenda-se tratar o entorno da edificação de maneira a manter ou criar o máximo possível de áreas verdes e que estas áreas sejam bem ventiladas, no sentido de minimizar o ganho de calor na edificação e o aumento de temperatura do microclima local. A utilização de vegetação de grande porte para a criação de áreas sombreadas é extremamente favorável. 
$\pi$

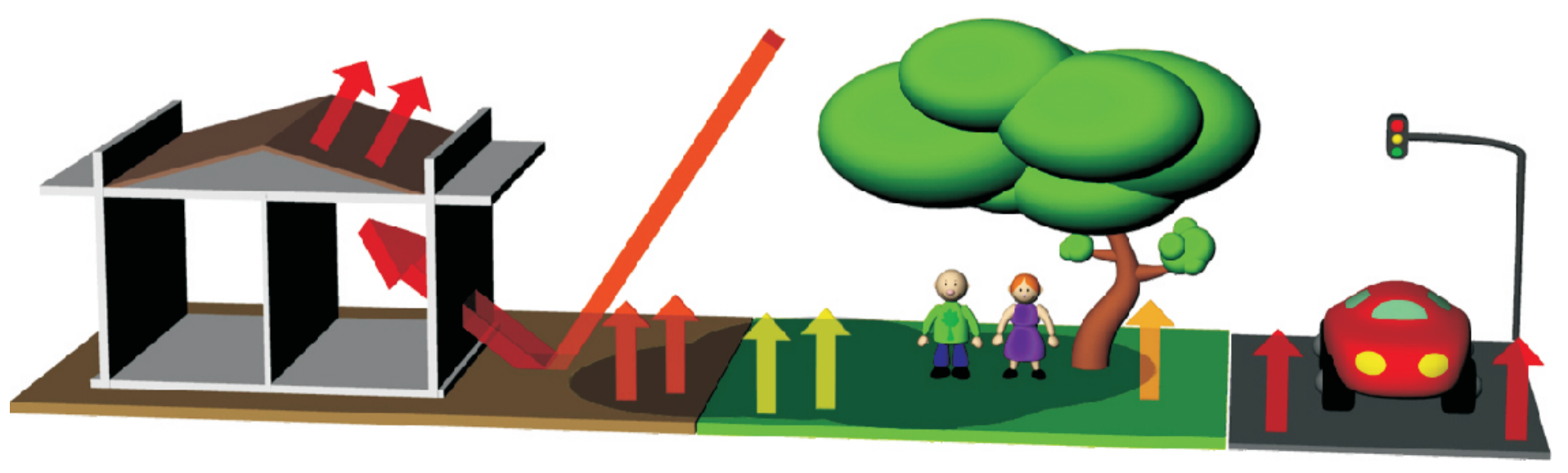




\subsection{ESTRATÉGIAS DE CONDICIONAMENTO TÉRMICO PASSIVO}

No caso de Ribeirão Preto, dentre as recomendações e estratégias estudadas, pode-se considerar a proteção à radiação como principal estratégia de condicionamento térmico passivo, pois além de ser favorável durante todo o ano, sua eficiência não é afetada por variações climáticas e elementos externos e internos. A proteção de uma edificação em relação à radiação envolve um conjunto de aspectos. Além dos conceitos já vistos nos itens anteriores, como orientação das fachadas, tratamento da cobertura e tratamento do entorno, podem ser utilizados elementos de proteção para fachadas e aberturas que minimizem a incidência de radiação direta através do sombreamento destes. Cabe ressaltar que as proteções devem ser sempre externas, de maneira a impedir que a radiação atinja as superfícies.

As proteções podem se dar na forma de elementos construtivos já conhecidos como beirais e marquises prolongados, varandas, elementos vazados, empenas e muros, brises, pergolados, entre outros. Mas a possibilidade de proteções solares é infinita e podendo apresentar soluções inusitadas de acordo com o exercício criativo do projetista.

A utilização da vegetação como proteção solar, através de elementos já 
existentes no terreno ou do planejamento paisagístico, é extremamente favorável ao conforto térmico. Além de sombrear as superfícies ou aberturas desejadas, sombreia também o entorno da edificação melhorando as condições de seu microclima.

A aplicação dos elementos de proteção solar depende da orientação da superfície a ser protegida. Alguns dependem de métodos geométricos específicos de desenho que não são tratados neste trabalho. Mas, de maneira geral deve-se considerar a altura e os ângulos horizontais de incidência solar na fachada que se pretende proteger, de acordo com os traçados do capítulo 7 deste trabalho. Em fachadas como a Norte, onde a radiação incide com uma altura solar maior, a proteção pode se dar através de simples beiral ou marquise. Já em fachadas onde a altura solar é menor, como a Oeste, as proteções devem estar dispostas como anteparos entre a posição do sol e a superfície, sem que isto impeça a circulação de ar nesta superfície.

A ventilação natural é uma importante estratégia de condicionamento térmico passivo quando aliada a certas condições de umidade e temperatura. No caso de Ribeirão Preto, a ventilação natural tem maior contribuição para a 


$$
\text { هو }
$$


redução de temperaturas dos ambientes e melhora na sensação térmica do indivíduo nos meses quentes e úmidos. Já nos meses com baixa umidade relativa, a ventilação natural pode ser desfavorável ao conforto térmico. Devido à baixa umidade e altas temperaturas, frequentemente nesta época os ventos no período da tarde trazem uma temperatura maior do que a dos ambientes internos, além de estarem carregados de poeira. Porém, vale ressaltar que ventilar significa também introduzir no interior do edifício as condições exteriores. Como durante a noite as temperaturas internas geralmente são superiores às externas, mesmo nos meses secos a ventilação teria efeito refrescante, retirando calor do interior no período noturno.

Deve ainda se considerar que as condições topográficas de Ribeirão Preto prejudicam a incidência dos ventos em algumas partes da sua área urbana.

Uma estratégia favorável no período quente e seco é o resfriamento evaporativo, que consiste na umidificação do ar, sendo que as partículas de água absorvem o calor e evaporam, diminuindo a temperatura do ar. Essa umidificação pode se dar através fontes, aspersores e espelhos d'água além de aparelhos mecânicos existentes no mercado. 
6. CONSIDERAÇÕES FINAIS 
$\mathrm{Na}$ maioria das vezes, falhas de projeto em relação ao conforto térmico podem ser evitadas nas primeiras decisões dentro do processo de projeto. Portanto, ainda que gerais, as recomendações deste manual certamente contribuem para melhores condições de conforto térmico em edificações na cidade de Ribeirão Preto.

A proteção à radiação configura-se como a principal estratégia de condicionamento passivo para as edificações da cidade. Assim, o traçado dos ângulos deste manual possibilita melhor compreensão da trajetória solar na latitude de Ribeirão Preto além de facilitar o projeto de proteções solares para os espaços construídos. Além disto, a classificação de fachadas também pode auxiliar na tomada de decisões em relação à implantação.

Espera-se que este manual se configure como uma ferramenta aliada aos profissionais e auxilie na incorporação dos conceitos de condicionamento térmico natural nos projetos de edificações na cidade. 
7. REFERENCIAS BIBLIOGRAFICAS 